UNIVERSIDADE DE SÃO PAULO - INSTITUTO DE GEOCIENCIAS CURSO DE PÓS GRADUAÇÃO - NIVEL DE DOUTORAMENTO

ANALISE DOS FATORES QUE ATUAM NO AQÜIFERO FISSURAL.

-ÁREA PILOTO dOS ESTAdos DA PARAIBA E R.G. DO NORTE-

Tese apresentada pelo geólogo WALDIR DUARTE COSTA para obten ção do tîtulo de Doutor em Geo ciências, Ârea de Geologia Ge ral e de Aplicação, sob a or $\underline{i}$ tação do Prof. Dr. ALDO DA CU NHA REBOUÇAS

DEDALUS - Acervo - IGC

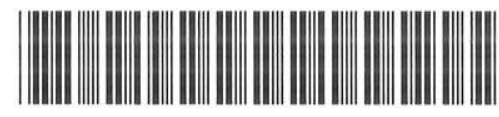

30900006045

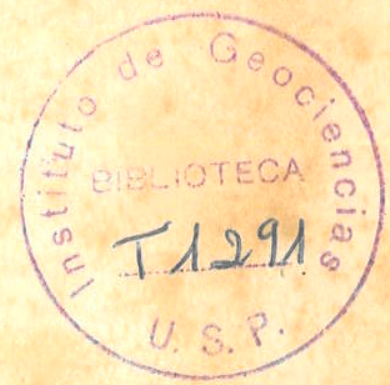

SÃO PAULO - 1986 
Aos meus pais,

João e Zilda

A minha esposa,

Ciçone

Aos meus filhos,

Ana Cristina

Ciçone

Waldir

Orlando

Luciano 
CAPITULO 1: INTRODUCAAO

1.1. APRESENTACAO

1.2. OBJETIVO E FINALIDADE

1.3. METODOLOGIA DA PESQUISA

1.4. AGRADECIMENTOS

- PARTE 1: C O N C E I T O S F U N D A M E N T A I S

CAPITULO 2: FATORES QUE ATUAM NO AQÜIFERO FISSURAL

2.1. INTRODUCAOA

2.2. FATORES EXOGENOS

2.2.1. CLIMA

2.2 .2 . RELEVO

2.2 .3 . HIDROGRAFIA

2.2 .4 . VEGETAÇAO

2.2.5. INFILTRACÃO E ASCENCAOO DE SOLUCOES

2.2.6. COBERTURAS SEDIMENTARES

2.3. FATORES ENDOGENOS

2.3.1. ESTRUTURAS GEOLOGICAS E MECÃNICA DAS ROCHAS

2.3.2. UTILIZAÇAO DOS PARÂMETROS LITO-ESTRUTURAIS NA LOCACAO dO pOCOO

CAPITULO 3: DINÂMICA DO FLUXO EM FRATURAS

3.1. INTRODUCAO

3.2. CONCEITOS HIDRAULICOS FUNDAMENTAIS

3.2.1. REGIMES DE ESCOAMENTO

3.2.2. LEI DE DARCY - LIMITE DE VALIDADE

3.3. CARACTERISTICAS GEOMETRICAS DO MEIO FISSURADO

3.3.1. COMPORTAMENTO HIDROGEOLOGICO DO MEIO

3.3.2. A FISSURA ELEMENTAR

3.3.3. O MEIO FISSURADO

3.3.4. O AQUIFERO FISSURAL

- PARTE 2: A $\bar{A}$ R E A P I l O T 0

CAPTTULO 4: CARACTERIZACÃO FISIOGRÄFICA REGIONAL 
4.2.1. ELEMENTOS DO CLIMA 72

4.2.2. CIRCULAÇÃO ATMOSFERICA 73

4.2 .3 . PLUVIOMETRIA

4.2.4. TEMPERATURA 77

4.2.5. EVAPOTRANSPIRACAO POTENCIAL E REAL 80

4.2 .6 . UMIDADE RELATIVA 80

4.2 .7 . BALANCO HIDRICO 82

4.2.8. CLASSIFICACOES CLIMÃTICAS 85

4.3. RELEVO E GEOMORFOLOGIA 86

4.4. HIDROGRAFIA 91

4.5. SOLO E VEGETACAO 91

CAPITULO 5: GEOLOGIA E GEOTECTÔNICA DA ÃREA

5.1. INTRODUÇAOO 95

5.2. COMPARTIMENTACAO GEOTECTONICA DA PROVINCIA BORBOREMA 95

5.2.1. LIMITES DA PROVINCIA: OS CRATONS 96

5.2 .2 . OS DOMINIOS GEOTECTONNICOS 98

5.2 .3 . SISTEMAS DE DOBRAMENTO E MACICOS 100

5.2.4. FALHAMENTOS E LINEAMENTOS REGIONAIS 103

5.3. O DOMINIO EXTREMO NORDESTE OU CENTRO-ORIENTAL 106

5.3.1. MACIÇO CALDAS BRANDAO-SAO JOSE DO CAMPESTRE 106

5.3.2. MACIÇO PERNAMBUCO-ALAGOAS 107

5.3.3. SISTEMA DE DOBRAMENTOS PAJEU-PARAIBA 108

5.4. O DOMINIO TRANSNORDESTINO OU CENTRAL 109

5.4.1. SISTEMA DE DOBRAMENTO SERIDO 109

5.4.2. SISTEMA DE DOBRAMENTO PIANCO-ALTO BRIGIDA 111

5.4.3. SISTEMA DE DOBRAMENTO RIACHO DO PONTAL 111

5.5 . O DOMINIO CEARENSE OU JAGUARIBEANO 112

5.5.1. MACICO SANTA QUITERIA 113

5.5.2. MACICO TROIA-TAUA 113

5.5.3. MACICO RIO PIRANHAS 113

5.5.4. OS SISTEMAS DE DOBRAMENTOS VESTIGIAIS 114

- PARTE 3: E S T U D O S R E A L I Z A D O S

CAP TTULO 6: CADASTRAMENTO DOS POCOS DA REGIAOO

6.1. CONSIDERACOES GERAIS 
6.2. ZONEAMENTO DOS POCOS NA ÄREA ESTUDADA

6.3. ANALISE DOS ELEMENTOS DO CADASTRO DE POCOS

6.3 .1 . TIPO DE ROCHA

121

6.3 .2 . MANTO DE COBERTURA

121

6.3 .3 . FRATURAS

126

6.3 .4 . RELEVO/HIDROGRAFIA

126

6.3 .5 . RESTDUO SECO

127

6.3 .6 . PROFUNDIDADE DO POÇO

128

6.3.7. NIVEL ESTATICO

130

6.3 .8 . NIVEL DINÂMICO

131

6.3 .9$. VAZAO

131

6.3.10. VAZXO ESPECTFICA

CAP ITULO 7: RELACIONAMENTO ENTRE PARĀMETROS DE POCOS E FATORES ATUANTES

7.1. INTRODUÇOAO

7.2. RELACOES ENTRE OS PARAMMETROS DO POCO E OS FATORES INTRTNSECOS E EXTRTNSECOS

7.2.1. RELACAO VAZAO ESPECIFICA X RESIDUO SECO 136

7.2.2. RELAÇAO VAZAO ESPECIFICA X TIPO DE ROCHA 141

7.2.3. RELACAO VAZAO ESPECIFICA $X$ TIPO DE FRATURA

7.2.4. RELACAO VAZAO ESPECIFICA X PROFUNDIDADE DO POCO

7.2.5. RELACAO VAZAO ESPECIFICA X ENTRADA D'ÄGUA 154

7.2.6. RELACXO VAZAO ESPECTIICA X MANTO DE COBERTURA 160

7.2.7. RELACAO VAZAO ESPECTFTCA X RELEVO/HIDROGRAFIA 166

7.2.8. RELACAO VAZAO ESPECTFICA X CLIMA 169

7.2.9. RELACAO RESIDUO SECO $X$ TIPO DE ROCHA 170

7.2 .10 .. RELACAO RESTDUO SECO X TIPO DE FRATURA 173

7.2.11. RELACAO RESTDUO SECO $X$ ENTRADA D'ÁGUA

7.2.12. RELACAO RESIDUO SECO $X$ PROFUNDIDADE DO POCO

7.2.13. RELACAOO RESIDUO SECO X MANTO DE COBERTURA

7.2.14. RELAÇAO RESIDUO SECO X RELEVO/HIDROGRAFIA

7.2.15. RELACAO RESTDUO SECO X CLIMA

CAPITULO 8: A LOCACAO DO POCO A LUZ DOS NOVOS CONHECIMENTOS - ZONEAMENTO HIDROQUIMICO PARA A ÁREA PILOTO 
8.2. ZONEAMENTO HIDROQUTMICO

8.2.1. CONSIDERAÇOES GERAIS 196

8.2.2. CONSIDERACOES SOBRE OS RESULTADOS OBTIDOS 197

8.2.3. CONCLUSOES GERAIS SOBRE O ESTUDO HIDROQUIMICO 199

$-A N E X O S$

A-1 - BIBLIOGRAFIA CONSULTADA

A-2 - CADASTRO DOS pOCOS

A-3 - MAPA GEOLOGICO DA AREA

A-4 - ZONEAMENTO HIDROQUIMICO 
CAP ITULO 1

HNTROHUÇAOO 
A região semi-ärida do nordesde do Brasil sofre secú larmente o angustiante problema da seca, mercê de seu clima, on de a evaporação ultrapassa a precipitação. O regime pluviométri co é torrencial, com distribuição extremamente irregular das pre cipitações em poucos meses do ano, o que redunda em regime flu vial com escoamento restrito aos períodos chuvosos.

Esse quadro de deficiência hídrica superficial, ê so bretudo acentuado nos domínios de ocorrência das rochas metamōr ficas e magmaticas, de idade precambriana, desprovidas de impor tantes mantos de alteração e cobrindo cerca de $450.000 \mathrm{~km}^{2}$.

As rochas sedimentares, com melhores condições aquífe ras, abrangem uma ärea equivalente, compreendendo a bacia do Parnaiba, no Piaui $\left(500.000 \mathrm{~km}^{2}\right)$, a bacia do Jacarë/Salitre na Bahia $\left(70.000 \mathrm{~km}^{2}\right)$, bacias costeiras de Apodi,R.G.do Norte (com $\left.20.000 \mathrm{~km}^{2}\right)$, Pernambuco/Paraiba $\left(13.000 \mathrm{~km}^{2}\right)$ e Alagoas/Sergipe $\left(12.000 \mathrm{~km}^{2}\right)$, alēm das bacias intracratônicas de Recôncavo/Tuca no/Jatoba $\left(56.000 \mathrm{~km}^{2}\right)$. Outras pequenas bacias sedimentares in tracontinentais de pequenas dimensões, ocorrem na região, como a Chapada do Araripe (PE/CE), Bacia do Rio do Peixe(PB), Bacias Iguatu-Icó(CE), dentre outras, que somadas chegam a casa dos $25.000 \mathrm{~km}^{2}$. (Ver Fig. 1.1)

Alëm do problema representado pela precária infiltra cão e armazenamento, ocorre paralelamente um outro, que è a ele vada salinização das äguas subterrâneas acumuladas nas zonas a quíferas das rochas que compõem o substrato geolögico precambri ano da região semi-ärida do Nordeste.

o comportamento hidrogeologico das rochas duras fratu radas, denominadas pelo autor, de aquifero fissura1 (COSTA,1980) $\vec{e}$ bastante complexo na região nordestina, e os poços ali perfu dos, cerca de 50.000 , apresentam os mais variados resultados.

Destacam-se, com efeito, o elevado nümero de poços se $\cos$ (cerca de $40 \%$ ), a pequena vazão mëdia obtida de aproximada mente $2.5001 / \mathrm{h}$ e o elevado resíduo seco cuja mëdia é de 3.000 $\mathrm{mg} / 1$. Não obstante, ocorrem situações muito favoräveis, as quais 
constituem estímulo à perfuração de poços nessa região.

Esta situação decorre de muitos fatores, destacando-se as locações aleatōrias, quer por ausência de têcnicos qualifica dos nas empresas de perfuração que atuam na area, quer pela in gerência dos proprietärios no processo da locação do poço, ou ainda pelas improvisacões impostas pelos planos de emergância ou das tristemente famosas "operação paliteiro".

o conhecimento da problemätica do cristalino aumenta muito as chances de obtenção de bons resultados, a partir de 10 cações tecnicamente bem conduzidas, conforme tem demonstrado a prätica.

No presente trabalho, buscou-se estabelecer os melhores critërios de locação de um poço, a partir de uma anälise dos di versos fatores que atuam na hidrogeologia do aquifero fissural. para que pudesse ser bem entendido o problema, iniciou-se o es tudo pela análise dos fatores físio-climäticos regionais, passan do-se ao mecanismo de origem tectônico e lito-estrutural de ge ração das zonas aquíferas. A dinâmica dos fluxos da ägua em fra turas foi analisada, compreendendo os aspectos morfológicos e de comportamento do flüido.

\subsection{OBJETIVO E FINALIDADE}

Conforme ficou caracterizado na apresentação, o traba Iho tem por objetivo primordial, analisar os fatores que atuam no comportamento hidrogeológico do aquifero fissural, a forma de atuação de cada fator, o grau de participação dos mesmos e portanto, a importância desempenhada por cada um, tanto na quan tidade como na qualidade das äguas armazenadas nesse aquífero.

A finalidade de se conhecer o mecanismo hidrogeológico desse heterogêneo e anisotrópicomeio, $\vec{e}$ a de se obter melhores vazões e águas de mais baixos teores de salinidade, a partir de locações de poços tecnicamente bem executadas e, com esse proce dimento, minorar o angustiante problema da dessedentação do po vo e animais habitantes da inóspita região semi-ärida do nordes te brasileiro. 
A pesquisa desenvolvida foi iniciada com uma rigorosa a nâlise dos dados de poços de toda a região semi-ärida cristalina do Nordeste, a fim de selecionar uma ärea piloto, em função dos graus de distribuição e de confiabilidade desses dados. Por outro lado, evitou-se estender a análise à toda a região, para não se incorrer em generalizaçöes, incompatíveis com os níveis de conple xidade das condições de ocorrência das äguas subterrâneas neste tipo de aquifero e com a baixa qualidade das informações disponí veis.

Desta forma, a ärea de estudo ficou reduzida aos Estados do Rio Grande do Norte e Paraiba. A ärea total desses dois Esta dos, perfaz $109.387 \mathrm{~km}^{2}$, todavia, descontando-se $28.020 \mathrm{~km}^{2}$, re lativos às äreas cobertas pelas bacias sedimentares costeiras (ao norte e leste) e coberturas sedimentares localizadas, resta a $\underline{a}$ rea de $81.367 \mathrm{~km}^{2}$, na qual foram localizados os poços cadastra dos. Conforme pode ser visto na Fig.1.1, a área é delimitada pe las coordenadas geogräficas $35900^{\prime}$ a $38930^{\prime}$ Long.W.Gr. e 5930'a $8900^{\prime}$ Lat.Sul.

A essa fase, seguiu-se uma anälise de cada elemento do poço e dos fatores que atuam sobre o mesmo. Durante os trabalhos dessa fase, foram efetuadas viagens ao campo, para esclarecer os pontos de düvida, observar a precisa localização do poço e as condições locais de geologia, principalmente, o tipo litico e as estruturas. Foi tambëm desenvolvido um estudo de fotointerpreta são geolögica para detectar as macroestruturas desenvolvidas, 1o cal e regionalmente, em torno dos pontos d'ägua analisados.

A etapa final, foi o estudo da participação de cada um dos fatores, na vazão especiffica e no resïduo seco apresentado por cada poço, a fim de avaliar o nível de participação ou influ ência desses fatores. Nesse estudo, foram elaborados gráficos de funções e anälise de tabelas com parâmetros estatísticos, bem co mo, examinado o Indice de correlação entre as variâveis analisa das, a partir de um programa de regressão. Ao final, são apresen tados os graus de relacionamento dos fatores exógenos e endógenos e as conclusões acerca da problemätica de poço no aquífero fissu ral. 
Dessa maneira, o presente texto compreende 3 (três) par tes distintas, embora que interrelacionadas no contexto geral da

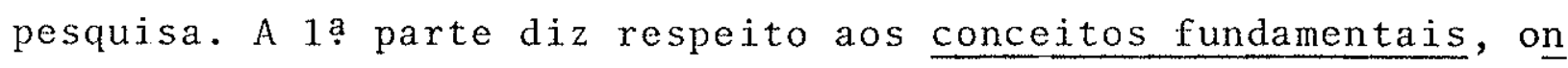
de são descritos os fatores que atuam no aquifero fissural e a forma de atuação, alëm de um capítulo acerca da dinâmica do $f \underline{u}$ xo no meio fissurado. Essa primeira parte é importante para $f \underline{i}$ xar as premissas bảsicas do estudo realizado. Na 2 a parte, são apresentadas as características fisiogräficas e geolögicas da á rea piloto, escolhida para desenvolvimento dos estudos propria mente ditos. Essa caracterização é imprescindivel para bem enten der o relacionamento dos fatores exógenos e endógenos. Finalmen te a 3a parte, corresponde aos estudos realizados, com uma sínte se conclusiva ao final.

Para uma pesquisa mais profunda, seria necessärio, a disponibilidade de verbas para execução de poços de pesquisa, Io cados segundo os mais rigorosos critérios técnicos, nas mais di ferentes situações litolögicas, estruturais e de outros condicio nantes. Isso implicaria num total de pelo menos 50 poços, o que representaria um custo muito elevado, incompativel com a realida de da política de desenvolvimento cientifico e tecnológico bras leira.

A pesquisa foi então realizada a partir de dados existen tes e que refletem os aspectos de locação do poço, apesar da in fluência externa de ordem estrutura1, política de programas, no processo de locação do poço, o que redundou numa margem de insu cesso em torno de $40 \%$.

Uma outra condição que deve ser cuidadosamente analisa da, $\vec{e}$ o uso de dados estatísticos para estabelecer correlação en tre variäveis pesquisadas. A estatística $\vec{e}$ uma importante ferra menta de traba1ho, mas a fiel interpretação dos dados, ou crítí ca dos resultados, deve ser sempre empregada a fim de verificar a correta utilização desse mëtodo. Assim é que, duas variäveis que se procura correlacionar podem apresentar elevado índice de correlação (superior a $\pm 0,7$ ), sem todavia haver nenhum signifi cado entre as mesmas; igualmente, ocorrem relacionamentos de cer to modo importantes entre duas variäveis, mas o indice de corre lação entre as mesmas e insignificante (inferior a $\pm 0,3$ ).

No estudo em questão, a segunda hipötese foi verificada 
frequentemente, devido a presença de valores anômalos e excessi vamente elevados, tanto de vazão específica como de resíduo seco, - que propiciava coeficientes de variação superiores a $100 \%$. Nes sa situação, os parâmetros estatísticos eram "mascarados" e os valores dos indices de correlação se mostraram sempre muito bai xos (no mäximo atingiram a $\pm 0,3$ ).

Essa condição restritiva à pesquisa, foi atenuada por uma criteriosa anälise dos dados, através de estudo de frequência de ocorrência de valores por faixas da variävel independente. Des sa maneira, foi possivel detectar-se os relacionamentos por fun cões diretas, inversas ou especificas, entre as variäveis anali sadas.

\subsection{AGRADECIMENTOS}

o autor agradece sensibilizado, às entidades jurídicas e fisicas a seguir mencionadas:

- A Diretoria e aos geólogos das empresas CDM-Companhia de Desenvolvimento Mineral do Rio Grande do Norte e CDRM-Companhia de Desenvolvimento de Recursos Minerais da Paraiba, que gentilmen te facilitaram o uso dos dados dos poços de sua propriedade.

- Ao CNPq-Conselho Nacional de Desenvolvimento Científi co e Tecnológico, pela ajuda concedida em forma de auxílio de pes quisa, para elaboração do trabalho de campo

- Ao Instituto de Geociências da Universidade de São Pau 10 e em especial ao DGE pela agradävel permanencia e facilidades proporcionadas durante a fase de obtenção de crëditos

- Ao Prof.Dr. Aldo da Cunha Rebouças, pela orientação e constante incentivo ao desenvolvimento e apresentação do trabalho

- Aos colegas da UFPE, com destaque para Lucia Seve de S.Barbosa, Rilson R.da Silva, Alcides da N.Sial e Benjamin Bley de B. Neves, pelo constante incentivo

- Aos meus familiares (pais, esposa, filhos, irmão Wa1 ter e sobrinho Almir) que direta ou indiretamente contribuiram para a apresentação deste trabalho. 
P A R T E 1:

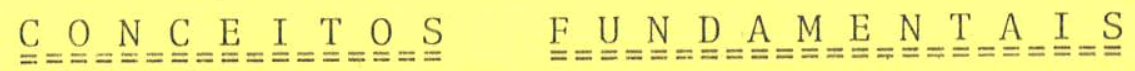


CAP ITULO NO 2

FATORES QUEE ATUAM NO AQUT FERO FISSURAL 
Segundo COSTA $(1965,80,85)$, os fatores que atuam na hidro geologia do meio rochoso fraturado, ou aquífero fissural, podem ser agrupados em dois grupos, a saber:

a) fatores exógenos (ou extrínsecos)

b) fatores endógenos (ou intrínsecos)

o primeiro grupo diz respeito aos condicionantes relacio nados aos agentes atuantes na superficie externa do globo terres tre, tais como clima, relevo, hidrografia, vegetação e outros.

o segundo, corresponde aos agentes que atuam no interior do globo, tais como: estruturas representadas pelas rochas em fun căo de esforços atuantes na crosta, constituição litológica, pre sença de soluções mineralizantes, etc.

Segue-se uma descrição de cada fator exógeno e endögeno, com um estudo mais detalhado desses últimos, por participarem com mais intensidade do processo hidrodinâmico do aquifero fissural.

\subsection{TATORES EXOGENOS}

\subsubsection{CLIMA}

A principal influência do clima ë na qualidade da ägua. Em regiōes de mais elevada aridez, como no Nordeste do Brasil, em que a evaporação ultrapassa a precipitação, os sais solüveis pre cipitam na superfície ou logo abaixo dela, sendo redissolvidos a travês das ảguas que se infiltram, aumentando gradativamente a salinização das äguas armazenadas nas fraturas das rochas. Atua 1 mente, esse fator $\vec{e}$ considerado como o mais importante no proce $\underline{s}$ so de salinização das äguas de regiões cristalinas semi-äridas. Esse fator vai influir, de modo indireto, também na hidrografia e vegetação, como serä visto adiante. 
Quanto a sua influência nos volumes armazenados., sua participaçäo ê apenas moderada, Com efeito, em regiões de maior precipitação pluviomêtrica, com regime semi-perenizado dos curs: sos fluviais, a tendência ê para haver uma maior recarga e portanto, aumento na quantidade de ägua exploräve1. E claro que so mente esse fator não irä determinar boas vazōes nos poços, pois $\vec{e}$ necessärio que haja estruturas acumuladoras onde a ägua seja ar mazenada.

2.2.2. RELEVO

Esse fator ê de capital importância na quantificação de volumes infiltrados e armazenados, ou seja, na quantidade de äm gua acumulada nas fraturas do "cristalino".

Atê então, nâo havia sido realizada, em âmbito nacional , qualquer análise da influência do relevo na quantificação dos volumes exploráveis. Trabalhos internacionais já levaram em con ta esse fator, como os de LEGRAND (1950) nas âreas de Carolina do Norte, Pittsylvania e Halifax (EUA), incluindo 772 poços e de SEVER (1964) em Dawson, Georgia (EUA) com 50. poços.

Nos referidos trabathos foram abordadas diferentes situa ções de relevo, como elevações, depressões, encostas de vales e planícies. Foi demonstrado que os poços perfurados nos talvegues dos vales apresentavam as melhores vazōes, secundados pelos localizados nas planícies, nas vertentes e por fim nos topos de eleva ções.

No que se refere a influência na qualidade da âgua, não existem dados estatísticos completos. Entretanto, a prätica tem demonstrado, que na regiâo semi-ärida, os poços localizados nos vales dos rios principais, tendem a possuir maior salinidade do que nos riachos tributários. Por outro lado, os poços perfurados nos flancos das elevações, nas porçöes tópogrâficas menos elevadas, apresentam em geral, salinidade mais reduzida, enquanto no topo das elevaçöes, aumenta a salinidade. 


\section{$2,2.3$. HIDROGRAFIA}

No inficio da década de 6.0, quando surgiram no Brasil as primeiras pesquisas hidrogeolögicas, nasceu o conceito que ain da hoje ê utilizado na locação dos poços, que foi o do"riachofenda". Esse termo representa justamente a associação da hidro grafia com a geologia, no sentido de proporcionar a melhor condição de infiltraçäo e armazenamento de água, em rochas duras fraturadas.

O "riacho-fenda" corresponde à situaçäo em que ocorre a coincidência da drenagem superficial com zonas fraturadas do em basamento rochoso. Nessa situação, facilmente reconhecida na fó tografia aérea e mesmo no local, devido a retilineidade adquiri da por trechos do rio ou riacho, segundo direçöes preferenciais, existe a condição de infiltração de ägua nas aberturas da rocha fraturada, com possibilidades favoráveis de armazenamento na sub superficie.

Nos casos dos rios perenes, a condição de recarga das fraturas e do aquifero fissural, se acha assegurada para permitir uma exploração sistemâtica por poços ali perfurados.

Quanto a influência da hidrografia na qualidade, $\vec{e}$ bastante relativa, pois dependerä da qualidade da ägua superficial. Quando a água superficial ê de boa qualidade, a sua in fluêncìa é benéfica ao aquífero, pois a sua infiltração promoverả a renovação da ägua subterrânea. Nessas condições, a perfuração de poços nos vales fluviais serâ favorẩel, poìs haverä melhor quantidade e qualidade de ägua. Quando todavia, a ägua superficial for salinizada, deve-se evitar os vales, notadamente dos rios mais extensos, mesmo que se caracterize a situação do "riacho-fenda".

\subsubsection{VEGETAÇĀO}

A atuação da vegetação ể baixa no que se refere a qualidade da ägua, pois quase näo participa esse fator no processo de salinização, a näo ser de forma indireta. E evidente que em regi- 
ões com abundante vegetação (mata, floresta, etc) a evapotranspi ração favorece uma precipitação mais intensa que proporciona a lixiviação dos sais solûveis contribuindo para uma melhor qualidade da âgua armazenada na sub-superfície.

Pela mesma razão, porêm de forma mais intensa, essa participação indireta proporcionarâ maior recarga dos aquíferos, ou seja, influi na quantidade dos recursos armazenados.

\subsubsection{INFILTRAÇÃO OU ASCENÇÃO DE SOLUÇOES}

Os dois casos, exôgeno e endốgeno, podem ser tratados con juntamente, pois acarretam o mesmo efeito, prejudicial ao armazenamento da água nas fraturas.

Com efeito, as soluçōes ricas em sílica, carbonatos,óxidos, etc, podem penetrar nas fraturas a partir da superfîcie ou originadas da profundidade (soluçöes juvenis do magma).

Ao concentrarem as soluçōes, e posteriormente com a evaporação da ägua, ocorre a recristalização dos sais, podendo inclusive provocar a impermeabilização total da fratura, que se diz regelada.

\section{$2.2,6$. COBERTURAS SEDIMENTARES}

Como coberturas são incluídos os capeamentos de uma sedimentação de material estranho ã rocha subjacente ou encoberta (cobertura alóctone) como os depósitos de aluviões e coluviões, bem como os materiais procedentes de processos de intemperismo da rocha subjacente (cobertura autóctone).

As coberturas autôctones, comumente denominadas de rego lito ou eluvião ou ainda manto de intemperismo, podem possuir espessuras reduzidas (alguns centímetros) quando originadas de processo físico por desintegração, ou de vầíos metros quando originadas por processos químicos (decomposiçäo). 
Nos clima:semi-äridos, como na regiäo nordeste do Brasil, o manto de intemperismo é muito reduzido, enquanto nas áreas mais umidas, com abundante pluviosidade, o manto ë em geral espesso.

A importância desse fator pode ser vislumbrada pelas diferentes vazões apresentadas pelos poços localizados em äreas com coberturas de regolito espesso, como no sul do Brasil, e as äreas praticamente sem coberturas do nordeste semi-ärido;nas pri meiras as vazões mêdias são em torno de 5 vezes (podendo chegar atë 10 vezes) as vazões mëdias das segundas.

A escolha de âreas com coberturas, em detrimento de outras sem cobertura deve ser associada a outras caracteristicas tais como:

a) constituição granulomêtrica da cobertura, devendo-se evitar as coberturas siltica-argilosas;

b) relevo, devendo-se evitar as coberturas situadas em formas topogräficas colinosas ou alongadas (espigões, divisores de bacias hidrogräficas, etc) ou ainda em bordas de elevações.

Quanto a influência do manto de intemperismo na qualida de da água, é apenas moderada, e de certo modo indireta, pois, se a existência do manto decorre de maior umidade, que por sua vez está associada a maior precipitaçäo, consequentemente as àguas serão melhores, conforme já abordado. 


\subsection{FATORES ENDOGENOS}

2.3.1. ESTRUTURAS GEOLOGICAS E MECÂNICA DAS ROCHAS

Um meio rochoso, como qualquer meio sólido descontínuo, estä sujeito a diferentes tipos de deformações, em função das suas características elásticas e mecânicas e do estado de ten sões a que estâ submetido.

$\mathrm{Na}$ evolução geolögica por que passa um determinado maci ço rochoso, esses fatores são extremamente condicionados pela variação de profundidade. Assim é que, grandes profundidades, predominam os elevados estados de tensões compressivas e as a1 tas temperaturas, condicionando uma plastificação do meio, com deformações por dobramentos e recristalizações de minerais, sem contudo desenvolver a deformação ruptura1.. Jä em pequenas profun didades, é menor o efeito da temperatura sobre as característi cas mecânicas da rocha e o estado de tensões é dos mais varia dos, permitindo a deformação ruptural dos maciços rochosos em diferentes estilos e direções.

A deformação que envolve a plastificação dos maciços ro chosos sem chegar à ruptura, somente piora as condições de perme abilidade desses maciços, jā que a recristalização reduz a poro sidade intersticial. Por esse motivo, não será desenvolvido no presente trabalho, esse tipo de deformação.

\subsubsection{1-Mecanismo da Deformação Ruptural no Maciço Rochoso}

A anā1ise da deformação ruptural, que possa ser adaptada às condições geolögicas, deve considerar, em princípio, que o meio a se deformar ê quase homogêneo, continuo e isotrópico.

Nessas condições, serão analisados os diferentes tipos de rupturas ocorrentes, em função dos värios estados de tensões que podem solicitar um corpo.

Em princípio, podem ocorrer tensões normais (o) às fa ces do corpo, puramente compressivas (Fig.2.HA) ou puramente tra cionais (Fig.2.7B). Em ambos os casos, desenvolvem-se tensões 


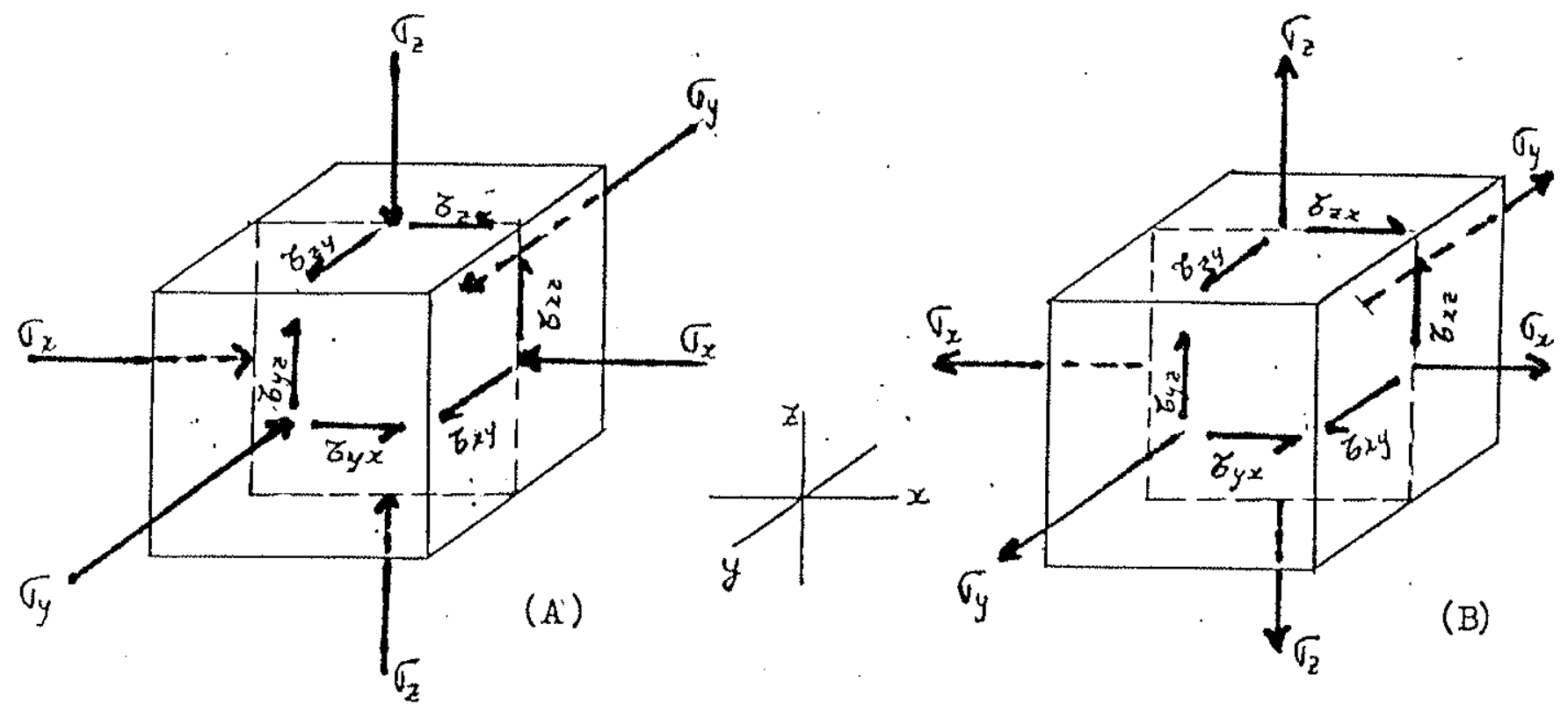

BIG.2.1- Esquema de tensões aplicadas a un corpo. Em A as ten sões normais $(\sigma)$ são compressivas e em B são tracionais. De senvolvem-se ainda, em ambos os casos as tensões tangenciais ( 6 ) ou de cisalhamento.

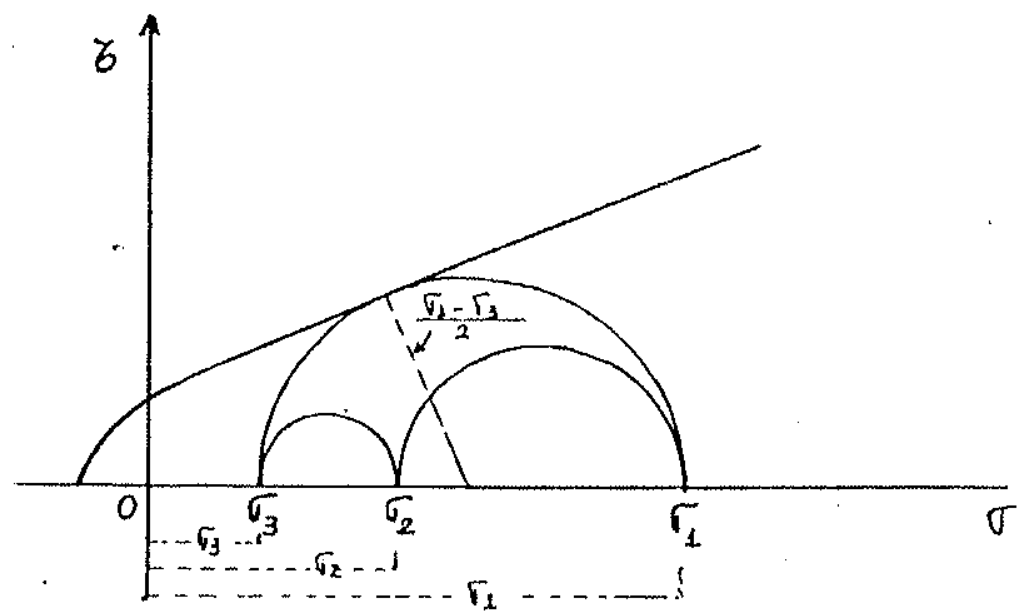

FIG.2.2- Gráfico de Mohr, mostrando que a envoltória de rutura apenas tangencia o círculo de raio $\left(\frac{\sigma_{1}-\sigma_{0}}{2}\right)$ 
tangenciais ou de cisalhamento $(\zeta)$, conforme indicado na Fig. .

Pode ainda estar o corpo submetido à tensöes normais compressivas em determinada direção e tracionais em outra,o que não altera a distribuição demonstrada nas Fig.2.1(A e B) para as tensões tangenciais.

$\mathrm{Na}$ anâlise de runtura, apenas interessa conhecer a dife rença entre as tensões normais mäxima $\left(\sigma_{1}\right)$ e minima $\left(\sigma_{3}\right)$, pois a tensão normal intermediâria $\left(\sigma_{2}\right)$ jamais interferirá na ruptura , conforme mostra o gräfico de Mohr da Fig.2.2, segundo ZrENKIEWICZ (1968).

Nessas circunstâncias, toda a anảlise de ruptura serā de senvolvida, ao longo do plano que contëm as tensöes normais $\sigma_{2} e$ $\sigma_{3}$ (esquema bidimensional) e que corresponde ao plano mostrado em tracejado nas figuras $21-A$ e 21-B, considerando que essas ten söes estejam ocorrendo nas direçöes $x$ e $\underline{z}$ naquelas figuras.

No estado de tensões uniaxial $\left(\sigma_{2}=\sigma_{3}=0\right)$, de compressão, desenvolvem-se no corpo comprimido, tensões de tração $\left(\sigma_{t}\right)$ no sen tido transversal à tensão de compressão, conforme mostra a Figu ra 23. . Se essas tensões tracionais geradas ultrapassarem a re sistência à tração do corpo $\left(S_{t}\right)$, ocorrerá ruptura por tração, ao longo do plano perpendicular às tensões de tração geradas, de $\underline{a}$ cordo com o esquema de ruptura representado pelo gräfico de Mohr da Fig.2.3-A.

A Fig 23-B mostra o mesmo tipo de ruptura, para o estado de tensões mista, em que $\sigma_{2} \bar{e}$ de compressão e $\sigma_{3}$ é de tração, sen do que, nesse caso, é iminente a rutura de tração, pois a tensão $\sigma_{t}$, acrescida de $\sigma_{3}$ é sempre superior à resistência à tração do corpo, $S_{t}$ (JAEGER \& COOK, 1968).

Voltando ao estado uniaxial compressivo, se a tensão $\sigma_{t}$ for inferior à resistência $S_{t}$, não ocorrerä ruptura por tração,po dendo então ocorrer ruptura por cisalhamento ou simplesmente não haver qualquer tipo de mutura.

Para que haja a ruptura por cisalhamento, è necessärio que a tensão de cisalhamento $(\zeta)$, gerada pela compressão, seja superior à resistência ao cisathamento do corpo $\left(S_{S}\right)$ e nesse ca so, a rupcura ocorrerá segundo um dos dois (ou ambos) planos in clinados representados na Fig.2.4, e de acordo com o esquema mos trado pelo gräfico de Mohr dessa mesma figura. 

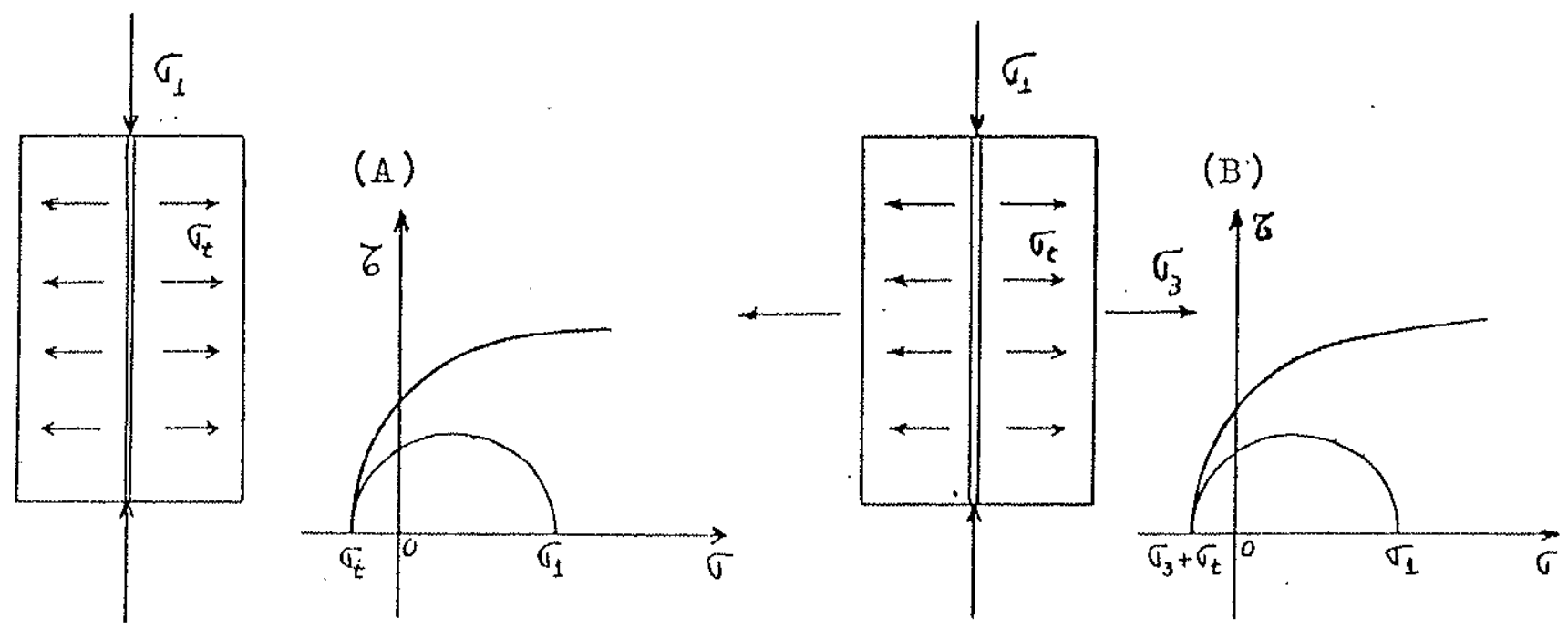

FIG.2.3- Tensões de traçäo $\left(\sigma_{t}\right)$ desenvolvidas num corpo submeti do à compressão. Em A, estado de tensões uniaxial e em B, esta do de tensões misto, com $\sigma_{1}$ de compressão e $\sigma_{3}$ de tração.
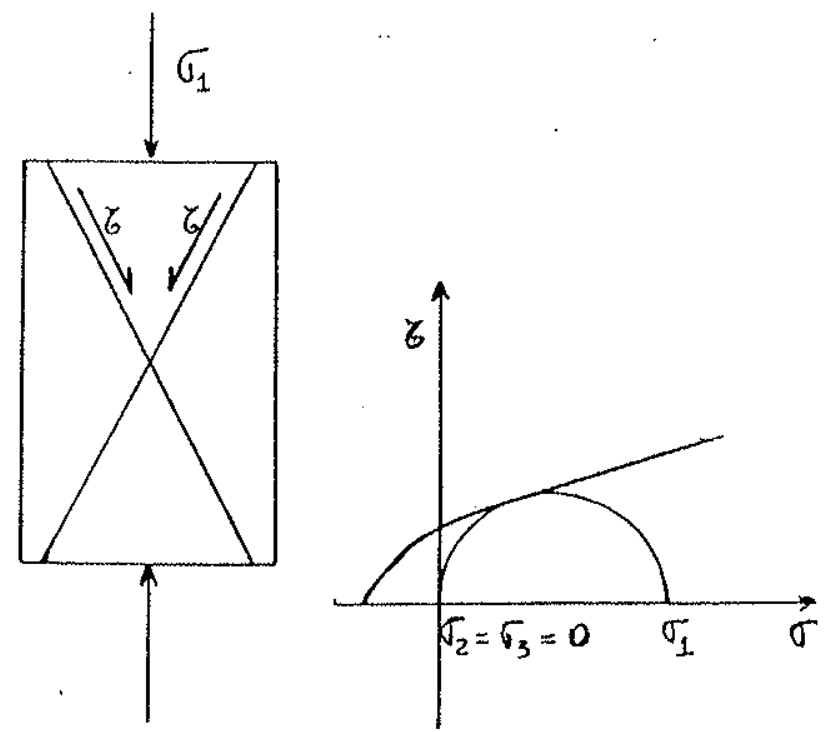

FIG.2.4- Planos em que se desenvolvem as ruturas por cisalhamento quando a tensão de cisalhamento ultrapassa a resistemcia de cisalhamento.

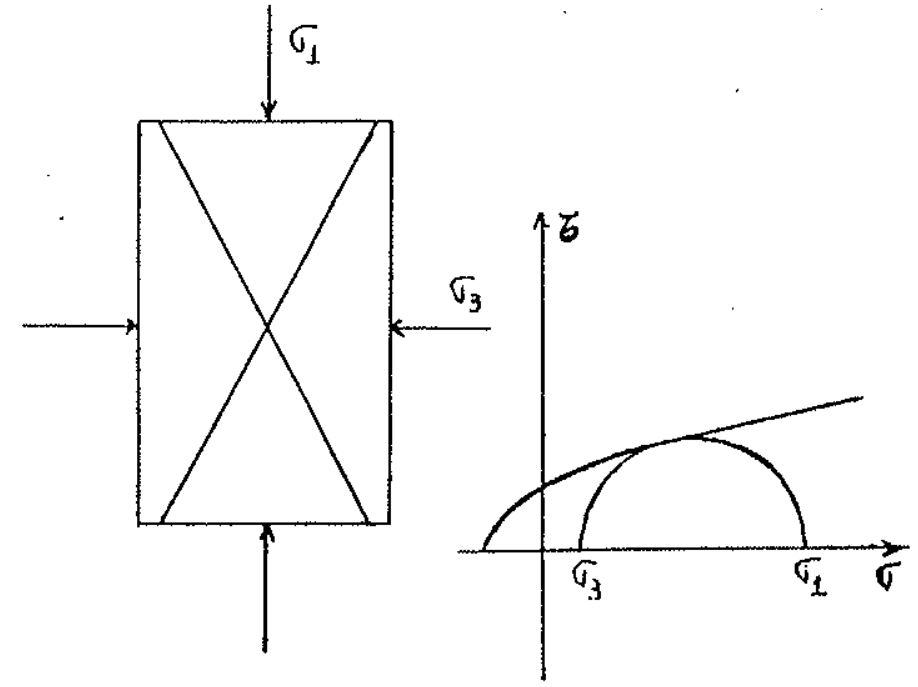

FIG'25- Planos de ruptura por cisalhamento, desenvolvidos no estado de tensões triaxial compressivo. Variação apenas no Gráfico de Mohr. 
No estado de tensões triaxial compressivo, as tensões $\sigma_{2}$ e $\sigma_{3}$ vão reforçar a resistência à tração do corpo e por isso, è di fícil ocorrer a rultura por tração, a não ser em casos onde a ten são mínima é muito pequena e a resistência à tração muito baixa. En geral, ocorrexả para esse estado de tensões, a ruptura por cisa thamento, conforme os esquemas da Fig. 2.5.

A inclinação do plano de ruptura por cisalhamento, com re lação ao maior esforço, depende do ângulo de atrito do corpo ( $\phi$ ) Teoria de Coulomb e Navier, citada por OBERT e DUVAJ(1967). Esque matizando a distribuição de tensões geradas por $\sigma_{1}$ em relação a um dos planos de cisalhamento mostrados na Fig 2.5, pode-se observar atravês do grä́fico de Mohr (Fig.2.6), que o ângulo a em questão, è expresso pela seguinte equação:

$$
\alpha=45^{\circ}-\frac{\phi}{2}
$$

sendo $\propto$ o ângulo de inclinação do plano de ruptura por cisalhamento.

As deformações rupurais que ocorrem no campo geológico têm o mesmo mecanismo explicado anteriormente. Importa todavia analisar, a influência exexcida pelos diferentes estados de ten sões atuantes, onde assumem particular importância, as de origem tectônica, alêm das características elästicas e de resistência das rochas. Outros fatores que merecem ser analisados, são as descontinuidades intrínsecas do maciço rochoso, alëm dos proces sos dinâmicos externos e internos que ocorrem na crosta terres tre.

Essa anälise é de grande importância para a compreensão dos problemas relacionados ao armazenamento da ägua, servindo, so bretudo em rochas orientadas, para distinção entre as fraturas tracionais e as de cisalhamento, como será abordado adiante.

As tensões tectônicas atuam no sentido tangencial à sụ perficie da crosta terrestre, em suas camadas ou geosferas mais profundas. Assim, quando um maciço rochoso estä sujeito a essa condição, o seu estado de tensões pode ser definido por um dos dois elipsōides de tensões mostrado na Fig. 2.7.

os fatores que irão condicionar um desses dois tipos de 
estado de tensões são: peso do recobrimento rochoso, em função da profundidade em que ocorre o fenômeno e estado de confinamen to lateral a que estä sujeito o maciço ao se deformar.

Predominando o estado de tensões mostrado na Fig.2.7-A as deformações rupturais ocorrem segundo os planos indicados na Fig.2.8. Nesses casos, a muptura ocorre por cisalhamento e seus pla nos correspondem ao tipo kO1 de Sander(1948) descritos por LARSSON $(1963,1967,1968,1977)$, porẻm limitados àqueles de fraca inclina ção, pois o ângulo de mergulho desses planos rupturais (interseção com o plano horizonta1), corresponde ao ângulo $\alpha$ definido na Fig. 26. Pela equação (1) êsse ângulo ê função do ângulo de atrito $\phi$ do maciço rochoso. Considerando que $\phi$ varia entre $30^{\circ}$ e $60^{\circ}$ para os diferentes tipos de rocha (RZHEWSKY e NOVIK,1971), conclui-se que o ângulo $\alpha$ deve variar entre $15^{\circ}$ e $30^{\circ}$.

Quando o estado de tensões existente, corresponder ao mostrado na Fig.2.7-B, as deformações rupturais serāo do tipo indi cado na Fig2.9. Nesse caso, os planos de ruptura são sempre vert cais, podendo ocorrer dois tipos de ruptura: por cisalhamento e por tração. Se a tensão $\sigma_{3}$, acrescida da resistência à tração da rocha, for superior à tensão $\sigma_{t}$ gerada por $\sigma_{1}$ (caso mais fre quente) predominará a ruptura por cisalhamento, com planos verti cais formando um ângulo máximo de $60^{\circ}$ entre si $(2 \alpha)$ com $\sigma_{1}$ em sua bissetriz. Esses planos correspondem aos hk0 de Sander, con forme mostrado na Fig. 2.9. Desde que $\sigma_{t}$ suplante a resistência à tração acrescida de $\sigma_{3}$, ocorrerá a ruptura por tração, segundo pla nos verticais paralelos a $\sigma_{1}$, e que correspondem ao plano ac de Sander (Fig.2,9).

E importante observar que, por sua pröpria gênese, os planos de runtura por tração tendem a ser abertos, enquanto os de cisalhamento são fechados.

Finalmente deve ser analisada a situação geológica em que a deformação ruptural estä associada à deformação por dobra mento. Considerando uma camada de competência mëdia a alta, sen do comprimida horizontalmente, em condições que propiciem um do bramento acompanhado de rupturas, deve ser levado em conta que,o dobramento gera tensões secundārias importantes, que diferem ao longo da espessura da camada dobrada. Como e mostrado na Fig.2.10 desenvolvem-se tensões de tração $\left(\sigma_{t}^{\prime}\right)$ na parte externa da dobra 

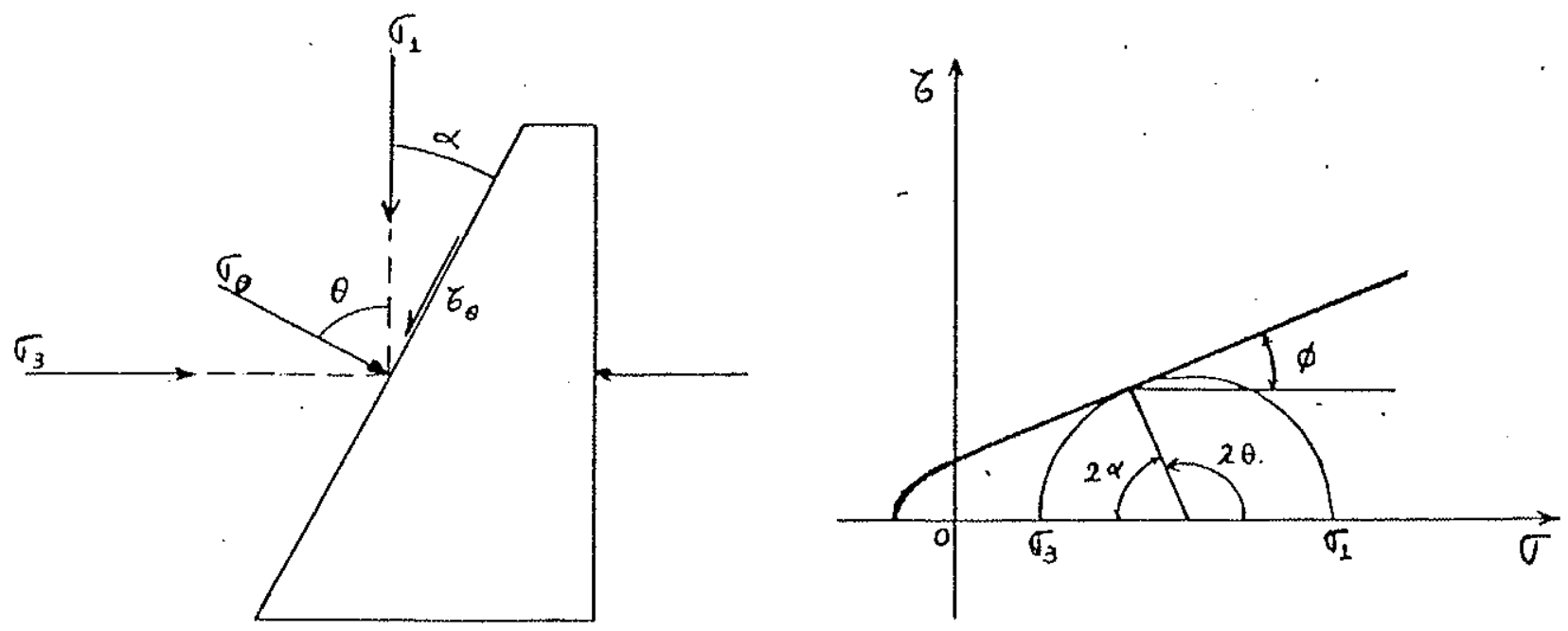

FIG.2.6- Relação entre o ângulo de inclinação do plano de rutura por cisalhamento $(\alpha)$ e o ângulo de atrito do corpo ( $\phi$ ). $\sigma_{\theta}$ é a tensão normal que atua sobre o plano de rutura.
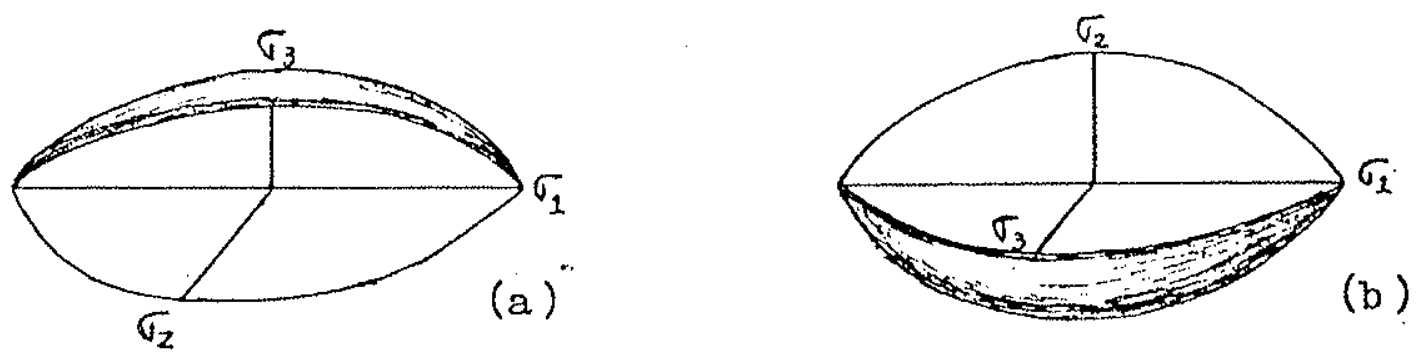

FIG.27- Elipsóides de tensões tectônicas. Em a , a menor tensão $\left(\sigma_{3}\right)$ está na vertical e em b está na horizontal. A maior tensão $\left(\sigma_{1}\right)$ é sempre na horizontal. Em ambos os casos irá ocorrer fraturamento por cisalhamento, segundo direções diferentes, conforme o caso. 


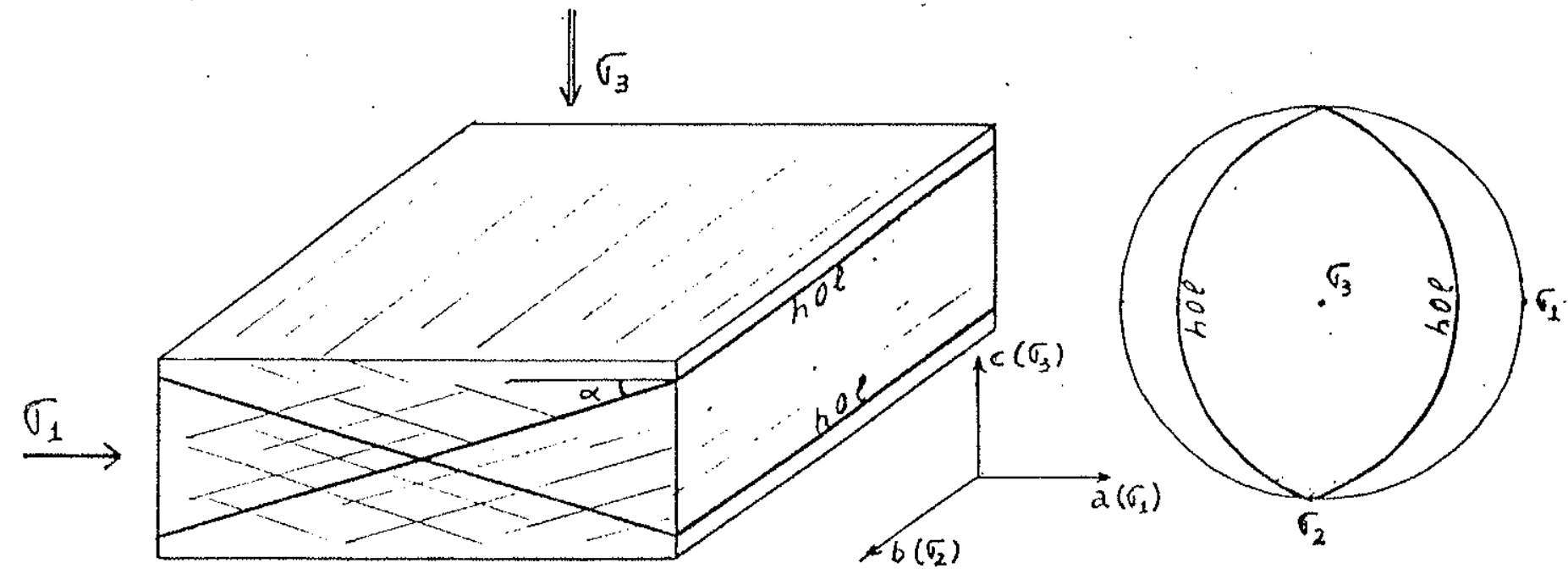

FIG.2.8- Planos hol (conf.SANDER) em que ocorrem as fraturas de cisalhamento em função de tensões atuantes conforme a Fig.2. 7-a. Ao lado, representação dos planos em estereograma.

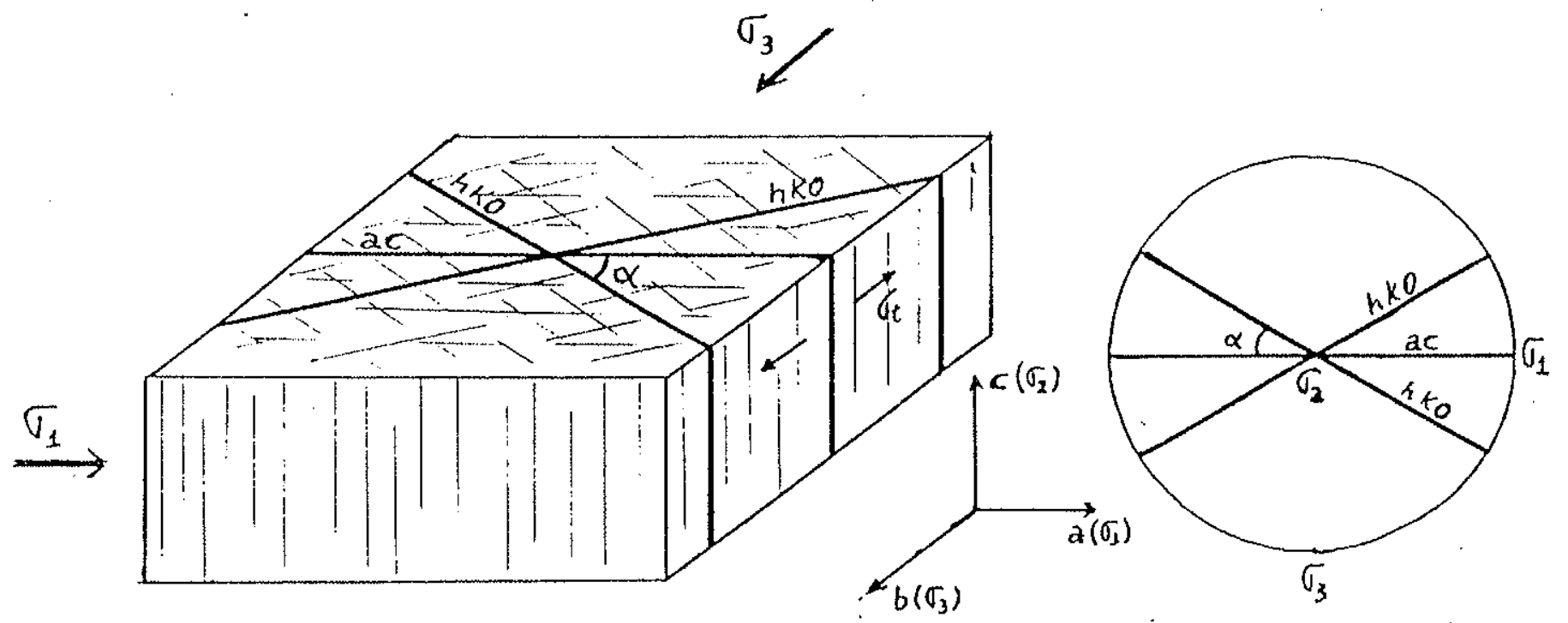

FIG.2.9- Quando o estado de tensões atuante corresponde ao da FIG 2.7-b, podem se desenvolver fraturas de cisalhamento(hko de SANDER) ou de tração (ac). Ao lado, representação em estereograma. 
e de compressão $\left(\sigma_{c}\right)$ na parte interna. As primeiras, criam ruptu ras por tração, cujos planos são paralelos ao eixo do dobramento, cnquanto a compressão geralmente deforma a parte interna de do bras por enrugamento ou por esmagamento.

Esse novo tipo de ruptura por tração ocorre perpendicu larmente à superfície da camada dobrada. Assim, nas dobras simé tricas, como a mostrada na Fig.210, a ruptura mais central corres ponde ao plano axial. e contem a crista da dobra, sendo portanto um plano vertical, correspondente ao plano bc de Sander. Os de mais planos desse tipo de muptura, apresentam 1igeira inclinação em direção ao centro de curvatura da dobra, sendo tal inclinação indicada no estereograma ao lado da Fig.2.10, onde tais planos a parecem como meridianos pröximos ao centro.

Deve-se, todavia, ter em conta que nas dobras sinformes, as fraturas que ocorrerão paralelamente ao eixo da dobra, não se rão de origem tracionais, nem muito menos serão abertas.

\subsubsection{2- Mecânica das rochas}

Embora a ruptura dos maciços rochosos, seja fundamental mente dependente do estado de tensões atuante sobre as mesmas, há de se considerar a importância das características físicas da rocha, no comportamento ruptural desses maciços.

A primeira influência jả foi citada e refere-se ao ân gulo de atrito $\phi$, responsävel pelas relações geométricas entre os planos de cisalhamento e as tensões atuantes. Esse parâmetro $\bar{e}$ uma parcela da resistência ao cisalhamento $-\mathrm{S}_{\mathrm{S}}$ - que depende da seguinte equação:

$$
\zeta=c+\sigma \operatorname{tg} \phi
$$

o segundo membro dessa equação, corresponde a $S_{s}$, que deverā ser igual ou maior que $\zeta$, para que não haja rutura.

Dessa equação do equilíbrio de cisalhamento, os elemen $\operatorname{tos} \zeta$ e $\sigma$, dependem do estado de tensões atuantes, conforme foi mostrado na Fig.2:6. Todavia, os parâmetros c (coesão) e $\varnothing$ (ângulo de atrito) são intrinsecos da rocha e que definem a sua resistên cia à mutura por cisalhamento. 
Assim, quanto maior for o valor desses parâmetros, mais intensivo necessitará ser o estado de tensões para provocar a rup tura por cisalhamento e menor serā o ângulo $\alpha$, entre $\sigma_{1}$ e o pla no da runtura.

Outra característica física da rocha, que influi na rup tura, $\vec{e}$ o seu mödulo de elasticidade (E), em função da seguinte expressão:

$$
\sigma=\mathrm{E} \cdot \varepsilon
$$

onde:

$$
\begin{aligned}
\sigma & =\text { tensão aplicada } \\
\mathrm{E} & =\text { Môdulo de Elasticidade } \\
\varepsilon & =\text { Deformação sofrida }
\end{aligned}
$$

Pela equação(3), constata-se (PRICE,1966) que, quanto maior for o mödulo E de uma rocha, mais intensas serão as tensoẽs geradas, em função de uma carga aplicada. Disso resulta que, as tensões de tração $\left(\sigma_{t}\right)$ geradas pelo esforço compressivo (Figs.2.3, 9 e 10$)$, serão bem maiores nas rochas de maior módulo de elasti cidade, ou seja, nas rochas mais resistentes, propiciando uma miorabertura entre os planos de ruptura por tração.

o módulo de elasticidade E influi ainda na deformação ruptural em função da energia de deformação. Segundo PRICE(1959), a intensidade de fraturamento de um maciço rochoso, depende da energia de deformação $\underline{w}$, acumulada nesse maciço e que é definida pela equação:

$$
\mathrm{W}=\frac{\sigma^{2}}{2 \mathrm{E}}
$$

Nessas condições, è maior a frequência de planos de ru tura, nas rochas de mais baixo mödulo E.

Analisando-se todas as influências das características físicas das rochas em sua deformação runtural e, levando-se em consideração as propriedades litológicas, consequentes da compo sição mineralógica e tipo de textura, pode-se chegar às seguin tes constataçöes:

a) o comportamento estrutural de uma rocha ao ser ten sionada, depende das proporções existentes entre os minerais de resistências diferentes; 
b) os minerais granulares e isentos de planos de cliva gem, como o quartzo, são os mais resistentes ao cisalhamento e possucm maior módulo E. Os mincrais placosos são os menos resis tentes e de mais baixo mödulo E;

c) quanto mais grossa a textura da rocha, menor serä a sua resistência, pois será maior a influência dos planos de cli vagem dos cristais mais desenvolvidos (como os feldspatos); as sim, as rochas tipo pegmatito, granito pörfiro e similares, são mais quebradiças que as rochas do tipo diabäsio, traquito e ou tras granulares finas;

d) as rochas não orientadas, com predomínio de minerais rosistentes, apresentam geralmente uma baixa frequência de ruptu ras, todavia são mais abertos os planos de fraturas originados por tração;

e) nas rochas metamórficas orientadas, quanto mais bai xo o grau de metamorfismo, menor é a resistência ao cisalhamento e mais elevada a energia de deformaço acumulada, aumentando a intensidade de ruptura por cisalhamento. Todavia, as rupturas por tração apresentam planos quase tão fechados quanto as de ci salhamento. E o caso das ardóséas e filitos, que embora possuam uma grande quantidade de fraturas, essas são em geral, quase fe chadas;

f) nas rochas orientadas, de elevado grau de metamorfis mo, a resistência ao cisalhamento é maior e a energia de deforma ção acumulada $\vec{e}$ baixa, no que resulta um menor nümero de fratu ras, porém com maior abertura (nas fraturas tracionais). E o ca so dos gnaisses e secundariamente, dos micaxistos, onde a inten sidade de fraturas é baixa e as suas aberturas são relativamente maiores do que as rochas de baixo grau metamórfico.

\section{$2.3 .1 .3-$ Processos dinâmicos na crosta terrestre}

A evolução tectônica por que tem passado a crosta ter restre, envolveu uma contínua transformação de materiais, que assumiram aspectos liticos e estruturais variados, em função dos diferentes processos a que foram submetidos, na complexa dinâmi ca que ocorreu durante a sua formação. 
Assim $\vec{e}$ que, muitos sedimentos foram afundados, atraves das grandes bacias geossinclinais, passando seus materiais, das condições reinantes na superfície, para as elevadas pressões e temperaturas reinantes nos processos orogenéticos desenvolvidos em profundidade. Por outro lado, os movimentos epirogenëticos causaram o levantamento de extensos blocos e o afundamento de outros, numa constante troca de ambientes para esses materiais.

De todas essas relações entre processos dinâmicos de origem tectônica e isostätica, ressalta-se uma situação que muito tem influido na caracterização da deformação ruptural dos maciços rochosos. Referese ao processo de epirogênese positiva em uma região da crosta anteriormente afetada por processos oro genëticos.

Durante a orogênese, elevadas tensões tectônicas fica ram confinadas no maciço formado, no plano tangencial à crosta, porëm em profundidade. Evidentemente, as maiores tensões se acu mularam perpendicularmente à xistosidade imposta à rocha forma da (COSTA, 1972). Quando esse maciço for soerguido até a superfí cie da crosta por epirogềnese, passarâ a ocupar um maior espaço latera1, pois a circunferência da terra vai aumentando o seu raio de curvatura de dentro para fora, conforme mostra a Fig.2.11. Quando o bloco $A B C D$ subiu da posição 1 para a 2 , houve um acrés cimo lateral de espaço correspondente a $\Delta \mathrm{L}$ e, nessas condiçōes, as tensões de compressão que estavam confinadas nesse bloco, na posição 1 , foram liberadas, quando o bloco atingiu a posição 2 , passando a funcionarem na forma de tração nessa posição.

Como resultado, surgem fraturas de traçäo, perpendicu lares a essa nova tensão e portanto, paralelas aos planos de xis tosidade, porém possuem seus planos geralmente abertos, por re sultarem de tensões tracionais. (ver Fig.2.12).

Esse $\vec{e}$ um dos aspectos que se relacionam com a superpo sição de esforcos em distintas etapas ou ciclos orogenéticos, fa zendo com que extensos ou reduzidos alinhamentos de falhas de cí salhamento (transcorrentes) sejam reativados em movimentos traci onais, propiciando condições hidrogeolögicas favoräveis, no con texto do aquífero fissural. Na região Nordeste do Brasil, são en contrados vários exemplos dessa situação de mültiplas fases de de formação. 


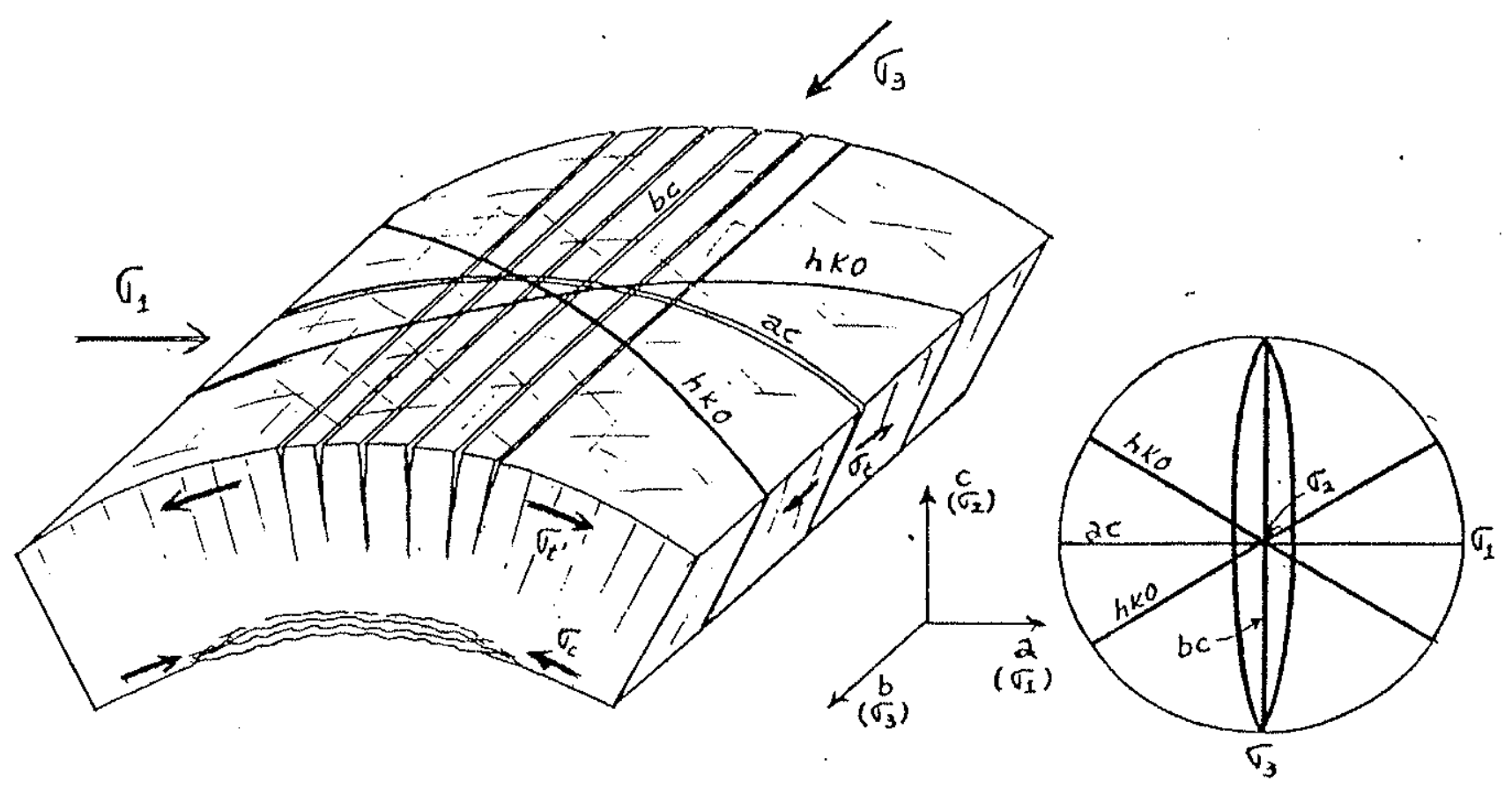

FIG. 2.10- Fraturamento em dobras de grande raio de curvatura. A fratura mais central coincide com o plano axial e contem a crista da dobra (fratura be de SANDER.). As demais desse tipo (paralelas a bc) apresentam ligeiro mergulho para o centro da dobra. Os demais tipos (ac e hko) já foram vistos atrás.

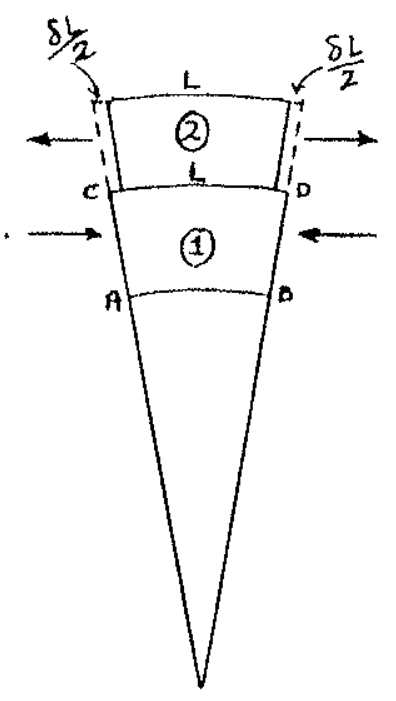

FIG.2.11- 0 bIoco ABCD subiu por epirogênese da posição (1) para (2), havendo um acréscimo de espaço lateral $\Delta I$ longitudinais.

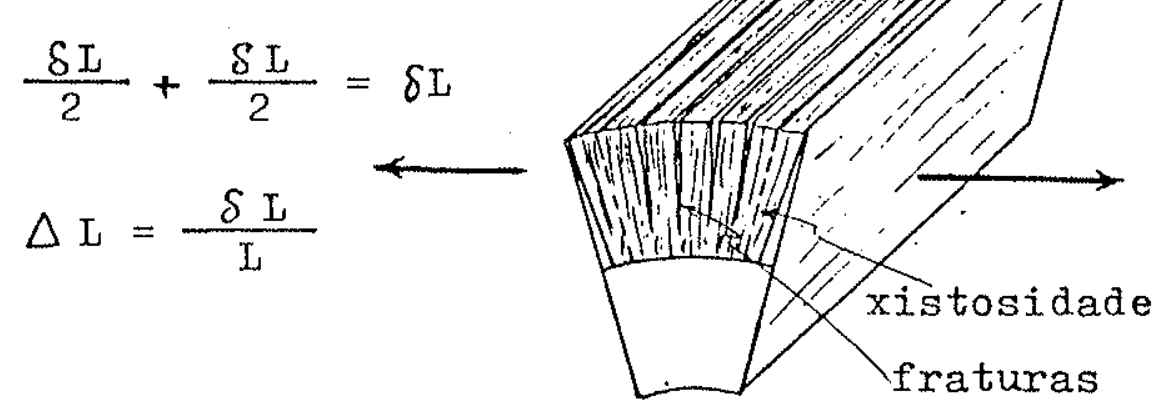

FIG.2.12- Como resultado, surgiram fraturas de tração paralelas à xistosidade, chamadas de 
Por outro lado, Cos'A (1972) mostrou que, frequentemente, blocos do maciço rochoso ao sofrerem ruptura por tração na parte mais superficial da crosta, são deslocados pelo clcito do seu pró prio peso e, nesses casos, tudo se passa como se a maior tensão compressiva estivesse na vertical, produzindo falhas de gravida de (teoria aventada por CosTA op cit, para explicar a origem dos falhamentos da Serra do Mar). O esquema dessa deformação ruptural corresponde ao apresentado na Fig.2.13.

Nesses casos, embora a ruptura tenha sido originada por tração, os planos se encontram pouco abertos a fechados, pois o comportamento de deslocamento dos blocos fraturados é análogo ao de ruptura por cisalhamento, podendo inclusive, dar origem a for mação de "si.icken-sides". Dessa forma, a situação hidrogeológica resultante $\vec{e}$ desfavorảve1, representando uma inversão da condição normalmente propiciada pelos movimentos tracionais.

\section{3 .1 .4 - Descontinuidades intrinsecas do macico rochoso}

Quando um maciço rochoso orientado (estratificado p.e.) $\vec{e}$ tensionado, nem sempre as rupturas obedecem aos modelos descri tos anteriormente, porem tal fato, em nada invalida os princípios demonstrados, para explicar o mecanismo dos diferentes tipos de ruptura.

Acontece que, os parâmetros físicos que comandam a ampli tude da ruptura e o posicionamento dos planos de quebramento, den tre os quais se destaca o ângulo de atrito, não são uniformes ao longo de toda a rocha, sendo mais influentes para a ruptura, aque les correspondentes aos minerais mais fracos ou aos planos de des continuidade já existentes.

Assim, ao menos que tenha havido uma cimentação secunda ria, ao longo de um plano pré-existente de descontinuidade, como de xistosidade, estratificação, ou qualquer outra orientação de minerais (principalmente placosos), esses planos possuirão parâ metros físicos de resistência e elasticidade, bastante inferio res aos do restante da rocha. Nessas condiçōes, serä preponderan te a influência desses planos de fraqueza na ruptura da rocha, e, 
consequentemente, será de grande relevância a relação existente entre a orientação do plano de descontinuidade e os esforços a plicados.

A experiência tem demonstrado (RAGAN,1968), que o ângu 10 máximo de 30 o constatado pela equação (1), em função do ângu 10 ф das rochas, entre o plano de ruptura por cisalhamento e a tensão compressiva atuante, pode chegar a 60 , em função da in fluência das descontinuidades do maciço.

Idêntico efeito pode acarretar as excessivas elevações de pressão e temperatura, nos esforços originados a grandes pro fundidades da crosta.

\section{$2.3 .1 .5-$ processos físicos exögenos}

Um outro tipo de ruptura de meios rochosos, consequente de alivio de tensões, ocorre relacionado com os processos exter nos de medelagem da crosta terrestre, atravẻs da erosão (proces so atectônico).

Quando o maciço rochoso se encontra na proximidade da superfície terrestre, a tensão $\sigma \vec{e}$ muito baixa e corresponde ao peso do recobrimento existente sobre o maciço considerado.

Se esse recobrimento for retirado, pelo efeito da ero são, a tensão $\sigma$ que anteriormente era compressiva, torna-se a $\underline{1} \underline{i}$ viada pela falta do material retirado, transformando-se numa ten são de tração, de forma anâloga à descrita com a Fig.2.11.

Em consequência, aparecem planos de ruptura perpendicu lares à tensão de tração surgida e como essa é perpendicular à superfície de erosão, aquelas rupturas ocorrem sempre paralela mente à superficie topogräfica.

Essas fraturas são denominadas de "sheet joints" ou jun tas de descompressão. Sua abertura depende da espessura de mate rial rochoso que ainda se mantem acima do plano de ruptura, mas em geral, são bem abertas, pois uma vez quebradas pela tensão tra cional supra descrita, não voltam mais a se unirem cos blocos a fastados ou abertos) devido às irregularidades do plano de ruptú 


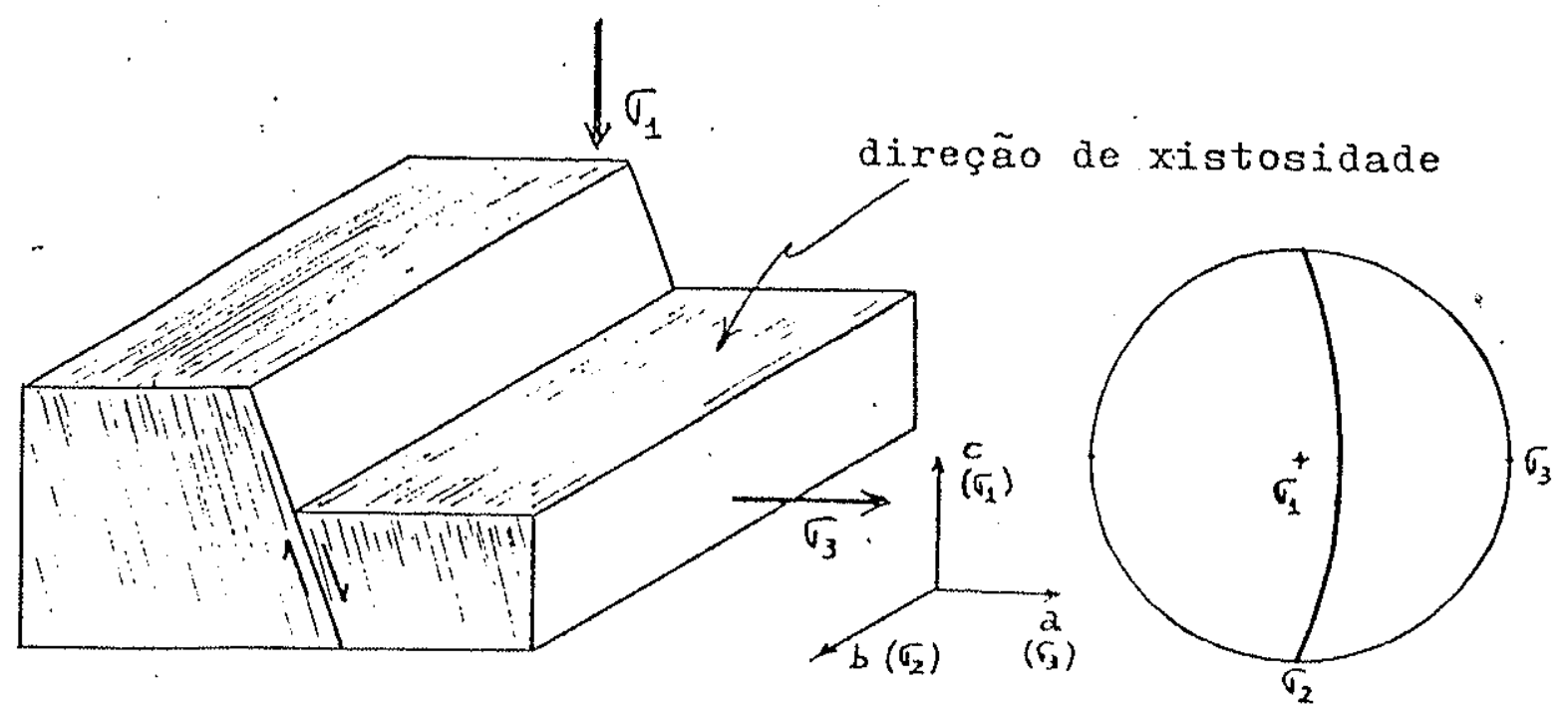

FIG. 2.13 - Esquema ilustrativo de um falhamento de gravidade produrido por um esforço tracional próximo ̀̀ superfície. Tudo se passa como se a maior tensão compressiva estivesse na ver tical. (seg.COSTA-1972).

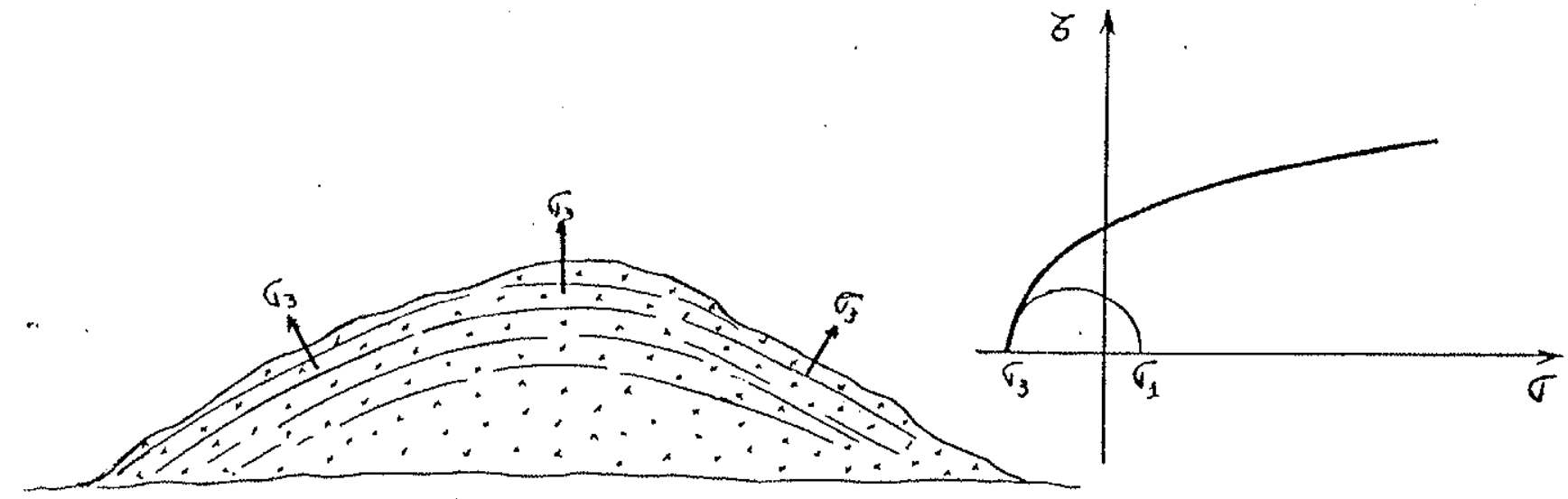

FIG.2.14- Esquema da formação das juntas de descompressão ou "sheet joints". Pela erosão a tensão $\sigma_{3}$ passa de compressiva para tracional, acarretando o fendilhamento paralelo à super ficie topográfica. 
ra. A Fig.2.14 mostra como aparecem essas juntas e como se justi ficam pelo grä́fico de Mohr.

Alëm desse tipo de junta, pode ser ainda citada a junta de resfriamento, originada na consolidação de rochas vulcânicas de gran fina como os basaltos; essas juntas são em geral quase "soldadas", desempenhando um reduzido papel como conduto e arma zenamento da água.

2.3.2. UTILIZACGAO DOS PARAMETROS LITO-ESTRUTURAIS NA LOCACAO DE POCOS

\section{$2.3 .2 .1-$ Constituicão 1 itolögica}

A influência do tipo 1itolögico na quantidade de àgua infiltrada e armazenada diz respeito as suas propriedades físi cas, que determinam a intensidade de fraturamento e o grau de $\underline{a}$ bertura entre as superficies de fraturas.

De acordo com a mecânica das rochas, quanto mais compe tentes as rochas, menor a intensidade de fraturamento, mas em compensação, mais abertas são as fraturas nelas existentes. As sim, um gnaisse por exemp10, possui menor intensidade de fratura mento do que um micaxisto, porém no primeiro as fraturas são mais abertas do que no segundo. Tambëm a orientação da rocha influi na sua potencialidade hidrica, pois nas rochas orientadas como os paragnaisses, desenvolvem-se mais planos de fraturamento do que nas não orientadas, como o granito e nas primeiras, são melhores as condiçōes quando a orientação $\vec{e}$ planar do que linear, como nos ortognaisses.

Por outro lado, a granulação dos cristais também exerce influência, pois quanto maiores e mais desenvolvidos (o pegmati to p.e.) mais quebradiça é a rocha, enquanto nas rochas de granu lação fina (granito fino p.e.) a resistência ao quebramento é mator.

Uma outra situação litológica favorável é a do contato entre duas unidades petrográficas distintas, como seja, entre um 
granito e um micaxisto, ou entre um migmatito e um quartzito, dentre outros tipos.

Quanto ’a qualidade da ảgua, a influência pode ser consi deráve1, pois alëm da participação da abertura no processo de in filtração, circulação e salinização da ägua, ocorrem ainda disso luções que acarretam ou aumentam a salinizaça das águas.

\section{3 .2 .2 - Estruturas geolögicas favoräveis}

As estruturas geológicas constituem o principal fator que atua na quantidade de água armazenada no aquifero fissural, desempenhando paralelamente um certo papel, tambëm na qualidade da ägua.

Conforme ja foi visto, as estruturas mais favoraveis são aquelas representadas por rupturas do maciço sob efeito de: esforcos tracionais; as falhas e as fraturas tracionais (tipo ac e bc de SANDER) alëm daquelas de alívio de pressão são as mais favorảveis para acumulação da àgua.

Quanto as runturas por cisalhamento, que tanto podem a carretar falhas do tipo transcorrente, como simples fraturas lon gitudinais ou angulares (tipos hk0 ou h01 de SANDER) são em ge ral desfavoräveis para a locação do poço, pois as suas aberturas são muito reduzidas, chegando mesmo a serem regeladas.

Os planos de descontinuidade original das rochas meta mórficas, como a xistosidade dos micaxistos ou a clivagem das ardósias, tambẻm desempenham uma certa importância, principalmen te quando associados às estruturas naturais, aumentando-1hes a intercomunicação e, consequentemente, a permeabilidade do maciço rochoso. A percolação da ägua ao longo desses planos de desconti nuidade original se faz muito lentamente, muitas vezes por for ças capilares, mas desempenham importante papel nos processos de decomposição quimica, sendo muito comum encontrar-se as superfí cies desses planos, completamente oxidadas ao serem quebrados e destacados.

A associação do diaclasamento com o dobramento e as des continuidades, desempenha importante papel na locação do poço. Assim, as estruturas dobradas decorrentes de esforços compress 
vos de elevada intensidade, acarretando mergulhos dos flancos das dobras, com ângulos superiores a $60^{\circ}$ são em geral desfavorâa veis, pois em tais situações, as rochas adquirem maior plastici dade e menor desenvolvimento ruptural, além de possuirem planos mais fechados de descontinuidades originais. Ao conträrio, os dobramentos cujos flancos apresentem ângulos de mergulhos infe riores a $30^{\circ}$, propiciam maiores aberturas em fraturas longitudi nais (tipo bc de SANDER) e maiores possibilidades ao longo dos planos de descontinuidade originais.

$\mathrm{Na}$ Fig.2.15, a situação em $\mathrm{A}$ apresenta uma boa possibili dade de acumulação de água nas diăclases longitudinais e planos de xistosidade ou de clivagem; em $B$ a situação e apenas regular e em $\mathrm{C}$ a situação hidrogeolögica è desfavorável.

Uma outra aplicação da associação dobramento-diaclasa mento, é quando dos eixos de dobras dispostos em leque (estrutu ra conhecida como "rabo de cava10"): nas proximidades do vértice do leque as fraturas longitudinais são fechadas. Assim, na Fig. 2.16,a ärea (3) apresenta muito melhores condições de locação de poço do que a área (2), enquanto nesta, a situação é melhor do que na área (1).

Alêm do problema jâ discutido no item anterior, com re lação a abertura das fraturas longitudinais paralelas ao eixo das dobras e da participação dos planos de xistosidade e clivagem nas dobras de maior intensidade, outros aspectos devem ser considerados relacionados ao pröprio mergulho dos planos de fra tura.

Dois problemas devem ser levados em consideração, quan do se analisa a importância do mergulho dos planos de fratura: - nümero de fraturas interceptadas pelo poço e a abertura das fraturas.

Quanto ao primeiro aspecto, de quantidade de planos de fratura que possam ser interceptados por uma perfuração de poço, é evidente que, quanto mais suave for a inclinação desses planos, maiores as possibilidades de se obter água pelo aumento do nüme ro de fraturas interceptadas.

Admitindo um mergutho constante de um conjunto de fratu ras segundo uma só direção, suponha-se, para efeito de comparação, três situações distintas, com mergulhos de $20^{\circ}, 45^{\circ}$ e $70^{\circ}$, supon 


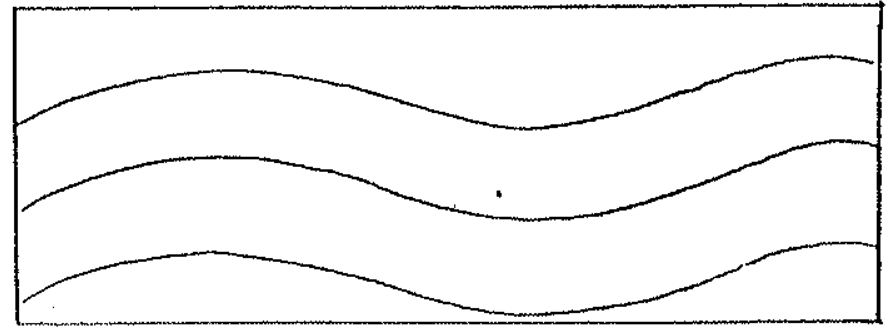

A

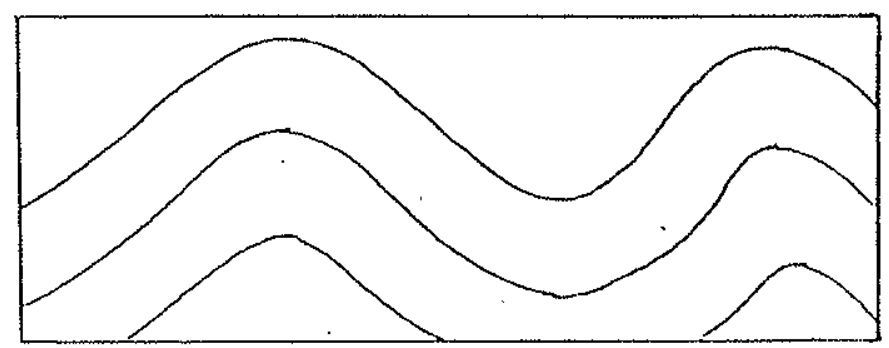

B

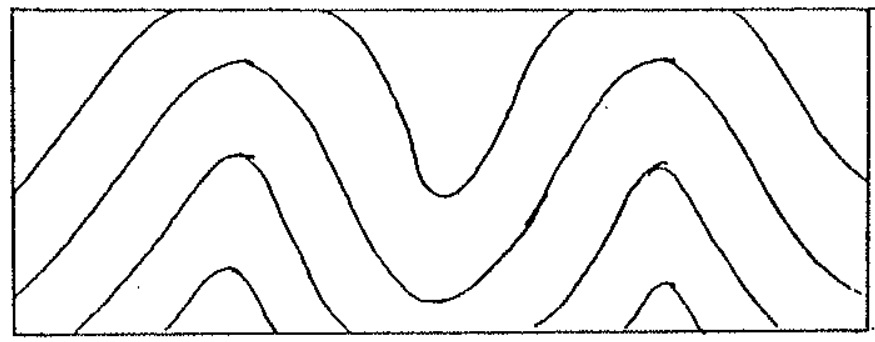

C

FIG.2.15- Diferentes situaçöes de mergulho de planos de xistosidade

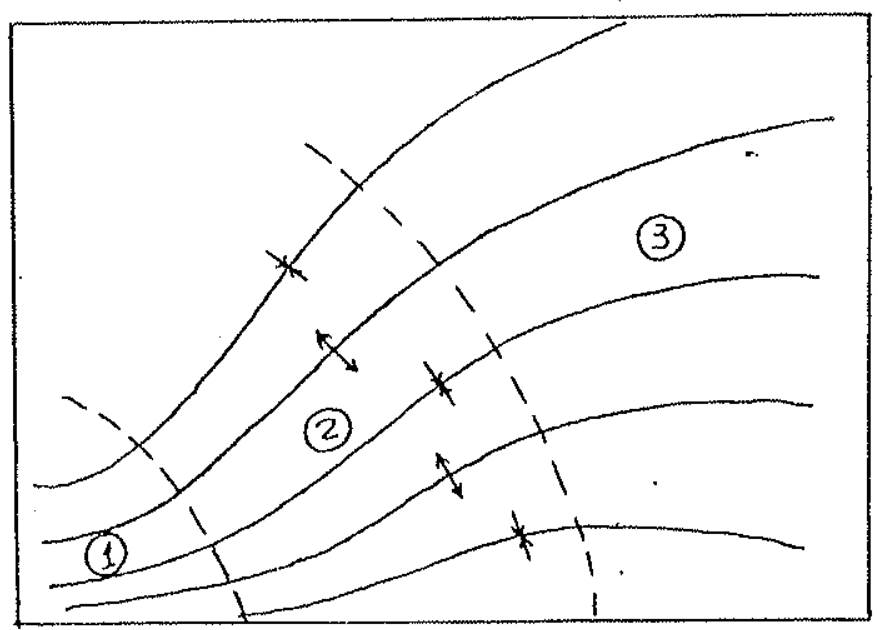

FIG.2.16- Disposição em leque dos eixos de dobras 
do ainda que a intensidade de fraturas seja a mesma nos três ca sos, ou seja, com afastamento de $1 \mathrm{~m}$ entre cada fratura. Observa -se na li. 2.17, que em $\Lambda$, com fraturas mergulhando de $20^{\circ}$, um poco interceptaria 6 (seis) fraturas atê a profundidade de $70 \mathrm{~m}$; na si tuação B., com fraturas mergulhando de $45^{\circ}$, somente duas fraturas foram interceptadas (podendo chegar até 3 a depender do local do poço); na situação $\mathrm{C}$, com fraturas de $70^{\circ}$ de mergulho, apenas $\underline{u}$ ma fratura foi interceptada, podendo inclusive não interceptar nenhuma, a depender da locação do poço.

No que se refere ao segundo aspecto, de abertura das fraturas, conforme foi visto, as fraturas de tração, tipo ac de SANDER, são em geral sub-verticais. Desse modo, constata-se que muitas vezes $\vec{e}$ melhor interceptar um menor nümero de fraturas, porêm com maior abertura do que um maior numero com menores aber turas. A situação ideal todavia, è aquela em que uma fratura prin cipal de forte mergulho estä associada a fraturas secundärias de menor intensidade, e que numa perfuração se possa atingir simu1 tâneamente os dois tipos.

A associação estrutura-hidrografia $\vec{e}$ de grande importân cia pois estabelece a relação entre a condição da existência de um reservatōrio natural e a alimentação desse reservatório.

SIQUETRA(1963) introduziu o termo "riacho-fenda" para caracterizar essa associação, significando o termo, a condição em que determinados trechos de um riacho são alinhados segundo direçöes coincidentes com estruturas fendilhadas. Nessa situação, a fenda (ou fratura) seria alimentada periodicamente, sempre que o riacho estivesse com escoamento superficial.

Essa relação vem sendo utilizada com frequência na loca ção de poços em rochas fraturadas e permite, a partir de observa ções locais, com medições do ângulo de mergulho das fraturas, a quilatar com boa aproximação, a profundidade em que deverä ser interceptada a fratura principal, objeto da recarga fluvial.

A Fig. .18 mostra uma seção vertical com $50 \mathrm{~m}$ de distância horizontal (na superfície) por $100 \mathrm{~m}$ de profundidade (na sub-su perfície); no vërtice superior esquerdo, encontra-se um riacho que alimenta fraturas de diferentes intensidades de mergulho(de $10^{\circ}$ a $80^{\circ}$ ). Verifica se que, ate a profundidade de $100 \mathrm{~m}$, a fratu ra de $80^{\circ}$ somente é interceptada a $10 \mathrm{~m}$ de distância da zona de 

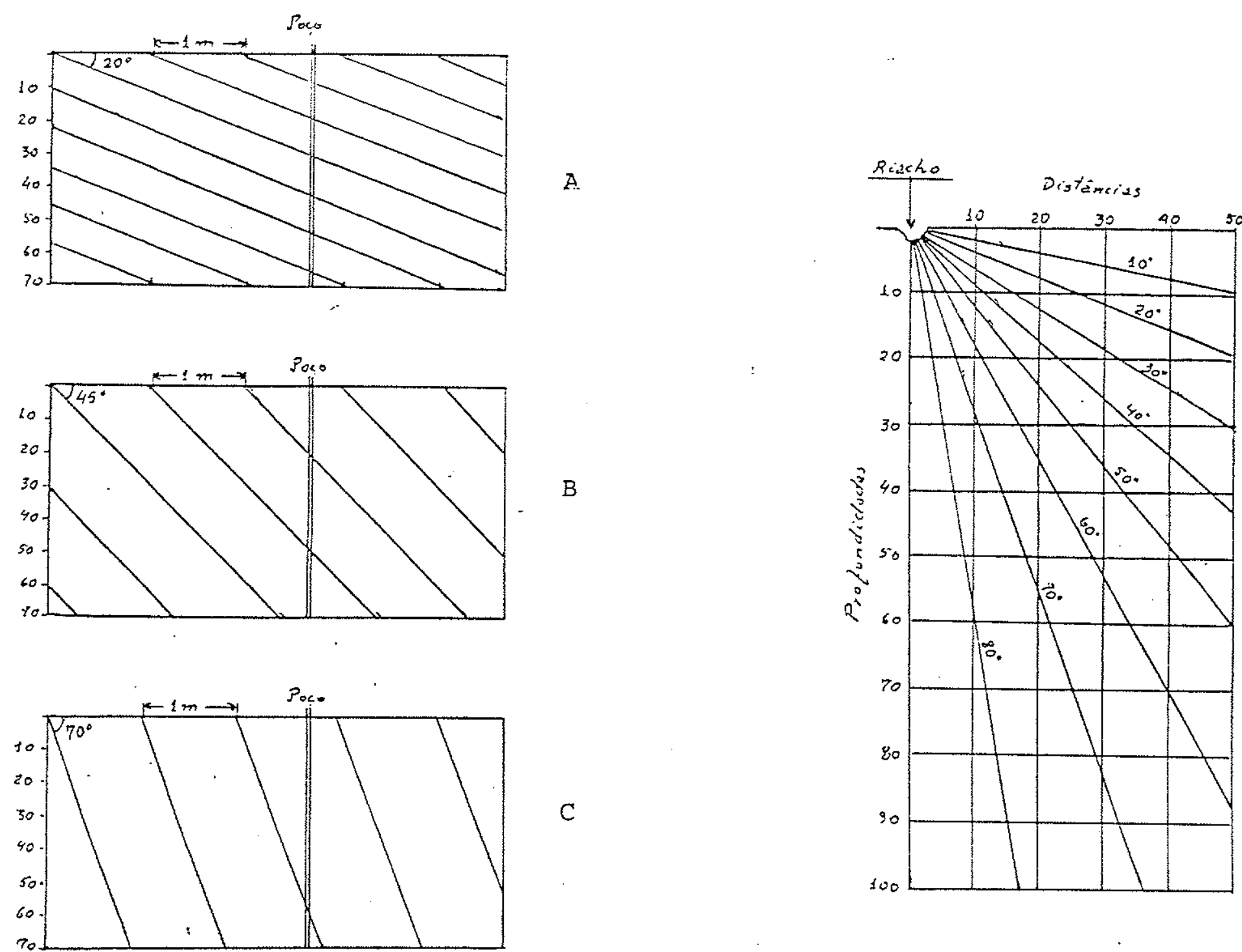

FIG. .17-Relação entre o ângulo de mergu tho e a interseção de fraturas num poço

FIG .18 - Relação entre distância da ärea de recarga e a profundidade de in terseção da fratura pelo poço. 
alimentação e a de $70^{\circ}$ è interceptada atẻ aos $30 \mathrm{~m}$ de distância. 0 cälculo da profundiclade de interseção de uma fratura qualquer, conhecido o ângulo de mergutho do plano de fratura e a distância onde será perfurado o poço, pode ser efetuado fácil mente atravês da seguinte expressão matemática:

em que:

$$
\mathrm{p}=\mathrm{d} \cdot \operatorname{tg} \alpha
$$

$\mathrm{p}=$ profundidade de interseção da fratura no poço

$\mathrm{d}=$ distância do poço ao riacho (zona de recarga)

$\alpha=$ ângulo de mergulho da fratura

\section{3 .2 .3 - Situasões comumente ocorrentes nos pocos}

De um modo geral, seis condicões devem ser consideradas para se conseguir êxito na perfuração do poço em rochas cristali nas, quais sejam:

- existência de fraturamento na rocha

- grau de abertura das fraturas

- extensão e profundidade das fraturas

- Erequência do fraturamento

- interconexão das fraturas

- conexão do sistema de fraturas com zonas de recarga na superfície (rios, lagos, capeamento permeável,etc)

A combinação dessas condições, o grau de favorabilidade de cada um e a frequência de ocorrência dos diferentes casos,per mite uma caracterização de 10 (dez) situações distintas, confor me anälise elaborada por COSTA(1980), a partir de estudos ante riores de JEGRAND(1959) e CAMPBEL(1977) e a seguir descritos (com ilustração na Fig.2.19).

Caso A - o poço não penetra fraturas abaixo do revesti mento (de apenas $15 \mathrm{~m}$ ); nesse caso o poço será seco.

Caso B - o poço penetrou numa zona fraturada em que 2 (duas) ou mais fraturas ocorrem a poucos metros abaixo do reves timento; $\vec{e}$ um tipo muito comum de poço. Ele pode produzir vazöes de 2 a $4 \mathrm{~m}^{3} / \mathrm{h}$ durante vários minutos, até as fraturas serem dre nadas. Sua vazão declinarâ subitamente para uma fração do seu valor total, dependendo a estabilização, da permeabilidade do 
manto de cobertura. A parte do poço abaixo da zona de fratura, não contríbui. com água e atua somente como reservatório. A vazão desse poço não aumenta quando aumenta o rebaixamento. o mais efi ciente nível de bombeamento, e provavelmente, poucos decímetros abaixo da zona de fraturamento.

Caso C - o poço penetra apenas uma fratura, bastante ex tensa e bem abaixo, a uma profundidade de $65 \mathrm{~m}$ (aproximadamente). Como o caso B, a perenização da vazão dependerä da permeabilidade do manto de cobertura e da capacidade de transmitir da fratura. Se a âgua é retransmitida do manto para a fratura tão rapidamen te quanto é transmitida atravês da fratura para o poço, a vazão aumentará com o aumento do rebaixamento, até o nível d'ägua a1 cançar a fratura contribuinte. Não haverá aumento da vazão abai xo desse nível de bombeamento (ao nível da fratura). Porém, se a água $\vec{e}$ fornecida do manto para a fratura com velocidade menor do que aquela que é transmitida atravês da fratura, o nível de bom beamento mais eficiente será numa posição intermediäria entre a fratura e a base do manto.

Caso D - o poço penetra apenas uma fratura a grande pro fundidade $(\approx 65 \mathrm{~m})$, de boa abertura, porêm com extensão limitada, com precāria ou difusa comunicação com o manto. Assemelha-se ao caso $C$, porém apresenta em geral uma pseudo-estabilização do re baixamento durante o bombeamento, devido a presença de um "eleva do" volume de água na fratura; a medida que a àgua vai sendo es gotada e a realimentação se faz com dificuldade, recai-se no ca so anterior, pela segunda alternativa, necessitando portanto si tuar-se o nivel de bombeamento numa posição intermediäria entre a fratura e a base do manto. Esse caso induz, muitas vezes,a er ros no dimensionamento da bomba a utilizar, quando o teste $\bar{e}$ fei to em curto período de tempo.

Caso E - o poço penetra vārias fraturas, contribuindo com pequenas quantidades de âgua, e uma grande fratura à maior profundidade $(50 \mathrm{~m}$ p.e.). A vazão irá aumentar com o aumento do rebaixamento, ate atingir a zona de maior contribuição (no caso, aos $50 \mathrm{~m})$. O mais eficiente nível de bombeamento serä provavelmen te logo acima da posição em que o poço penetrou a maior fratura.

Cas.o F - o poço penetrou värias fraturas de tamanho pe 
queno a mëdio. Estas fraturas são mais amplas e mais próximas $\underline{u}$ ma das outras (maior frequência), na parte superior da rocha fra turada. para una vazão estabilizada, a bomba pode ficar entre 10 a $20 \mathrm{~m}$ abaixo do topo da rocha inalterada (bedrock).

Caso G - o poço penetrou duas ou três fraturas de boa abertura e pequena extensão, saturadas, alimentadas por fraturas pequenas a médias (em abertura) que se comunican com o manto de cobertura. Nesse caso, o poço apresenta o fenômeno que ocorre no caso $\mathrm{D}$, porëm com consecutivas quedas de rebaixamento, a medida que cada uma das fraturas abertas vai se esgotando com o bombea mento. Os poços tendem a fornecer no início da exploração, boas vazões, caindo com o tempo, que pode ser maior ou menor em função da amplitude das fraturas, distância para a zona de realimen tação e dificuldades de realimentação das fxaturas secundārias. o nível ideal de bombeamento é logo acima da fratura (dentre as abertas) mais superior, pois a partir daí, uma vez estabilizada a vazão, não haverā aumento de vazão com o aumento do rebaixamen to.

Caso H - o poço penetra em värias fraturas de boa aber tura, 1 igadas ao manto, porem preenchidas por material detriti co. A caracteristica principal do poço é o contínuo desenvolvi. mento, a medida que se prolonga o bombeamento, devido a desobs trução gradativa das fraturas. O processo de desenvolvimento na tural pode ser ativado com um "plungeamento" logo apös a perfú ração do poço. Em geral, são poços de boa produção. A vazão au menta quando aumenta o rebaixamento e o nivel de bombeamento po de ficar numa posição intermediäria entre as primeiras e as $\underline{u} 1$ timas fraturas penetradas.

Caso I - o poço é influenciado por uma falha nas proxi midades, atravessando värias fraturas. A falha atua como uma fronteira impermeáve1, pois quebra abruptamente a continuidade das fraturas que alimentam o poço, provocando o efeito de deple ção durante o bombeamento. No mais, apresenta um comportamento semelhante ao caso G, quanto ao posicionamento do nivel de bom beamento.

Caso $J$ - o poço $\vec{e}$ influenciado por uma fonte perene de recarga superficial. Esse ê o caso mais favorävel para obtenção 
de una boa vazão en rocha fraturada. O nî̀vel dinâmico é estabi lizado com rapidez e, deyido a interconecção do sistema de fra turas, o nîvel de bombeamento pode descer até a proximidade da fratura principal, que recebe a contribuição da ägua superfici al.
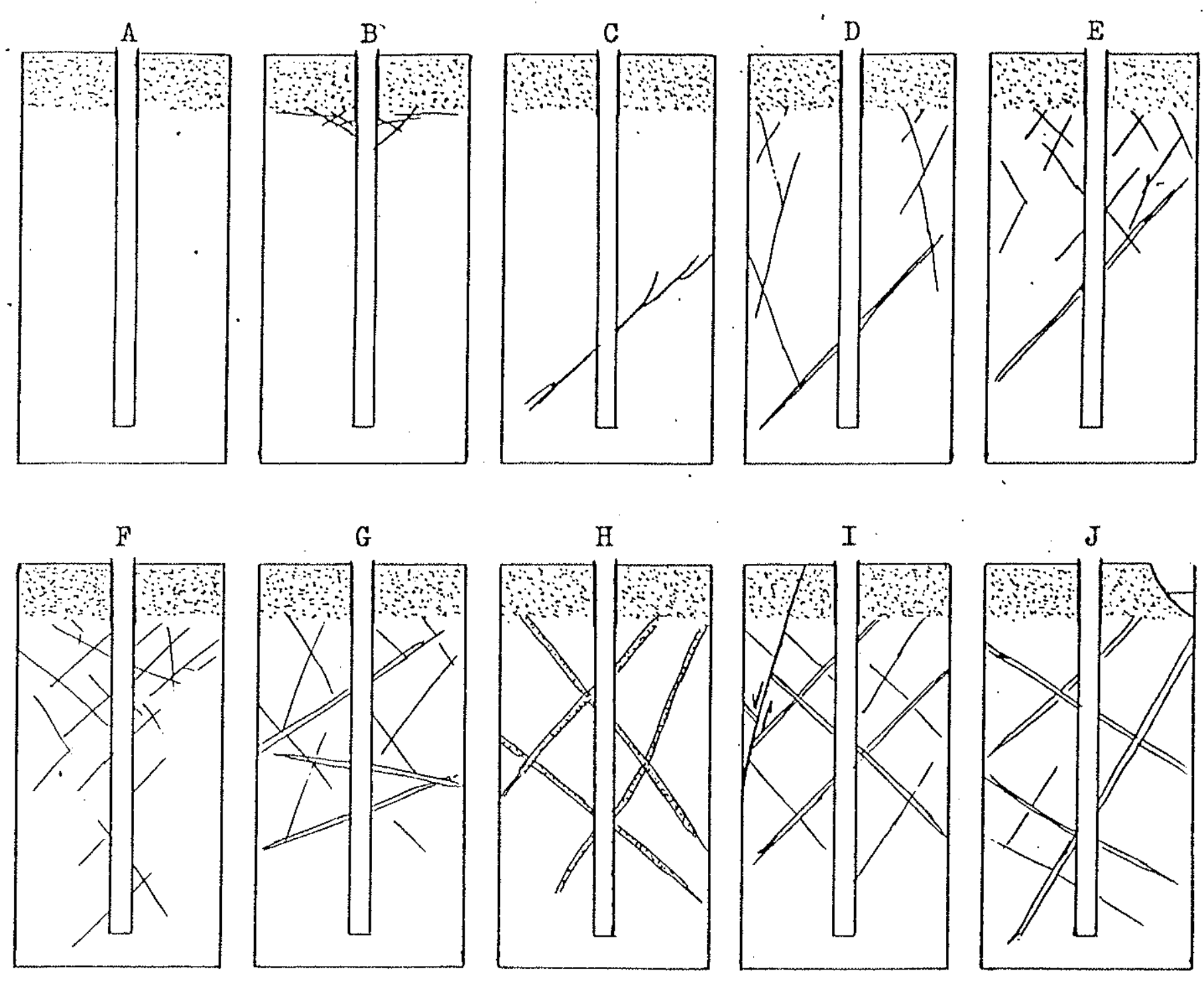

FIG.2.19- Diferentes situações encontradas na perfuração de um poço em rocha cristalina fraturada. A profundidade total é de 80m (aprox.), com $15 \mathrm{~m}$ de revestimento (no manto de decomposição, pontilhado nas figuras). Os casos A e J representam as condições extremas de exploração; no primeiro o poço será sêco e no segundo, as condições de explorração são as melhores. (Adaptação de LEGRAND,1959 e CAMPBELI; 1977). 
CAPITULO NO 3

DINAMICA DO FLUXO FMM FRATURAS 
3.1. INTRODUCAO

Como meio fissurado entende-se o maciço rochoso com super fícies de descontinuidade provocadas por esforços compressivos ou tracionais. Esse meio, quando possui as suas aberturas, denomina das fissuras, fraturas, juntas ou diäclases ou mesmo paräclases (falhas), preenchidas por ägua, constitui o aquífero fissural.

A circulação de āgua que se infiltra nessas fissuras é atualmente estudada sob dois aspectos: quanto a seu aproveitamen to como recurso hídrico, para exploração atravẻs de poços, que a bastecerão núcleos habitacionais urbanos ou rurais; ou, em função dos problemas que a ägua acarreta em obras de engenharia, como tú neis, fundações de barragens, etc.

o campo de estudo do primeiro aspecto, do uso benéfico da ảgua subterrânea, è a hidrogeologia, comumente designada de "hi drogeologia de rochas cristalinas" ou "hidrogeologia de rochas du ras fraturadas" dentre outras. Quanto ao segundo aspecto, dos ma lefícios provocados pela ảgua subterrânea, diz respeito ao campo da hidrogeotecnia.

Os aspectos teöricos da circulação da āgua no meio fissu rado, são comuns a ambos os campos de estudo, diversificando ape nas no que tange aos métodos de exploração na hidrogeologia ou de estanqueidade na hidrogeotecnia.

os elementos fundamentais da hidrodinâmica devem ser le vados em conta, assim como as características físicas do meio, a fim de se poder entender as leis de escoamento nas fissuras.

\subsection{CONCEITOS HTDRAULICOS FUNDAMENTAIS}

o fluxo da água no meio fissurado é regido por leis hi dräulicas do mesmo modo que o são os escoamentos em tubudaçõés ou em meios porosos.

Assim, será a seguir procedida uma revisão dos conceitos hidräulicos fundamentais e, sempre que necessärio, estabelecidas as relações e distinções de caracteristicas entre os diversos meios. 
3.2.1. REGTMES DE ESCOAMENTO (OU DE FLUXO)

A observação dos fluidos em movimento leva a distinguir dois tipos de rëgimes: laminar e turbulento.

No regime laminar, cada partícula descreve uma trajetória bem definida, com velocidade apenas no sentido do escoamento. 0 fluxo laminar ocorre em camadas, sem mistura das partículas do $1 \underline{i}$ quido e sem variação de velocidade. Nesse caso, todas as Iinhas de fluxo se determinam pela forma do conduto pelo qual f1ui o fluido; não ocorrem deslocamentos transversais das partículas, não havendo mistura no processo de escoamento. Um piezômetro ins talado num conduto com fluido em regime laminar de escoamento, in dica pressão constante e ausência de oscilações.

O fluxo turbulento é caracterizado pela mistura interna do fluido e oscilações de velocidades e pressões. Alëm da veloci dade no sentido do escoamento, as partículas estão animadas de movimento de agitação, com velocidades transversais ao sentido do escoamento.

Entre esses dois tipos de movimento, interpõe-se um ter ceiro, de transição, que representa a passagem de um regime de escoamento para outro.

A mudança de regimes de fluxo ocorre numa velocidade que se denomina velocidade crítica, $v_{\mathrm{cr}}$. A velocidade critica superi or é aquela acima da qual o fluxo é sempre turbulento. A veloci dade critica inferior é aquela abaixo da qual o fluxo è sempre laminar.

o parâmetro que caracteriza essa mudança de velocidades $\vec{e}$ o nümero de Reynolds,

$$
R_{e}=\frac{v \cdot D H}{v}
$$

onde: $\quad V=$ velocidade mëdia $(\mathrm{cm} / \mathrm{seg})$

$\mathrm{DH}=$ diâmetro hidräulico $(\mathrm{cm})$

$\nu=$ viscosidade cinemâtica do fluido (relação entre a viscosidade absoluta e a densidade do fluido)

Nas experiências de Reynolds, para avaliar os limites en tre os regimes de escoamento de um 1 íquido atraves de um tubo,e le fez variar a velocidade, desde que as grandezas DH e $v$ são 
constantes, e concluiu que, para $R e=12.000$, o regime laminar passava para o regime turbulento dentro do tubo (STREETER, 1974). Em BENEDINI et alii(1972), é apresentada uma classifica ção, atribuida a Chauvetau e Thirriot, para caracterizar o movi mento de um fluido em meio poroso:

19 - zona na qual o movimento é laminar e a lei de Darcy é completamente verificada $(\operatorname{Re}<2)$

29 - zona na qual o movimento é ainda laminar, porém de formado pela força de inércia $(2<\operatorname{Re}<80)$

$3^{\circ}$ - zona na qual o movimento é ainda laminar em certo ponto e turbulento em outro $(80<\operatorname{Re}<180)$

4 - zona em que o movimento $\vec{e}$ somente turbulento $(\operatorname{Re}>180)$.

A passagem do fluxo laminar ao turbulento é muito maior ( o Re) num tubo liso do que num meio poroso (2.500 no primeiro, contra 180 no segundo).

\subsubsection{Fluxo 1aminar - Lei de Hagen-Poiseuille}

Esta lei foi estabelecida para o caso de fluxo em condu to de seção circular constante. A velocidade nas paredes è nuIa e alcança o seu mäximo no eixo do conduto (SCHLICHTING, 1960). A plicando-se essa 1 ei ao caso de fluxo entre duas placas paralelas obtem-se a lei de escoamento, vảlida para um conduto de seção transversal retangular, em que a largura das placas ê muito maior do que a sua abertura.

Considere-se o caso de fluxo laminar entre duas placas pa ralelas perfeitamente polidas, afastadas entre si de uma distân cia e (Fig.3.1). Imagine-se dojs planos verticais, separados por uma distância $\ell(A-A$ e $B-B)$ e uma largura de escoamento unitária $b=1$. Isolando um volume prismätico de dimensōes $p \times 2 y \times 1$ cu jo eixo coincide com o eixo dos $x$ e aplicando a condição de equi Iíbrio, vem:

$$
\left(p_{1}-p_{2}\right) 2 y \cdot \ell=\zeta .2 \$ \mathrm{r} \ell .1
$$

sendo $p_{1}-p_{2}$ a diferença de pressão entre as faces do prisma. 
Pela lei do atrito de Newton,

$$
\begin{gathered}
\zeta=-\mu \frac{\mathrm{dv}}{\mathrm{d} y} \\
\mathrm{dv}=-\frac{\mathrm{p}_{1}-\mathrm{p}_{2}}{\mu \cdot l} \text { e } \quad \mathrm{v}=-\frac{\mathrm{p}_{1}-\mathrm{p}_{2}}{2 \mu l} \mathrm{y}^{2}+\mathrm{C}
\end{gathered}
$$

para $y=e / 2, \quad v=0$

$$
C=\frac{p_{1}-p_{2}}{2 \mu \ell} \cdot \frac{e^{2}}{4} \quad \text { e } \quad V=\frac{p_{1}-p_{2}}{2 \mu \ell}\left(\frac{e^{2}}{4}-y^{2}\right)
$$

sendo $d Q=v \cdot d A$ a vazão elementar, vem

$$
\mathrm{d} Q=\frac{\mathrm{p}_{1}-\mathrm{p}_{2}}{2 \mu \ell}\left(\frac{\mathrm{e}^{2}}{4}-\mathrm{y}^{2}\right) \cdot 2 \mathrm{dy}
$$

e,

$$
\begin{aligned}
& Q=\frac{p_{1}-p_{2}}{\mu \cdot \ell} \int_{0}^{e / 2}\left(\frac{e^{2}}{4}-y^{2}\right) d y \\
& Q=\frac{g \cdot e^{3}}{12 \nu} \cdot \frac{p_{1}-p_{2}}{\ell}
\end{aligned}
$$

onde,

$$
v=\frac{\mu}{g}
$$

sendo g a aceleração de gravidade.

A velocidade máxima ocorre no eixo do conduto para a con dição de $y=0$.

Fazendo $V=Q / A$, obtém-se o valor da velocidade mëdia,

$$
V=\frac{g \cdot e^{2}}{12 \nu} \cdot \frac{p_{1-p_{2}}}{\ell}
$$

Como:

$$
\begin{aligned}
& \mathrm{p}_{1}-\mathrm{p}_{2}=\Delta \mathrm{H}, \text { vem: } \\
& \mathrm{V}=\frac{\mathrm{g} \cdot \mathrm{e}^{2}}{12 \nu} \cdot \frac{\Delta \mathrm{H}}{\ell}
\end{aligned}
$$

A relação entre $\lambda$ e Re pode ser obtida a partir da defi 
nição do diâmetro hidrăulico para o fluxo entre duas placas para lelas.

$$
\begin{aligned}
& \text { O diâmetro hidrāulico é definido pela relação, } \\
& D H=4 \mathrm{RH}=4 \mathrm{~A} / \mathrm{P},
\end{aligned}
$$

onde $\mathrm{RH}=$ raio hidräulico, $\mathrm{A}, \vec{e}$ a área perpendicular ao senti do de escoamento e $\mathrm{P}$ o perímetro ao longo do qual se estabelece o atrito viscoso nas paredes do conduto. Portanto,

$$
\mathrm{DH}=4 \frac{\mathrm{e} \cdot l}{2 \cdot l}=2 \mathrm{e}
$$

substituindo em (8), vem:

$$
v=\frac{\mathrm{g} \cdot \mathrm{DH}^{2}}{48 v}\left(\frac{\mathrm{p}_{1^{-}} \mathrm{p}_{2}}{\ell}\right)
$$

ou:

$$
\frac{p_{1}-p_{2}}{\ell}=\frac{96}{D^{2}} \cdot v \frac{v^{2}}{2 g}
$$

Considerando-se a equação da perda de carga, de Darcy e Weisbach, bem como o nümero de Reynolds, obtém-se:

$$
\lambda=\frac{96}{\operatorname{Re}}
$$

Expressão que representa a lei de escoamento para fluxo laminar entre duas placas paralelas de abertura constante e per feitamente polidas. Para fluxo em condutos de seção transversal circular, constante,

$$
\lambda=\frac{64}{\operatorname{Re}}
$$

A Fig.3.2, mostra uma comparação entre essas duas leis, välidas apenas para fluxo laminar. 


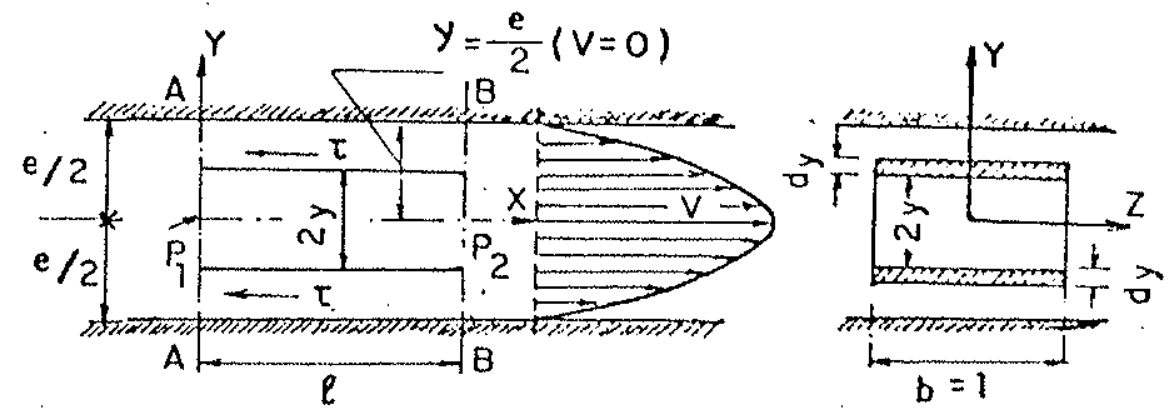

FIG.3.1-Fluxo entre duas placas paralelas perfeitamen te polidas (idea1). (QUADROS/1982)

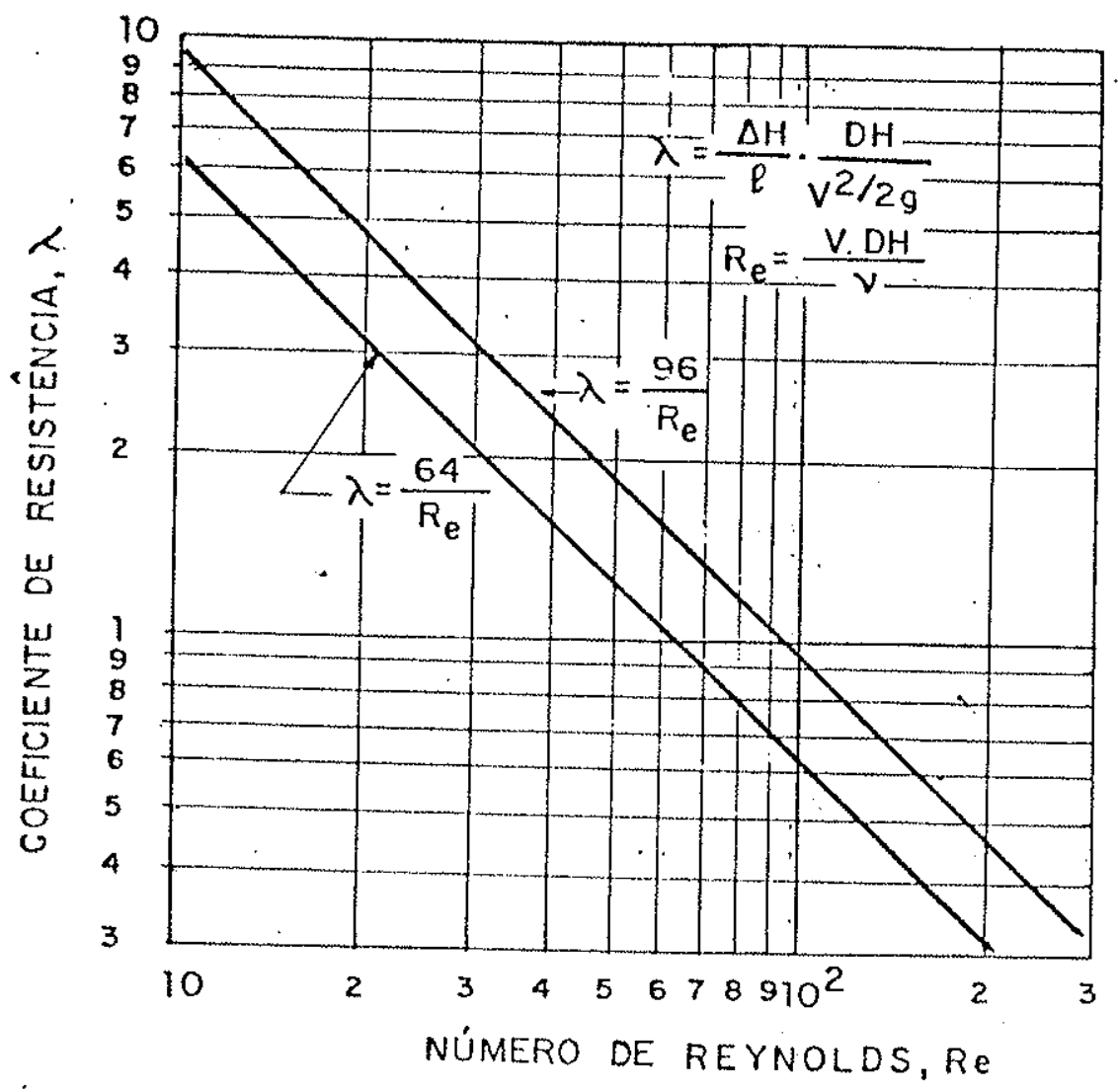

FIG.3.2-Gräfico mostrando a relação entre as leis de escoamento para fluxo laminar entre placas paralelas e em condutos de seção transversal circular constante. (QUADROS, 1982) 


\subsubsection{Fluxo turbulento}

Devido à pröpria natureza do fluxo turbulento, o perfil de velocidades è muito mais uniforme no fluxo turbulento do que no fluxo laminar. A Fig.3 5 mostra essa distribuição de velocida des para uma mesma massa flüida e conduto de seção circular cons tante (SCHLICHTING, 1960).

o valor crítico acima do qual o fluxo é sempre turbulen to $\vec{e}$ aproximadamente,

$$
\operatorname{Re}_{\mathrm{c}}=2.300
$$

As perdas de carga no regime turbulento são diferentes daquelas que ocorrem no regime laminar e são consideravelmente maiores para as mesmas dimensões, vazão e viscosidade. No fluxo turbulento predominam as perdas de carga por mistura e transfe rência de quantidades de movimento, enquanto que no fluxo lam $\vec{i}$ nar predominam as perdas de carga por atrito viscoso entre as camadas.

3.2. 2. LEY DE DARCY - LIMITE DE VALIDADE

3.2.2.1- Lei de movimento de Darcy

Darcy estabeleceu que a descarga através de uma coluna de areia ë proporcional à ärea total (A) e ao gradiente hidräu lico $(\mathrm{I}=\Delta \mathrm{H} / \mathrm{L}) \cdot 0$ coeficiente de proporcionalidade $(\mathrm{K})$ è a condutividade hidráulica.

$$
Q=K \cdot A \cdot I=K \cdot A \cdot \frac{\Delta H}{L}
$$

A descarga por unidade de ärea è a descarga específica ou fluxo especifico (q)

Considerando uma coluna sölida elementar na direção $\underline{s}$ conforme esquema que se segue, pode-se escrever a lei de Darcy da seguinte maneira: 


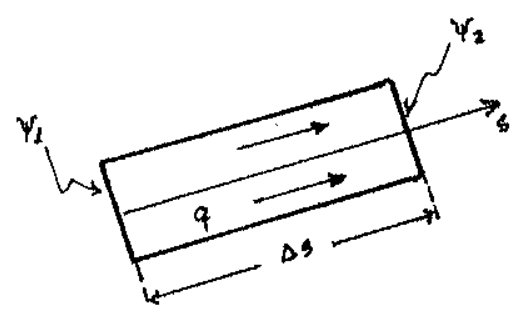

$$
q=K \cdot I=K \frac{\Delta \Psi}{s}
$$

A forma diferencial da Lei de Darcy, obtida para $\Delta s \rightarrow 0$, será:

$$
q=\lim _{\Delta s \rightarrow 0} K \frac{\Psi_{1}-\Psi_{2}}{\Delta s}=-\lim K \frac{\Psi_{2}-\Psi_{1}}{\Delta s}=-K \frac{\partial \Psi}{\partial s}
$$

Multiplicando a equação (16) por um vetor unitärio $\overrightarrow{\mathrm{s}}$ na direção s, obtem-se a forma vetorial da Lei de Darcy:

$$
\overrightarrow{\mathrm{q}}=-K \cdot \nabla \Psi
$$

No espaço tridimensional $(x, y, z)$ os componentes do vetor descarga específica, são:

$$
q_{x} \vec{I}+q_{y} \vec{j}+q_{z} \vec{k}=-k\left(\frac{\partial \psi}{\partial x} \vec{i}+\frac{\partial \psi}{\partial y} \vec{j}+\frac{\partial \psi}{\partial z} \vec{k}\right)
$$

\subsubsection{Condutividade hidräulica e Permeabilidade}

A condutividade hidráulica $K$ (dimensão $\mathrm{LT}^{-1}$ ) é uma fun ção do solo(rocha) e propriedades dos fluidos e pode ser expres sa através de:

$$
K=\frac{k y}{\mu}=\frac{k \rho g}{\mu}=\frac{k g}{\nu}
$$

A permeabilidade $\mathrm{k} \overrightarrow{\mathrm{e}}$ uma propriedade intrínseca da matriz sölida enquanto a viscosidade cinemātica $(\nu)$ é uma função da pressão e temperatura.

Considerando que a ägua possui $\gamma=1 \mathrm{gr} / \mathrm{cm}^{3}$ e $\mu=1 \mathrm{cp}$, conclui-se que para esse fluido, a condutividade hidräulica é e quivalente à permeabilidade, ou: $K \cong \mathrm{k}$. 
A permeabilidade ( $k$ ) pode ser relacionada ao diâmetro do grão (d) e à porosidade (m), pela fórmula de Kozeny-Carman ( in COSTA, 1980):

$$
k=d^{2} f \cdot \frac{m^{3}}{(1-m)^{2}}
$$

sendo $f$ um parâmetro que depende da forma do grão e da tortuosidade.

As unidades usadas para $K$ são usualmente $\mathrm{m} / \mathrm{dia}, \mathrm{m} / \mathrm{s}$ ou $\mathrm{cm} / \mathrm{s}$, enquanto para $k$, a unidade mais usada é o darcy

$$
1 \text { darcy }=9,896 \cdot 10^{-9} \mathrm{~cm}^{2}
$$

\subsubsection{Validade da Lei de Darcy}

O relacionamento linear entre $|\vec{q}|$ e $|\nabla \Psi|$ (forma vetorial da Lei de Darcy (Eq.12) é vảlido somente para nümero de Reynolds entre $I$ e 10, conforme mostra a Fig 3.4 (segundo BRAESTER,1977). No fluxo através do meio poroso, o diâmetrôtao grão (d) é escolhi do como comprimento característico e a descarga específica(q) as sume o papel da velocidade no nümero de Reynolds, que passa a ser expresso por:

$$
\operatorname{Re}=\frac{\mathrm{qd}}{v}
$$

\subsection{CARACTERISTICAS GEOMETRICAS DO MEIO FISSURADO}

3.3.1. COMPORTAMENTO HIDROGEOLOGICO DO MEIO

$\mathrm{Na}$ hidrogeologia de rochas cristalinas, ē de fundamental importância o conhecimento dos processos que deram origem às de formações e das caracteristicas físicas das rochas que foram afe tadas por essas deformações, sobretudo do tipo ruptural.

As rochas reagem diferentemente aos esforços, produzindo diferentes tipos de fraturas, com abertura, extensão e intensida de (frequência) variäveis; por outro lado, os tipos de esforços tambëm diversificados, podem produzir diferentes tipos de defor mações. 


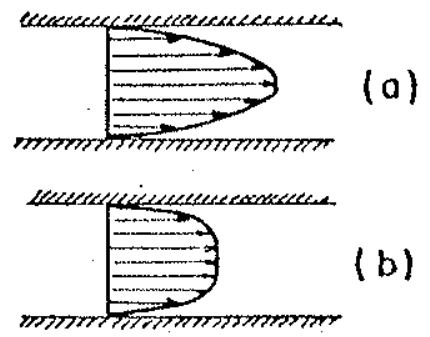

FIG.3.3-Distribuição de velocidades num tubo, laminar (a) e turbulento (b). (Schlichting, 1960)

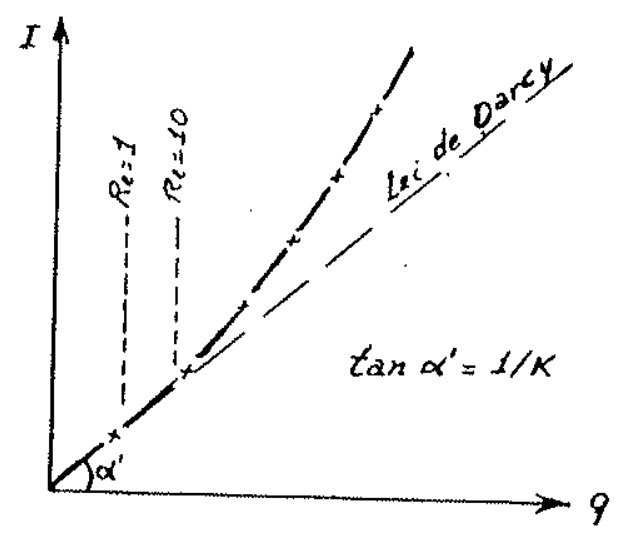

FIG.3.4- Iimite de validade da Lei de Darcy (BRAESTER, 1977) 
De un modo geral, o produto resultante da deformação, que maior interesse representa para a hidrogeologia, é decorrente da runtura, sendo denominado de fratura, tambem conhecida com as ter minologias de fissura, fenda, junta e diäclase. Esses termos, a pesar de serem distinguidos entre si por alguns autores, sobretu do no que diz respeito a amplitude (extensão e abertura), não são, a rigor, mais do que sinônimos, significando uma descontinuidade no maciço rochoso, procovada por uma ruptura, sem movimentos dos blocos quebrados.

A deformação ruptural em que ocorre movimento de um ou dois dos blocos quebrados, denomina-se fatha ou paraclase.

Dentre as vārias classificações estabelecidas para distin guir as fraturas, podem ser citadas as de FARRAN \& THENOZ com base na abertura, de TALOBRE com base no comprimento e a de DERRE basea da na frequência de espaçamento (in QUADROS,E.F.de,1977), conforme mostra. o Quadro $n^{\circ} 3.1$.

0 estudo da fissura sob o ponto de vista hidrogeológico compreende uma sërie de escalas, a saber:

a) as características hidräulicas da própria fissura, con siderada individualmente, ou seja, a fissura elementar;

b) o relacionamento dessa fissura com as demais existen tes no maciço rochoso, isto é, o meio fissurado;

c) o posicionamento e caracteristicas do meio fissurado em função da exploração das águas nele contidas, inclu sive as relações com as äguas superficiais subrejacen tes; ou, em outras palavras, as condiçōes de exploração do aquifero fissura 1.

\subsubsection{A FISSURA ELEMENTAR}

\section{3 .2 .1$. Elementos constituintes}

A anälise de uma fissura (ou fratura) isolada dos blocos constituintes do maciço rochoso, deve levar em consideração os se guintes elementos:
a) abertura
b) rugosidade das paredes 
QUADRO 3.1-Classificação das Descontinuidades, segundo FARRAN E THENOZ(1965) TALOBRE(1967)e DEERE(1968) contido em QUADROS(197.7)

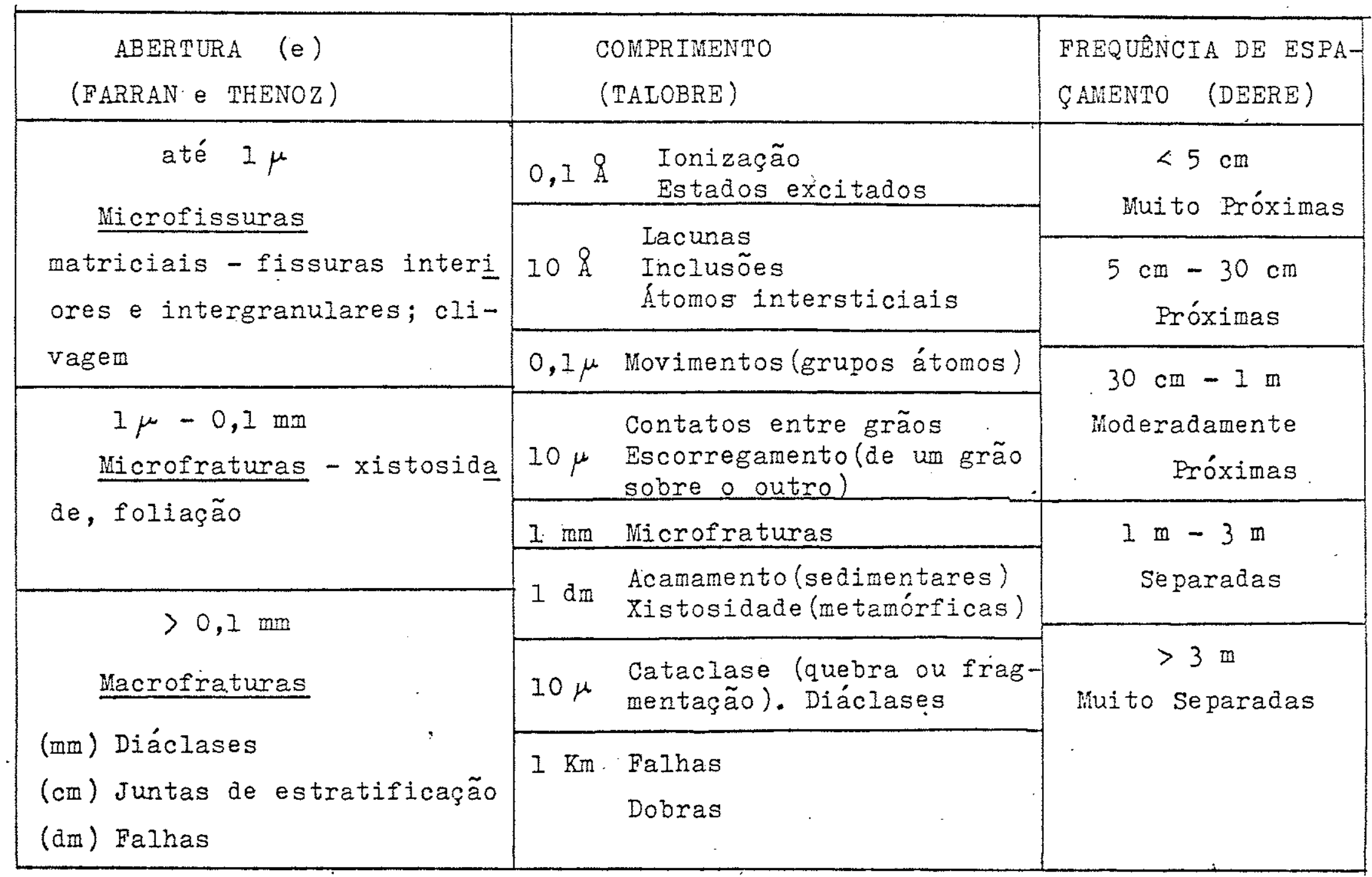




\section{a) abertura}

Abertura de uma fissura è definida como a medida de sepa ração entre as paredes rochosas ao longo do plano de quebramento.

Esse parâmetro ê de fundamental importância para a proble mätica de infiltração e armazenamento de ảgua e vai depender de dois fatores: tensões atuantes e tipo de rocha (em função das ca racteristicas fisicas dos minerais e da sua textura).

No que se refere às tensões atuantes, as deformações so fridas podem variar em função do tipo de esforço tensional aplica do (tracional ou compressivo), da diferença entre os esforços mä ximo e mínimo e por fim, das direções em que atuam no espaço, as três tensões $\left(\sigma_{1}, \sigma_{2}\right.$ e $\left.\sigma_{3}\right)$.

Quanto ao tipo de rocha, em função das caracteristicas fí sicas e texturais dos seus minerais, devem ser levados em conta a resistência ao cisalhamento $\left(S_{S}\right)$ e o môdulo de elasticidade(E). Os minerais granulares e isentos de clivagem, possuem maior $s_{s} e$ mais elevado $\mathrm{E}$, que os minerais placosos, ficando os minerais gra nulares com clivagem, em plano intermediärio. Nessas circunstânc as, as rochas que possuem predominância desses minerais mais resis tentes, ou aqueles de maior grau de metamorfismo, resistem mais à rutura por cisalhamento, alëm de possuirem menor frequência de fra turas, pois a energia de deformação acumulada na rocha, que é a responsävel pela sua ruptura, é inversamente proporcional ao mödulo E. En contra-partida, as fraturas originadas por tração nessas ro chas são mais abertas, pois as tensões tracionais geradas pelo es forço compressivo, são diretamente proporcionais ao mödulo E.Isso explica por que as rochas como o gnaisse e o migmatito, apresentam menor frequência de fraturas, porëm estas são mais abertas, ao con trārio dos filitos e ardósias que possuem maior frequência de fis suramento, porém as fissuras são mais fechadas.

A textura influi de värios modos: as rochas de textura granular grosseira são menos resistentes que as de textura granu lar fina, em virtude da predominância nas primeiras, dos planos de fraqueza representados pelas superficies de clivagem dos minerais (como o feldspato); por essa razão os pegmatitos e granitos porfi roblasticos (microgranitos) são mais quebradiços do que os grani tos de granulação fina. Do mesmo modo, as rochas de textura granu lar são mais resistentes do que as de textura lepidoblástica. 
b) rugosidade das paredes (k)

Rugosidade é definida como a distância entre duas linhas paralelas à linha média e que tangenciam a saliência mais pronun ciada e a reentrância mais profunda. Nas fraturas onduladas ru gosas, distingue-se a macrormgosidade e a microrrugosidade.Teorica monte, sabe-se que a macrormgosidade $(K)$ refere-se a distância en tre duas posições da parede de uma fratura, que sofreu uma varia ção de direção, enquanto a microrrugosidade (k) corresponde a dis tância entre a maior saliência e a maior reentrência de uma pare de de fratura. Ambas as distâncias são medidas perpendicularmente ao plano médio da fratura.

Rugosidade relativa é a relação entre a rugosidade absolu ta das paredes (k) e o diâmetro hidräulico (DH), sendo representa da pelo símbolo $\varepsilon$. O grau de rugosidade depende da origem da fra tura e ainda da granulometria, mineralogia e alteração das pareés rochosas nos planos de fratura. Sua influência na condutividade hidräulica é muito grande, pois pode acarretar elevadas perdas de carga, quando a água em circulação tende a acompanhar o relevo da parede rochosa.

Segundo BARTON(1975), as fraturas se classificam quanto a rugosidade em: dentada, ondulada e plana e cada uma dessas classes se subdivide nas sub-classes rugosa, lisa e polida ou espelhada (ver Fig.3.5). As fraturas mais comumente analisadas na hidrogeo logia são a plana polida (rugosidade relativa $\mathrm{k} / \mathrm{DH}$ menor que 0,033 ) e a plana rugosa (com $\mathrm{k} / \mathrm{DH}$ maior do que 0,033 ).

\subsubsection{Preenchimento das fissuras}

As fissuras podem estar total ou parcialmente preenchidas por material autöctone ou alóctone. A origem desse material pode estar 1igada a:

a) fragmentos da própria rocha fraturada (material autöc tone), em geral nas fraturas de cisalhamento ou zonas de falha provocada por compressão

b) detritos de origem superficial, que penetram em meio aquoso, de elevada turbidez, decantando no interior das fraturas 


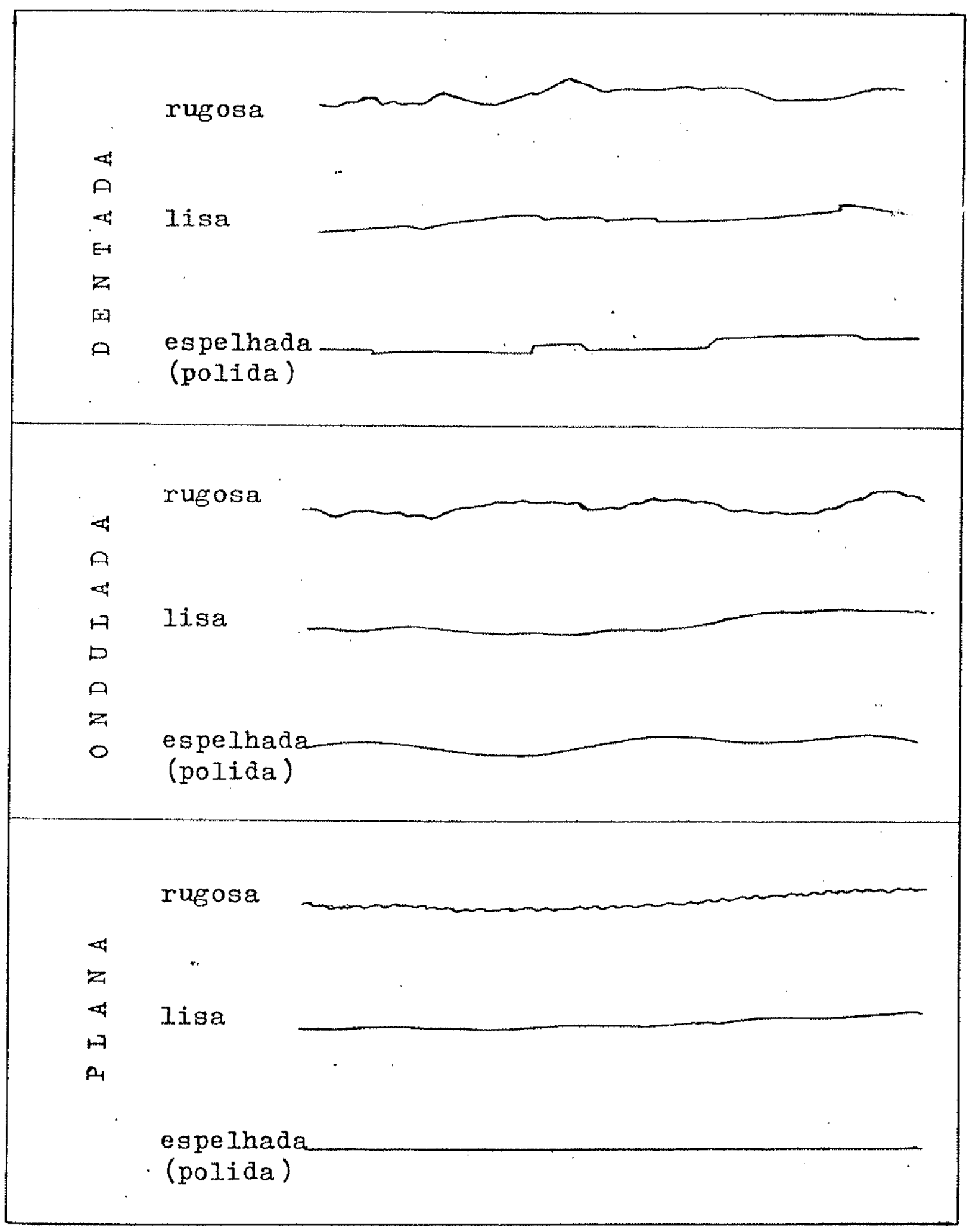

FIG.3.5-Perfís típicos de rugosidade, seg.BARTon(1975) inserido em QUADROS(1982) 
c) recristalização de sais que precipitaram em soluções, em função da evaporação do meio líquido que os trans portou; esse processo pode produzir uma cimentação $\overline{\mathrm{d} a}$ fratura ou mesmo uma eflorescência

d) ascenção de soluções hidrotermais mineralizantes, soli dificando em forma de cristais ou amorfa, quando a tem peratura cai sensivelmente próximo à superfície

Quando ocorre um processo de preenchimento, a permeabili dade da fratura irā depender quase inteiramente da permeabilidade do material penetrante; no caso a, pode ocorrer um aumento de per meabilidade da fratura, se o movimento que causou a fragmentação das paredes foi intenso a ponto de criar um sistema de vârias pe quenas fraturas conjugadas, interligadas com material semi-trit $\underline{u}$. rado a semi-pulverizado, da própria rocha; no caso todavia,de um movimento pouco intenso, com um ünico fraturamento, em geral as paredes vão ficar muito fechadas e os detritos muito pulverizados, diminuindo portanto a permeabilidade. No caso $\underline{b}$, a permeabilidade poderá ser boa se o material detrítico precipitado for de granulo metria psamitica, entretanto, se esse material for pelitico,a fra tura podera ficar praticamente impermeável. Os casos c e d, apesar da origem totalmente diversa (no primeiro o processo exö́geno e no segundo é endógeno), o resultado é praticamente o mesmo, isto é, uma completa impermeabilização da fratura, que se diz regelada.

\subsubsection{O METO FISSURADO}

\subsubsection{Características físicas}

Todo maciço rochoso constitui um meio fissurado de carac terísticas anisotrópica, heterogênea, descontínua e de extensão lateral finita; quando considerado em pequena área (grande esca 1a) o maciço rochoso pode não conter nenhuma fissura aberta, sendo designado por LOUIS(1974) de "matriz rochosa".

As descontinuidades do maciço rochoso são representadas pelas aberturas de vārias origens, como sejam: juntas de estrati ficação, de xistosidade, de clivagem, diäclases, paräclases, etć. 
Conquanto sob o ponto de vista da hidrogeotecnia, o estu do da ảgua nos meios contínuos seja considerado na hidräulica de solos e dos meios descontínuos na hidräulica de rochas, o maciço rochoso pode, eventualmente, ser considerado como um meio contí nuo, dependendo da "escala relativa" do fenomeno estudado e do mödulo de fissuramento.

A questão de escala relativa, acha-se esquematizada na Fi gura $\mathrm{n}^{\circ} 3.6$, onde $\vec{e}$ representado o mesmo problema hidráulico, para quatro meios diferentes, segundo LOUIS(1974). "Serä Iícito consi derar um meio fissurado como contínuo se a dimensão dos blocos e lementares for negligivel diante da dimensão do problema conside rado (caso 2 da Fig.3.6, ou seja, se for possivel enumerar, a tí tulo indicativo, mais de 10.000 fissuras numa seção plana qualquer. Por outro 1ado, se esse número for da ordem de 100 a 1.000 , a hipótese de descontinuidade do meio ẻ necessäria (caso 3) e no caso limite, se numa seção plana o nümero de fissuras for inferi or a 10 , cada fissura deve ser individualizada no modelo matema tico ou físico utilizado (caso 4). Os nümeros de fissuras que a cabam de ser mencionados, são muito subjetivos; de fato, a hipö tese conveniente de se adotar, deverá ser analisada cuidadosamen te para cada problema considerado" (LOUIS, 1974).

O maciço rochoso fissurado é constituido de blocos elementares que em conjunto constituem a matriz rochosa, separados por uma sërie de descontinuidades ou fissuras elementares, que em con junto recebem o nome de sistema de fissuras ou familia de fissuras ou ainda, rede de fissuras (se as mesmas se entrecortam).

\section{3 .3 .2 . Fatores que influem nas características hidrodinâmicas do meio fissurado}

A condutividade hidräulica (ou permeabilidade) e as condi ções de armazenamento d'ägua de um maciço rochoso fissurado, de pendem dos seguintes fatores (vide Fig. 3.7!):
a) amplitude das fissuras ( $l$ )
b) abertura das fissuras (e)
c) forma e rugosidade das paredes das fissuras
d) frequência ou espaçamento das fissuras (b) 

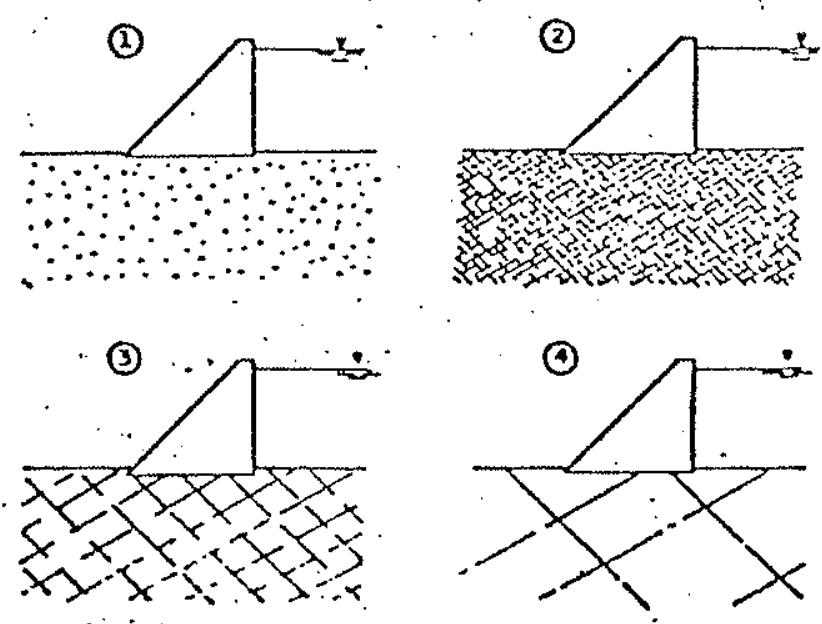

FIG. 3.6 - MEIO CONTÍNUO OU DESCONTÍNUO. (LOUIS, 1974)

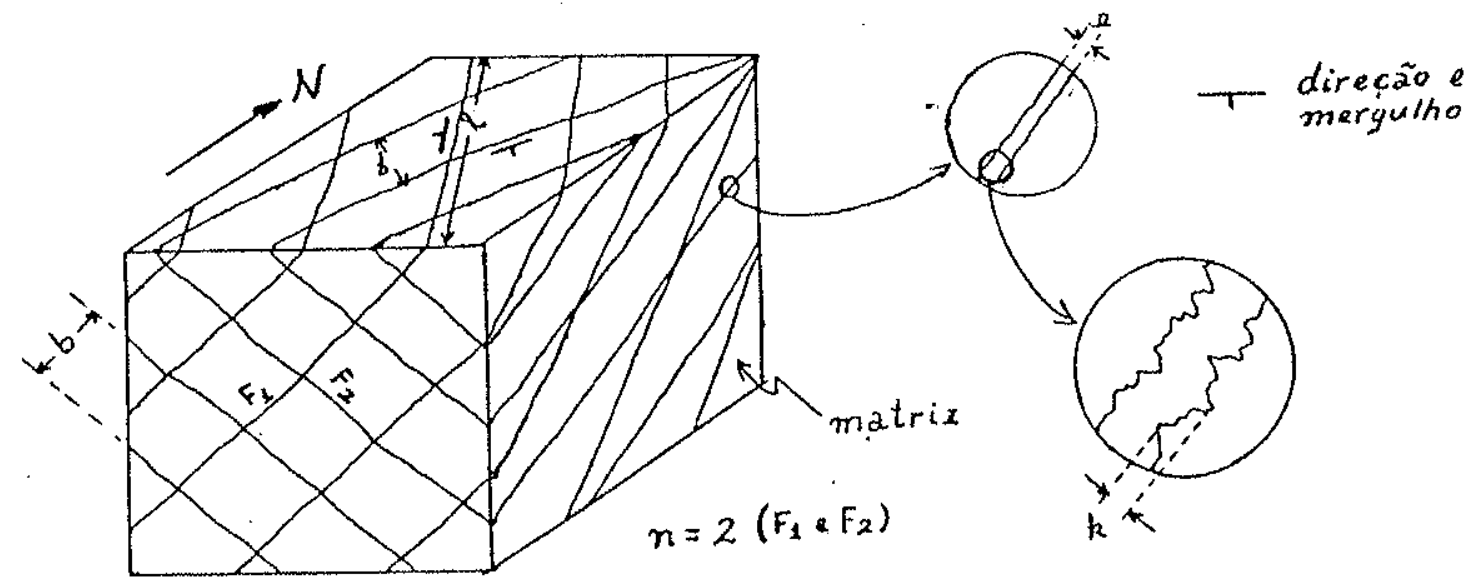

FIG.3.7 - Elementos do meio fissurado 
e) nümero de famílias ou sistemas de fissuras (n)

f) orientação e posição das fissuras (direção e mergulho)

g) porosidade e permeabilidade da matriz rochosa

h) propriedade do material que preenche as fissuras

i) distribuição da amplitude da fissura no sistema, que determina a heterogeneidade e anisotropia

\subsubsection{Características hidrodinâmicas do meio lissurado}

As caracteristicas hidrodinâmicas do sistema integrado do maciço rochoso, correspondem ao somatório das características das fissuras elementares, adicionados ainda às caracteristicas dos blocos elementares (quando permeáveis).

Assim, a velocidade de escoamento, è dada por:

$$
V=K \cdot I \quad \text { (regime laminar) }
$$

ou

$$
V=K^{\prime} \cdot I^{\alpha} \quad \text { (regime turbulento) }
$$

sendo:

K (laminar ou turbulento) - a condutividade hidráulica do maciço rochoso

$I^{\alpha}$ - gradiente hidráulico ativo (com $\alpha$, grau de não $1 \underline{i}$ nearidade, variando 0,5 em regime totalmente turbu lento a 1 no regime laminar)

A condutividade hidráulica direcional de um sistema de fissuras (em regime laminar ou turbulento) num maciço rochoso e dada por:

$$
k=\frac{e}{b} \cdot k_{f}+k_{m}
$$

em que :

K - condutividade hidräulica do maciço rochoso

e - abertura média das fissuras

b - espaçamento médio das fissuras

$k_{f}$ - condutividade hidräulica mëdia das fissuras

$\mathrm{k}_{\mathrm{m}}$ - permeabilidade da matriz rochosa

Frequentemente, na prätica, $k_{m} e ́$ desprezível diante do va lor de e.k $f$, a não ser quando não hä fissuras ou as mesmas es 
tão fechadas ou regeladas.

Constatamse na prätica, que os valores de condutividade hidräulica obtidos, são bem menores do que os valores teóricos obtidos a partir de espressões matemāticas (ver eq. ). Conside rando p.e. um maciço contendo uma fissura por metro (frequência b) e uma abertura média (e) de $1 \mathrm{~mm}$, teria uma condutividade hi dräulica de:

$$
K=\frac{0,001 \mathrm{~m}}{1 \mathrm{~m}} \times 1 \mathrm{~m} / \mathrm{s}=10^{-3} \mathrm{~m} / \mathrm{s}
$$

$\mathrm{Na}$ natureza não ocorre uma tal conduvidade hidráulica(em meios fissurados), pelo fato de as fissuras possuirem extensões Iimitadas e o conjunto ser um sistema de fissuras descontinuas. Em tal meio, o escoamento ê evidentemente anisotópico. "As fissu ras sem comunicação, provocam um curto-circuito do escoamento quando este ocorre na sua direção. As fissuras se comportam como possuindo potencial constante e a circulação da água se dä atra vés da matriz rochosa" (LOUIS,1974).

A condutividade hidräulica, na direção das fissuras, $\vec{e}$ dada por:

$$
K \approx k_{m}\left[d+\frac{1}{2}\left(\frac{d}{D-d}-\frac{d}{D}\right)\right]
$$

sendo:

D - distância entre os pontos médios das fissuras

d - extensão de uma fissura descontínua

b - espaçamento entre os sistemas de fissuras

d/D - grau de descontinuidade

b/D - frequência das fissuras (ver Fig. 3.8)

Observa-se que nesses sistemas de fissuras descontinuas, apenas o grau de descontinuidade e a frequência das fissuras, constituem "parâmetros hidrāulicos importantes". A permeabilida de matricial $k_{m}$ intervëm como um "coeficiente de proporcionalida de" nas condutividades hidräulicas dos diferentes sistemas de fissuras e sua influência não aparece a não ser nos cälculos de vazões.

Por outro lado, verifica-se que a abertura, a geometria da parede rochosa e a rugosidade das fissuras, "não representam nenhum papel". 
3.3.4. O AQÜTFERO FISSURAL

Um meio aquífero pode ser homogêneo ou heterogêneo, isótropo ou anisōtropo; $\vec{e}$ homogêneo quando as suas propriedades são constantes em qualquer lugar do mesmo e heterogêneo quando essas propriedades variam de um lugar a outro. Estritamente, todo meio poroso ou fissurado é um meio heterogêneo pela pröpria natureza, porém esse meio pode ser considerado macroscopicamente homogêneo se as propriedades consideradas em um certo volume do material ao redor de cada ponto considerado não variam de um lugar a outro (um conglomerado p.e. em escala de centimetro $\vec{e}$ um meio heterogê neo, porém em escala de metros, pode ser considerado homogêneo).

Um meio e hidraulicamente isotropo quando as suas proprie dades, principalmente a permeabilidade, não dependem de orienta ção, ou seja; que é igual em qualquer direção que se considere. Um meio homogêneo pode ser isótropo ou anisótropo. A isotropia tambëm admite un fator de escala.

o aquífero fissural, considerado em larga escala (de deze nas a centenas de metros) pode ser considerado como homogêneo, mas, em geral, e anisōtropo, pois apresenta direçōes preferenci ais de $f l u x o$, uma vez que as fissuras são na maioria dos casos, orientadas segundo determinadas direçôes.

BENEDINI et a11i(1972), mostra um esquema de representa ção bidimensional (segundo a horizontal e a vertical) de um aquí fero sedimentar estratificado (Fig..3.9-A) e de um aquífero fissu ral (Fig. 3.9-B), ambos exemplos de aquífero homogêneo anisötropo.

A permeabilidade segundo a horizontal (eixo dos $x$ ), segun do BENEDINI op.cit. serä dada por:

$$
\begin{aligned}
& K_{X}=\sum_{1}^{n} m \cdot \frac{K_{m} \cdot e_{m}}{e} \\
& \text { e, segundo a vertical (eixo dos y), por: } \\
& K_{y}=\frac{e}{\sum_{1}^{n} m \cdot \frac{e_{m}}{K_{m}}}
\end{aligned}
$$

sendo $e=\sum_{1}^{n} m \cdot e_{m}$, a espessura total do aquífero, consti 


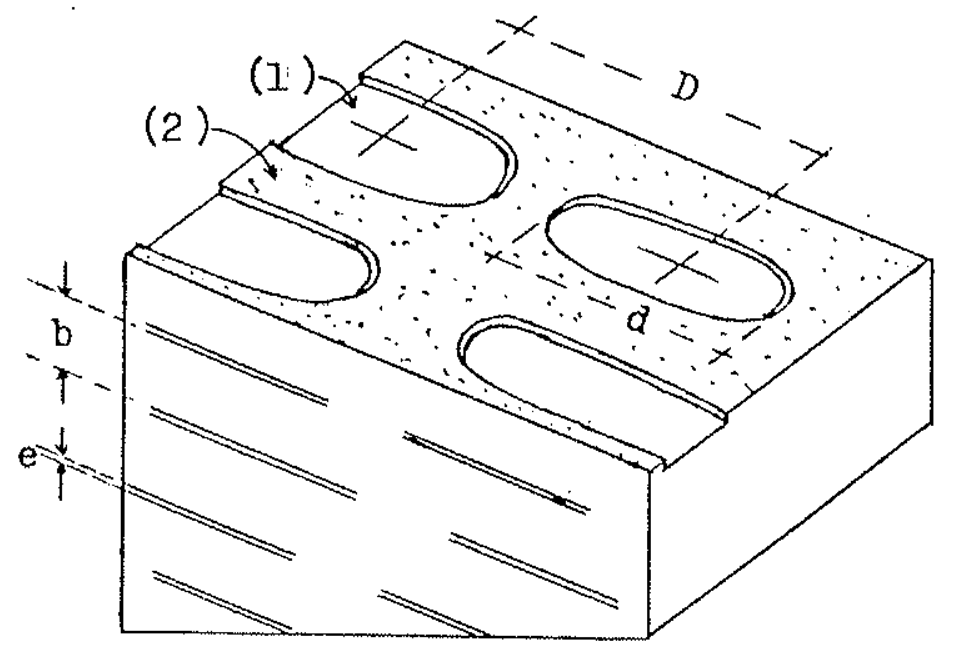
D - distância entre os pontos médios das fissuras
d - extensão de ura fissura descont.
e - abertura de una fissura.
b - espaçamento en- tre os planos de fissuras
(1) - fissura aberta
(2) - matriz rochosa

FIG. 3.8- Esquema mostrando a descontinuidade das fissu ras elementares no meio fissurado, segundo LoUts(1968)
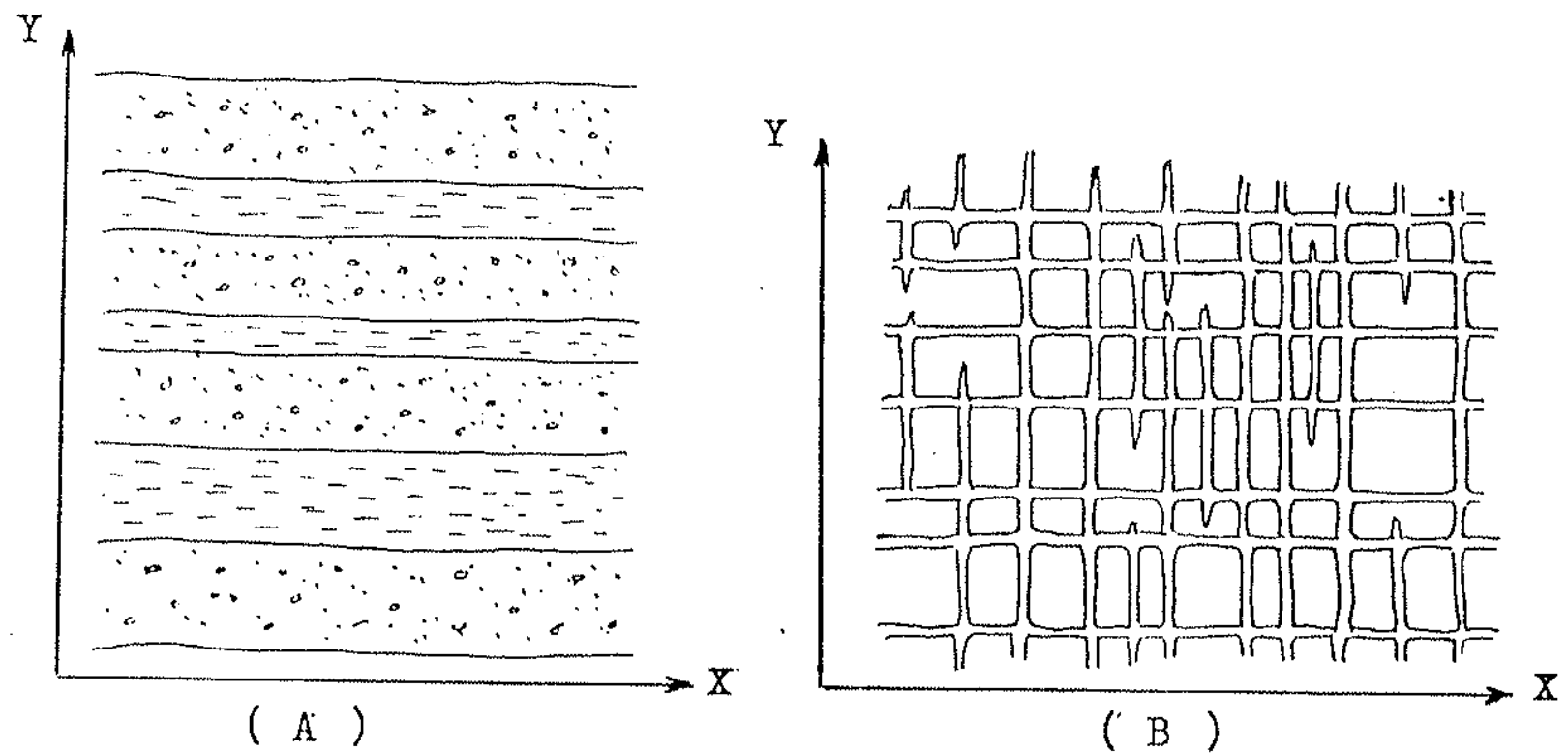

FIG.3.9-Representação bidimensional de um aquífero homogêneo anisótropo estratificado (A) e fissurado(B), $\mathbb{x}-$ gundo BENEDINI et alli (1972). 
tuido de $\underline{n}$ camadas ou fissuras elementares $(m=1 \ldots n)$ de espes sura $e_{m}$ (para cada camada) ou abertura $e_{m}$ (para cada fissura).

\subsection{FLUXO ATRAVES DO METO FISSURADO}

3.4.1. INTRODUÇÃO

As considerações teöricas sobre o escoamento dos fluidos em condutos de seção circular servem de base para o estudo dos fe nômenos de escoamento nas fraturas. O conceito de diâmetro hidráulico (Eq.5), normalmente empregado como meio de procurar uma equiva lência entre os resultados provenientes da anâlise do escoamento de fluidos em condutos de seção circular para aqueles de seção variada, é considerado adequado para o estudo do escoamento em fraturas.

o escoamento laminar de um fluido Newtoniano numa fratu ra 1 isa, pode ser explicado pela lei de Poiseuille. A geometra do problema assemelhamse ao caso de duas placas paralelas de abertu ra constante (Fig 3.19$)$.

Para fluxo turbulento, os resultados experimentais obti dos por Louis e Lomize são comparados com as fórmulas empíricas estabelecidas para condutos circulares através de um diagrama que relaciona o coeficiente de resistência $\lambda$, com o nümero de Reyno 1 ds (Fig. 3.10$)$.

3.4.2. FLUXO LAMINAR NUMA FRATURA PLANA, LISA, SEM PREENCHIMENTO

Admite-se que o escoamento seja retilíneo e paralelo, se a rugosidade relativa, $\mathrm{k} / \mathrm{DH}$ (relação entre a rugosidade absoluta e o diâmetro hidräulico) é menor ou igual a 0,033 (LOUIS, 1969).

A rugosidade relativa nas fraturas pode variar desde ze ro (fratura ideal, perfeitamente polida, com $k=0$ ) ate o valor de 0,5 (as duas paredes em contato); para este caso, $k=e$, e como 
$\mathrm{DI}=2 \mathrm{e}(\mathrm{liq} .5), \mathrm{vem}, \mathrm{k} / \mathrm{DH}=0,5$

Para fluxo laminar, a velocidade de fluxo é diretamente proporcional ao gradiente hidräulico. Tomando-se por base as equa çöes de fluxo estabelecidas para o escoamento de um fluido incom pressivel entre duas placas paralelas de abertura e, tem-se:

$$
V=k_{f} \cdot I_{f}
$$

Segundo LOUIS (1969):

$$
k_{f}=C \cdot e^{2}
$$

sendo:

$$
C=\frac{g}{12 \gamma}=\frac{g \cdot \gamma}{12 \mu}
$$

donde: $\quad k_{f}=\frac{e^{2}}{12}$

Essa expressão que relaciona a condutividade hidráulica de uma fratura com o quadrado da sua abertura, foi encontrada por BRAESTER(1977), atravẻs da comparação entre a equação de Hele-Shaw e a equação de Darcy, levando em conta ainda a equação da conser vação da massa.

Nos exemplos citados por BRAESTER (op cit), transcritos resumidamente a seguir, pode-se visualizar melhor a grande influ

\begin{tabular}{|c|c|c|c|}
\hline \multirow{2}{*}{$\begin{array}{l}\text { ABERTURA (e) } \\
\mathrm{em} \mathrm{mm}\end{array}$} & PERMEABILIDADE (k) & \multicolumn{2}{|c|}{$\begin{array}{l}\text { CONDUT IV IDADE } \\
\text { HIDRÄUL I CA }(\mathrm{K})\end{array}$} \\
\hline & em darcy & em & $\mathrm{m} / \mathrm{s}$ \\
\hline 0,001 & $\approx 10^{-1}$ & & $10^{-6}$ \\
\hline 0,1 & $\approx 10^{3}$ & $\approx$ & $10^{-2}$ \\
\hline 1 & $\approx 10^{5}$ & $\approx$ & 1 \\
\hline
\end{tabular}
ência que exerce na condutividade hidräulica, a abertura de uma fratura:

Conforme jâ visto, a abertura da fratura depende do môdu 10 de elasticidade (E) da rocha e do estado de tensões atuantes na crosta e assim, varia com o tipo de rocha e a profundidade em que se desenvolveu o processo. 
LOUIS(1969), esquematizou os regimes de escoamento numa fratura atravês de um diagrama que permite visualizar três domí nios, cujos limites determinam a validade das leis de escoamento.

Na Fig.3.11, pode-se distinguir:

a) regime hidraulicamente 1 iso 1 e 2

$$
\lambda=f(\operatorname{Re})
$$

b) regime intermediärio 3

$$
\lambda=f(\operatorname{Re}, \mathrm{k} / \mathrm{DH})
$$

c) regime completamente turbulento ou completamente ru go so 4

$\lambda=\mathrm{f}(\mathrm{k} / \mathrm{DH})$

Os limites definidos através do numero de Reynolds entre os domínios 2 e 3 e domínios 3 e 4 , são funções decrescentes da rugosidade relativa. Esses limites determinam os domínios de vali da das leis de escoamento.

No domínio 1 , para Re aproximadamente igual ou inferior a 2.300 , todos os pontos experimentais obtidos por Louis, estão si tuados numa mesma 1 inha reta e são independentes do valor da rugo sidade relativa (Fig. .10$)$, pode-se concluir que, neste domínio, a rugosidade não desempenha qualquer efeito na perda de carga para fluxo laminar e que a perda de carga é função unicamente das pro priedades do fluido. Se k/DH $\leqslant 0,033$, é aplicável a lei de Poiseu i.1. (1inha 1, Fig. 3.10). Se k/DH > 0,033, a influência da rugosida de pode ser considerada por meio de um fator que depende do valor da rugosidade relativa da fratura. Para este caso, a lei de escoa mento proposta estä mostrada a seguir (LOUIS, 1969):

$$
\lambda=\frac{96}{\operatorname{Re}}\left[1+8,8(\mathrm{k} / \mathrm{DH})^{1,5}\right]
$$

Para Re acima de 2.300 (domínio 2, Fig.3..11), é aplicävel a lei de Blasius (1inha 3, Fig.3.10). Este regime é conhecido como hidraulicamente liso, no qual as perdas de carga são influencia das, tal como no regime laminar, apenas pelas propriedades físi 


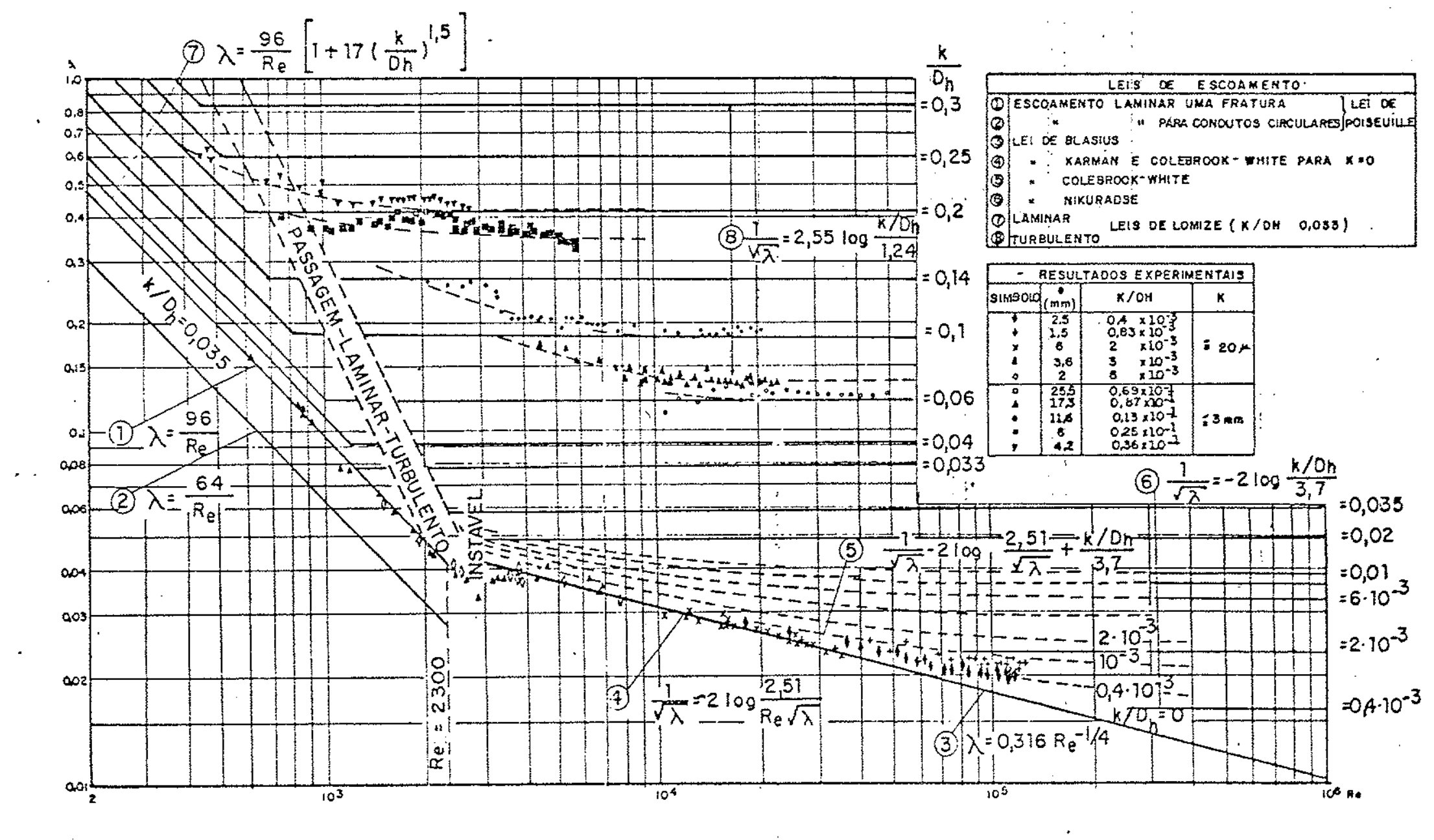

FIG.3.10 - Leis de escoamento numa fratura e resultados experimentais de Louis (1969) 
cas do flüido. As perdas de carga que se estabelecem durante o escoamento são apenas por atrito viscoso do fluido nas paredes da fratura. Portanto,

$$
\lambda=0,316 \mathrm{Re}^{-1 / 4}
$$

Para este domínio é aplicävel tambëm a lei de Karman (1inha 4, Fig.3.10):

$$
\frac{1}{\sqrt{x}}=-2 \log \frac{2,51}{\operatorname{Re} \sqrt{\lambda}}
$$

o domínio 3 constitui uma região de transição entre os regimes hidraulicamente 1 iso e completamente rugoso, a qual de pende de $\mathrm{Re}$ e $\mathrm{k} / \mathrm{DH}$. Considera-se aplicāvel neste domínio a equa ção de Colebrook e White (linha 5, Fig.3.10).

$$
\frac{1}{\sqrt{\lambda}}=2 \log \left(\frac{2,51}{\operatorname{Re} \sqrt{\lambda}}+\frac{k / D H}{3,7}\right)
$$

$\mathrm{Na}$ equação 30 , quando $k$ tende para zero e o valor de $\mathrm{k} / \mathrm{DH}$ é muito pequeno, o segundo termo da equação pode ser despre zado e a lei de Colebrook-White identifica-se com a lei de Karman Da mesma forma, se Re for muito grande, o primeiro termo dentro do parênteses na equação 3 pode ser desprezado e esta se identi fica com a equação proposta por Nikuradse para regime completamen te rugoso (Iinha $6, \mathrm{Fig} .3 .10$ ).

Para valores elevados de $\operatorname{Re} e \mathrm{k} / \mathrm{DH}, \lambda$ depende unicamente da rugosidade relativa e independe de Re. o regime é definido co mo regime completamente rugoso, uma vez que o coeficiente de a trito depende principalmente da altura das asperezas e independe das propriedades do fluido. Considera-se aplicável para este do mínio a lei de Nikuradse para valores de $\mathrm{k} / \mathrm{DH} \leqslant 0,033$ (LOUIS,1969).

$$
\frac{1}{\sqrt{\lambda}}=-2 \log \frac{\mathrm{k} / \mathrm{DH}}{3,7}
$$

Para $k / D H>0,033$ Lomize propõe que seja aplicada a se guinte equação para o fluxo em fraturas:

$$
\frac{1}{\sqrt{\lambda}}=-2,55 \log \frac{\mathrm{k} / \mathrm{DH}}{1,24}
$$




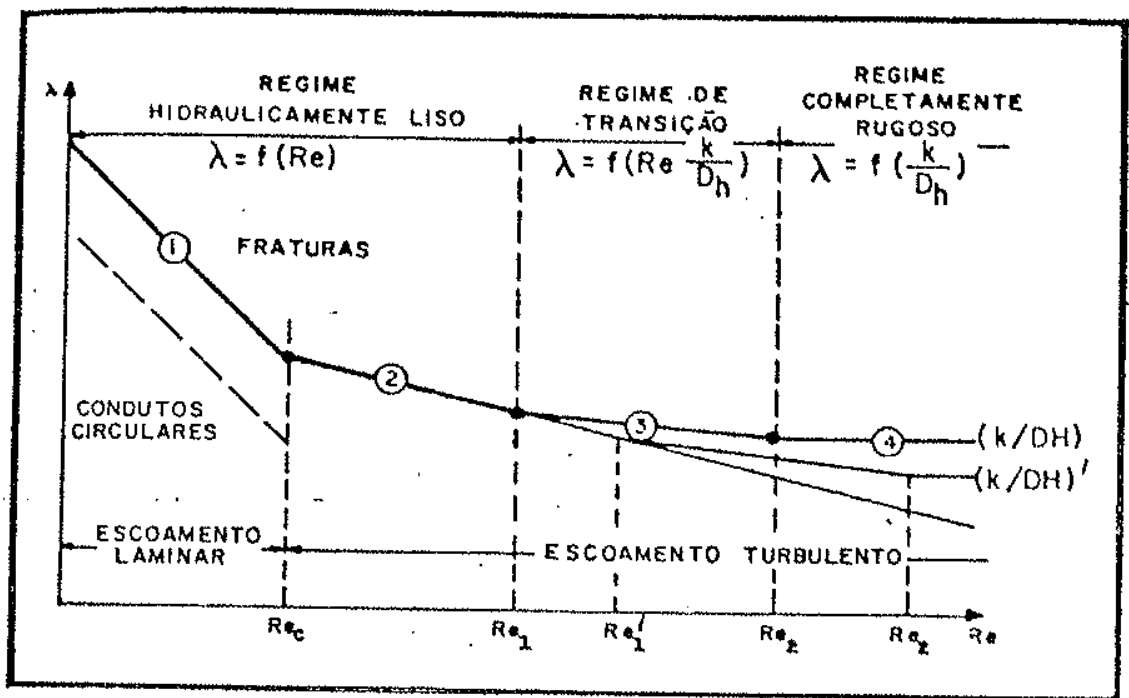

FrG.3.11- Esquematização das leis de escoamento e dos diferentes regimes de escoamento(Louis, 1969) 
P $\triangle$ R T E 2:

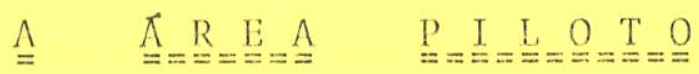


CAP TTULO NO 4

CARACTEERIZACCAO FIISIOGRAITCA DA AREA 
4.1. INTRODUCAO

o estudo das características fisiogräficas de uma dada região constitui sempre um valioso elemento complementar nos trabalhos e pesquisas envolvendo recursos hídricos, pedológicos agro-pecuärios, ou outras äreas de recursos naturais.

Alēm dessa importância genërica, os elementos da fisiografia, como o clima, relevo, hidrografia, vegetação e solos (a geologia serâ tratada a parte) desempenham um papel fundamental no estudo hidrogeológico do aquífero fissural, uma vez que, como foi visto no Cap.2, constituem esses elementos, os fatores exó-. genos que exercem influência na quantidade e qualidade das àguas subterrâneas.

Assim, serä tratado individualmente cada elemento da fisiografia, com uma anâlise das características regionais e suas influências no aquiffero fissural.

4.2. CLIMA

4.2.1. ELEMENTOS DO CLIMA

Os mais importantes elementos do clima são a pluviosidade (ou precipitação) e a temperatura , sendo ainda utilizados para a caracterização climâtica regional os seguintes elementos:

- circulação atmosfërica (ventos)

- umidade relativa

- evapotranspiração potencial

- rea1.

O balanço hídrico, elaborado pelo mëtodo de Thornthwait leva em conta, sobretudo, a precipitação e a evapotranspiração potencial; o zoneamento ärido de De Martonne, tem por base a pre cipitação e a temperatura; as diversas classificaçöes climäticas como a de Koppen, Gaussen e Nimer, baseiam-se principalmente na 
precipitação e na temperatura. O Projeto RADAMBRASIL adota uma classificação climätica mais completa, que leva em consideração - indice de umidade (segundo Thornthwait), a precipitação total anual, o excedente hídrico anual, o nümero de meses com excedente hidrico, a deficiência hídrica anual, o nümero de meses com deficiência hîdrica e, secundariamente, a temperatura mëdia anua 1 .

\subsubsection{CIRCULAÇAO ATMOSFERTCA E A GENESE DAS CHUVAS}

Os sistemas de circulação atmosfêrica, que influenciam as condições de tempo na ärea são, segundo NIMER (1977): sistema de correntes perturbadas do sul (FP); sistema de correntes perturbadas do norte (CIT); sistema de correntes perturbadas de leste (WE) e sistema de correntes perturbadas de oeste (IT), os dois ültimos considerados secundärios. Segundo REIS (1976)os sis temas são apenas três, a saber: massa Equatorial atlântica (mEa a Convergência Intertropical (CIT) e a Frente Polar Atlântica( FPA).Ver Fig.4.1.

A ärea em estudo permanece o ano inteiro sob a ação do anti-ciclone do Atlântico Sul, reponsâvel pelo bom tempo no hemisfêrio meridional, $E$ o ar dos Alíseos de SE que predomina em toda a ärea durante o ano. A massa de ar transportada pelos Aliseos(massa Equatorial Atlântica) compõe-se de duas correntes: a inferior, mais ưmida, ë refrescada por descargas do ar polar, enquanto que a superior se apresenta quente e seca, em razão de uma forte camada de inversão tërmica que as separa, impedindo a sua mistura. Quando os ventos atingem a plataforma litorânea da parte oriental que lhes antepõe ao fluxo dominante, a inversão tërmica se desfaz gradualmente, gerando uma instabilidade condicional da massa do ar, permitindo a ascensão da camada superfici a1 dos Alíseos e, consequentemente, a condensação e a precipitação. Essas chuvas contudo, não atingem o interior, detendo-se na vertente 1.este da Chapada da Borborema, o que reforça ainda mais o fenômeno.

A zona seca da ärea $\hat{e}$ uma resultante da predominância do ar estävel trazido pelos Alíseos. Essa condição pode perdurar, , 


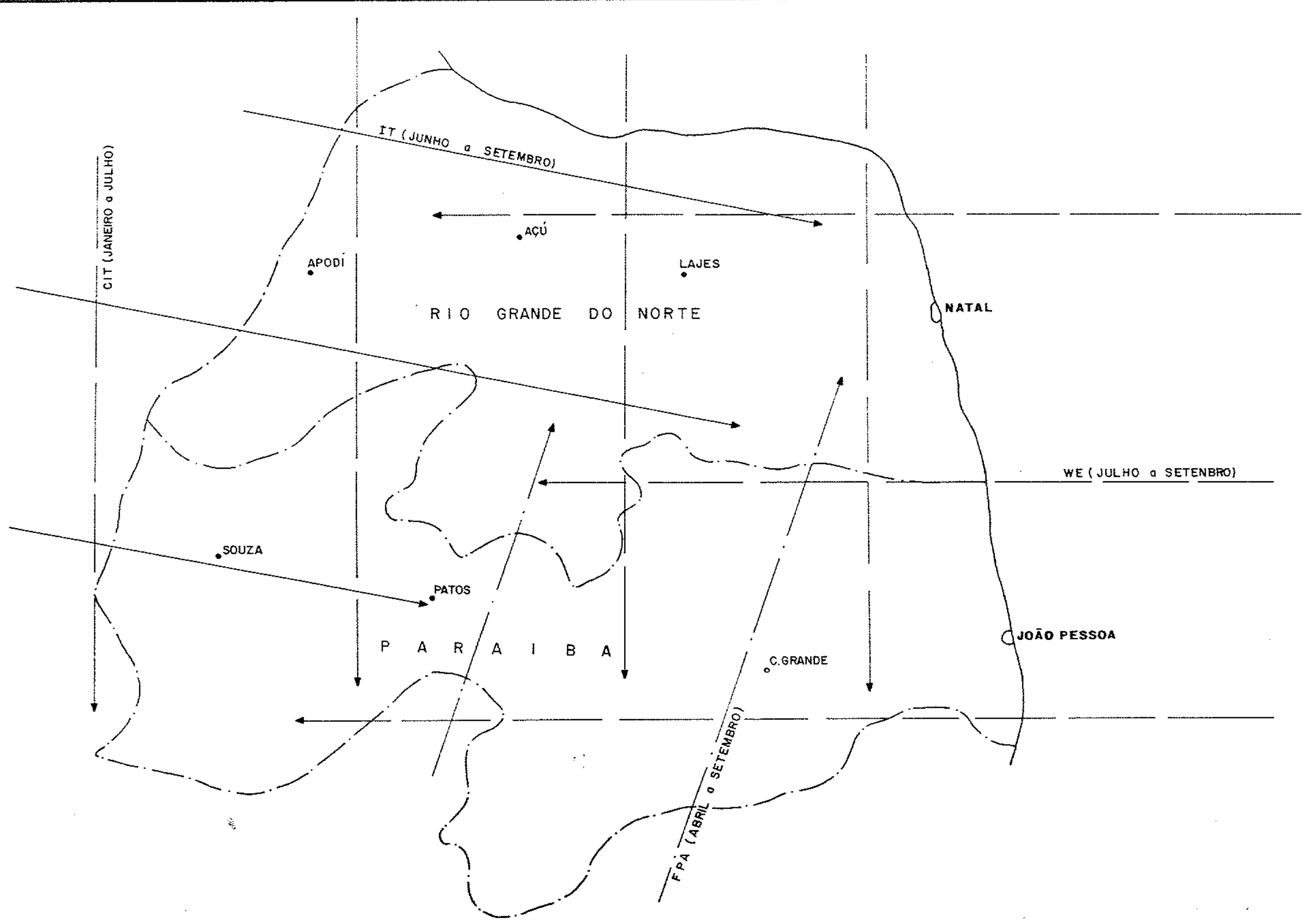

FIG. 4.1 - SISTEMA DE CIRCULAÇĀO ATMOSFÉRICA (SEG REIS E NIMER, MODIFICADO P/ RADAMBRASIL) 
dando origem às calamitosas secas que, com relativa frequência, se abatem na ärea. O mais comum, porëm, ë que as penetraçöes das correntes perturbadas de oeste-noroeste, a oeste da ärea alia da às ondulações da Convergência Intertropical, a noroeste, determinem a estação chuvosa em grande parte da ârea, na sequência veräo-outono. No resto, hä que se salientar o litoral, de clima ümido, onde a estação chuvosa de outono-inverno estä sob a influência das descargas de ar polar da Frente polar do Atlântico, muito frequentes e enérgicas naquela parte do ano.

\subsubsection{PLUVIOMETRIA}

A distribuição espacial da pluviometria $\vec{e}$ mostrada no Cartograma da Fig. 4.2. , revelando uma grande heterogeneidade ao longo da ärea, desde $1.800 \mathrm{~mm} /$ ano atê $300 \mathrm{~mm} / \mathrm{ano}$. A pluviometria mais acentuada corresponde à região 1itorânea oriental, secundada pelas serras e brejos.

As serras são äreas de influência orogräfica, onde a in terceptação da umidade se faz de maneira marcante. Durante o período chuvoso, sistemas pluviais da Convergência Intertropical ai se intensificam. Ao longo do período seco, a ocorrência da precipitação oculta (orvalho e nevoeiro) possibilita maior conservaçäo da umidade no solo, evitando parte da evapotranspiração potencial. Essas ârea são representadas pela Serra do Teixeira, Serra dos Cariris Novos, Serra do Camarä, Serra João do Vale, Ser ra de Sta. Luzia, dentre outras de menor porte, onde as precipitações variam de 800 a $1.000 \mathrm{~mm} / \mathrm{ano}$.

os brejos assemelham-se às áreas serranas, no que diz: respeito à intercepção da umidade, ocorrendo maior precipitação devido à perturbação orogräfica dos fluxos estâveis dos Alíseos. Entretanto, diferenciam-se das serras pelo menor porte que apresentam, interceptando, assim, menor quantidade de umidade. Podem ser citados, dentre outros, o brejo de Martins - RN (1.086mm) e Cuité - PB (91.3mm).

Quanto a distribuição da pluviometria no tempo, ë muito variảve1 em função da localização (coordenadas da longitude e latitude), da altitude e outras condições locais como ventos, u- 


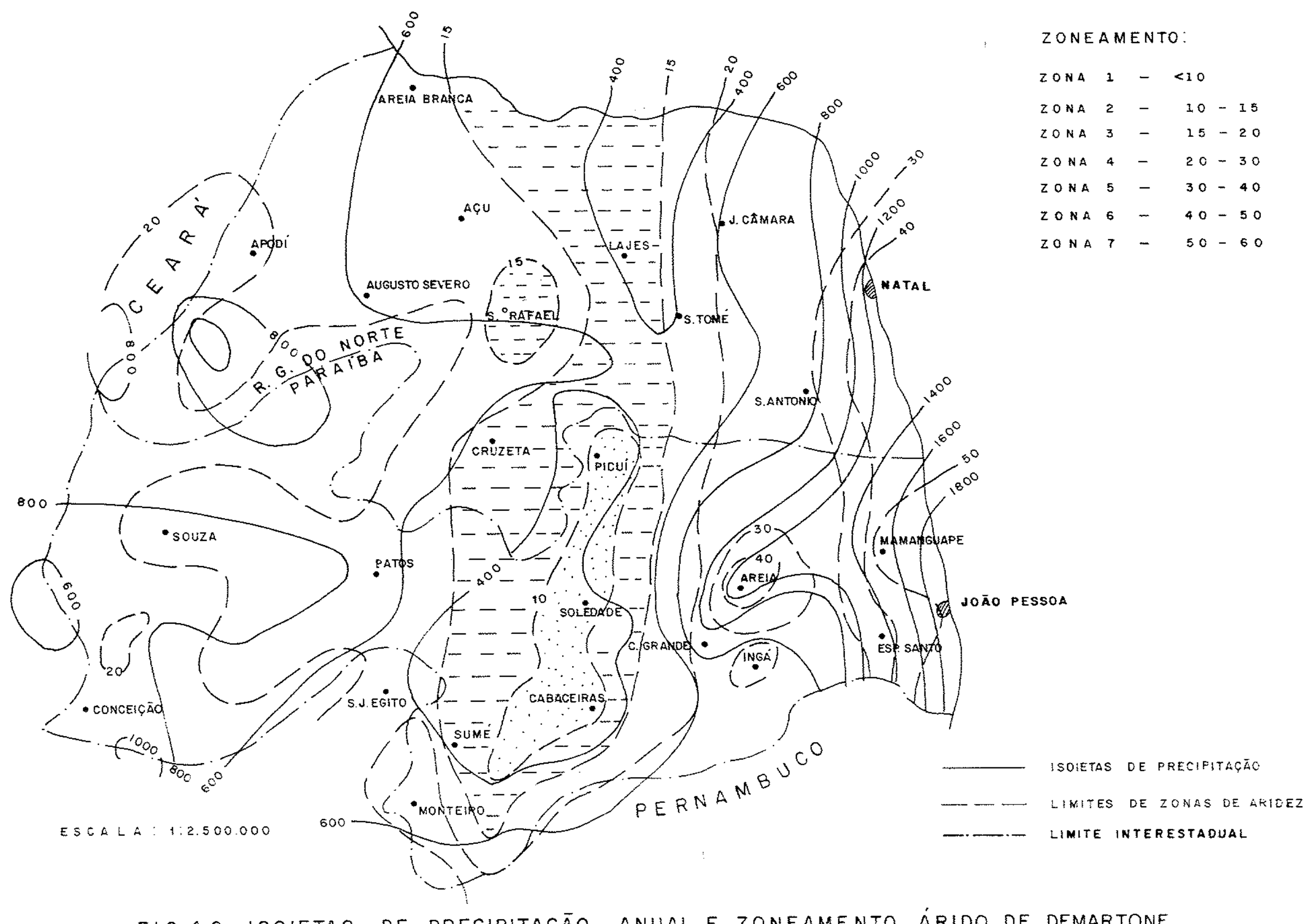

FIG.4.2 ISOIETAS DE PRECIPITAÇĀO ANUAL E ZONEAMENTO ÁRIDO DE DEMARTONE 
midade, evapotranspiração, etc. Nos cartogramas da Fig.4.3 ( A a D) verifica-se que enquanto na região mais oxiental (a leste do meridiano $36^{\circ} 00^{\prime}$ ) as precipitaçōes ocorrem no inverno na região ocidental da ärea as precipitações são mais intensas no outono. O verão marca o inĩcio das precipitações no sertão e 1itom ral enquanto na primavera praticamente inexiste precipitação em ambas as regiões.

No Quadro 4.1 pode-se observar os valores mêdios de preci pitação com respectivos indices de dispersão, em 13 postos pluvi omëtricos distribuîdos na ärea (in ALBUQUERQUE, 1971).

\subsubsection{TEMPERATURA}

A cartograma de isotermas (Fig.4.4), demonstra que toda a ârea estä submetida a alta temperatura mêdia anual, bem como a fraca oscilação têrmica.

No Iitoral, as mëdias variam de $24^{\circ} \mathrm{C}$ a $26^{\circ} \mathrm{C}$, em função da ação dos Alîseos; nos setores do litoral setentrional e das äreas norte e noroeste elas atingem os $28^{\circ} \mathrm{C}$. Constituem exceção os niveis mais elevados do planalto da Borborena, com temperaturas mëdias que variam em torno de $22^{\circ} \mathrm{C}$.

A curta"estação fria" ocorre nos meses de junho e jutho. Esses meses são os mais representativos do inverno austral, ëpoca em que o sol se encontra mais afastado do zênite, e em que, por conseguinte, é menor a radiação. Os demais meses possuem temperaturas mais elevadas, sobretudo outubro-novembro, no setor ocidental da ärea, e janeiro-fevereiro, no setor oriental. As altas temperaturas se acentuam progressivamente à medida que di minue!l as cotas de altitude e se penetra no interior. Nestas $\underline{a}$ reas deprimidas interiorizadas, muito pouco beneficiadas pela a ção dos alîseos, observam-se fortes quedas de temperatura por ra diação noturna, mais significativas no inverno. 
QUADRO 4.1 - VARIABILIDADE DAS CHUYAS ANUATS

\begin{tabular}{|c|c|c|c|c|c|c|}
\hline NOME DO POSTO & $\begin{array}{l}\text { NOMERO } \\
\text { DE ANOS } \\
\text { OBSER } \\
\text { VADOS }\end{array}$ & $\begin{array}{l}\text { MEDTA } \\
\text { DO PE } \\
\text { RIODO } \\
\text { OBSER } \\
\text { VADO } \\
\text {-P - } \\
\text { (mm) }\end{array}$ & $\begin{array}{c}\text { DESVTO } \\
\text { PADRAO } \\
(\mathrm{mm})\end{array}$ & $\begin{array}{c}\text { COEFICI } \\
\text { ENTE DE } \\
\text { VARIACCAO } \\
-C V- \\
\left(\frac{0}{0}\right)\end{array}$ & $\begin{array}{c}\text { MAXTMO } \\
\text { OBSER } \\
\text { VADO } \\
(\mathrm{mm})\end{array}$ & $\begin{array}{l}\text { MINIMO } \\
\text { OBSER } \\
\text { VADO } \\
\text { (mm) }\end{array}$ \\
\hline Martins & 49 & 1.045 & $4 \mathrm{I} 5$ & 40 & 1.910 & 153 \\
\hline Patu & 51 & 736 & 308 & 42 & 1.752 & 164 \\
\hline Serra Negra do Norte & 50 & 680 & 290 & 43 & 1.480 & 84 \\
\hline Jardim do Seridö & 54 & 651 & 250 & 46 & 1.166 & 103 \\
\hline Currais Novos & 48 & 430 & 219 & 51 & 899 & 73 \\
\hline picui & 51 & 352 & 168 & 48 & 855 & 102 \\
\hline Souza & 46 & 747 & 309 & 41 & 1.348 & 140 \\
\hline Cajazeiras & 49 & 860 & 30.0 & 35 & 1.618 & 284 \\
\hline Teixeira & 47 & 702 & 390 & 56 & 1.876 & 1.74 \\
\hline Patos & 50 & 751 & 381 & 51 & 1.912 & 165 \\
\hline Itaporanga & 49 & 826 & 358 & 43 & 1.858 & 224 \\
\hline Taperoä & 40 & 506 & 262 & 52 & 1.077 & 81 \\
\hline Princesa Isabel & 53 & 785 & 260 & 33 & 1.608 & 163 \\
\hline
\end{tabular}

Fonte: SUDENE (1971) 


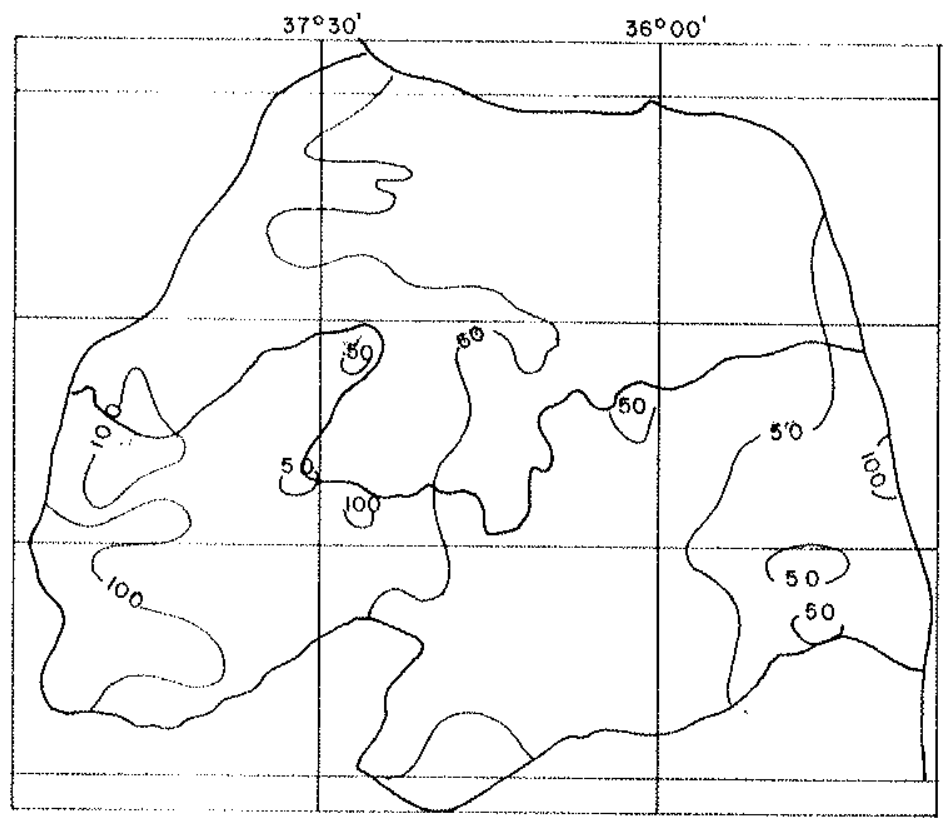

A- EM JANEIRO (VERÃO)

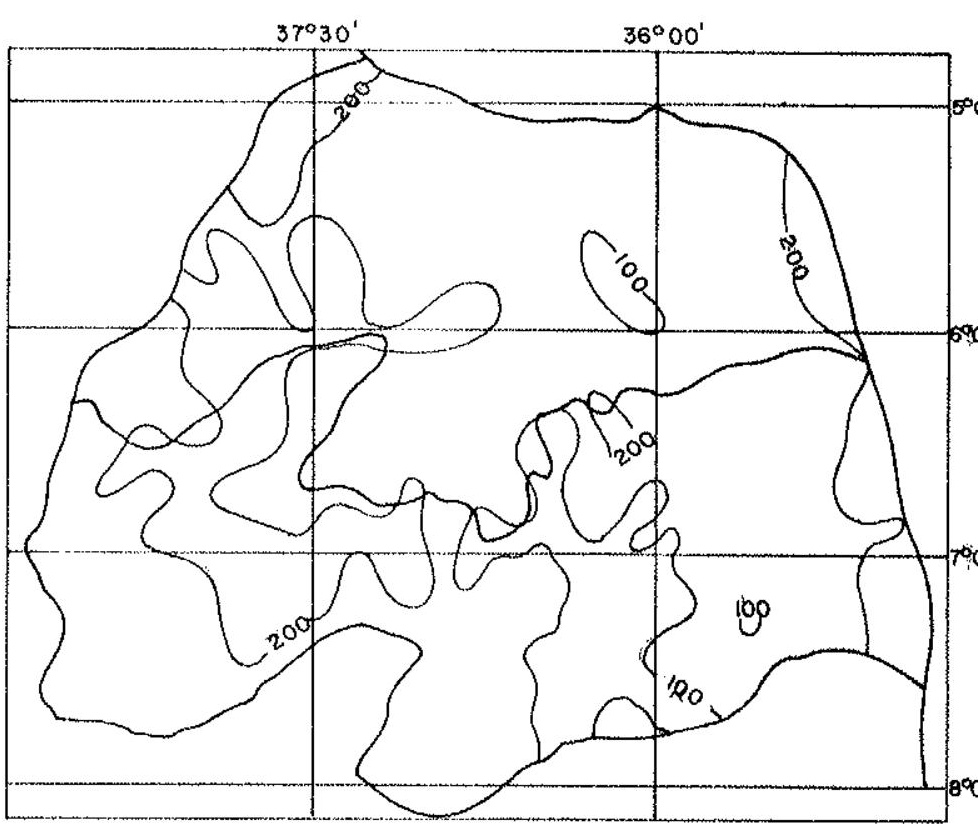

B - EM ABRIL (OUTONO)

LEGENDA:

$$
\text { - } 50-1 \text { SOIEATAS }(\mathrm{mm})
$$

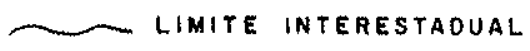

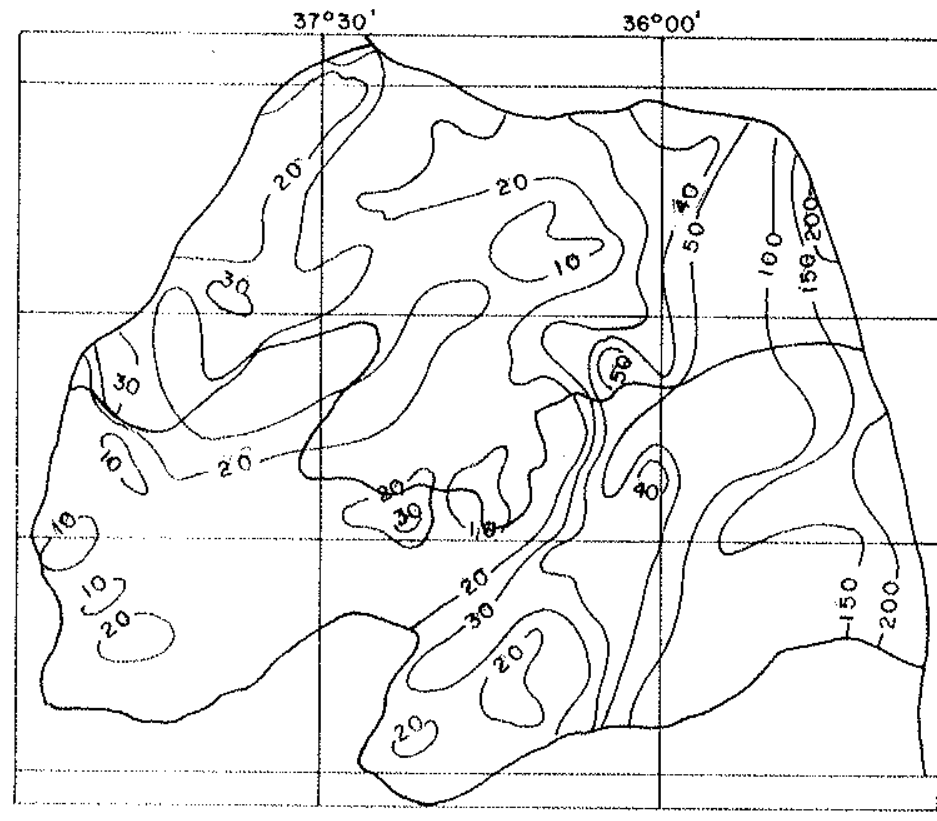

C-EM JULHO ( INVERNO)

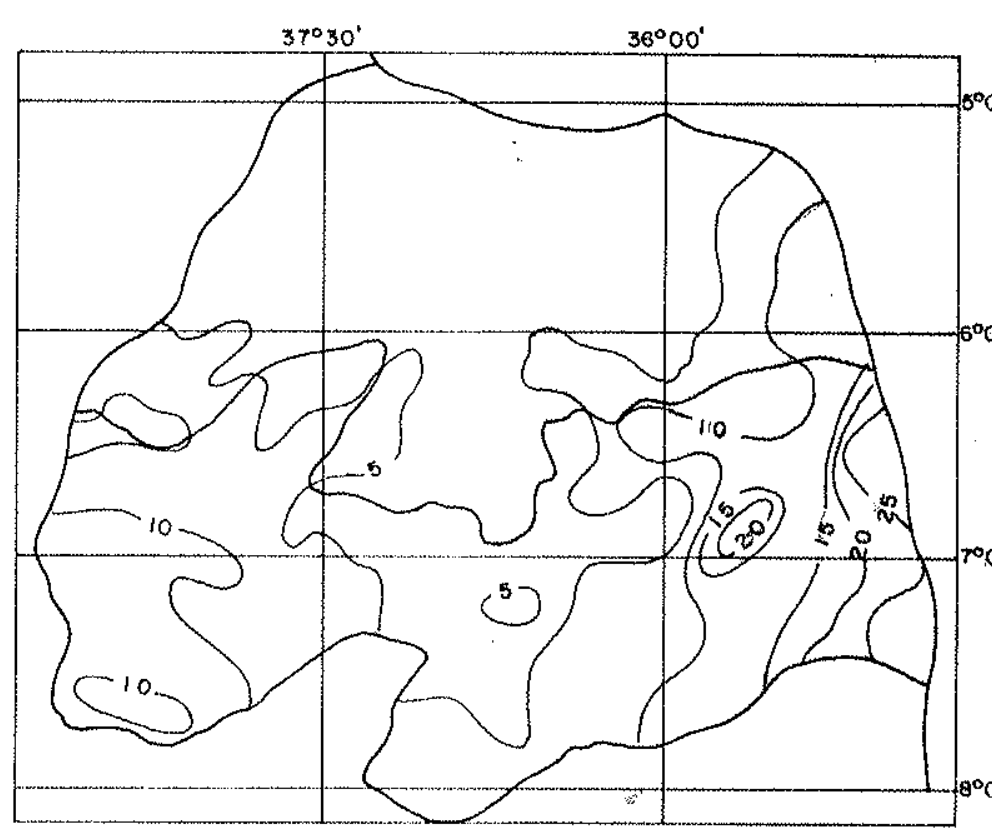

D - em outugro (Primavera)

FONTE: RADAMBRASIL - LEVANTAMENTO DE RECURSOS NATURAIS - VOL. 23 ESCALAPROX. T: 3.000 .000

FIG. 4.3 PLUVIOMETRIA MÉdIA MENSAL POR ESTAÇŌES DO ANO 
4.2.4. EVAPOTRANSPIRACAO POTENCIAL E REAL

A evapotranspiração potencial - EP - é um îndice utiliza do para indicar a necessidade de ägua por unidade de ärea, ou seja, a âgua teoricamente necessäria para manter a vegetação ver de durante todo o ano, sendo tambëm uma função direta da tempera tura.

Correlacionando-se o cartograma de evapotranspiração potencial anual ( Fig.4.5) com o cartograma de temperatura mëdia anual (Fig.4.4), percebe-se que os menores indices de EP aparecem onde se registram os menores indices tërmicos, como as äreas serranas do Teixeira e divisor hidrogräfico das bacias orientais e setentrionais. Por outro lado, toda a zona litorânea e aquelas situadas nas depressões interplanálticas e a sotavento dos maciços orogräficos apresentam os maiores indices de EP, associados aos mais elevados indices têrmicos.

A evapotranspiração rea1 - ER - corresponde à quantidade de água que, nas condições reais, se evapora do solo e trans pira das plantas. A cartograma da evapotrañspiração real. (Fig.

.6) mostra que os mais elevados valores da ER são encontrados no litoral oriental, diminuindo para o interior, à medida que di minuem os valores da precipitaçäo.

4.7.5. UMTDADE RELATIVA

Esse parâmetro apresenta uma grande diversificação da costa leste para o interior. Assim, na região litoral oriental e na vertente ocidental do Planalto da Borborema a umidade relativa varia entre 80 e $85 \%$, elevando-se nos meses de inverno para atê $90 \%$. Em direção ao interior, bem como na costa setentrional, onde $\vec{e}$ escassa a disponibilidade da âgua, o percentual de evaporação $\vec{e}$ reduzido, alcançando valores entre 60 e $65 \%$.

Uma forma de representação da umidade do ar ê através do Indice de Umidade, de Thornthwatt, definido pela expressão:

$$
\operatorname{Im}=\frac{100 \cdot \operatorname{Exc} \cdot 60 \cdot \operatorname{Def}}{\mathrm{EP}}
$$


em que Exc: representa o volume do excedente e Def o vo lume de deficiência da ägua no solo; no Balanço de Thornthwaite EP representa a evapotranspiração potencial. Segundo Thornthwaite não haverä seca se a deficiência hídrica do período seco não for alëm de $60 \%$ do excedente hîdrico anual.

Os valores positivos de Im correspondem aos clima ümi dos e os negativos, aos climas secos, em todas as suas nuanças. Portanto, a isolinha de valor igual a zero separa o clima subümido do clima subseco. (Ver Eig. 4.8).

\subsubsection{BALANÇO HIDRTCO}

O Balanço Hïdrico de Thornthwaite estabelece a integração entre a evapotranspiração potencial, precipitação e evapo transpiração real, utilizando-se das representaçöes do excedente hidrico e deficiencia hidrica. O excedente hídrico è a quantida de de ăgua precipitada que não è absorvida pelo solo e não ê eva potranspirada, incorporando-se à rede de drenagem superficial ou aos aquîferos subterrâneos. Deficiência hîdrica ê o saldo negati vo que ocorre apös o início da estação seca, perdurando atê depois do início da estação chuvosa. (Ver Fig. 4 .9).

Antecedendo ao período de deficiência, ocorre a retixada da ảgua armazenada no solo durante a estação chuvosa anterior portanto a deficiência faz-se sentir logo que o armazenamento hádrico cai pouco abaixo da "capacidade de campo".

Sempre que a curva $P$ aparece abaixo da curva EP no gräfico do Balanço Hîdrico, hä utilização da ägua disponîvel no so10 (retirada) até que se esgotem os $125 \mathrm{~mm}$ de ägua disponível ; a pôs o que se inicia o período de deficiência, que se prolonga atë que a curva $P$ ultrapasse a EP. Então ocorre o in sição da ägua no solo, atẻ que se atinjam os $125 \mathrm{~mm}$ e, a partir dai, ocorre o excedente hídrico.

A Fig. 4.7 mostra o balanço hîdrico executado pela RADAM BRASTL em seis postos situados em locais da area estudada. Em Natal, o ano inicia-se com uma deficiência hídrica de $118 \mathrm{~mm}$ que 

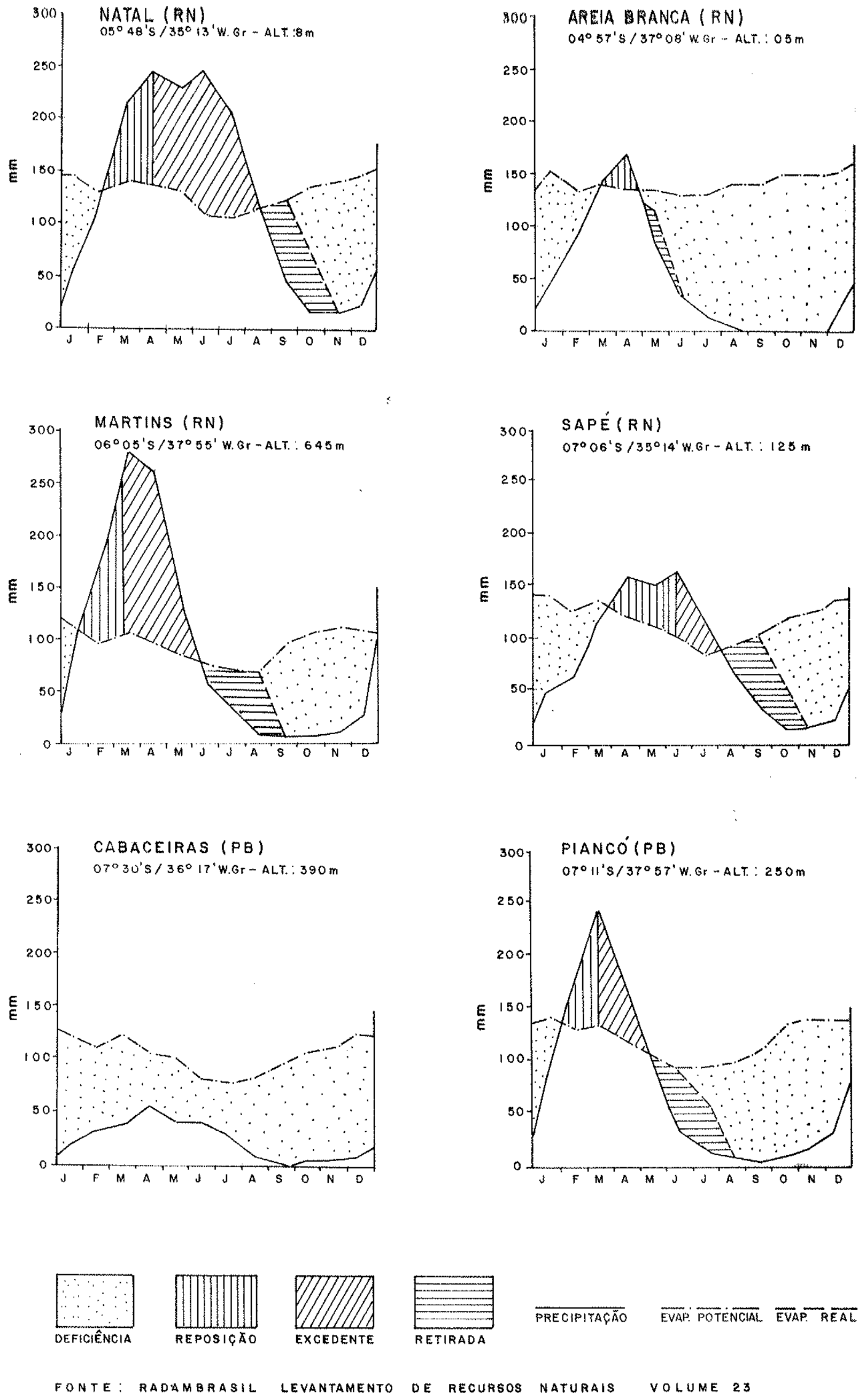

FIG.4.7 BALANGO HIDRICO DE THORNTWAITE 
$\vec{e}$ reposta nos meses de março e abril; os meses de abril, maio, junho e ju1ho representam excedente hîdrico de $388 \mathrm{~mm}$, passando nos meses de agcsto e setembro a se processar a retirada de agua do solo, voltando nos meses de outubro, novembro e dezembro a ter deficiência hîdrica, que somada a jä existente em janeiro e revereiro, atinge o total de $432 \mathrm{~mm}$. Do mesmo modo, podem ser analisadas as värias fases de recarga e retirada de ägua do solo nos demais postos apresentados.

\subsubsection{CJASSTFICAÇOES CLIMATTICAS}

\subsubsection{Classificação de Koppen}

A classificação de Koppen baseia se na precipitação, tem peratura e umidade do ar. Segundo essa classificação ocorrem os seguintes tipos de clima:

AS' - quente e ümido, com estação seca no verão e chuvas no outonominverno; domina o Iitoral do R,G.do Norte e Paraíba, ficando praticamente restrito à ärea das bacias sedimentares cos teiras, não participando portanto da ârea de estudo.

Bsh - semi-ärido quente, limita-se com o AS' e estendese para oeste atẻ as imediaçōes de Patos na Paraíba e Carnaubas no pio Grande do Norte.

Aw' - quente e ümido com chuvas de verão e precipitações mäximas no outono; compreende o restante da ärea para oeste.

4.2.7.2. Zoneamento Arido de E. DE Martonne

Esta classificação leva em conta apenas a precipitação e temperatura, estabelecendo "îndices de aridez" que variam desde a faixa de 0 - 10 atê a faixa de 50-60.

Esse zoneamento acha-se apresentado juntamente com o mapa de precipitação (isojetas) na Fig. 4.2 a fim de mostrar a in- 
tima relação entre os valores de precipitação e isolinhas de Indices de aridez. Assim $\vec{e}$ que os mais baixos indices de aridez, das zonas 1 e $2(<15)$ correspondem a uma faixa de direção apro ximadamente norte-sul, na qual ocorrem os mais baixos indices pluviomëtricos, chegando a $300 \mathrm{~mm} /$ ano nas regiōes de Cabaceiras e Soledadc. Essa faixa compreende, além das regiões supra citadas, ainda as de Sumê, Juazeirinho e Picui no Estado da paraîba e Cru zeta, Currais Novos, Lajes, São Tomë e Pedro Avelino, no Rio Grande do Norte.

Essa faixa dc aridez desempenha, como serâ visto adiante um importante papel no processo de salinização das äguas superfi ciais $c$, em consequência, as subterrâneas, visto que nele se sí tuam as cabeceiras de quase todos os rios que drenam de oeste pa ra leste.

\subsubsection{Classificação de Nimer}

Essa classificação foi aperfeiçoada pela equipe de estu* dos climatolôgicos do RADAMBRASIL que adotou subdivisões meso climâticas a partir dos seguintes elementos: indices de umidade de Thornthwaite, precipitação total anual, excedente hîdrico anual, nümero de meses com excedente hỉdrico, deficiência hídrica anual e números de meses com deficiência hídrica. Foi ainda procedido um tratamento estatístico das faixas úmidas e secas, gerando um îndice que foi denominado de distância taxonômica.

No Quadro NQ 4.2 são apresontados os diversos parâmetros quo caracterizam cada um dos 18 mesoclimas em que foram subdivididos os 6 climas regionais e na Fig. 4.10,são apresentados em mapa esses tipos de climas na região de estudo.

4.3. RELEVO E GEOMORFOLOGIA

o rolevo da ärea $\vec{e}$ relativamente monótono, pouco movimentado, representado na maior parte por superfícies de aplaina. mento - pediplanos - onde se assentam formas residuais ("morros, 
QUADRO 4.2 - PARAMETROS DAS VARIAÇOES MESOCLIMATICAS NO ESPAÇO CLTMATTICO REGIONAL

\begin{tabular}{|c|c|c|c|c|c|c|c|c|c|}
\hline $\begin{array}{l}\text { REF. } \\
\text { ESP. }\end{array}$ & $\begin{array}{l}\text { CLIMA } \\
\text { REGIONAL }\end{array}$ & $\begin{array}{l}\text { INDICE DE } \\
\text { UMIDADE } \\
(\mathrm{mm})\end{array}$ & $\begin{array}{l}\text { PRECIPITAÇAO } \\
\text { TOTAL ANUAL } \\
\text { (nom) }\end{array}$ & $\begin{array}{c}\text { EXCEDENTE } \\
\text { HIDRICO ANUAL } \\
\text { (mm) }\end{array}$ & $\begin{array}{l}\text { NOMESES } \\
\text { C/EXCED. } \\
\text { HTDRICO }\end{array}$ & $\begin{array}{c}\text { DEFICIENCIA } \\
\text { HIDRICA ANO } \\
\text { (Im) }\end{array}$ & $\begin{array}{l}\text { NOMESES } \\
\text { C/DEFIC. } \\
\text { HIDRICA }\end{array}$ & $\begin{array}{c}\text { TEMPERATURA } \\
\text { MEDIA ANUAL } \\
\left(9^{\circ} \mathrm{C}\right)\end{array}$ & $\begin{array}{l}\text { DISTÂNCIA } \\
\text { TAXONÔMICA }\end{array}$ \\
\hline 01 & & $60-100$ & $1.750-2.000$ & 1.200 a 1.400 & 5 & $100-200$ & 3 & 21 a 22 & 2,0 \\
\hline 02 & Omido & $60-100$ & $2.000-2.500$ & 800 a 1.200 & 5 a 6 & $200-350$ & 5 & 25 & 2,6 \\
\hline 03 & & $40-60$ & $2.000-2.500$ & 400 a 800 & 5 & $200-350$ & 4 & 25 & 2,9 \\
\hline 04 & Thido a & $20-60$ & $1.200-2.000$ & 400 a 1.200 & 3 a 4 & $200-350$ & 3 e 4 & 24 & 3 a 3,3 \\
\hline 05 & subümido & $20-40$ & $800-1.750$ & 100 a 800 & 4 a 6 & $200-350$ & 5 & 24 a 25 & 3,5 a 3,8 \\
\hline 06 & & $20-40$ & $800-1.200$ & $400 \mathrm{a} \quad 800$ & 5 a 6 & $350-500$ & 6 & 24 & 3,9 \\
\hline 07 & & $0-20$ & $1.200-1.500$ & $100 \mathrm{a} \quad 400$ & 3 a 4 & $350-500$ & 5 e 6 & 25 & 4,0 a 4,2 \\
\hline 08 & Subünido & $0-20$ & $800-1.500$ & 100 a 400 & 3 a 4 & $350-650$ & 6 & 27 & 4,0 a 4,5 \\
\hline 09 & & $0-20$ & $800-1.200$ & 100 a 400 & 2 a 3 & $500-750$ & 6 & $23-24-25$ & 4,7 a 4,8 \\
\hline 10 & Subümido & $0-(-20)$ & $800-1.200$ & 100 a 400 & 2 & $650-900$ & 6 e 7 & 26 a 27 & 5,0 a 5,3 \\
\hline 11 & semi-ärido & $0-(-40)$ & $800-1.200$ & $1 \mathrm{a} \quad 400$ & 1 a 2 & $350-900$ & 7 e 8 & $25-26-27$ & 5,4 a 5,6 \\
\hline 12 & & $(-20)-(-40)$ & $800-1.200$ & $1 \mathrm{a} \quad 400$. & 1 a 2 & $650-900$ & 7 e 8 & $25-26-27$ & 5,7 a 5,9 \\
\hline 13 & & $(-20)-(-40)$ & $500-1.200$ & $\begin{array}{ll}0 \text { a } & 100\end{array}$ & 1 a 2 & $500-1050$ & 8 e 9 & $24-25-26$ & $6,0 a 6,3$ \\
\hline 14 & Semi-ärido & $(-20)-(-40)$ & $500-800$ & 0 & 1 & $650-1050$ & 9 e 11 & $24-25-26$ & 6,4 a 6,6 \\
\hline 15 & & $(-20)-(-40)$ & $500-800$ & 0 & 0 & $900-1200$ & 9 e 11 & $23-25-26-27$ & 6,7 a 6,9 \\
\hline 16 & Semi-ärido & $(-40)-(-60)$ & $250-500$ & 0 & 0 & $750-900$ & 10 e 11 & 23 & 7,2 \\
\hline 17 & a ärido & $(-40)-(-60)$ & $250-500$ & 0 & 0 & $750-1050$ & 10 e 11 & 23 a 26 & 7,4 a 7,5 \\
\hline 18 & & $(-40)-(60)$ & $250-500$ & 0 & 0 & $1050-1200$ & 12 & 26 & 7,7 \\
\hline
\end{tabular}

Fonte: ME-Projeto RADAMBRASIL-Levantamento de Recursos Naturais-Vo1.23-1981 
"serras" e "serrotes" ) e ainda, extensas chapadas delimitadas por escarpas rclativamente abruptas.

As cotas variam desde pouco mais de $100 \mathrm{~m}$ (na ärea de rochas cristalinas)até $1.000 \mathrm{~m}$, sendo o ponto mais elevado - o pico do Jabre - situado na Serra do Teixeira, com $1.197 \mathrm{~m}$ de altitude.

O limite sul da ärea, correspondente ao limite entre os Estados da Paraîba e Pernambuco é marcado por "serras" com altitudes variảveis entre 800 e $1.200 \mathrm{~m}$, como a Serra do Teixeira, a Serra dos Cariris Velhos e a Serra dos Carixis Novos (Ver Fig. $4.2)$.

A feiçäo morfológica mais marcante da ärea é sem düvida - Planalto da Borborema que se acha dissecado em värios patanares a diferentes cotas. Destaca-se um conjunto de elevações na porção centro-sul, cabeceiras do rio paraîba, bem como ainda na região de Campina Grande, Soledade e Juazeirinho, prolongando-se esse conjunto de clevações, em forma de "serras" na direção norte atê a altura do paralelo $6^{\circ} 00^{\prime}$, onde se destaca a Serra do Santana. Em cotas mais reduzidas, de 300 a $500 \mathrm{~m}$, essa dorsal mor folögica se estende para nortc atê a região de Lajes e Pedro Ave lino no Rio Grande do Norte.

Essa feição morfolỏgica desempenha grande papel na clima tologia, na hidrografia e por extensão, na hidrogeologia das ro chas cristalinas. Na climatologia, devido a constituir barreiras para a circulação atmosfêrica dos ventos alíseos, acarretando com isso condições de sub-aridez na região; na hidrografia por nascerem ali os rios que dronam para a costa oriental, numa região de maior aridez, com excesso de evaporação sobre a precipi tação, o que provoca a salinização das suas äguas; por fim, as âa guas subterrâneas que são infiltradas jấ salinizadas, tendem a aumentar os teores de sais.

A análise da geomorfologia regional foi bem realizada por ALBUQUERQUE (1971) ao descrever o capitulo respectivo da folha n' 15 do Inventáxio Hidrogeolôgico Bâsico do Nordeste, que abran ge a maior parte da ärea do estudo atual.

Segundo Albuquerque, säo distinguĩveis na ärea, três a quatro aplainamentos, realizados por sucessivos rebaixamentos do níve1 de base, ou, o que $\vec{e}$ o mesmo, causados por movimentos epiro 
genëticos que, por etapas, afetaram a região (após a sedimentação consumada no (retăceo), provavelmente durante o Terciário.

A primeira superfície de aplainamento, e portanto, a superfície somital, tambëm chamada de cimeira, resultou, pois, da exaltação sucessiva da superfície de recobrimento sedimentar cre tăcica exposta à erosão fluvial, que exumou as formas colinosas prë-cambrianas de base, representadas hoje, pelos resíduos morfo lógicos mais altos (como o pico de Jabre). Esta superfície cimei ra foi denominada por KING (1956) por "Superfïcie Pós Gondwanà"; corresponde a Superfície do Teixeira, denominação dada por DEMANGEOT (1959) e a Pd3 de BIGARELLA \& AB'SABER (1961), citados por MABESOONE e CASTRO (1975).

A segunda superfície de aplainamento, cscalonada como as seguintes, abaixo da supcrfície somital, e elaborada a partir desta, está melhor representada na ärea por retalhos residuais com altitudes variando entre 750 e $850 \mathrm{~m}$, inclusive com depósitos correlatos: são as serras de Teixeira (PB) e Portalegre ( RN), Martins (RN), João do Vale (RN), Santana dos Matos(RN), Bom Bocadinho $(P B)$, todas com capeamento arenítico. Esta superfïcie tambêm foi identificada por KING que a denominou de ". Su1-Americana"; corresponde âs designações de "Superfî́cie dos Cariris"(DE MANGEOT) op.cit. e "Pd2" (BIGARELLA \& AB'SABER)op.cit.

o terceiro degrau do escalonamento geomorfológico $\overrightarrow{\mathrm{e}}$ re. presentado por uma superfî́cie com altitudes oscilando em torno dos $550 \mathrm{~m}$, apresentando-se como um pediplano mais ou menos contínuo, consumado pela coalescência de coluviões detrúticos acumula dos nas vertentes de maciços residuais. Essa superficie foi deno minada de "Gravatá" por RUELLAN em 1954, "CAMPINA GRANDE" ...por DRESCH, 1954 e "SOLEDADE" por MEUNTER, 1961, citados por ALBUQUERQUE, op.cit. Atualmente essa superfície é considerada comó $\underline{\mathrm{u}}$ ma sô unidade geomórfica com o quarto patamar, em torno dos $250 \mathrm{~m}$ de altitude, originalmente denominada por KING de "Superfície Ve 1has", e por AB'SABER (1969) de "Superfîcie Sertaneja", ou ainda "Pd1" de BIGARElla \& AB'SABER op.cit.

Toda essa variação de formas, de superfícies de aplainamentos e seus depôsitos correlatos, vêm a demonstrar a existência de paleo-climas muito variados, do ümido a sub-ümido, à semi ârido e atê mesmo ârido. 


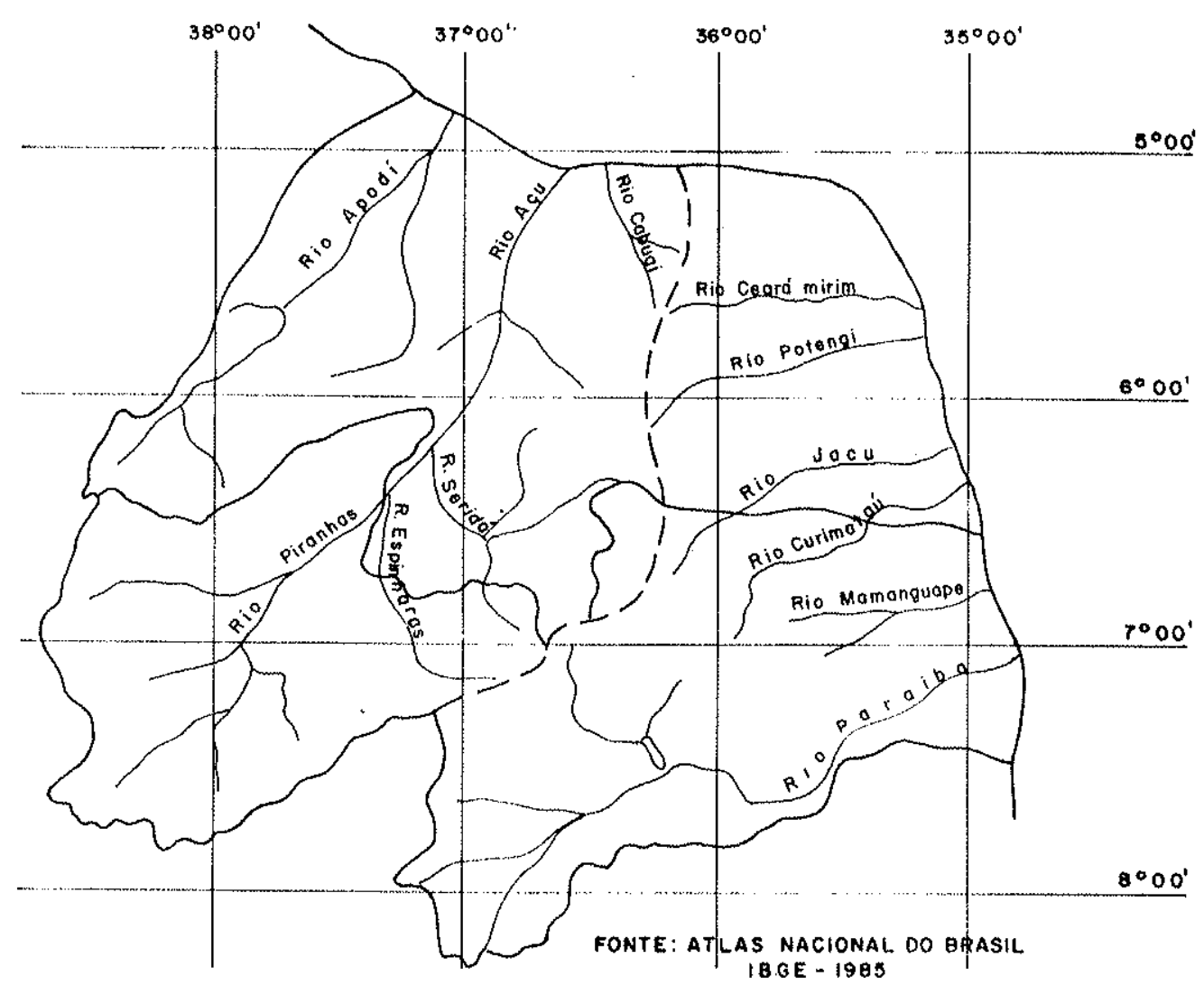

FIG. 4.11 - BACIAS HIDROGRÁFICAS DA ÁREA

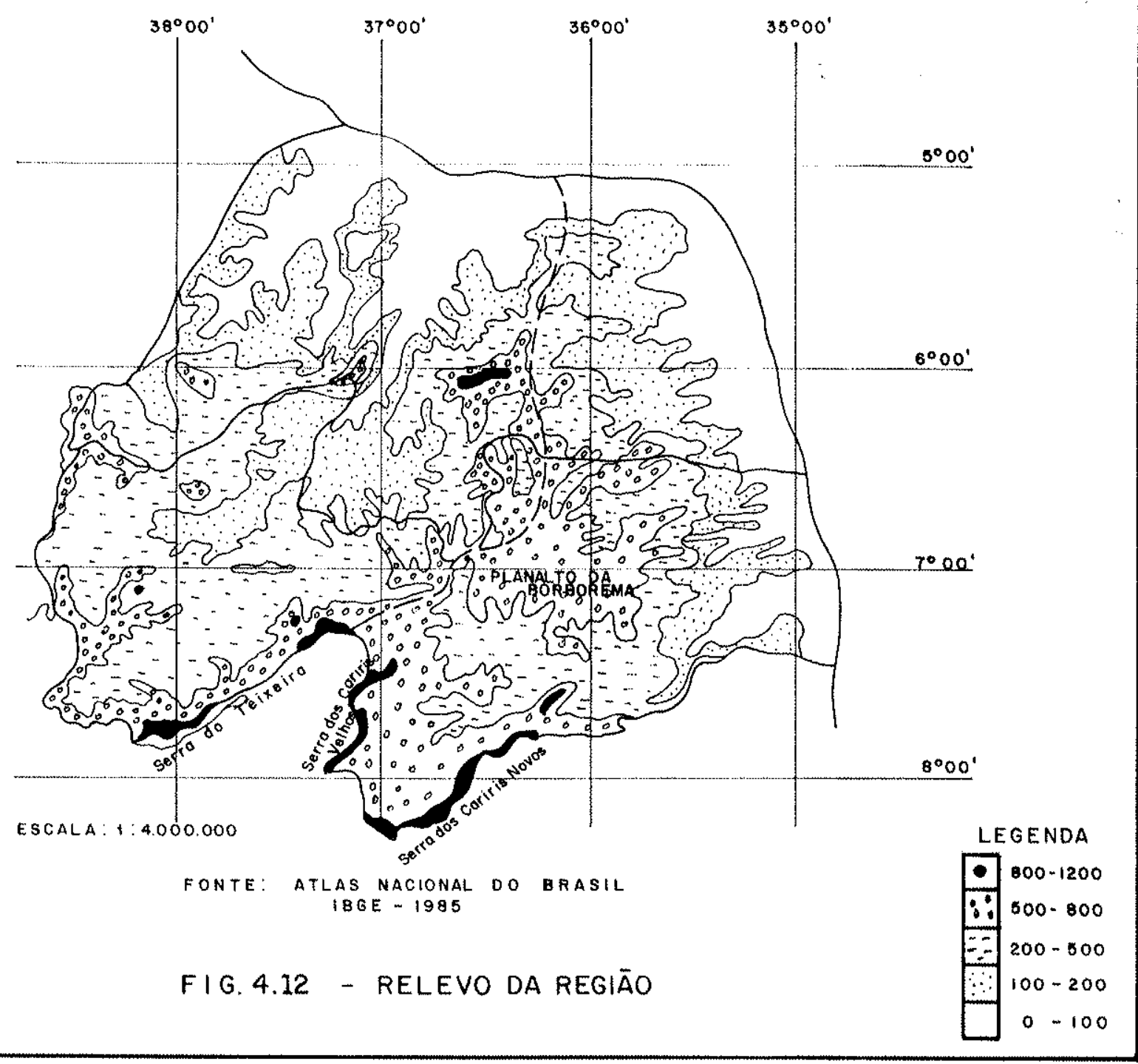


4.4. HTDROGRAFIA

Conforme jâ referido no ítem anterior, uma dorsal morfo1.ögica divide a área estudada em duas grandes regiões, bem carac terizadas hidrograficamente, que são: a região oriental, onde os rios drenam de oeste para leste, a partir da dorsal morfolögica - a região ocidental, na qual os cursos d'água são orientados de sul para norte (Ver Fig. 4.11).

$\Lambda$ s bacias hidrogräficas que pertencem às duas regiỏes, com respectivas äreas são as seguintes:

$$
\begin{aligned}
& \text { Rogião Ocidenta1: Bacia do Rio Apodi } \quad-18.142 \mathrm{~km}^{2} \\
& \text { " " "Piranhas (Açu)- } 38.393 \text { " } \\
& \text { " " Cabugi }-\frac{2.966 "}{59.501 "}
\end{aligned}
$$

Região Oriental: Bacia do Rio Cearä-Mirim - $4.421 \mathrm{~km}^{2}$

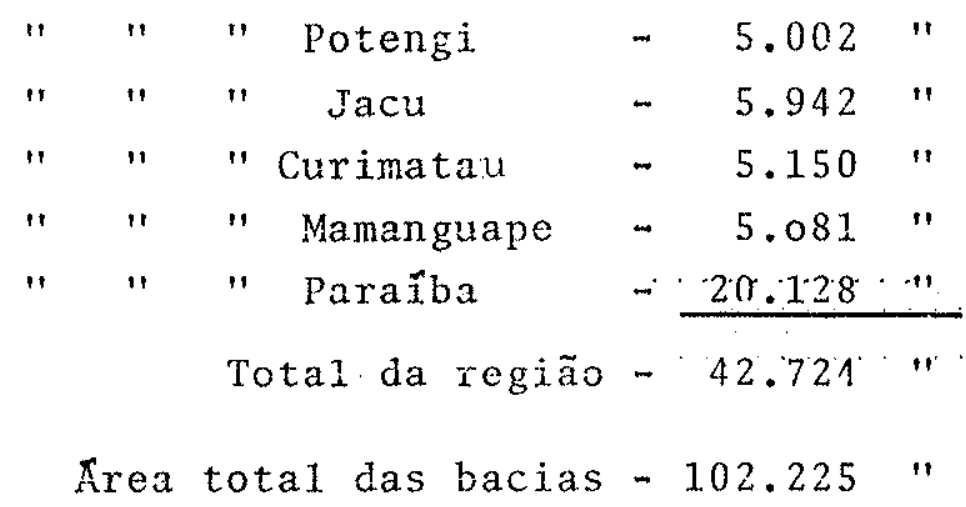

No Quadro 4.3 acham-sc apresentadas as caracteristicas de todas essas bacias.

\subsection{WOLO E VEGETACAO}

Na região da superficie dos $250 \mathrm{~m}$, os solos existentes são do tipo azonal, arenosos, argilosos, localizados, pertanto, nos leitos e terraços aluviais dos rios que os irrigam. Nos interflüvios o solo e nu10. Por outro 1ado, na superfície dos $500 \mathrm{~m}$ os solos são pouco espessos, ë verdade, mas formam uma capa rela tivamente continua, só interrompida pelos "monadnocks" grañ́ti - 
cos da superfície. São solos zonais, com "bed-rock" bem desenvol vido, de caräter relativamente argiloso.

$\mathrm{Na}$ região das chapadas, são essencialmente arenosos, pro venientes da decomposição direta da rocha sedimentar subjacente: o arenito Serra do Martins.

$\Lambda$ vegetação na superfície dos $250 \mathrm{~m}$ è baixa, rala, caracterizada pela predominância de gramíneas, leguminosas, malvảceas e secundariamente, de arbustos variados e algumas ärvores entremeadas de cactäceas. Säo exemplos: os capins panasco (Austida adscensionis) e mimoso ( Nnthephora hermaphrodita), e a Jurema ( Mimosa verrucosa), o pereiro (Aspidosperma pirifolium), o matapasto (Cassia uniflora), o capim de galinha (Dityloctenium aegyti um) o mufumbo (Combretum leprosum), o marmeleiro (Croton hemiargyreus), o Jcazeiro (Ziziphus joazeiro), o Ipê (Tccoma chrysotri cha), o angico (Piptadenia colubrina), entre outros.

$\mathrm{Na}$ superfície de $550 \mathrm{~m}$, a vegetação e mais densa, sendo esta a zona de predileção das Cactãceas e Bromeliāceas (dcvido à umidade do ar, principalmente noturno) entremeadas de arbustos e ārvorcs lenhosas, de caule duro e de porte maior, onde são exem-m plos o cardeiro (Cereus peruvianus), o xique-xique (Pilocereus laciniosa), coroa de frade (Melacactus bahienses), umbuzeiro spondia tuberosa), craibeira (Tabebuia caraiba), a barauna (Mela noxylon brauna), a palma forrageira (Opuntia ficus indica iner me,) ctc.

Quanto à região das serras, a vegetaçãc $\vec{e}$ densa, apesar da devastação, havendo aî, de importante, o descnvolvimento das chamadas lavouras xerófilas, das quais se destacam o sisal, a mandioca, algaroba, a palma forrageira,etc.

Toda a gama de variaçäo da vegetação, em todas as superfúcies, é caracterizada pelo fenômeno do xerofilismo. 
QUADRO 4.3 - CARACTERISTICAS PRINCIPAIS DAS BACIAS HIDROGRAFICAS DR REGIAO ESTUDADA

\begin{tabular}{|c|c|c|c|c|c|c|c|c|c|c|c|c|c|c|}
\hline \multirow{2}{*}{$\begin{array}{c}\text { BACTA } \\
\text { HIDPO } \\
\text { CREAI } \\
\mathrm{OA}\end{array}$} & \multirow{2}{*}{$\begin{array}{l}\text { FORMA } \\
\text { DAA } \\
\text { BACIA }\end{array}$} & \multicolumn{2}{|c|}{$\begin{array}{c}\text { DAMENSOES } \\
\text { (an) }\end{array}$} & \multirow{2}{*}{$\begin{array}{r}\text { AREA } \\
\mathrm{km}^{2}\end{array}$} & \multirow{2}{*}{ 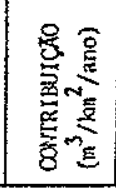 } & \multirow{2}{*}{ 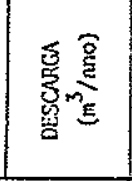 } & \multicolumn{3}{|c|}{ TIDOS IE DRENACOY } & \multicolumn{2}{|c|}{ PRANCIPAIS AEUENTES } & \multirow{2}{*}{$\begin{array}{c}\text { REGRIE } \\
\text { DE } \\
\text { ESCOANETTO }\end{array}$} & \multirow{2}{*}{$\begin{array}{l}\text { ACGDES } \\
\text { Of } \\
\text { BARRACENS }\end{array}$} & \multirow[b]{2}{*}{ OBSERVAÇOES } \\
\hline & & 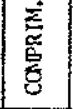 & 桑 & & & & $\begin{array}{l}\text { ALTO } \\
\text { CRSO }\end{array}$ & $\begin{array}{l}\text { MEDIO } \\
\text { CuRso }\end{array}$ & $\begin{array}{l}\text { BAIXO } \\
\text { aRSO }\end{array}$ & $\begin{array}{l}\text { MAREES } \\
\text { DIREITA }\end{array}$ & $\begin{array}{l}\text { MARGEM } \\
\text { ESQUERDA }\end{array}$ & & & \\
\hline Arpodi & Retanguiar & 210 & 80 & 18.142 & 80.400 & $1,46.10^{9}$ & Dendritica & \begin{tabular}{|l|} 
Dendritica \\
Angulada ou \\
Anastonosada
\end{tabular} & $\begin{array}{c}\text { Sub-paraleig } \\
\text { ou Anastonosa } \\
\text { da }\end{array}$ & $\begin{array}{l}\text { Carmo, pitombei } \\
\text { ras et thari }\end{array}$ & $\begin{array}{l}\text { Riacino Grande e } \\
\text { Bonsucesso }\end{array}$ & Internitente & Năo possti & \\
\hline Pirzitas & $\begin{array}{l}\text { Retarizular } \\
\text { a triang. } \\
\end{array}$ & 810 & 120 & 38.393 & 66.452 & $2,55.10^{9}$ & $\begin{array}{l}\text { Dendrítica } \\
\text { a Angulada } \\
\end{array}$ & Dendrítica & Parajeia & $\begin{array}{l}\text { Findoba, Seríäo, } \\
\text { Sabugi, Piancó }\end{array}$ & $\begin{array}{l}\text { Peixe, Parau, } \\
\text { Cavalos, Unbuzeixo }\end{array}$ & $\begin{array}{l}\text { Intermitente } \\
\text { parc.regular }\end{array}$ & 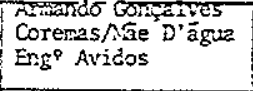 & \\
\hline$C_{3} b_{15}{ }^{i}$ & \begin{tabular}{|l|} 
Trianguiar \\
a quadrang.
\end{tabular} & 80 & 60 & 2.966 & 5.000 & $14,8.10^{6}$ & Convergente & $\begin{array}{l}\text { Paraleia a } \\
\text { Sub-paralela }\end{array}$ & $\begin{array}{l}\text { Paralela a } \\
\text { Sub-paraiela }\end{array}$ & Serra Asudia & - & Intemitenie & Nizo possui & \\
\hline Ceerä-Virm & fetangular & 120 & 35 & 4.421 & 61.380 & $273.10^{6}$ & \begin{tabular}{|l|} 
Anguiar a \\
Dendritica
\end{tabular} & Paralela & Paraleia & $\begin{array}{c}\text { Dois Imäos e } \\
\text { Tatu }\end{array}$ & Hexarangiape & Internitente & Vāo possui & $\begin{array}{l}\text { Perene no baixo Cirso } \\
\text { A.curso c/contr.estrut. }\end{array}$ \\
\hline rotengi & Retangular & 130 & 40 & 5.002 & 71.430 & $357.10^{6}$ & $\begin{array}{l}\text { Dendritica } \\
\text { a retangul. }\end{array}$ & $\begin{array}{l}\text { Dosdritica } \\
\text { a retangular }\end{array}$ & Paralela & Jundiai & $\begin{array}{l}\text { Pedra preta e } \\
\text { amaragibe }\end{array}$ & intermitente & Não possui & Icem: \\
\hline Jacu & Retangular & 140 & 40 & $5.9 \div 2$ & 37.160 & $220.10^{6}$ & $\begin{array}{l}\text { Retangular } \\
\text { a sub-dendr }\end{array}$ & $\begin{array}{l}\text { Retangular a } \\
\text { Sub-paralela } \\
\end{array}$ & Sub-paralela & - & Riacho Jacu & Internitente & Lagoas costeitas & Ferene no baixo curso \\
\hline Curi-ataus & Petangula: & 140 & 30 & 5.250 & 160.260 & $825.10^{6}$ & Dendritica & Angular & Paralela & Pirari & Calabouryo & $\begin{array}{l}\text { Perene quase } \\
\text { totalmente }\end{array}$ & Näo possui & \\
\hline Nkransape & Retangular & 120 & 30 & 5.080 & 292.555 & $1,48.10^{9}$ & Denúrítica & Angular & Paralela & - & $\begin{array}{c}\text { Jacaré e Bana } \\
\text { neiras }\end{array}$ & $\begin{array}{l}\text { Parcialmente } \\
\text { perenizado }\end{array}$ & Não possui & A.curso c/contr.sstrat. \\
\hline Paraibs & Itregulat & 260 & $\begin{array}{l}100 \\
250\end{array}$ & 20.128 & 37.620 & $1,56.10^{9}$ & $\begin{array}{l}\text { Dencrítica } \\
\text { e radial. }\end{array}$ & $\begin{array}{l}\text { Dendritica a } \\
\text { e anguiar }\end{array}$ & $\begin{array}{l}\text { Dendrïtica a } \\
\text { Paralela }\end{array}$ & Gramare & $\begin{array}{l}\text { Wrinhes, Ingá } \\
\text { Solecade, Tapera }\end{array}$ & $\begin{array}{l}\text { Perene a jus } \\
\text { açude }\end{array}$ & Aç. Boqueiräo & · \\
\hline
\end{tabular}


CAP ITULO NO 5

GEOLOGIA H GEOTECTONICA DA AREA 


\subsection{INTRODUCAO}

O nordeste brasileiro, como um compartimento fisiogeográ fico, compreende os Estados do Piaui, Cearä, Rio Grande do Norte, Paraiba, Pernambuco, Alagoas e Sergipe; o nordeste, encarado sob o ponto de vista geológico, corresponde a Província Borborema, Ii mitada a noroeste pelo cráton de São Luis, a oeste pela Provín cia Parnaiba e ao sul pela província São Francisco, que correspon de ao cräton São Francisco.

Bordejando a costa, ocorre a província Costeira represen tada por bacias sedimentares costeiras de idade cretäcica, depo sitadas sobre o embasamento cristalino da Provincia da Borborema.

Como nordeste oriental, compreende-se uma ärea represen tada pela totalidade dos estados do Rio Grande do Norte e Parai ba e parte dos estados do Ceará e pernambuco, abrangendo um to tal de aproximadamente $200.000 \mathrm{~km}^{2}$.

Inicialmente, serão apresentadas e caracterizadas todas as feições da Provincia Borborema, todos os seus dominios geotec tônicos, para a seguir, ser procedida uma anälise lito-estratigra fica e estrutural da ārea de interesse.

\subsection{A COMPARTTMENTACAO GEOTECTONICA DA PROVTNCIA BORBOREMA}

Como Provincia Borborema, definida por ALMEIDA et a1ii (977,1981), entende-se "uma entidade de mobi1idade tectono-termal no Ciclo Brasiliano" caracterizada por possuir limites convencio nais de dois nücleos cratônicos sinbrasilianos, o são Francisco (ao sul) e o são Luis (ao norte).

A Provincia ê subdividida em domínios, que vizam indivi dualizar conjuntos 1ito-estratigräficos que possuem determinadas características geológicas, geotectônicas, magmatogenéticas e me talogenëticas.

os domínios por sua vez, compreendem duas feições bem distintas, que são:

a) os terrenos gnäissico-migmatítico-granitos, denomina dos de maciços; 
b) os terrenos metassedimentares e meta-vulcano-sedimen tares, ou cinturões de matamorfitos, que constituem os sistemas de dobramentos.

os elementos estruturais desempenham importante papel no arcabouço reológico-tectônico da província, sendo destacados os grandes lineamentos resultantes de falhamentos transcorrentes e as geofraturas, as quais delimitam muitos dos compartimentos su pra assinalados.

Dentre os magmatitos, os plutonitos ocorrem de maneira muito destacada, porém os vulcanitos são muito restritos o que confere ao geossinclinal regional a característica de essencial mente terrígeno (BRITO NEVES,1975).

Finalmente, deve-se mencionar as coberturas sedimentares que se mostram distribuidas de maneira esparsa, com variações 1 i. tológicas e estruturais e distribuidas durante todas as eras geo logicas.

5.2 .1 . LIMITES DA PROVINCIA: OS CRATONS

Os sitios geológicos que podem ser considerados como li mites da Província Borborema, ou seja, os crätons que ocorrem ao norte - São Luis - e ao sul - São Francisco, não constituem a ri gor, uma plena delimitação de toda a sequência lito-estrutural da província. De fato, se forem levados em conta os limites ori ental e ocidental, constata-se que o embasamento da Província cos teira, de constituição sedimentar, ê o mesmo conjunto de maciços e sistemas de dobramentos de direção E-W e NE-SW. Inclusive, se tem reconhecido no continente africano - região de Gana e Gabão, estruturas que provavelmente constituem a continuidade dessa pro víncia, uma representação prē-deriva bem marcante.

por outro lado, o sistema provinciano também se estende para oeste, sob a Sinéclese do Parnaiba (Provincia Parnaiba) não se conhecendo os seus termos 1 imítrofes com precisão.

Atê mesmo o contato com o Craton do São Francisco ao sul, não ê bem definido em toda a sua extensão. Apenas na região do Baixo Vaza-Barris/Curaça, a delimitação é bem marcada entre a Faixa Sergipana e seu antepais, porēm mais para sudoeste, no Mé dio São Francisco, "as deformações mais recentes parecem suavizar 
gradativamente de norte para sul, configurando pois limite tipo transiciona1" (BRITO NEVES, 1983).

\section{$5.2 .1 .1-\underline{\text { C Cräton de São Francisco }}$}

Esse núcleo cratônico antigo, se bem que jả viesse sendo conceituado desde trabalhos anteriores (EBERT, GUIMARAES e outros) somente foi devidamente formalizado por ALMEIDA(1967) "definindo esta vasta ärea do nordeste e leste brasileiros como plataforma das faixas de dobramentos sircum-adjacentes" (BRITO NEVES, op cit).

Como principal representação 1ito-estratigräfica presen te nesse nücleo, destaca-se no Arqueano o Complexo Caraíba (BAR BOSA, 1964) constituido por migmatitos, leptinitos com rochas ba sicas e ultra-básicas associadas. Mais recentemente, é denomina. do de Complexo Metamórfico-Migmatitico(SGHOBENHAUSS, et alii,1984).

o Proterozóico inferior marca a presença de estreitos cin turōes de sequências metassedimentares e vulcano-sedimentares,co mo sejam:

- Complexo Colomi - constituido por quartzitos, metarcó seos e metarenitos na base, passando verticalmente para dolomi to e calcário dolomitico e voltando a meta-sedimentos psamíticos no topo da sequência

- Complexo Barreiro - compreende uma sequência vulcanosedimentar de fäcies xisto verde com filitos e metapelitos na ba se, passando a metavulcânicas ácidas a intermediárias e metasse dimentos, no topo.

- Complexo Rio Salitre - abrange filitos, xistos, metar cóseos, metagrauvacas, quartzitos, metabasitos e metatufos. - Complexo Itapicuru - constituido por filitos, xistos, cherts, itabiritos, metassiltitos e quartzitos.

Associados ocorrem ainda os granitốides de composição va riada, gerados ou reativados no ciclo Transamazônico, dentre eles destacando-se o batólito de Campo Alegre de Lurdes.

\section{$5.2 \cdot 1.2-0$ Cräton de São, Luis}

Esse cräton mais superior foi inicialmente detectado por ALMEIDA(1967) atravês das primeiras determinações radiométricas 
ali realizadas. Dos estudos posteriores de CORDANI(1968) e ALMEI DA et alii(1973) à base de radiometria e anảlise geotectônica,fi cou ratificado o conceito de nücleo cratônico para aquela região, de consolidação no ciclo transamazônico.

Lito-estratigraficamente, è representado pe1o Complexo Mara cuçumi (ABREU et alii,1980) do Arqueano, constituido por gnaisse e migmatitos, secundados por granitos e granodioritos e, encaixa do por falhamentos nesse complexo, uma faixa de filitos, quartzi tos e xistos, que representam o Grupo Gurupi do Proterozóico in ferior.

5.2.2. OS DOMTNIOS GEOTECTONNTCOS

A Província Borborema acha-se dividida em 5 (cinco) domínios, assim denominados, do sul para norte:

a - Dominio Sergipano (BRITO NEVES, 1975 e ALMEIDA et a1ii, 1977)

b - Dominio Centro-Oriental (BRITO NEVES, 1975 e ALMEIDA et a1ii, 1977) ou Extremo Nordeste(SCHOBBENHAUSS, et a1ii, 1984)

c - Dominio Centra1 (BRITO NEVES, 1975 e ALMEIDA et a1ii,77) ou Transnordestino (SCHOBBENHAUSS, et alii, 1984)

d - Domínio Jaguaribeano (BRITO NEVES, 1975 e ALMEIDA et a1ii 1977) ou Cearense(CHOBBENHAUSS et alii, 1984)

e - Dominio Rio Coreau(BRITO NEVES; et a1ii,1975 e ALMEIDA et alii,1977) ou Médio Coreau (SCHOBBENHAUSS, et al 1984).

Conforme pode ser visto na Fig.5.1, verifica-se uma disposição simétrica desses domínios geológicos, sob o ponto de vista geotec tônico, como se segue:

- Domínios externos (Sergipano e Coreau) - limites da provín cia junto aos núcleos cratônicos, apresentando uma disposição " a proximadamente diagonal entre si (direções NW-SE e NE-SW) respec tivamente). Apresentam como característica comum, a ausência qua se total de rochas granitóides (que constituem os maciços de ou tros domínios) e presença exclusiva da sequência metassedimentar de baixo grau, dobradas, incluindo rochas carbonáticas. 


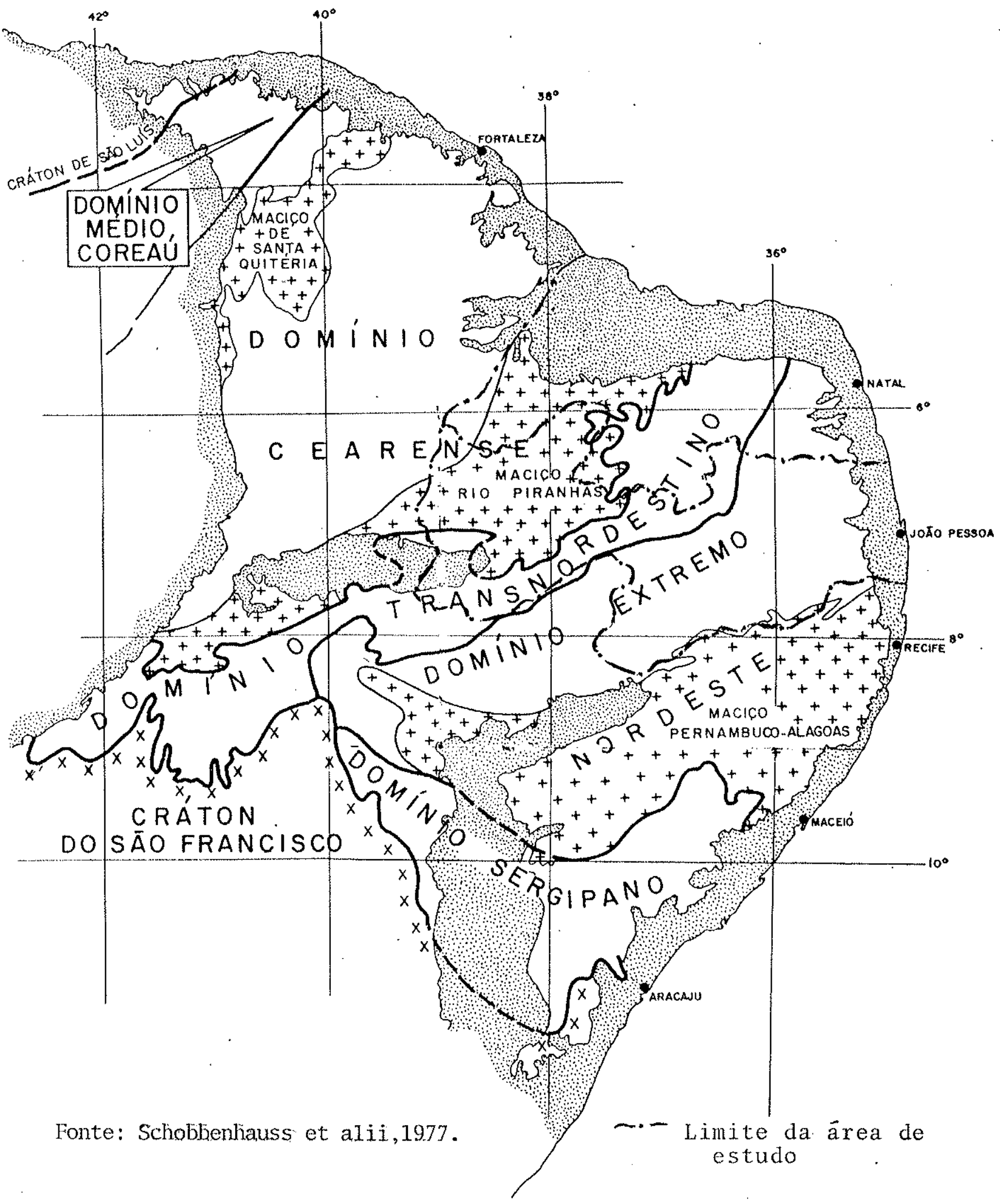

Fig. 5. 1-Domínios estruturais da região de dobramentos Nordeste. 
- Domínios intermediärios (Extremo Nordeste e Cearense) esses domínios, que se limitam respectivamente com o Sergipano e Coreau, apresentam extensas exposições de terrenos gnäissicos-mig matíticos ou migmatitico-graniticos, isto é, de rochas infracrus tais. Paralelamente ou entremeados com esses maciços cristalinos, ocorrem faixas ou bandas de metamorfitos dobrados ("sistemas ves tigiais") de pequenas dimensões e descontínuas.

- Domínio Central(ou Transnordestino), que atravessa toda a região nordeste, sendo 1 imitado lateralmente pelos domínios inter mediärios. Caracteriza-se pelo predomínio de metamorfitos epi e mesozonais, com estruturas dobradas, cortadas por corpos granito des descontínuos, de formas variadas e extensões limitadas. Esse dominio pode ainda ser subdividido em três subdomínios contíguos a saber (de sudoeste para nordeste):

- Riacho do Pontal - no Estado de pernambuco

- Piancó-Alto Brígida - no Estado da Paraiba

- Seridó - no Estado do Rio Grande do Norte.

\subsubsection{SISTEMAS DE DOBRAMENTOS E MACIÇOS}

Essas duas feições geológicas apresentam-se de modo aproxi madamente alternadas, distribuidas em zonas mais ou menos linea res e radiais, formando um leque estrutural entre os extremos no roeste e sudeste da Província Borborema. De tal modo e esse arran jo, que todos os sistemas, inclusive os extremos, alcançam a 1 i nha da costa perpendicularmente (Ver Fig.5.2).

A terminologia de "sistema de dobramentos" constitui uma tra dução do termo "folded belt", representando terrenos metassedimen tares e meta vulcano-sedimentares dobradas, tambẻm designado de "cinturões metamörficos".

Os sistemas de dobramentos são classificados em interiores e marginais. Nos primeiros, hä predominância da litologia psamí tica e pelitica: quartzitos, micaxistos, filitos, metassiltitos, etc, com rochas calcárias e cálcio-silicáticas ocorrendo subordi nadamente, alëm de metavulcanitos associados. Nos sistemas marg nais, embora ocorram tambêm as sequências terrígenas, predominam as rochas carbonáticas.

Os sistemas de dobramentos marginais, identificados na regi ão, foram o Sergipano e o Mẻdio Coreau (nos domínios respectivos); 


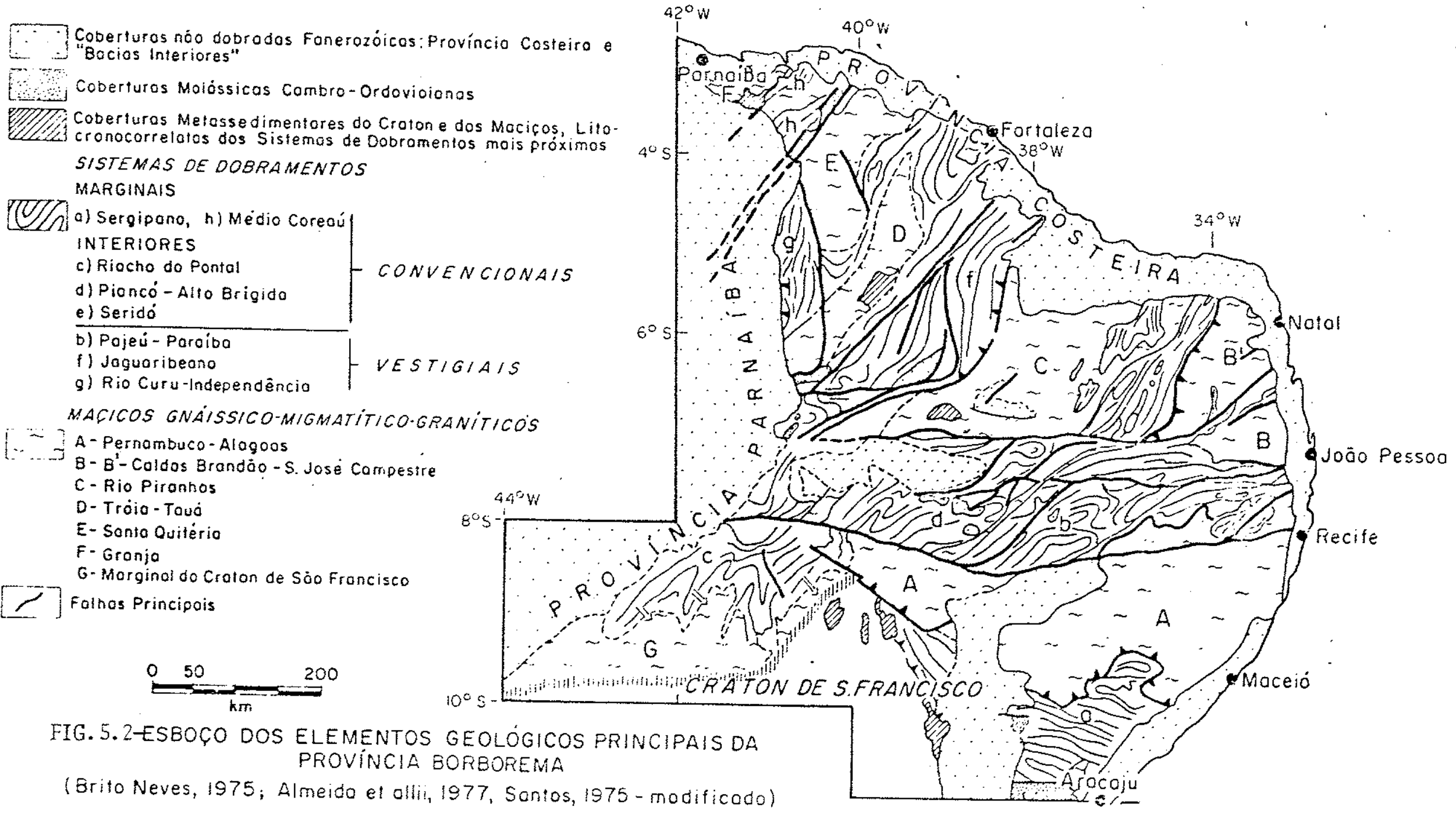


quanto aos sistemas de dobramentos interiores, foram individuali zados os seguintes: Riacho do Pontal, Piancö-Alto Brígida, Seri dô, Pajeü-Paraiba, Jaguaribeano e Rio Curu-Independência (Fig.7.2)

Quanto ao modo de ocorrência desses cinturōes metamórficos em relação aos maciços de rochas do embasamento, podem ser os sis temas de dobramentos classificados em sistemas convencionais ("oro genic belts") e sistemas vestigiais ("Vestigial facets"). Nos pri meiros ocorre a nitida predominância dos metamorfitos dobrados, com os estägios estratigräficos bem preservados e exposições do embasamento, restritas. Nos segundos, o "embasamento se expõe ex tensivamente, restringindo as 1itologias supracrustais a faixas estreitas ("schist belts") ou a localização determinada e pouco expressiva em ärea" (BRITO NEVES,1983). Conforme se vê na Fig.5.2, corresponde aos sistemas de dobramentos convenvionais, o Sergipa no, o Medio Coreau (Marginais) e Riacho do ponta1, Piancó-A1to Brígida e Seridó (Interiores); ao sistema de dobramento vestigial correspondem o Pajeú-Paraiba, Jaguaribeano e Rio Curu-Independên cia.

O metamorfismo dominante $\vec{\theta}$ o regional do tipo plurifacial, ocorrendo ainda o metamorfismo de contato nas auréolas dos corpos intrusivos e o dinamometamorfismo associado às zonas de geofratu ras.

A classificação geotectônica que mais se adequa ao caso é a de "mobile belt" de vez que o termo "geossinclíneo" tem geradoin tensas controvērsias.

Os maciços são representados pelos terrenos gnáissico-migma títico-graniticos que se alternam com as faixas de matamorfitos dobrados, e dele se distinguem por características 1itolögicas, estruturais, metamórficas, etc.

Embora de formas bastante variadas, desde ovalar, a poligo nal, ou irregulares, os maciços podem ser classificados em marginais e interiores. Os primeiros, são aqueles que guardam intima relação com as áreas cratônicas sinbrasilianas mais próximas, co mo são os casos do Maciço de Granja ao norte,vinculado ao Craton São Luis e o Maciço Frontal do Craton de São Francisco ao sul.os segundos se acham alternados com os sistemas de dobramento, sen do comum se observar a extensão destes terrenos na infra-estrutu ra dos terrenos meta-sedimentares. Säo os casos dos maciços pex 
nambuco-Alagoas nos Estados de mesmo nome, Caldas Brandão-S.Josë do Campestre nos Estados da Paraiba e Rio Grande do Norte, Rio Pi ranhas no Estado do Rio Grande do Norte, Tróia-Tauá e Santa Quité ria no Estado do Ceará.

A natureza litológica dos maciços gnáissico-migmatíticos é bastante variada em função da derivação (ortometamorfitos, para metamorfitos,etc), sendo difícil a distinção para os maciços mig matítico-graníticos com 1 ineaçōes metamörficas obscurecidas.

Embora ocorram muitas vezes em äreas de grande extensão, sen do tratados como imensos batólitos, é comum tambéma ocorrência de formas de dimensões modestas ("stocks", bo1sas, etc) alēm de diques e outras manifestações ígneas menores. A composição é qua se sempre granitica, ocorrendo também granodioritos e sienitos e em menor escala, de rochas bảsicas e ultrabäsicas como é o caso do maciço Tróia-Tauâ.

Quanto ao enquadramento desses maciços na classificação geo tectônica; BRITO NEVES(1983) mostra que há uma grande diversifi cação de designações, tais como: maciço, maciço mediano, zonas centrais e atê mesmo micro placas e microcrätons. O mesmo autor, admite como "interessante e mencionável" a classificação adotada por WINDLEY,1979, de "Complexo graníticomigmatítico".

\subsubsection{FALHAMENTOS E LINEAMENTOS REGTONAIS}

0 aspecto estrutural mais marcante no complexo cristalino do nordeste, é a presença de Iineamentos e geofraturas. o primeiro a chamar a atenção desses falhamentos de dimensão regional, aos quais chamou de lineamento, foi $\operatorname{KEGEL}(1961,1965)$. Posteriormente, EBERT( (1962) enfatizou a importância dos lineamentos de pernambu co e Paraiba na estruturação regional, definidos numa faixa de direção $\mathrm{E}-\mathrm{W}$, a que denominou de "zona transversal". Värias contri buições posteriores, como BARBOSA et a1ii(1970), SANTOS (1971), BRTTO NEVES(1975) e MELLO(1979) destacaram o seu caräter transcor rente, reconhecendo-1he, entretanto, o caräter policíclico, com reativações atë no Mesozóico.

No mapa da Fig.5.3.observa-se os principais Iineamentos estru turais e geofraturas regionais. A primeira vista, constata-se que duas direções são dominantes: a dos lineamentos pernambuco, patos 


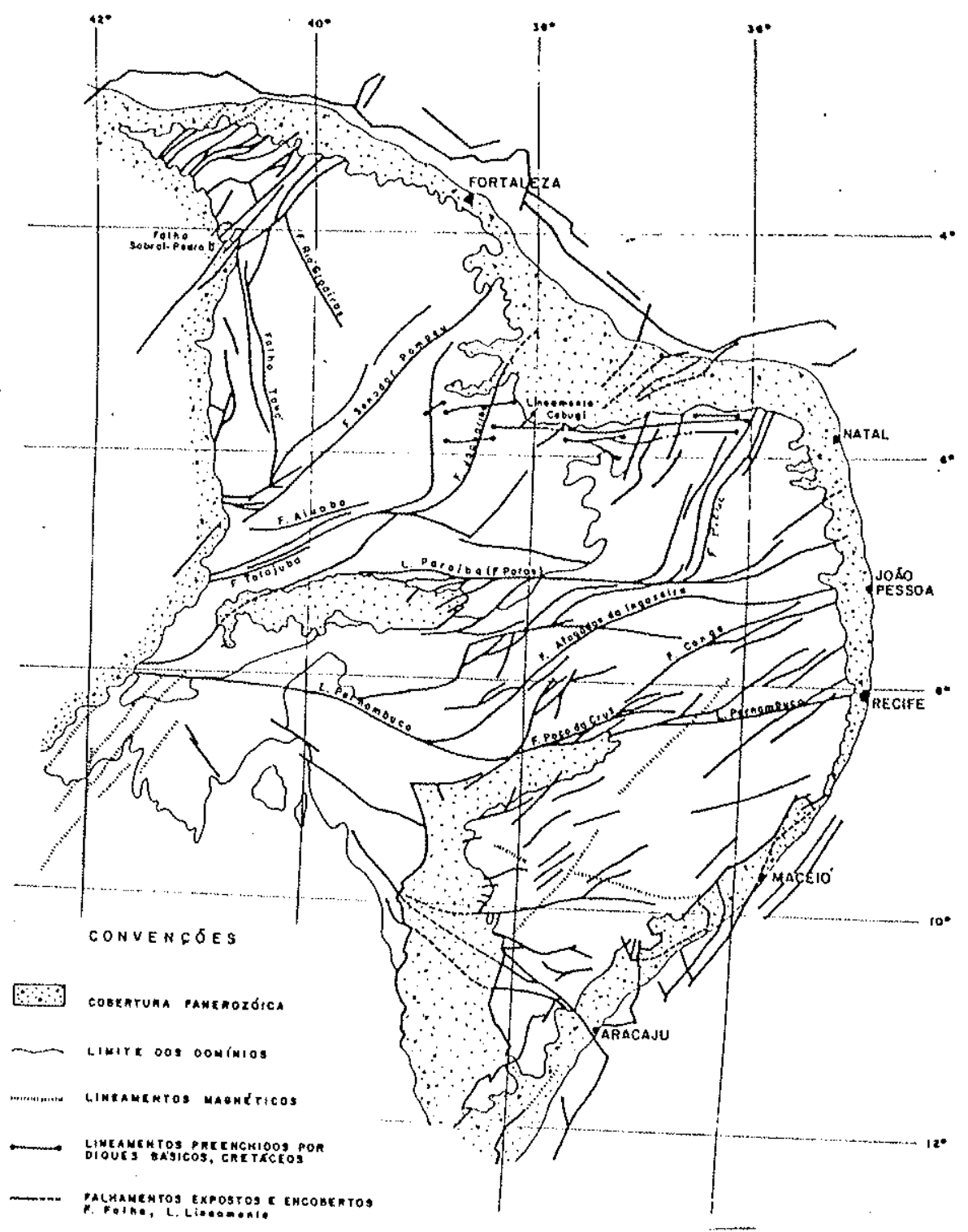

Fig. 5 . Principais falhamentos e lineamentos da regiāo de dobramentos Nordeste.

Fonte: Schobbenhauss, et alij, 1977 
e Cabugi com direção $I:-W$ e as das falhas Sobral-pedro II, Senador Pompeu, Serra Talhada, Afogados da Ingazeira, Congo, com direção NE-SW. Outras direções menos frequentes são a de N-S a NNW-SSE, representadas pelas falhas Tauá, Rio Groairas, Orós e Jaguaribe, todas no Dominio Cearense e as direções WNW-ESE a ENE-WSW ocor rentes no Domínio Sergipano.

Tanto os 1 ineamentos como as falhas apresentam diferentes características de extensão, ativações policíclicas, variações de tipo e intensidade de rejeito no tempo e no espaço geográficogeológico, relações com o magmatismo, etc.

O caráter policíclico ê frequente sobretudo nos lineamentos, onde se constata reativação em planos de fraqueza transcorrente, com falhamentos gravitacionais acarretando a formação de fossas com deposição de mais de $2.000 \mathrm{~m}$ de sedimentos, como é o caso do bordo norte da bacia de Jatobá, delimitado por uma fal ha normal no plano do lineamento Pernambuco.

Também o 1ineamento Cabugi apresenta-se a partir do Cretäceo com os planos inteiramente regelados por intrusões de diques bási cos, evidenciando esforço tracional, provocado por basculamento ocorrido no bordo setentrional do continente (que teria dado ori. gem a formação da Bacia Potiguar).

SANTOS et alii, in SCHOBBENHAUS et alii,1984, admitem que o estágio inicial de esforços, tenha sido tracional, de rifteamento crustal intraplaca, que teria evoluido para falhamentos compressi vos, de empurrão e transcorrência no estägio de fechamento dos ma res proterozóicos, com a colisão das placas brasilianas em jogo. Jä no inficio do paleozöico, esses falhamentos teriam voltado a as sumir um comportamento tracional, com a formação das molasses bra silianas, regime que elas herdariam definitivamente, nas subsequen tes reativações fanerozóicas.

o caräter principal dos grandes lineamentos e geofraturas re gionais $\vec{e}$ o seguinte:

a) Lineamentos Pernambuco e Paraiba(Patos) - movimentação transcorrente de direção $E-W$, com fases precedentes e sub sequentes de esforço compressivo de direção N-S e tracio nais tambëm $\mathrm{N}-\mathrm{S}$, com intrusões magmäticas de caräter äci do e afundamentos (falhas normais).

b) Lineamento Cabugi - movimentação vertical por basculamen 
to do bloco setentrional, com aberturas tracionais e in trusões magmäticas de caräter básico.

c) Lineamento Sobra1-pedro II - movimentação crustal com fa lhamento de gravidade devido a esforços tracionais, acar retando acumulações de milhares de metros de sedimentos molássicos de Jaibaras; associadas a esse linemento ocor rem inumeras falhas paralelas, transcorrentes.

d) Falha de Picui - de direção NNE-SSW, delimita o Maciço Caldas Brandão-S.J.Campestre do Sistema de Dobramentos do Seridó e tem o carâter de uma falha de empurrão (in versa) com vergência de SE para NW.

e) Falha Jaguaribe - de mesma direção à anterior, delimita - Maciço Rio Piranhas do Sistema de Dobramentos do Jagua ribe (Domimío Cearense) e tem o caráter de uma falha de empurrão (inversa) com vergência de WNW para ESE.

5.3. O DOMTNIO EXTREMO NORDESTE OU CENTRO-ORIENTAL

Conforme já aludido, esse domínio, igualmente ao Cearense, a presenta uma nítida predominância dos maciços sobre os sistemas de dobramentos. O seu limite com o domínio Sergipano é pouco di ferenciado, pois a partir do eixo do maciço Pernambuco-Alagoas (na altura do paralelo 9900') "começam a aparecer os reflexos mag máticos e tectônicos do envolvimento da borda deste maciço na èo 1ução da faixa Sul Alagoana"(BRITO NEVES,1983). Quanto a delimita ção com o domínio Central ou Transnordestino, é marcado ao norte pela falha de Picui, continuando para sudoeste atraves da dorsal. granitico-migmatítico de Teixeira, e falha Afogados da Ingazeira (Figs. 51, 5.2 e 5.3 )

o domínio pode ser dividido em três partes mais ou menos dis tintas, apesar das interações existentes entre elas: o Maciço Cal das Brandão-São José do Campestre (norte), o Maciço Pernambuco-A lagoas (sul) e o Sistema de Dobramentos Pajeü-Paraiba (centro).

5.3.1. MACICOO CALDAS-BRANDAO-SAO JOSE DO CAMPESTRE

Inicia-se na região de Caldas Brandão na Paraiba, prolongan 
do-se para norte atravês de São Josê do Campestre, presidente Juscelino e João Câmara no Rio Grande do Norte.

E caracterizado por possuir uma "trama estrutural complexa, disposição transversal aos "trends" NNE-EW da Província e idade Proterozöica Inferior a Prê-Proterozóica" (BRITO NEVES, 1983)(op cit).

Extensas faixas gnäissicas e metatexíticas, de direção $\mathrm{N}-\mathrm{S}$ a NE-SW, com intercalações de leptinitos, anfibolitos e alguns calcários, circunscrevem grandes núcleos ovóides, semicirculares e poligonais, constituidos de diatexitos associados a granitöides sincinemáticos. Estes nücleos, como os de Natal, presidente Jus celino, Cacimba de Dentro, Campina Grande, Mari-Caldas Brandão, etc., destacam-se (tambëm topograficamente) dos gnaisses e metate xitos que os envolvem.

\subsubsection{MACIÇO PERNAMBUCO-ALAGOAS}

A designação dessa unidade 1 ito-estrutural é de autoria de BRITO NEVES(1975) em substituição às designações de "Batólito Per nambuco-Alagoas" (SCHALER, 1969) e "Maciço de Itaiba" (SANTOS,1971) que tiveram utilização restrita, por uma série de razões.

Possui uma forma triangular, com base situada na zona costei ra e eixo com direção variando entre WNW-ESE e WSW-ENE. Do ponto de vista tectônico, constitui um típico maciço mediano do primei ro tipo, que serviu de antepais dos sistemas de dobramentos adm jacentes, que para ele dirigem centripetamente a vergência. Seu limite setentrional $\vec{e}$ marcado em parte pelo "lineamento Pernambu co" e na totalidade pelos contatos com metamorfitos das faixas de dobramentos brasilianas; ao sul, sua delimitação também é feita com a faixa de dobramentos sergipana.

Litologicamente, é constituido de terrenos gnáissico-migma títicos orto e para derivados e por grandes maciços migmatiticograniticos (granodioriticos). Intrusivas calco-alcalinas, em for ma de "stocks" e pequenos batölitos, associados ao plutonismo dos sistemas confinantes ocorrem esparsamente. Rostos de cobertura me tassedimentar (quartzitos e micaxistos) podem ser observados na parte central (Garanhuns) e partes marginais dos maciços ali em butidos por ações tectônicas ou como remanescentes de processos de granitização. 
predominam as rochas migmatiticas com estruturas variadas, principalmente flebíticas, secundariamente estromatítica, oftalmí tica e nebulitica, com composição modal granodiorítica mais co mum, alêm de granítica, tonalítica, quartzo-diorítica e mesmo di oríticas, de difícil separação cartogräfica mesmo em escala de detalhe. Alëm de gnaisses e migmatitos, tem-se encontrado,nessas faixas, esporädicas ocorrências de anfibolito e rochas de fäcies granulito.

Os maiores complexos batölitos do nordeste, ocorrem nesse maciço, resultantes de sucessivos ciclos de geração de granitos, com culminação provâvel no Ciclo Brasiliano. Uma série de corpos graniticos, quartzo-sienitos e sienitos corta os terrenos de al to grau deste maciço, principalmente na sua borda sul, ligados à evolução da ifáixa de Dobramentos Sul Alagoana (BRITO NEVES,1983).

5.3.3. STSTEMA DE DOBRAMENTOS PAJEU-PARAIBA

Esse sistema ë representado por faixas descontinuas e de reduzida extensão. A faixa que margeia ao norte o maciço Pernam buco-Alagoas foi denominado por BRITO NEVES $(1973,1975)$ de faixa Pajeü-paraiba, sendo composto por um complexo litoestratigräfico descrito por BARBOSA et alii(1970) e FERREIRA \& ALBUQUERQUE(1969) sob as designações de Grupos Uauá e Caicó. Estudos posteriores e de maior detalhe, levaram SANTOS(1971,1977) a redefini-1os na re gião central de pernambuco, englobando-os no Complexo do Alto Moxotó. Esse complexo, de idade arqueana, compreende três sequênci as 1itoestratigräficas: Feliciano, São Caetano e Sertânia.

A sequência Feliciano é uma unidade migmatítica com heran ça máfico-ultramāfica; a fäcies regional é um gnaisse de composi ção diorítica e tonalítica e em algumas regiões (Poço da Cruz) 은 correm dioritos e gabros com intercalações de märmore. A sequên cia São Caetano corresponde a um conjunto de xistos e gnaisses, leptinitos e quartzitos, abundantes na região limítrofe central. de pernambuco e Paraiba.

A sequência Sertânia é representada predominantemente por biotita-gnaisses com intercalações de anfibolito, quartzito, lep tinito e märmore, ocorrendo principalmente em Santa Cruz do Capi barjbe, e Taquaritinga do Norte. 
No Proterozóico ocorrem resquícios de faixas metamörficas dobradas, predominantemente xistosas e quartziticas. Os micaxis tos foram descritos por SANTOS $(1971,1977)$ que os designou de Micaxistos tipo Caroalina e os correlacionou à Formação Serido. Com preendem micaxistos mesozonais com almandina e sillimanita, meta grauvacas xistosas e xistos a duas micas. Filitos e clorita xis tos são presentes nas äreas de Santa Cruz do Capibaribe e Soleda de.

5.4. O DOMINTO TRANSNORDESTINO OU CENTRAL

Esse domínio, como pode ser visto na Fig.5.2, apresenta três características bem peculiares:

19) e constituido apenas de faixas de dobramentos, sem ma ciços

$\left.2^{\circ}\right)$ ocupa a porção central da Província đa Borborema

$\left.3^{\circ}\right)$ acha-se segmentado pelos 1 ineamentos patos e pernambu co em três compartimentos ou subdomínios que são os sistemas de dobramento Seridó a nordeste, piancó-Alto Brígida no centro e Riacho do Pombal a sudoeste.

5.4.1. SISTEMA DE DOBRAMENTO SERIDO

Esse sistema constitui o segmento geolögico mais importan te e mais bem estudado do nordeste. A sua individualização como unidade geotectônica foi proposta por SUSCYNSKI(1966) embora jä tenha sido objeto de värios estudos anteriores, por EBERT(1955 e 1964), MEUNTER(1964) dentre outros.

Limita-se a leste com o Maciço S.J.Campestre-Caldas Bran däo, atravess da falha de Picui, a oeste com o Maciço Rio Piranhas por contato transicional e impreciso; ao norte é recoberto pela Bacia Potiguar e ao sul pela geofratura de patos (1ineamento).

Esse sistema pode ser subdividido em três distintos com partimentos geotectônicos/paleogeolögicos que se dispõem em fai xas paralelas dispostas na direção NE-SW a NNE-SSW e separadas por altos do embasamento, às vezes designadas de "zonas geanticli 
nais" (SANTOS, 1973; BRITO NEVES, 1975). Essas faixas são denomina das de leste para oeste como: Frei Martinho, Cruzeta e AngicosJucurutu, separadas pelos altos de Acari (a primeira da segunda) e São Vicente (a segunda da terceira).

o embasamento arqueano do sistema Serido aflora nas zonas de altos supramencionadas e em alguns altos interiores, além dos maciços limitantes do sistema. ocorre em forma de nücleos ovalói des designados de Complexo Caicô (MEUnIER, 1964) e Complexo São Vi cente (EBERT,1968).

o Complexo Caicó é constituido por metassedimentos gnáisisi cos, xistos, quartzitos, paranfibolitos e calcários, com migmati tos e rochas graniticas associadas. Estruturalmente, é caracteri zado por um dobramento semiplästico, com frequência de braquido bras, lineações sinuosas com um "trend" geral NNE a N-S e planos axiais raramente verticais (SCHOBBENHAUS et alii, 1984).

o Complexo São Vicente é representado predominantemente, por migmatitos e plagioclásio-gnaisses, com mergulhos fortes de fo liação gnáissica, alëm de gabröides e dioritöides.

Quanto a litoestratigrafia do Sistema de Dobramentos Seai dó, tambëm denominado de Grupo Seridó, ocorrem muitas controvêr sias entre as diversas colunas apresentadas. Três unidades são descritas pelos vários autores, a saber: Formação Seridó, Forma ção Equador e Formação Jucurutu, sendo a constituição de cada u ma dessas formações, a seguinte:

- Formação Seridó biotita xisto e muscovita-biotita xisto, a granada e/ou cordierita predominante, às vezes com andaluzita, silimanita e estaurolita. Localmente, ocorrem sericita e clorita.

- Formação Equador: muscovita quartzitos com fäcies arco seanas, itabiritos, metaconglomerados oligo a polimicto. Biotita xistos, mármores e cảlcio-silicatos e paranfibolitos aparecem no topo da formação.

- Formação Jucurutu: paragnaisses quartzo-feldspáticos,bio tita e hornblenda gnaisses, gnaisses a epidoto e metarcóseos. In tercalações e gradações para quartzitos, cälcio-silicáticas mine ralizadas (schellita), märmores, xistos, anfibolitos, leptinitos, cá1cio-xistos e presença de ortoanfibolitos e tremolita-actinoli ta $x$ istos.

A posição estratigrâfica dessas três unidades é controver 
tida, com exceção da Formação Seridō, que ocupa o topo da sequên cia. As formações Equador e Jucurutu são dispostas por alguns au tores com a Equador na base e por outros com a Jucurutu no início da coluna estratigräfica. Uma proposta de conciliação, foi apre sentada (SANTOS,1981), pela qual a Formação Equador (sedimenta ção nerítica, espessa e praticamente restrita à faixa oriental) passaria lateralmente por variação de fảcies à Formação Jucurutu a oeste.

5.4.2. SISTEMA DE DOBRAMENTOS PIANCO-ALTO BRIGIDA

o Sistema de Dobramentos Piancó-Alto Brígida, conforme po de ser visto na Fig.5.2, acha-se limitado ao norte e ao sul pelos Iineamentos de Patos e Pernambuco respectivamente; à leste 1imi. ta-se pelo eixo de rochas gnäissicas-migmatíticas e graníticas de Teixeira-Serra Talhada ("Zona Geanticlinal de Teixeira") e a oeste pelo maciço Rio Piranhas.

O embasamento do sistema só se expõe fracamente nos seus flancos. Ao norte, na borda do Maciço Rio Piranhas, predominam rochas migmatiticas e rochas granulares de paleossoma básico (di orito e quartzo dioritos) a intermediäria, cataclasadas e miloni tizadas, ao longo da zona arqueada situada entre as fal has de Mal ta e patos. Ao sul, ao longo da "Zona geanticlinal de Teixeira", predominam gnaisses graniticos e migmatíticos, circunscrevendo autênticos batölitos sincinemáticos (BRITO NEVES,1983).

Litoestratigraficamente, destaca-se o Grupo Cachoeirinha representado por filitos com conglomerados locais e vulcanitos associados (riolitos, dacitos, andesitos e piroclastos) interca lados com "chest" hematitico e piritoso, grauvacas e folhelhos, metamorfizados na fácies xisto verde.

5.4.3. SISTEMA DE DOBRAMENTOS RIACHO DO PONTAL

Constitui o extremo sudoeste do Dominio Centra1, 1imitan do-se ao norte com o lineamento Pernambuco, conectado com o sis tema de Dobramentos Piancó-Alto Brígida; para sul o seu embasa mento se identifica com o Craton São Francisco; a leste, a sepa ração com o Sistema Sergipano se faz por uma projeçāo arqueada 
do embasamento e para oeste e sudoeste, o tipo de vinculação com - Sistema de Dobramentos Rio Preto não ê bem conhecido.

o embasamento do sistema é um complexo migmatítico-gnáissi co contendo massas disformes de rochas bäsicas e ultrabäsicas.os migmatitos são diatexiticos e metatexíticos enquanto os gnaisses são de vários tipos, como biotita-gnaisses, gnaisses graníticos, gnaisses quartzo-feldspäticos e augen-gnaisses. Ocorrem ainda ro chas granitóides (granitos, adamelitos e granodioritos) em forma de "stocks" e batôlitos alongados.

A litoestratigrafia do sistema está intimamente relaciona da à do Sistema Piancó-Alto Brígida. Com efeito, o Grupo Salgueiro,aqui presente, ê um equivalente do Grupo Cachoeirinha descrito atrás. Nesse grupo, SANTOS \& CALDASSO(1977) descreveram três uni dades denominadas de "gnaisses de Rajada", "metapsamitos de Afrâa nio" e "xistos verdes de Monte Orebe".

os paragnaisses de Rajada são do tipo muscovítico ou bio títico, ricos em feldspato e gradam para quartzitos, quartzo-xis tos, biotita-muscovita-clorita xistos e filitos quartzosos. Em contato gradacional com estas rochas aparecem os xistos verdes de Monte Orebe, contendo xistos anfiboliticos, intercalações de quartzitos com anfibólio e diopsídio.

5.5. O DOMTNIO CEARENSE OU JAGUARIBEANO

Embora possuindo tanto maciços como faixas de dobramentos, os primeiros são predominantes, com exposições gnäissicomigmatí ticas e migmatítico-graniticas. Una importante característica do dominio é a concentração de geofraturas no interior (Tauä, Rio Groairas, Senador Pompeu, Orôs, etc), nas cercanias das zonas ex ternas (Sobral, Jaguaribe-Pau dos Ferros, Patos/Malta, Paulistana/ Pernambuco) .

Conforme se vê na Fig.5.1, foram identificados nesse dominio os seguintes maciços e sistemas de dobramentos:

- Maciço Santa Quitêria

- " Tróia-Tauá

- "Rio piranhas

- Sistemas de Dobramentos Vestigiais 
Constitui o bloco mais oriental, ou norte-oriental do do minio, sendo formado predominantemente por rochas migmatíticas, com estruturas metatexiticas e facoidais nas suas margens e dia texíticas no seu interior. Ocorrem ainda meso e catametamorfitos representados por gnaisses a anfibólio e biotita,biotita xistos granadiferos com muitas intercalações de quartzitos e rochas cá1 cio-silicáticas. Diversos corpos graníticos intrusivos cortam es ses metamorfitos, destacando-se entre eles o "plug" granodioriti co porfirítico da Serra da Barriga. A esse complexo conjunto 1íti co, CAMPOS et alii(1976) denominou de Complexo Tamboril-Santa Qui téria, tendo nele sido identificadas cinco fases de deformação por MENDONÇA et a1ii(1982).

5.5.2. MACIÇO DE TROIA-TAUA

Igualmente ao anteriormente descrito, predominam aqui os migmatitos com forte herança mäfico-ultramâfica. Ocorrem tambëm gnaisses anfibolíticos, anfibolitos e xistos autofilíticos e tre moliticos.

Nesse maciço, destaca-se o Complexo Tndependência, caracte rizado pelas interlaminações de gnaisses e anfibolitos, com inter calações de xistos a anfibólio, clorita e tremolita, quartzito com magnetita, cálcio-silicatos, etc. Corpos gabróides cortam esta sequência vulcano-sedimentar sendo também migmatitizados.

\subsubsection{MACIÇO RIO PIRANHAS}

Constitui um dos mais importantes maciços do nordeste, tan to pela sua extensão, como pelos conhecimentos dele auferidos, co mo ainda pela diversificação 1ito-estrutural que apresenta.

$\mathrm{Na}$ porção oriental e no embasamento do Sistema Seridô,foi identificado o "Complexo Cáicô" , de idade arqueana, constituido por um contexto meta-vulcânico-plutônico-sedimentar, que inclui paragnaisses arcoseanos quartzíticos, gnaisses granadiferos, orto gnaisses anfiboliticos, gnaisses graniticos, micaxistos, etc, com horizontes subordinados cálcio-silicáticos e carbonáticos. 
Na parte sul, ao longo do lineamento Patos, o maciço Rio Piranhas mostra grande contingente de rochas básicas e intermedi arias (dioritos, quartzodioritos, granodioritos) com variāvel grau de migmatitização.

$\mathrm{Na}$ porção ocidental e no embasamento do Sistema Jaguaribe ano, reaparecem gnaisses granodioríticos a tonalitos bandados e gnaisses graniticos a granodioriticos, cortados por corpos grani ticos, porfiroblásticos a hornblenda.

\subsubsection{OS SISTEMAS DE DOBRAMENTOS VESTIGIAIS}

Värias associações Iitológicas são destacáveis nesses sis temas de dobramento: o Complexo Independência, o Grupo Cearâ, o Complexo Lavras da Mangabeira e o Complexo Orōs.

- Grupo Ceará: termo introduzido ainda por Crandal1 no fi nal do sëculo passado, porêm de maneira muito genërica, è aqui $\underline{u}$ tilizado para designar um conjunto de micaxistos e gnaisses gra nadíferos, com ou sem quartzito basal e com intercalações de mär more. Na região de Apuiares o grupo está inserido em bacias intra domos; na ärea de Ibuaçu-Independência, os quartzitos se interca lam nos xistos, e na região de Independência os xistos contêm si limanita e/ou cianita alēm de rutilo, presente em venulações quart zosas. A fajxa de Arneirós apresenta quartzitos e leptinitos, en quanto a de Dois Riachos apresenta espessa massa de märmore.

- Complexo: Independência: é constituido por gnaisses ban dados, gnaisses leucocräticos, biotita e/ou hornblenda gnaisses e em menor proporção, leptnitos e gnaisses facoidais; incluem in tercalações de quartzitos, metarcóseos, metagrauvacas, anfiboli tos, biotita e anfibólio xistos, tremolita-clorita-xistos, meta basitos e märmore. Esses gnaisses caracterizam-se por um bandamen to gnäissico bem formado e pela ausência de processos anatëticos.

- Complexo Lavras da Mangabeira: compreende um grupo de e pimetamorfitos preservado em pequenas bacias com uma certa parti cipação de rochas mäfico-ultramäficas. Na seção inferior é cons tituida por gnaisses com intercalações de máfico-ultramáfica, an fibolitos, talco-xistos e serpentinitos; a seção mediana é cons tituida de micaxistos com intercalações de quartzitos e märmores dolomiticos; a sequência superior é composta por filitos com ní 
veis grafitosos.

- Complexo Orôs: caracteriza-se estruturalmente por uma forte linearidade e uma grande extensão, relativamente à pequena espessura do pacote metassedimentar. E constituido por quartzitos ao norte, e filitos no centro e sul, associado a mármores magne sianos, dolomitos e magnesita. 
PARTE 3:

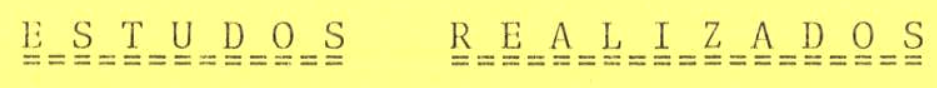


CAPITULO N? 6

TRATAMIENTTO DOS DADOS LEVANTADOS 
6.1. CONSTDERACOESS GERATS

Foram levantados 1.500 poços para toda a ärea de estudo, distribuídos 842 no Rio Grande do Norte e 658 no Estado da Paraí ba.

Desses poços, foram cadastrados apenas aqueles possuido ros do àgua, em nümero de $443(52,6 \%)$ no R.G. do Norte e 400 $60,8 \%$ ) na Paraíba. Para efeito de classificação como"poço seco ", foi considerado o limite de $2001 / \mathrm{h}$ ao final do teste de vazão de $24 \mathrm{~h}$ consecutivas.

Esse valor limite é muito variävel de acordo com a pesquisa considerada ou ainda com a finalidade a que se destina.Com efeito, considerando o uso domiciliar, um poço de vazāo inferior a $2001 / \mathrm{h}$ pode ser aproveitado atravês de uma captaçäo singela, com bomba pistão manual (ou elëtrica), podendo-se obter volumes diärios de 1.000 até 3.0001 itros, o que ê plenamente suficiente para atendimento residencial ou mesmo de uma pequena fazenda rural.

A elevada taxa de insucessos, superior a $40 \%$ na mëdia ge ral da regiảo não deve ser encarada como resultado de imperícia tëcnica na locação dos poços, a não ser em alguns poucos casos. Dentre as razőes constatadas, para justificar esse elevado percentual de poços secos, podem ser citados, na ordem decrescente de ocorrências :

1\%) Influência externa na locação, exercida sobretudo por políticos da região, que exigem a perfuração do poço em 1ocais não recomendados pe10 tëcnico responsäve1. A estrutura polí tica da companhia, diretamente 1igada a administração püblica es tadual, não permite aos têcnicos uma total 1 iberdade de ação no mister da locação do poço.

29) A proppria anisotropia do aquífero fissural que muitas vezes apresenta boas caracteristicas pelas feições superfici ais, porêm apresenta-se impermeâvel internamente (em profundidade). As vezes uma locação é realizada observando-se todos os cri térios têcnicos, o poço atravessa värias fraturas, porëm são todas secas ou com um volume irrjsório de ägua.

$\left.3^{\circ}\right)$ Inexperiência de alguns têcnicos que ainda não tềm prätica suficiente e cometem alguns enganos na locação do po 
ço deixando de observar alguns indícios desfavoräveis no local escolhido.

$\left.4^{\circ}\right)$ Outras causas eventuais, como por exemplo, o proprietärio mudar o local onde o têcnico colocou a estaca, indicando ao sondador um outro local maís próximo à sua residência.

o Cadastro dos poços com ägua, é apresentado em anexo e possui alëm das caracterîsticas tëcnicas do poço, contidas nas fichas elaboradas pelas respectivas companhias perfuradoras, a1guns dados complementares relacionados à pesquisa ora desenvolvi da.

Assim è que constam os dados locacionais, iniciando-se com o nümero de ordem ségundo numeração corrida, separada por Estado ( a do R.G. do Norte a partir de 1.000 e da Paraíba inici ando-se com 2.000 ), constando tambēm o nümero de referência da companhia executante. Seguem-se o local e município, as coordena das geogräficas e a data de perfuração (mês/ano).

Os dados geolögicos constam do nome da rocha, do tipo de material de cobertura e respectiva espessura, do tipo de fratura que ocorre na superficie, e das profundidades em que foram detec tadas fraturas no poço, e ainda o tipo de relevo associado a dré nagem superficial e por ûltimo o resîduo seco (ou sôlidos totais dissolvidos) da âgua do poço.

Vêm a seguir os dados tểnicos do poço, tais como profun didade, nîve1 estätico, nîvel dinâmico (do teste de vazão), vazão e vazão específica.

Quanto aos dados complementares de tipo de fratura e relevo associado a hidrografia, não constam para todos os poços ca dastrados. Foi escolhida uma área de $42.350 \mathrm{~km}^{2}$, 1 imitada pelas coordenadas geogräficas $360^{\circ} 00^{\prime}$ a $38^{\circ} 00^{\prime}$ Long.W.Gr. e $5030^{\circ}$ a $7^{\circ} 15^{\prime}$ Lat. Sul na qual havia sido executado um projeto de scheeli ta pelo DNPM/CPRM com mapeamento geológico bâsico na escala de 1:100.000 (BARBOSA e LIMA, 1980). Essa ârea que representa 50\% da ârea total de estudos, abrangeu 246 poços nos dois Estados, o que representa uma amostra de cerca de $30 \%$ da população estudada 


\subsection{ZONEAMENTO DOS POCOS NA AREA ESTUDADA}

0 zoneamento dos poços foi levado a efeito em função da diversificação da qualidade da âgua, visto que as demais caracte rísticas do aquífero não diferem sistematicamente de uma região para outra, como serä visto adiante.

Por outro lado, há uma intima relação entre a qualidade das äguas superficiais e as subterrâneas, como não podia deixar de ser, visto serem estas alimentadas por aquelas.

Tanto no Estado do R.G. do Norte como no Estado da Para íba, ocorre uma distinta variação na qualidade das äguas dos rios que drenam para o oriente, desaguando na costa leste do nordeste para aqueles que drenam para o norte, desaguando na costa setentrional do nordeste. Assim ê que as bacias hidrogräficas de maior curso que correm de oeste para leste, como os rios Ceara Mirim e Potengi no R.G. do Norte , e Paraíba, Jacu e Curimatau, na Paraîba, possuem äguas com elevados teores de salinidade. Enquanto isso , os rios que drenam de sul para norte, como o piranhas que nasce no extremo oeste da Paraíba e deságua no centro-. norte do R.G. do Norte, e o Apodi que drena todo o setor ocidenta1 desse Estado, possuem águas de baixos teores de salinidade.

Em vista disso, foi efetuado um zoneamento em duas granHes regiões, denominadas de Região Oriental e Região Ocidental. o limite entre as duas regiões, que constitui o divisor hidrogrā fico das bacias que drenam para leste ou para norte, passa aprom ximadamente no meridiano $36^{\circ} 16^{\prime}$ desde a altura de Lajes (RN) até - paralelo 7000' logo acima de Soledade. Daî, toma uma direção SW atê a cidade de Teixeira, prolongando-se pela Serra do Teixei ra em limite com o Estado de Pernambuco.

As bacias hidrogräficas que pertencem às duas regiões, na ärea de estudo jâa foram descritas no cap.4.4.

Dessas bacias hidrogräicas, duas desempenham maior importância pela sua extensão e ärea de domînio : a do Rio Pira nhas ou $\Lambda$ çu, que perfaz cerca de $18.500 \mathrm{~km}^{2}$ de superficie de rochas cristalinas e a do Rio Paraíba, que drena aproximadamente $1.7 .500 \mathrm{~km}^{2}$ de rochas cristalinas. 
A distribuição de poços cadastrados por regiões (incluindo os dois Estados), ficou assim: na região oriental 372 poços, equivalendo a $44.1 \%$ do total da ärea de estudo e na re gião ocidental, 471 poços, correspondendo a $55,9 \%$ do total estudado.

6.3. ANALTSE DOS ELEMENTOS DO CADASTRO DE POCOS

No Quadro $n^{\circ} 6.1$, são apresentados os valores estatís ticos dos principais parâmetros registrados para os poços pelas respectivas companhias de perfuração, sendo a seguir analisados individualmente cada um desses parâmetros, inclusive aqueles que não constam do referido quadro resumo.

0.3.1. TIPO DE ROCHA

As rochas em que foram os poços perfurados, constam da ficha do poço, tendo cerca de $20 \%$ deles sido visitados em viagem de campo durante essa pesquisa, o que constituiu, por amostragem, numa verificação da confiabilidade de classificação pe trográfica do cadastro existente. Deve ser salientado que, nessa verificação apenas $3 \%$ dos poços visitados sofreram modificação no tipo litolôgico classificado, o que representa um bom nîvel de confiabilidade dos dados existentes.

As rochas classificadas, com nümero de incidência e percentual do global para cada Estado e para a área total, são aprosentadas no Quadro 6.2 .

6.3.2. MANTO DE COBERTURA

Como manto de cobertura serão tratados indistintamente os materiais autôctoncs ou eluviöes, originados de processos de intemperismo da própria rocha (sem transporte) e os materiais a!- 
QUADRO 6.1 - VALORES MEDIOS REPRESENTATIVOS DOS PARÂMETROS DOS POÇOS

\begin{tabular}{|c|c|c|c|c|c|c|c|c|c|c|c|c|}
\hline \multirow{2}{*}{$\begin{array}{l}\text { PARAMETROS } \\
\text { ESTATIS } \\
\text { TICOS }\end{array}$} & \multicolumn{3}{|c|}{ ESPESSURA CAPEAMENTO (m) } & \multicolumn{3}{|c|}{ PROFUNDIDADE (m) } & \multicolumn{3}{|c|}{ NIVEL ESTATTICO (m) } & \multicolumn{3}{|c|}{ NIVEL DINAMICO (m) } \\
\hline & $\begin{array}{l}\text { R.G. } \\
\text { NORTE }\end{array}$ & $\begin{array}{r}\text { PARA } \\
\text { IBĀ }\end{array}$ & TOTAL & $\begin{array}{l}\text { R.G. } \\
\text { NORTE }\end{array}$ & $\begin{array}{r}\text { PARA } \\
\text { IBA }\end{array}$ & TOTAL & $\begin{array}{l}\text { R.G. } \\
\text { NORTE }\end{array}$ & $\begin{array}{r}\text { PARA } \\
\text { IBA }\end{array}$ & TOTAL & $\begin{array}{l}\text { R.G. } \\
\text { NORTE }\end{array}$ & $\begin{array}{r}\text { PARA } \\
\text { IBA }\end{array}$ & TOTAL \\
\hline Minima & 0 & 0 & 0 & 23,00 & 20,00 & 20,00 & $+3,80$ & $+0,80$ & $+3,80$ & 1,80 & 3,91 & 1,80 \\
\hline Mäxima & 19,00 & 12,00 & 19,00 & 101,00 & 78,00 & 101,00 & 31,00 & 24,24 & 31,00 & 48,33 & 46,00 & 48,33 \\
\hline Mëdia & 3,85 & 2,42 & 3,17 & 54,57 & 46,06 & 50,53 & 5,17 & 4,56 & 4,87 & 23,13 & 16,59 & 19,97 \\
\hline D.Padrão & 3,04 & 1,91 & - & 10,31 & 6,72 & - & 4,76 & 3,19 & - & 13,23 & 7,27 & - \\
\hline Coef.Var. $\left(\frac{\circ}{0}\right)$ & 78,95 & 79,06 & - & 18,90 & 14,59 & - & 92,11 & 70,05 & - & 57,19 & 43,84 & - \\
\hline Niamostras & 431 & 391 & 822 & 443 & 440 & 843 & 428 & 396 & 824 & 425 & 396 & 821 \\
\hline
\end{tabular}

( Continuação)

\begin{tabular}{|c|c|c|c|c|c|c|c|c|c|c|c|c|}
\hline \multirow{3}{*}{$\begin{array}{l}\text { PARANMETROS } \\
\text { ESTATIS } \\
\text { TICOS }\end{array}$} & \multicolumn{3}{|c|}{ VAZÃO $(1 / h)$} & \multicolumn{3}{|c|}{ VAZAOO ESPEC. $(1 / \mathrm{h}$} & \multirow{2}{*}{\multicolumn{3}{|c|}{$\frac{\text { R E S I D U O }}{\text { EGIAO OCTDENTAL }}$}} & \multicolumn{3}{|c|}{$(\mathrm{mg} / 1)$} \\
\hline & \multirow{2}{*}{$\begin{array}{l}\text { R.G. } \\
\text { NORTE }\end{array}$} & \multirow{2}{*}{$\begin{array}{r}\text { PARA } \\
\text { IBA }\end{array}$} & \multirow{2}{*}{ TOTAL } & \multirow{2}{*}{$\begin{array}{l}\text { R.G. } \\
\text { NORTE }\end{array}$} & \multirow{2}{*}{$\begin{array}{r}\text { PARA } \\
\text { IBA }\end{array}$} & \multirow{2}{*}{ TOTAL } & & & & \multicolumn{3}{|c|}{ REGIÃO ORIENTAL } \\
\hline & & & & & & & $\mathrm{RN}$ & $\mathrm{PB}$ & TOTAL & $\mathrm{RN}$ & $\mathrm{PB}$ & TOTAL \\
\hline Minima & 120 & 59 & 59 & 0,7 & 8 & 0,7 & 138,8 & 125,08 & 125,8 & 534,8 & 355,0 & 355,0 \\
\hline Mäxima & 36.000 & 13.090 & 36.000 & 17.308 & 3.801 & 17.308 & $14.945,6$ & $11.315,00$ & $14.945,6$ & $31.125,0$ & $17.985,0$ & $31: 125,0$ \\
\hline Mẻdia & 3.878 & 2.193 & 3.077 & 657 & 345 & 507 & $1.731,6$ & $1.211,46$ & $1.436,2$ & $6.208,6$ & $4.680,17$ & $5.581,7$ \\
\hline D.Padrão & 4.324 & 2.353 & - & 1.714 & 642 & - & $2.018,5$ & $1.550,47$ & - & $5.340,4$ & $3.958,3$ & - \\
\hline Coef.Var. $(\%)$ & 111,5 & 107,3 & - & 260,8 & 185,7 & - & 116,6 & 127,98 & - & 86,0 & 84,6 & - \\
\hline Niamostras & 443 & 400 & 843 & 425 & 396 & 821 & 191 & 251 & 442 & 197 & 137 & 334 \\
\hline
\end{tabular}


QUADRO 6.2 - DISTRIBUIÇAO DOS POÇOS SEGUNDO TIPOS LITOLÖGICOS

\begin{tabular}{|c|c|c|c|c|c|c|}
\hline \multirow[b]{2}{*}{ ROCHA } & \multicolumn{2}{|c|}{ RIO G.DO NORTE } & \multicolumn{2}{|c|}{ PARAIBA } & \multicolumn{2}{|c|}{ TOTAL } \\
\hline & $\begin{array}{l}\text { NQ DE } \\
\text { POÇOS }\end{array}$ & $\begin{array}{c}\% \text { DO } \\
\text { ESTADO }\end{array}$ & $\begin{array}{l}\text { NO DE } \\
\text { POÇOS }\end{array}$ & $\begin{array}{c}\because \text { DO } \\
\text { ESTADO }\end{array}$ & $\begin{array}{l}\text { N: DE } \\
\text { POÇOS }\end{array}$ & $\begin{array}{l}\because \mathrm{DO} \\
\text { TOTAL }\end{array}$ \\
\hline Gnaisse & 301 & 67,9 & 224 & 56,0 & 525 & 62,3 \\
\hline Micaxisto & 53 & 12,0 & 51 & 12,8 & 104 & 12,3 \\
\hline Granito & 64 & 14,4 & 45 & 11,3 & 109 & 12,9 \\
\hline Migmatito & 14 & 3,2 & 27 & 6,8 & 41 & 4,9 \\
\hline Filito & - & - & 39 & 9,7 & 39 & 4,6 \\
\hline Quartzito & 9 & 2,0 & 7 & 1,7 & 16 & 1,9 \\
\hline Outras rochas & 2 & 0,5 & 7 & 1,7 & 9 & 1,1 \\
\hline TOTAL & 443 & & 400 & & 843 & \\
\hline
\end{tabular}


10 ctones, depositados por processos variados, principalmente por meio fluvial - aluviōes, ou gravitativos - coluviőes. A distinção desses tipos de depósito; se torna impossível de vez que nem sempre consta da ficha do poço, figurando apenas a constituição granulomëtrica.

A classificação granulomëtrica $\vec{e}$ um dado importante para se aquilatar a permeabilidade do manto e verificar se o mesmo atua favorâvel ou desfavoravelmente à recarga do aquífero fissu ral que the è sotoposto. Essa classificação não é muito rïgida, pois foi executada na base da observação visual do tëcnico, sem relização de um peneiramento para a devida quantificaçāo percentual das diversas frações granulomêtricas. Em função dessa meto dologia empîrica, as descrições ficam bastante diversificadas, podendo-se citar, por exemplo, que a equipe tëcnica da CDM-RN a dota apenas as frações areia e argila, classificando ainda as misturas da areia argilosa e argila arenosa em função da fração dominante ; enquanto isso a equipe do CDRM-PB, adota alëm desses quatro tipos, os tipos areia siltosa, silte arenoso e silte argi loso.

No Quadro 6.3, aparecem os quantitativos e respectivos a percentuais dessas frações granulomëtricas, análises por Estado e no total da ärea.

A fração psamítica fica em torno de $1 / 4$, contra $3 / 4$ de pelitos e misturas variadas de mais baixa permeabilidade, o que caracteriza um meio pouco favorave1 à recarga do aquifero fissu ral sotoposto.

A espessura desse manto é variável, um pouco superior no Estado do R.G. do Norte, onde chega a atingir 19, 0m ; na Paraíba - mäximo atingido foi de $12,0 \mathrm{~m}$, sendo as mêdias nos dois Estados de $3,85 \mathrm{~m}$ e 2,42m respectivamente, Na Paraíba 55 poços $(13,7 \%)$ não possuiam qualquer manto de cobertura, enquanto no R.G. do Norte nenhum poço foi perfurado inteiramente na rocha. 
QUADRO 6.3 - DISTRIBUIÇAO DOS POÇOS POR TIPOS DE COBERTURA

\begin{tabular}{|c|c|c|c|c|c|c|}
\hline \multirow{2}{*}{$\begin{array}{c}\text { FRAÇAO GRANULQ } \\
\text { METRICA }\end{array}$} & \multicolumn{2}{|c|}{ R.G.DO NORTE } & \multicolumn{2}{|c|}{ PARAIBA } & \multicolumn{2}{|c|}{ TOTAL } \\
\hline & $\begin{array}{l}\text { N` DE } \\
\text { POÇOS }\end{array}$ & $\begin{array}{c}: \text { DO } \\
\text { ESTADO }\end{array}$ & $\begin{array}{l}\text { No DE } \\
\text { POÇOS }\end{array}$ & $\begin{array}{c}\% \text { DO } \\
\text { ESTADO }\end{array}$ & $\begin{array}{l}\text { No DE } \\
\text { POÇOS }\end{array}$ & $\begin{array}{l}: \text { DO } \\
\text { TOTAI }\end{array}$ \\
\hline Areias & 139 & 31,9 & 59 & 17,7 & 198 & 25,7 \\
\hline Areias argilosas & 176 & 40,5 & 75 & 22,4 & 251 & 32,6 \\
\hline Argilas & 48 & 11,0 & 43 & 12,9 & 91 & 11,8 \\
\hline Argilas arenosas & 72 & 16,6 & 53 & 15,9 & 125 & 16,2 \\
\hline Siltes arenosos & - & - & 75 & 22,4 & 75 & 9,8 \\
\hline Siltes argilosos & - & - & 29 & 8,7 & 29 & 3,8 \\
\hline TOTAL & 435 & & 334 & & 769 & \\
\hline
\end{tabular}


6.3.3. FRATURAS

Dois aspectos estruturais relativos a fraturas säo anotados no Cadastro: um, relativo às fraturas aflorantes na superfücie, que serviram (ou não) como critêrio para a locação do poço; cutro, relacionado às fraturas em profundidade, interceptadas durante a perfuração do poço.

Quanto as primeiras, foi efetuado um estudo para classificação do tipo de fratura em função da geometria (relaçäo com os planos de xistosidade ou lineação da rocha) e da gênese ( esforço que provocou a deformação).

Do total de poços amostrados - 246 - a distribuição do nümero de poços relacionados aos tipos de fraturas estudadas foi a que se segue :

- Fratura transversal tracional - 58 poços $(23,9 \%)$

- " angular de cisalhamento - $60 "$ " $(24,3 \%)$

- "longitudinal tracional - $10 "$ " $(4,0 \%)$

- " " de cisalhamento- $12 "$ " $" 4,8 \%)$

" " indefinida $" 19 "$ " $(7,7 \%)$

- Sem fratura (na superficie) - 50 " $(20,2 \%)$

No que conccrne às fraturas interceptadas pelos poços, cabe ressaltar a diferença na quantificação apresentada pelos po ços do R.G. do Norte e da Paraíba. E que na CDM-RN eram registra dos nas fichas dos poços todas as fraturas encontradas, enquanto na CDRM-PB, apenas a(s) melhor(es) e produtiva(s) era(m) regis$\operatorname{trada}(s)$,

\subsubsection{RELEVO/HIDROGRAFTA}

A associação relevo/hidrografia foi estabelecida, tendo em vista a intensa ondulação da superfície topogräfica, com contínuos vales e interfiūvios, sendo portanto constante a correlação morfolögica com a drenagem superficial.

Foram consideradas 3 (três) situaçōes distintas do rele vo, associadas à drenagem superficial, a saber : 
a) fundo do vale, ou talvegue

b) encosta do vale, ou vertente

c) topo de elevações, ou interflüvios.

Do total de poços amostrados - 254 - a distribuição do nümero de poços perfurados em cada uma dessas distintas situa ções morfo-hidrogräficas, foi:

$$
\begin{aligned}
& \text { - Poços no talvegue }-172(67,7 \%) \\
& \text { - " na encosta - } 51(20,1 \%) \\
& \text { - } \quad \text { nas elevações }-31(12,2 \%)
\end{aligned}
$$

6.3.5. RESTDUO SECO

o estudo hidroquímico, realizado, foi baseado unicamente no resîduo seco ou sólidos totais dissolvidos, no sentido de for necer uma visão espacial dos diferentes comportamentos de qualídade das äguas.

Não objetiva o presente trabalho, uma pesquisa hidroquî mica, nem tão pouco a classificação das äguas para os diversos fins (consumo humano, pecuärio, irrigação), pois iria desviir tuar os propösitos a que se destina.

Os valores de resíduo seco, permitiram estabelecer duas regiões distintas, a oriental e a ocidental, jä mencionadas nos tratamentos morfo-hidrogräficos discutidos atrăs.

Assim, no Quadro 6.1 os valores médios e os parâme :tros de dispersão analisados foram apresentados separadamente pa ra cada Estado, por região mencionada.

Apesar de nem todos os poços possuirem anälise química, a amostragem pode ser considerada muito boa, de vez que abrangeu $91,6 \%$ da população de poços disponíve1 ao estudo.

No Estado do R.G. do Norte o resîduo seco médio, na regi ão ocidental, representou apenas $27,9 \%$ da mêdia do resíduo seco da região oriental e na Paraíba, essa mesma relação foi muito próxima, com o valor de $25,9 \%$. No geral, o resî́duo seco da região ocidental representa apenas $27 \%$ do resîduo seco da região orienta1, ou seja, na região oriental as águas possuem quase qua- 
tro vezes, o total de sais apresentados na região ocidental.

Embora com mais elevadas taxas de salinização, a dis persão de valores ê menor na região oriental, com cerca de $85 \%$, do que na região ocidental, onde gira em torno de $120 \%$.

A frequência com que ocorrem os diferentes valores de re síduo seco ê mostrada no Quadro 6.4 . onde aparece uma subdivi são de valores de R.S. segundo a classificação de Schoeller \& Begal off:

$$
\begin{aligned}
& \text { R.S. } \leqslant 1.000 \text { - Agua de potabilidade boa a passável } \\
& 1.000<\mathrm{R} . \mathrm{S} . \leqslant 2.000-. " \text { " " "medrocre. }
\end{aligned}
$$

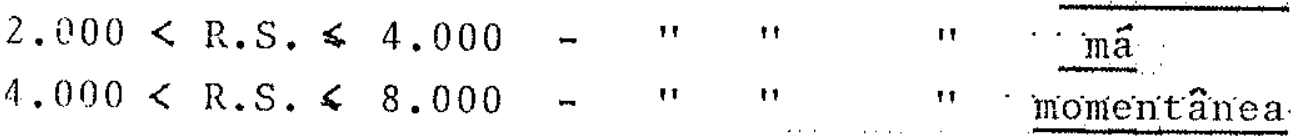

$$
\begin{aligned}
& \text { R.S. }>8.000-" \text { nẫo potave1. }
\end{aligned}
$$

De princípio, constata-sc uma fundamental diferença ent tre as âguas da região oriental e as da região ocidental : nas primeiras, $22,5 \%$ das âguas possuem potabilidade boa a mediocre, enquanto $77,4 \%$ são de potabilidade mä atë não potäveis (estas perfazendo 20\%); nas segundas ocorre o inverso, ou $81,2 \%$ dos $t \underline{i}$ pos boa a passâvel e apenas $18,8 \%$ de mä a näo potäveis (estas com somente $2,2 \%$ ).

Na comparação entre os dois Estados, apesar de não ser grande a diferença, nota-se que as äguas na Paraíba são ligeiramente melhores, sobretudo na região ocidental, em que 70,5: possuem menos de $1.000 \mathrm{mg} / 1$ (potabilidade boa a passäve1) contra $45 \%$ da mesma categoria para 0 R.G. do Norte.

6.3.6. PROFUNDIDADE DOS POÇOS

Todos os 843 poços cadastrados, possuem registro da profundidade, que apresenta em toda a ârea, o mais baixo îndice de dispersão dentre todos os dados estatisticamente analisados.

Com efeito, o coeficiente de variação para a profundidade dos poços no R.G. do Norte foi de apenas $18,9 \%$, sendo menor a inda na paraíba com $14,59 \%$. 
QUADRO 6.4 - FAIXAS DE VARIAÇÃO DO RESIDUO SECO

I) REGIAO ORIENTAL

\begin{tabular}{|c|c|c|c|c|c|c|}
\hline \multirow{2}{*}{ FAIXAS DE R.S. } & \multicolumn{2}{|c|}{ R.G.NORTE } & \multicolumn{2}{|c|}{ PARAIBA } & \multicolumn{2}{|c|}{ TOTAL } \\
\hline & $N^{8}$ & $\frac{\circ}{0}$ & $\mathrm{~N}^{8}$ & $\frac{\circ}{0}$ & $N^{9}$ & $\frac{0}{0}$ \\
\hline R.S. $<1000$ & 17 & 8,6 & 12 & 8,8 & 29 & 8,7 \\
\hline $1000<$ R.S. $<2000$ & 24 & 12,2 & 22 & 16,0 & 46 & 13,8 \\
\hline $2000<$ R.S. $<4000$ & 45 & 22,8 & 47 & 34,3 & 92 & 27,5 \\
\hline $4000<$ R.S. $<8000$ & 68 & 34,5 & 32 & 23,4 & 100 & 29,9 \\
\hline R.S.>8000 & 43 & 21,8 & 24 & 17,5 & 67 & 20,0 \\
\hline Nide amostras & \multicolumn{2}{|l|}{197} & \multicolumn{2}{|l|}{137} & \multicolumn{2}{|l|}{334} \\
\hline
\end{tabular}

II) REGIAO OCIDENTAL

\begin{tabular}{|c|c|c|c|c|c|c|}
\hline \multirow{2}{*}{ FAIXAS DE R.S. } & \multicolumn{2}{|c|}{ R.G.NORTE } & \multicolumn{2}{|c|}{ PARAIBA } & \multicolumn{2}{|c|}{ TOTAL } \\
\hline & $\mathrm{N}^{\circ}$ & $\frac{0}{0}$ & $\mathrm{~N}:$ & $\frac{0}{6}$ & $N^{\circ}$ & $\frac{0}{0}$ \\
\hline R.S. $<1000$ & 86 & 45,0 & 177 & 70,5 & 263 & 59,5 \\
\hline $1000<$ R.S. $<2000$ & 56 & 29,3 & 40 & 15,9 & 96 & 21,7 \\
\hline $2000<$ R.S. $<4000$ & 32 & 16,8 & 20 & 8,0 & 52 & 11,8 \\
\hline $4000<$ R.S. $<8000$ & 11 & 5,8 & 10 & 4,0 & 21 & 4,8 \\
\hline R.S.> 8000 & 6 & 3,1 & 4 & 1,6 & 10 & 2,2 \\
\hline$N^{\circ}$ de amostras & 191 & & 251 & & 442 & \\
\hline
\end{tabular}

III) TOTAL DA AREA

\begin{tabular}{|r|r|r|}
\hline & $N^{\circ}$ & $\frac{0^{\circ}}{}$ \\
\hline R.S. $<1000$ & 292 & 37,6 \\
$1000<$ R.S. $<2000$ & 142 & 18,3 \\
$2000<$ R.S. $<4000$ & 144 & 18,6 \\
$4000<$ R.S. $<8000$ & 121 & 15,6 \\
R.S.>8000 & 77 & 9,9 \\
\hline$N^{9}$ de amostras & 776 & \\
\hline
\end{tabular}


Os poços, de um modo geral, säo mais profundos no R.G.do Norte, onde a CDM estabelece um valor padrão de $60 \mathrm{~m}$. Com efeito, $52,8 \%$ dos poços perfurados por aquela empresa tiveram a exata profundidade de $60 \mathrm{~m} ; 7,9 \%$ ultrapassaram essa profundidade, at $\vec{e}$ o limite de $101,0 \mathrm{~m}$ e $39,3 \%$ ficaram com profundidades menores,variando desde 23,0 atê os $59,0 \mathrm{~m}$. Da $\vec{i}$ a média de $54,57 \mathrm{~m}$ apresentada para esse Estado.

Na Paraíba o patamar de limitação de profundidade fica nos $50 \mathrm{~m}$, perfazendo $46^{\circ}$ dos poços perfurados pela CDRM. Grande parte dos poços, entretanto, fica com a profundidade de $40 \mathrm{~m}$, per fazendo $28,5 \%$ do total perfurado. Apenas $8,2 \%$ excedem a profund dade de $50 \mathrm{~m}$ atê o máximo de $78 \mathrm{~m}$, enquanto os $17,3 \%$ restantes sí tuam-se a profundidades desde $20 \mathrm{~m}$ até os $49 \mathrm{~m}$ (excluindo os $40 \mathrm{~m}$ ). A mêdia geral da profundidade dos 400 poços, perfurados pela CD $\mathrm{RM}$, ficou em $46,06 \mathrm{~m}$.

De um modo geral, para toda a ärea de estudo, a mëdia de profundidade dos poços ficou em torno dos $50,0 \mathrm{~m}$.

\subsubsection{NTVEL ESTATTCO}

As äguas da região apresentam profundidades muito pequenas, não diferindo muito de um Estado para outro, apesar do elevado coeficiente de variação, superior a $90 \%$ no R.G.do Norte e a $70 \%$ na Paraíba.

A mẻdia geral na região, fica pröxima aos $5,0 \mathrm{~m}$, com 1 imi tes superiores de $31,0 \mathrm{~m}$ no $\mathrm{RN}$ e $24,2 \mathrm{~m}$ na paraíba; os 1 imites mínimos, representam em ambos os Estados, vazões surgentes, com a1turas de superfícies piezomëtricas mäximas de $+3,8 \mathrm{~m}$ no R.G. do Norte e $+0,8 \mathrm{~m}$ na Paraíba.

A amostragem atingiu a $97,7 \%$ da população total do estudo. 
Quase o mesmo nümero de amostras tem registrado o nível dinâmico para a vazão testada, com valores pouco variäveis em torno da mëdia, que atingiu a $23 \mathrm{~m}$ no R.G.do Norte e a $16 \mathrm{~m}$ na $\mathrm{Pa}-$ raỉba. A média geral, em torno dos $20 \mathrm{~m}$, representou um rebaixamento médio do nível das äguas ao final do ensaio do bombeamento da ordem de $15 \mathrm{~m}$.

Se bem que o nĩvel dinâmico não constitua um parâmetro de correlação regional (como o nảvel estático), de vez que depen de da capacidade do equipamento de bombeamento utilizado no teste, o seu conhecimento ë imprescindível para a avaliação da vazão específica, principal parâmetro de correlação, entre os po ços.

\subsubsection{VAZAO}

A vazão de um poço não constitui um parâmetro muito representativo e não deve ser utilizado em correlações ou trata mentos estatîsticos entre distintas regiões, tipos de rochas ou qualquer outra variáve1 considerada.

De um certo modo, todavia, o seu valor médio guarda uma certa correlação com a vazão específica, como pode ser visto no exemplo das mêdias calculadas para cada um desses parâmetros. Com efeito, a relação entre a vazão mëdia do teste dos 400 poços da Paraíba, para a vazão mẻdia de teste dos 443 poços do R.G. do Norte, foi de $56,5 \%$, enquanto a mesma relação para a vazão específica, acusou o valor de $52,6 \%$.

Observa-se portanto, que os poços do R.G. do Norte apresentam vazões consideravelmente superiores (quase o dobro) às dos poços da Paraíba e a média geral para os dois Estados situase em torno dos $3.0001 / \mathrm{h}$ que representa, conforme estudos anter $\underline{\underline{i}}$ ormente executados, a média geral para todo o nordeste.

Deve-se considerar que os cälculos estatísticos(mëdia, , desvio padrão e coeficiente de variação), apresentados no Quadro 
6.1 , levaram em conta toda a população de dados de poços(843) da região. o coeficiente de variação revela uma grande dispersão de valores em torno da mëdia, superando os $100 \%$ em ambos os Esta dos; a diferença entre o mínimo e o mäximo valores de vazão, am tingiu a 300 vezes, no R.G. do Norte e 220 vezes na Paraíba.

\section{3 .10 . VAZAO ESPECIFICA}

A relação entre a vazão testáda e o respectivo rebaixamento constitui a vazão-especifica, o parâmetro menos falho na correlação da potencialidade de poços.

Alguns autores têm utilizado a relação vazão específica por espessura saturada $[(1 / /) / m] / m$ para caracterizar a produtivi dade de um poço, como por exemplo SIDIQQUI \& PARIZEK (1971) que adotaram esse parâmetro, com a designação mesmo de produtivida . de do poço, para aquíferos cárstico-fissurais, A nível nacional, esse parâmetro jâ foi utilizado na região nordeste, pela SUDE NE (1978) que dividiu a vazão espeḉfica pela profundidade ütil do poço, representada pela djferença entre a profundidade da $\vec{u} 1-$ tima entrada dâgua e do nîvel estätico do poço. Posteriormente, MENDES (1980) utilizou um parâmetro semelhante, da mesma dimensão $\mathrm{L}^{3} \mathrm{~T}^{-1} \mathrm{~L}^{-2}$, porẻm a vazão específica era dividida pela profundidade total do poço. Uma outra proposta foi apresentada por HONYK (1979), a que denominou de produção potencia1 do poço- PPP e que relacionava a vazão especifica com o rebaixamento do nível estâtico, a espessura estätica saturada, a profundidade efetiva do poço e o coeficiente exponencial característico de cada tipo de rocha.

Quanto a metodologia adotada pela SUDENE, op.cit. e MENDES op.cit. somos inteiramente conträrios, visto que em aquí fero fissural, a relação da vazão com a profundidade é direta atë determinada profundidade, um pouco acima da entrada de àgua principal; a partir daí a relação passa a ser constante durante um certo intervalo (de rebaixamento) e passa depois a ser inver sa. Somente em aquífero poroso, aproximadamente homogêneo e isotrỏpico, essa relação poderìa ser empregada e assim mesmo, para 
poços totalmente penetrantes. O pröprio Albuquerque em sua Dissertação de Mestrado (ALBUQUERQUE, 1984) passou a utilizar a va zão especifica (o mesmo técnico que elaborou o estudo da SUDENE). A proposta de Honyk para a sua produção potencial é fa1ha, ao nosso ver, em função, sobretudo, do coeficiente exponencial, adotado empiricamente para cada tipo de rocha. E possível que no futuro, a partir de pesquisas mais aprofundadas, esse parâmetro venha a ser melhorado nas suas falhas principais.

$\mathrm{Na}$ região estudada, as vazões especificas foram muito va riadas, com um mînimo de $0,7(1 / h) / m$ no R.G. do Norte e mäximo de $17.308(\mathrm{l} / \mathrm{h} / \mathrm{m}$, ou seja, 24.725 vezes o minimo assinalado; na Paraî́ba essa variação foi menor, com um mînimo de $8(1 / \mathrm{h}) / \mathrm{m}$ e mäximo de $3.801(1 / \mathrm{h} / \mathrm{m}$ (475 vezes). Em função dessa variação o coeficien te de variação foi de $260,84 \%$ no R.G.do Norte, para uma vazão es pecífica mẻdia de $657,1(1 / \mathrm{h}) / \mathrm{m}$ e 185,7 g na paraíba, para uma média de vazão especifica de $345,7(1 / \mathrm{h}) / \mathrm{m}$. Esses valores mẻdios es tão muito exagerados, tendo sido impulsionados para cima em função das vazões anômalas acima dos $1.000(1 / \mathrm{h}) / \mathrm{m}$.

No Quadro 6.5, ê realizada uma anälise da frequência de vazão específica por região em cada Estado. De um modo geral, cer ca de $40 \%$ dos poços, em termos médios gerais, apresentam vazão específica abaixo de $100(1 / \mathrm{h} / \mathrm{m} ; 50 \%$ ficam entre $100 \mathrm{e} 1.000(\mathrm{l} / \mathrm{h})$ $/ \mathrm{m}$ e apenas $10 \%$ ultrapassam os $1.000(\mathrm{l} / \mathrm{h} / \mathrm{m}$. A anä1ise por Estado mostra que na paraîba cerca de $80 \%$ na região oriental e $90 \%$ na ocidenta1, apresentam vazões específicas inferiores a $500(1 / \mathrm{h} / \mathrm{m}$; no R.G.do Norte esses percentuais säo respectivamente de $70 \%$ e $80 \%$ nas duas regiões. Por regiäo, verifica-se que na região oriental $70 \%$ dos poços apresentam vazöes especificas inferiores a $500(1 / \mathrm{h}) / \mathrm{m}$ contra $80 \%$ para a região ocidental. Daí concluirmse que a melhor ärea ê a região oriental do Estado do Rio Grande do Norte. 
QUADRO 6.5. FAIXAS DE VARTAÇÃO DA VAZÃO ESPECIFICA

I) REGIXO ORTENTAL

\begin{tabular}{|c|c|c|c|c|c|c|}
\hline \multirow{2}{*}{ FAIXAS DE Q/s } & \multicolumn{2}{|c|}{ R.G.NORTE } & \multicolumn{2}{|c|}{ PARAIBA } & \multicolumn{2}{|c|}{ TOTAL } \\
\hline & $\mathrm{N}^{8}$ & $\frac{0}{0}$ & $N^{9}$ & $\%$ & N: & $\because$ \\
\hline$Q / s<100$ & 68 & 31,8 & 48 & 33,8 & 116 & 32,6 \\
\hline $100<Q / s<500$ & 78 & 36,4 & 62 & 43,7 & 140 & 39,3 \\
\hline $500<Q / s<1000$ & 36 & 16,8 & 20 & 14,1 & 56 & 15,7 \\
\hline $\mathrm{Q} / \mathrm{s}>1000$ & 32 & 14,9 & 12 & 8,4 & 44 & 12,4 \\
\hline $\begin{array}{l}\text { Vaz.Esp.Média } \\
(1 / \mathrm{h}) / \mathrm{m}\end{array}$ & \multicolumn{2}{|c|}{775,25} & \multicolumn{2}{|c|}{401,52} & \multicolumn{2}{|c|}{626,18} \\
\hline
\end{tabular}

IT) REGTATO OCTDENTAL

\begin{tabular}{|c|c|c|c|c|c|c|}
\hline \multirow{2}{*}{ FAIXAS DE Q/s } & \multicolumn{2}{|c|}{ R.G.NORTE } & \multicolumn{2}{|c|}{ PARAIBA } & \multicolumn{2}{|c|}{ TOTAL } \\
\hline & Ni & $\%$ & N? & $\stackrel{\circ}{0}$ & $\mathrm{~N}^{8}$ & $\stackrel{\circ}{0}$ \\
\hline $\mathrm{Q} / \mathrm{s}<100$ & 90 & 42,4 & 129 & 50,6 & 219 & 46,9 \\
\hline $100<\mathrm{Q} / \mathrm{s}<500$ & 73 & 34,4 & 96 & 37,6 & 169 & 36,2 \\
\hline $500<Q / S<1000$ & 22 & 10,4 & 13 & 5,1 & 35 & 7,5 \\
\hline$Q / s>1000$ & 27 & 12,7 & 17 & 6,7 & 44 & 9,4 \\
\hline $\begin{array}{l}\text { Vaz.Esp.Mëdia } \\
(1 / \mathrm{h}) / \mathrm{m} \\
\end{array}$ & \multicolumn{2}{|c|}{525,93} & \multicolumn{2}{|c|}{315,57} & \multicolumn{2}{|c|}{411,06} \\
\hline
\end{tabular}

III) TO'TAL DA AREA

\begin{tabular}{|c|c|c|c|}
\hline & $N^{\circ}$ & $\%$ & $\%$ \\
\hline$Q / s<100$ & 335 & 40,7 & 40,7 \\
\hline $100<Q / s<500$ & 309 & 37,5 & \\
\hline $500<Q / S<1000$ & 91 & 11,0 & \\
\hline$Q / S>1000$ & 88 & 10,7 & 10,7 \\
\hline $\begin{array}{l}\text { Vaz.Esp.Mëdia } \\
(1 / \mathrm{h}) / \mathrm{m}\end{array}$ & \multicolumn{3}{|c|}{504,11} \\
\hline
\end{tabular}


CAPITULO No 7

REILACIONAMENTO ENTTE IPARAMETIROS IDE POCOS HE IFTORAS ATUANTES 


\subsection{INTRODUCAO}

A principal atividade desenvolvida na pesquisa, correspon deu tha busca de relacionamento entre os diversos parâmetros do po ço, do aquífero, do meio externo e da prôpria âgua, quanto ’a sua qualidade. tentadas:

De maneira esquemätica, foram as seguintes as correlaçöes

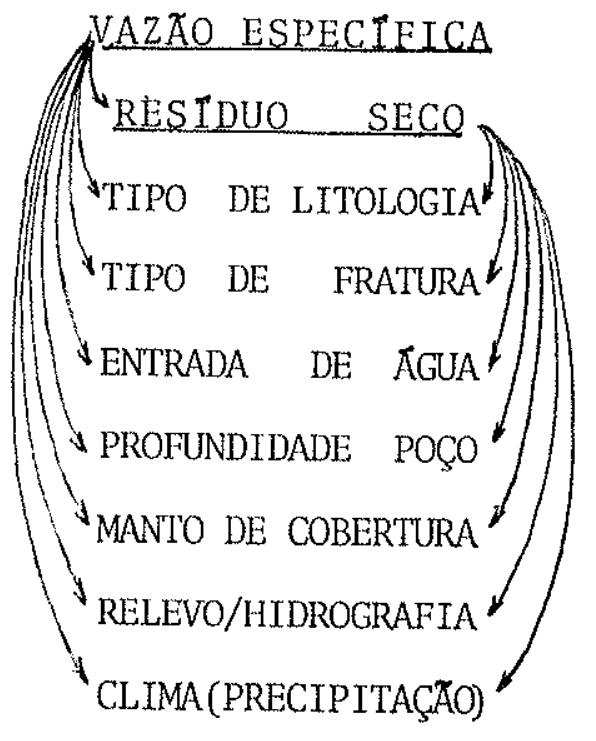

Nos capítulos seguintes serão analisadas cada uma dessas relações.

7.2. RELACOES ENTRE OS PARAMETROS DO POÇO E FATORES INTRINSECOS E EXTRTNSECOS.

7.2.1. RELAÇÃO VAZÃO ESPECTFICA X REST́DUO SECO

Conforme $j \vec{a}$ mencionado na primeira parte (teôrica) deste trabalho, em função de maiores volumes infiltrados e armazenados (que vão proporcionar melhores vazões), maior serā a renovação das ăguas e por conseguinte menores seräo os îndices de salinização.. 
Assim, era esperado encontrar-se uma boa correlação entre esses dois parâmetros, que representam o binômio quantidade-quai dade da ägua subterrânea. Essa relaçäo deveria ser inversa, pois a medida que aumenta o volume, deve diminuir a salinidade.

Foram plotados em gräficos mono-log, de resíduo seco $x$ va zão específica (escala $10 \mathrm{~g}$ ) os dados dos poços da região oriental do Estado do R.G. do Norte (Fig.7.1) e da região ocidental do $R$. G. do Norte (Fig.7.2.).

No primeiro gráfico (Fig.7.1) os dados se dispuzeram numa autêntica "nuvem de pontos", sem qualquer relação entre os dois parâmetros utilizados, nẹ mesmo, demonstrar alguma "tendência"de. correlação. A grande quantidade de pontos, com valores extrema mente variâveis, tanto de vazão específica (desde 0,7 atê 17.308 $\left(1 / \mathrm{h} \gamma_{\mathrm{m}}\right.$ ) como de residuo seco (desde 535 ate $31.125 \mathrm{mg} / 1$ ) aliados a interferência de outros fatores, sobretudo a infiltração de aguas salinizadas dos maiores cursos d'ägua forgm responsāveis por essa ausência completa de correlação. Com efeito, nessa região, predominam os rios com äguas salinizadas, como o Cearä-Mirim, Potengi e parte do Jacu, que provocam infiltração em rochas e, mesmo nas mais fraturadas e com maior vazão específica, vão deteriorar a qualidade do aquîfero. Essa è a razão pela qual, dos 31 poços com vazões especificas superiores a $1.000(1 / \mathrm{h} / \mathrm{m}$, mais da metade $(54,8 \%)$, possuem resíduo seco superior a $4.000 \mathrm{mg} / 1$, e apenas $12 \%$, possuem R.S.< $1.000 \mathrm{mg} / 1$ (äguas potäveis). Convêm lembrar, que, nessa região, o resíduo sëco mëdio nos poços foi de $6.200 \mathrm{mg} / 1$.

No segundo gräfico (Fig. .2) a salinidade $\ddot{e}$ muito baixa ( mêdia de $1.700 \mathrm{mg} / 1$ devida a alguns valores anômalos) e predomi nam os valores abaixo de $1.500 \mathrm{mg} / 1$. Foi tentada uma correlação matemätica usando o mëtodo de mínimos quadrados em programa compu tadorizado, em que diferentes gráficos ( X, Y; $\log X, \log Y ; \operatorname{logX}$, $Y, X, \log Y)$ eram analisados e distintas equaçöes matemäticas a partir dos coeficientes a $e^{\prime} \underline{b}$ eram tambëm trabalhados. Infelizmen te não se conseguiu estabelecer nenhuma correlação matemática, pois os indices de correlação para cada tipo de gräfico variaram desde o valor mäximo de-0,185 atê o mínimo de $-0,0056$, o que significa, a ausência de qualquer correlação. Os valores negativos revelam entretanto uma incipiente relação inversa (Ver Quadro 7.1) Apesar dos baixissimos índices de correlação registrados, certamente provocados pelos dados anômalos, extremamente elevados, 
FIG. 7.1

RELAÇĀO R. S. X VAZĀO ESPECÍFICA

(REGIĀO ORIENTAL DO RIO G.NORTE)

R. $s(m g / l)$

$4 \quad \rightarrow \quad \pi \quad 4000$

$12.000 \div$

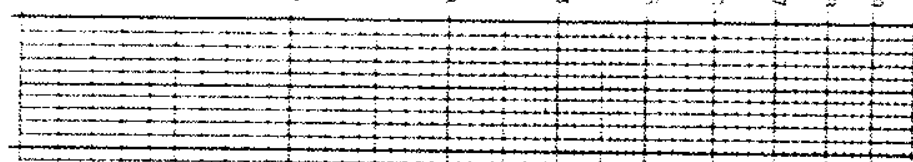

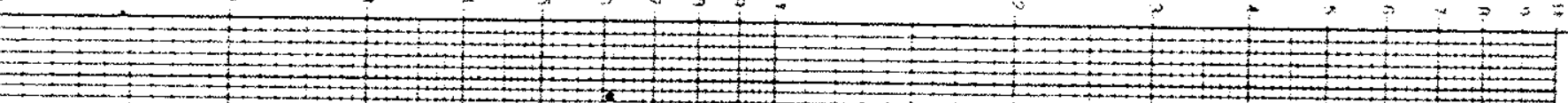

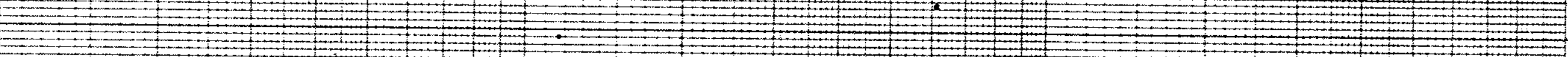

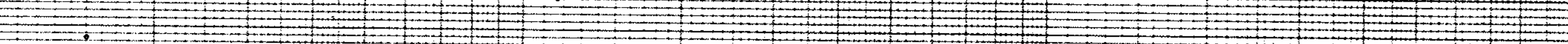

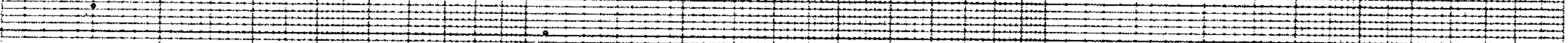

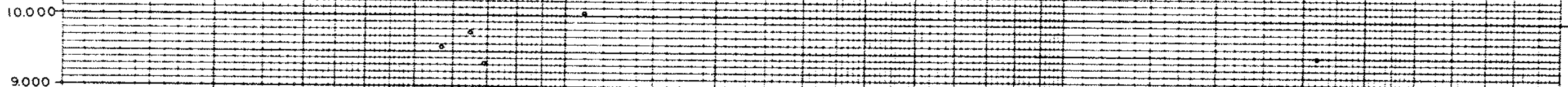

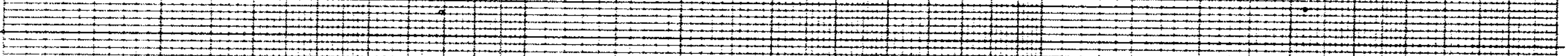

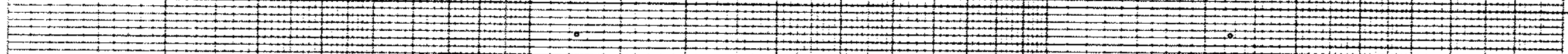

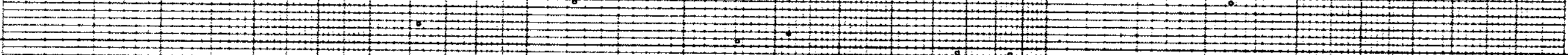

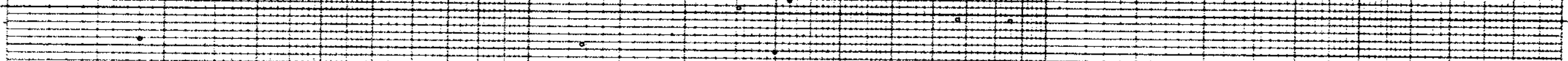

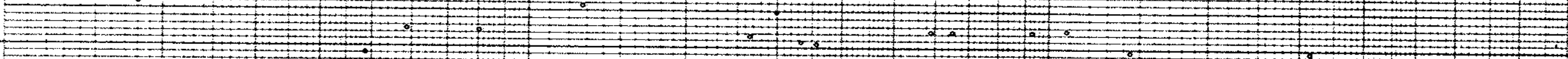

2000

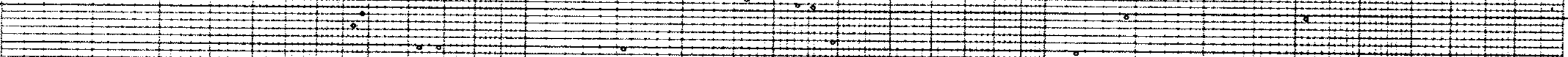

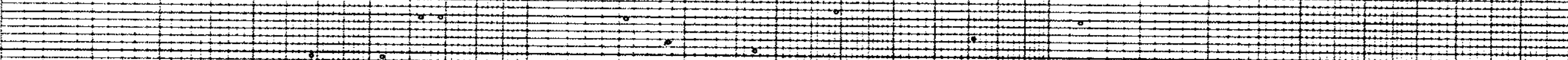

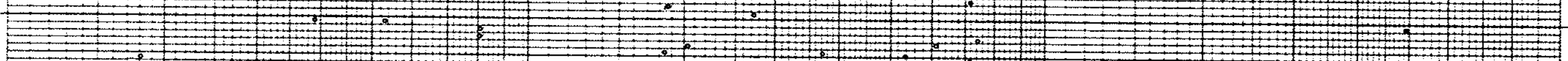

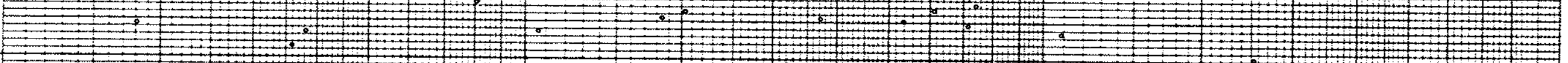

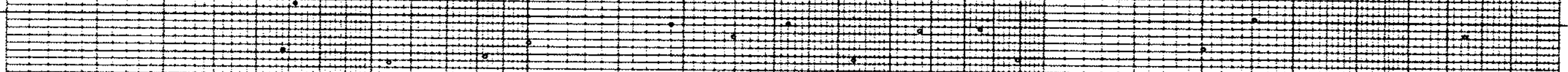

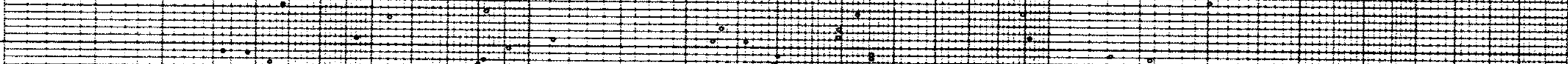

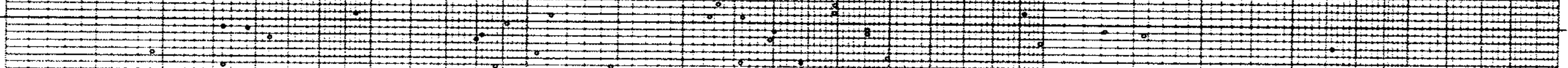

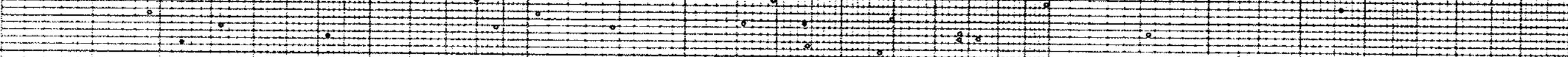

3.000

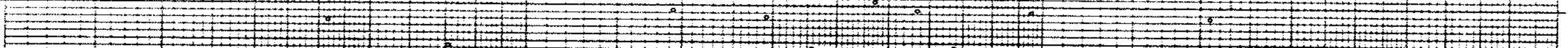

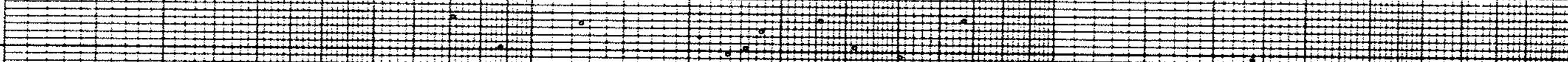

1000

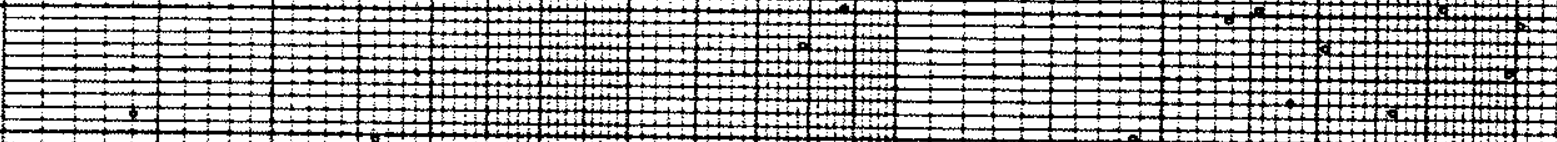


FIG.7.2 - RELAÇĀO Q/SW X R.S.

- REgIĀO OCIDENTALI BACIA DO RIO

PIRANHAS) RIO G. DO NORTE

$:$ :

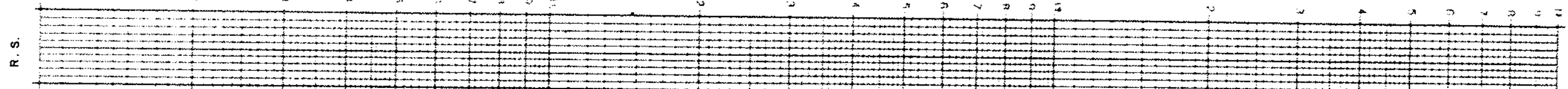

\section{PIRANHAS) RIO G. DO NORTE}

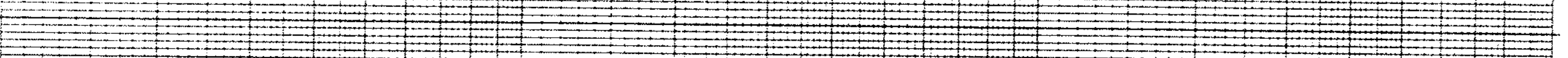

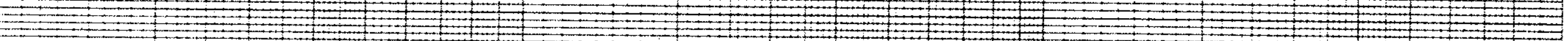

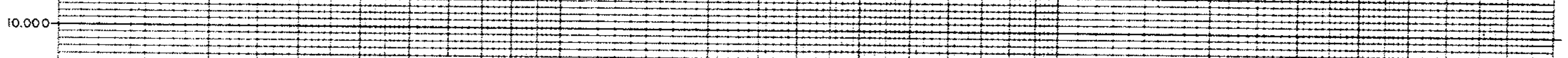

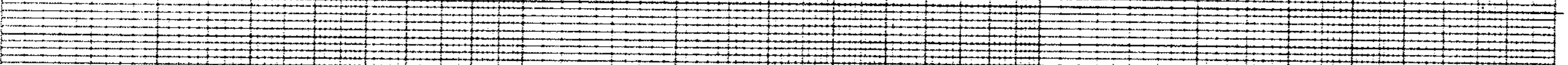

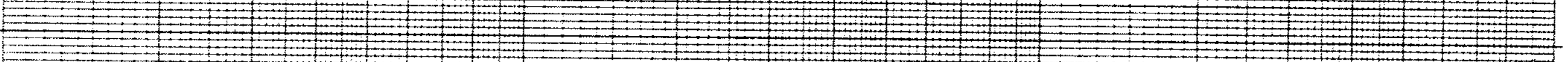

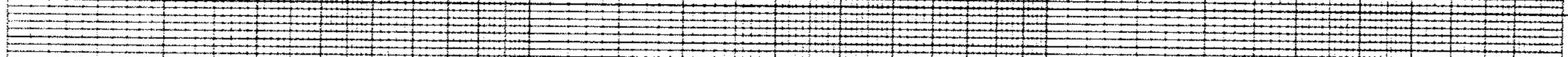

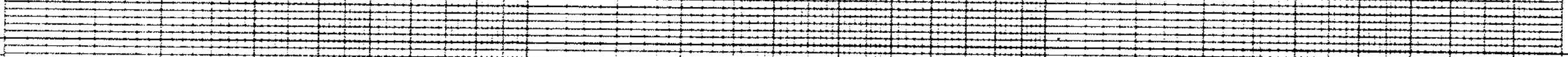

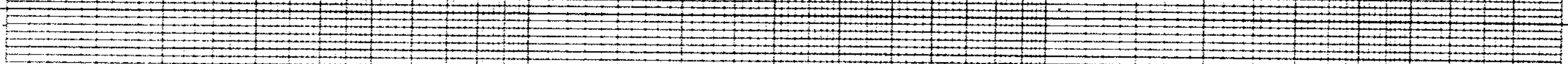

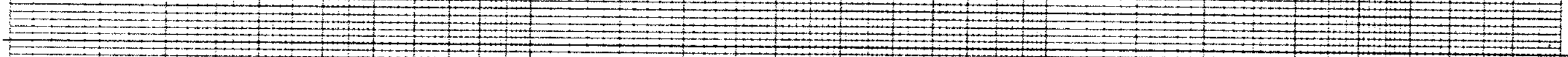

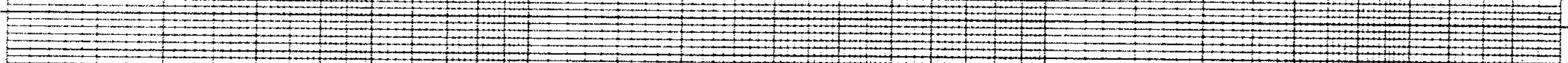

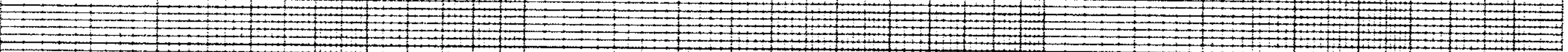

000

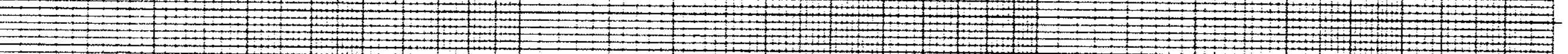

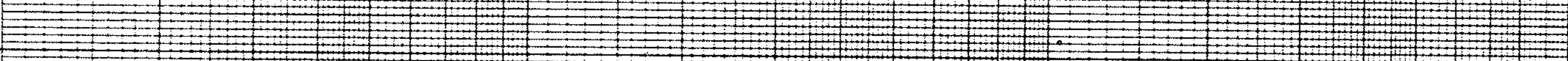

000

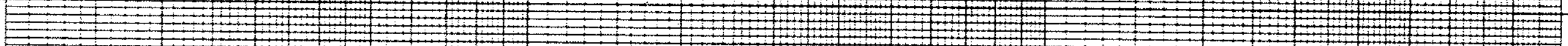

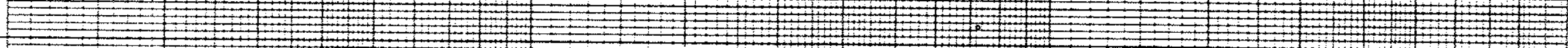

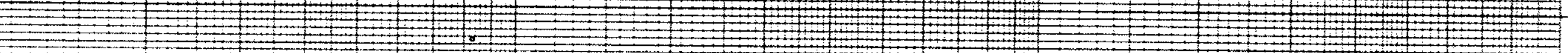

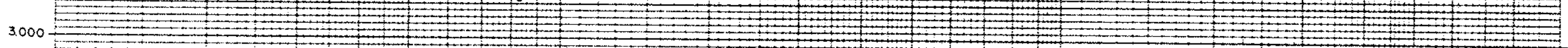

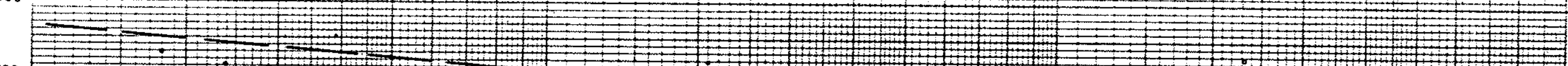

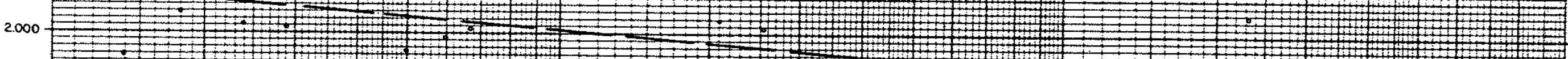

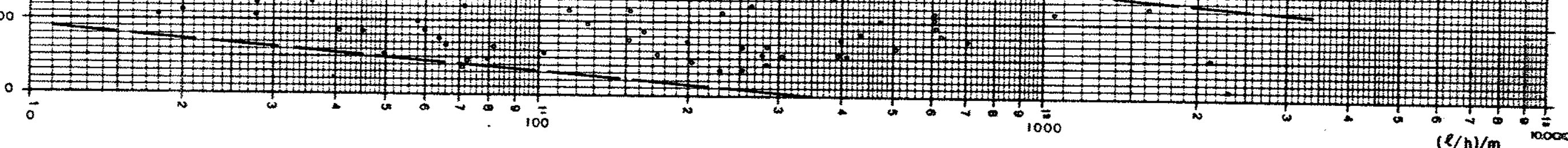


QUADRO 7.1 - CORRELAÇÃO ENTRE YAZAO ESPECIFICA E RESIDUO SECO NO R. G.NORTE OCIDENTAL

\begin{tabular}{|c|c|c|c|c|}
\hline & $X, Y$ & $\log X, \log Y$ & $\operatorname{logX}, Y$ & $X, \log Y$ \\
\hline MEDIA DA VARIÁVEL DEPENDENTE & $1.544,48$ & 3,040 & $1.544,48$ & 3,04 \\
\hline MEDIA DA VARIAVEL INDEPENDENTE & 651,57 & 2,200 & 2,20 & 651,57 \\
\hline DESVIO PADRAO DA VARIAVEL DEPENDENTE & $1.740,48$ & 0,332 & $1.740,48$ & 0,33 \\
\hline DESVIO PADRAOO DA VARTAVVEL INDEPENDENTE & $1.968,98$ & 0,686 & 0,68 & $1.968,98$ \\
\hline VALOR DO COEFICIENTE $\bar{b}$ & $1.547,70$ & 3,240 & $2.064,37$ & $3,0.49$ \\
\hline VALOR DO COEFICIENTE a & $-4,2.10^{-3}$ & $-0,089$ & $-235,89$ & $9,56 \cdot 10^{-7}$ \\
\hline COEFICIENTE DE CORRELAÇÃO (RI & $-0,0056$ & $-0,185$ & $-0,09$ & $-0,056$ \\
\hline
\end{tabular}


como se observa no gräfico, pode-se ainda visualizar uma "tendên. cia" a uma correlação atravës de uma relação inversa entre os ele mentos em estudo. Essa"tendência" ê assinalada no gräfico por uma faixa de concentração dos pontos, com ligeira inclinação da esquer da para a direita do gräfico. De qualquer modo, a relação não $\vec{e}$ muito boa, devido provavelmente a participação de outros fatores que atuam simultaneamente, como o clima, a profundidade de entrada d'ägua, o tipo de rocha (em menor proporção), dentre outros.Se os poços fossem todos perfurados numa mesma situação com relação aos demais fatores, certamente a relação R.S. x Q/s seria: bem mais ressaltada.

Em pesquisas antèriores, essa relação tem sido comprovada, " como no trabalho de COSTA, (1965) na região de Monteiro-PB e LEAL( 1968) em diversas äreas do nordeste. Segundo COSTA,op.cit., os 23 poços perfurados em fraturas transversais e com vazão mëdia de $5.140 \mathrm{l} / \mathrm{h}$ apresentaram um resíduo seco mëdio de $2.090 \mathrm{mg} / 1$, enquanto nos 24 poços perfurados em fraturas angulares, com vazão mëdia de $2.580 \mathrm{l} / \mathrm{h}$, tiveram um resíduo seco mëdio de $3.970 \mathrm{mg} / 1$. Para LEAL,op.cit., que analisou os cloretos (principal anion das ăguas do "cristalino" do nordeste) das äguas de 230 poços distribuî́dos em vărias regióes do nordeste e chegou a seguinte conclusão:

$\begin{array}{cc}\text { Vazão }(1 / \mathrm{h}) & \text { C1oretos } \\ <2.000 & 2.400 \\ 2.000-4.000 & 1.960 \\ 4.000-6.000 & 1.700 \\ 6.000-8.000 & 1.160 \\ 8.000-10.000 & 980 \\ >10.000 & 730\end{array}$

7.2.2. RELAÇAO VAZAO ESPECIFICA X TIPO DE ROCHA

Värias tentativas de correlação foram feitas para avaliar a melhor maneira de relacionar esses dois parâmetros. Inicialmente foram separados por Estado e por região, tomando-se toda a população amostrada. 
QUADRO 7.2 - VAZAO ESPECIFICA POR TIPO LITOLOGICO NO ESTADO DO RIO GRANDE DO NORTE (TODOS OS POÇOS)

\begin{tabular}{|l|r|r|r|r|r|}
\hline ROCHA & $\overline{\mathrm{X}}(1 / \mathrm{h} / \mathrm{m}$ & $\sigma(1 / \mathrm{h}) \mathrm{m}$ & C.V.(\%) & \multicolumn{1}{|c|}{$N^{\circ}$} & : TOT. \\
\hline Gnaisse & 730,04 & $1.991,46$ & 272,79 & 291 & 68,8 \\
Granito & 432,50 & 664,25 & 153,58 & 64 & 15,1 \\
Micaxisto & 504,80 & 915,05 & 181,27 & 46 & 10,9 \\
Migmatito & 655,44 & $1.205,62$ & 189,73 & 14 & 3,3 \\
Quartzito & 764,00 & 653,23 & 85,50 & 8 & 1,9 \\
\hline MEDTA: & 658,04 & & TOTAL: & 423 \\
\hline
\end{tabular}

QUADRO 7.3 - VAZAO ESPECIFICA POR TIPO LITOLOGICO NO ESTADO DA PARAIBA ( TODOS OS POÇOS )

\begin{tabular}{|l|r|r|r|r|r|}
\hline ROCHA & $\overline{\mathrm{X}}(1 / \mathrm{h}) \mathrm{m}$ & $\sigma(1 / \mathrm{h}) \mathrm{m}$ & C.V. $(\%)$ & \multicolumn{1}{|c|}{$\mathrm{N}^{\circ}$} & $:$ TOT. \\
\hline Gnaisse & 334,22 & 557,11 & 166,69 & 220 & 56,6 \\
Granito & 219,64 & 400,30 & 182,25 & 45 & 11,6 \\
Micaxisto & 518,94 & 910,89 & 175,53 & 51 & 13,1 \\
Migmatito & 173,96 & 223,98 & 128,75 & 27 & 6,9 \\
Quartzito & 227,00 & 159,12 & 70,01 & 7 & 1,8 \\
Filito & 359,69 & 479,29 & 133,25 & 39 & 10,0 \\
\hline MEDIA: & 334,68 & & TOTAL: & 389 \\
\hline
\end{tabular}

\begin{tabular}{|c|c|c|c|c|}
\hline \multirow{7}{*}{$\begin{array}{l}\text { Resumo dos dados } \\
\text { para a população } \\
\text { de } 812 \text { poços nos } \\
\text { dois Estados: }\end{array}$} & ROCHA: & $\overrightarrow{\mathrm{X}}$ & $N^{8}$ & $\%$ \\
\hline & Gnaisse & 559,63 & 511 & 62,9 \\
\hline & Granito & 334,62 & 109 & 13,4 \\
\hline & Micaxisto & 512,23 & 97 & 11,9 \\
\hline & Migmatito & 331,54 & 41 & 5,0 \\
\hline & Quartzito & 513,40 & 15 & 1,8 \\
\hline & Filito & 359,69 & 39 & 4,8 \\
\hline
\end{tabular}


QUADRO 7.4 - VAZÃO ESPECIFICA PQR TIPO LITOLOGICQ NO ESTADO DO R.G.NORTE (Amostragem no interv.50-1000 1/h/m)

\begin{tabular}{|l|c|c|c|c|c|}
\hline ROCHA & $\overrightarrow{\mathrm{X}}(1 / \mathrm{h}) \mathrm{m}$ & $\dot{\sigma}(1 / \mathrm{h}) \mathrm{m}$ & $\mathrm{C} . \mathrm{V} .(\%)$ & N $\%$ & \% ToT. \\
\hline Gnaisse & 319,48 & 255,10 & 79,85 & 198 & 70,7 \\
Granito & 258,11 & 207,94 & 80,56 & 40 & 14,3 \\
Micaxisto & 255,24 & 221,02 & 86,59 & 29 & 10,4 \\
Migmatito & 300,90 & 227,43 & 75,58 & 8 & 2,9 \\
Quartzito & 275,20 & 154,35 & 56,09 & 5 & 1,8 \\
\hline MEDIA & 302,73 & & TOTAL: & $\begin{array}{l}280 \text { (66,6\% } \\
\text { da popuíação) }\end{array}$ \\
\hline
\end{tabular}

QUADRO 7.5 - VAZAOO ESPECIFICA POR TIPO LITOLOGICO NO ESTADO DA PARAIBA (Amostragem no intervalo $50-1000 \quad 1 / \mathrm{h} / \mathrm{m}$ )

\begin{tabular}{|l|c|c|c|c|c|}
\hline ROCHA & $\overline{\mathrm{X}}(1 / \mathrm{h}) \mathrm{m}$ & $\sigma\left(1 / \mathrm{h} \gamma_{\mathrm{m}}\right.$ & $\mathrm{C} . V .\left(\frac{0}{0}\right)$ & $N^{8}$ & $\mathrm{o}_{0}$ TOT. \\
\hline Gnaisse & 260,07 & 214,85 & 82,61 & 157 & 58,4 \\
Micaxisto & 249,94 & 211,00 & 84,42 & 32 & 11,9 \\
Filito & 211,58 & 204,21 & 96,52 & 31 & 11,5 \\
Migmatito & 248,50 & 241,93 & 97,36 & 18 & 6,7 \\
Granito & 243,31 & 269,23 & 110,65 & 26 & 9,7 \\
Quartzito & 300,60 & 128,40 & 42,71 & 5 & 1,8 \\
\hline MEDrA: & 251,64 & & TOTAL: & 269 (69,3\% da \\
\end{tabular}

Resumo dos dados pa
ra a amostragem de
549 poços (68\% da po
pulação de dados)
nos dois Estados: $\quad\left\{\begin{array}{llrr}\text { ROCHA: } & \bar{X} & \text { N } & \% \\ \text { Gnaisse } & 293,21 & 355 & 64,7 \\ \text { Granito } & 252,28 & 66 & 12,0 \\ \text { Micaxisto } & 252,46 & 61 & 11,1 \\ \text { Migmatito } & 264,62 & 26 & 4,7 \\ \text { Quartzito } & 287,90 & 10 & 1,8 \\ \text { Filito } & 211,58 & 31 & 5,6\end{array}\right.$


A separação por região foi constatada ser desnecessäria , pois as diferenças que cada tipo litico apresentaram de uma região para outra não eram muito significativas.

Com relação ao nủmero de amostras, os coeficientes de vari ação revelaram uma dispersão absurda quando se levava em conta to da a população, como se pode ver nosQuadros 7.2 e 7.3 . Verifica-se que, sobretudo no R.G. do Norte, os coeficientes de varia çäo chegam a ultrapassar de $200 \%$, sendo para todas as rochas, à exceção do quartzito, superiores a $150 \%$. Por outro lado, os valores mẻdios se acham completamente discrepantes, como por exemplo o gnaisse, que no R.G.do. Norte possui mais do dobro da mëdia da paraiba; igualmente distorcidos estão os valores mëdios do grani to, do micaxisto, do migmatito e do quartzito.

Depois de algumas tentativas, chegou-se a uma amostragem mais realista, considerando o intervalo de vazão específica superior a $50(1 / \mathrm{h}) / \mathrm{m}$ e inferior a $1.000(1 / \mathrm{h} / \mathrm{m}$.

A amostra consideradanesse intervalo correspondeu a $68^{\circ}$ da população tota1, ou seja a aproximadamente $2 / 3$ dos dados disponiveis. Os coeficientes de variação para cada tipo lítico variaram desde $56 \%$ atẻ $110 \%$, tendo apenas em um caso, ultrapassado os $100 \%$

Nos Quadros 7.4 e 7.5, são mostrados os valores médios, desvio padrão, coeficiente de variação e nümero de amostras e participação percentual para cada tipo de rocha. A comparação en tre a participação percentual de cada rocha da população com a da amostragem escolhida $\ddot{e}$ quase a mesma, o que demonstra uma boa re presentatividade da amostra traba1hada.

Serä inicialmente analisada a amostra tomada no intervalo citado.

o tipo de rocha dominante em ambos os Estados $\vec{e}$ o gnaisse, com $70 \%$ no R.G. do Norte e $58 \%$ na Paraîba. A vazão específica më dia nesses gnaisses é a mais elevada dentre todas as demais. A diferença maior entre os dois Estados, ficou por conta dos migmatitos que no R.G.do Norte ocupava a $2^{\text {a }}$ posição, com mểia de 300

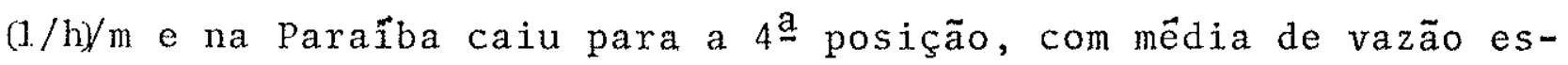
pecifica de $248(1 / \mathrm{h} / \mathrm{m}$. De um modo geral, não ocorreram grandes di ferenças entre os dois Estados, sendo a mêdia geral, na ordem decrescente, a seguinte: 


\begin{tabular}{|c|c|c|c|c|c|c|}
\hline $1{ }^{9}-$ Gnaisse & $-293,21$ & $(1 / h) / m$ & $(64,7 \%)$ & com & 355 & poços \\
\hline $2^{\circ}-$ Quartzito & $-287,90$ & $"$ & $(1,8 \%)$ & " & 10 & $"$ \\
\hline $3:-$ Migmatito & $-264,62$ & $"$ & $\left(4,7 \frac{\circ}{0}\right)$ & $"$ & 26 & $"$ \\
\hline $48-$ Micaxisto & $-252,46$ & $"$ & $(11,1 \%)$ & $"$ & 61 & $"$ \\
\hline $5:-G r a n i t o$ & $-252,28$ & $"$ & $(12,0 \%)$ & $"$ & 66 & $"$ \\
\hline $6:-F i l i t o$ & $-211,70$ & $"$ & $(5,6 \%)$ & $"$ & 31 & $"$ \\
\hline $\begin{array}{l}\text { Mëdia Gera } 1 \\
\text { (ponderada) }\end{array}$ & 277,70 & $"$ & & " & 549 & $"$ \\
\hline
\end{tabular}

Dentro do intervalo considerado na amostragem, as diferenças de vazão especifića mẻdia de um tipo lítico para outro não foram muito grandes; até mesmo os valores extremos do gnaisse e filito ficaram pröximos, sendo o ültimo equivalente a $72 \%$ do primeiro.

Da anälise da população integral de dados, pode-se esta belecer os seguintes valores mëdios de vazão especifica, para os dois Estados reunidos na ordem decrescente:

\begin{tabular}{|c|c|c|c|c|c|c|c|}
\hline - Gnaisse & 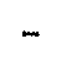 & 559,63 & $(1 / \mathrm{h} / \mathrm{m}$ & $(62,9 \%)$ & $\mathrm{com}$ & 511 & poço \\
\hline :- Quartzito & - & 513,40 & $"$ & $(1,8 \%)$ & $"$ & 15 & $"$ \\
\hline 9- Micaxisto & - & 512,23 & 11 & $(11,9 \%)$ & $"$ & 97 & $"$ \\
\hline :- Filito & - & 359,69 & $"$ & $(4,8 \%)$ & $"$ & 39 & $"$ \\
\hline ?- Granito & - & 4,62 & " & $(3,4 \%)$ & $" \prime$ & 109 & $"$ \\
\hline -. Migmatito & - & 331,54 & $"$ & $(5,0 \%)$ & $"$ & 41 & $"$ \\
\hline
\end{tabular}

A comparação entre os dois resultados revela:que:

$-1^{\circ}$ ) em ambos, o gnaisse e o quartzito ocupam, respectivamente, $01^{\circ}$ e $02^{\circ}$ lugares em vazäo especifica.

$\left.-2^{\circ}\right)$ a sequência de ocorrência è praticamente a mesma nas duas relações, com:gnaisse - granito - micaxisto - migmatito - fi 1ito - quartzito (as posiçőes do migmatito e filito estão inverti das na amostragem).

-3) para a população integral, ocorrem dois grupos de vazões especificas, mais ou menos comuns, que são o gnaisse - quart zito - micaxisto, com mëdia ponderada de 551 ( $/ / \mathrm{h} / \mathrm{m}$ e o filito granito - migmatito, com mëdia ponderada de $339(1 / \mathrm{h} / \mathrm{m}$; enquanto isso, a amostragem näo revela grupos distintos e homogêneos, tendo todos os tipos 1 íticos uma vazão mëdia ponderada de $278(1 / \mathrm{h}) \mathrm{m}$. 
Os estudos precedentes apresentaram resultados parecidos a esse. LEGRAND(1959) o SIVER(1064) apresentaram a seguinte relação, em 490 poços estudados na região de Carolina do Norte:

$\begin{array}{llllll}1:- \text { Micaxisto } & -4.9801 / \mathrm{h} & \text { en } & 168 & \text { poços } \\ 2 \circ-\text { Granito } & -3.3001 / \mathrm{h} & " & 234 & " \\ 3 \circ-\text { Diorito } & -3.1201 / \mathrm{h} & " & 69 & " \\ 4:- \text { Ardösia } & -2.40 .1 / \mathrm{h} & " & 19 & " \\ \text { Mëdia ponderada }-3.7801 / \mathrm{h} & " & 490 & "\end{array}$

Os mesmos autores, encontraram em 289 poços, na região de pittsylvânia e Halifax, a seguinte relação:

\begin{tabular}{|c|c|c|c|c|c|}
\hline $1^{\circ}$ - Gnaisses variados & -3.790 & $1 / \mathrm{h}$ & em & 180 & poços \\
\hline $2^{\circ}-$ Granito gnaissico & -3.200 & $"$ & " & 26 & $"$ \\
\hline 3:- Micaxisto/granito & -3.000 & $"$ & $"$ & 20 & $"$ \\
\hline $4^{\circ}-$ Micaxisto & -2.500 & $"$ & $" 1$ & 34 & $"$ \\
\hline 5:- Xistos verdes & -1.800 & $"$ & $"$ & 14 & $"$ \\
\hline $6:-\operatorname{Ardōsia~}$ & -1.600 & $"$ & $"$ & 15 & $"$ \\
\hline Mëdia Geral & 3.320 & $"$ & $"$ & 289 & $"$ \\
\hline
\end{tabular}

Em trabalho apresentado no Simpôsio Nacional de Agua Sub terrânea em Rochas Fraturadas, em 1979, no Recife, CosTA, apresen tou uma estatistica com 274 poços perfurados por vârias distintas companhias, na região do Alto paraíba. Os resultados oferecidos foram:

\begin{tabular}{|c|c|c|c|c|c|c|}
\hline 19-Micaxisto & - & 3.240 & $1 / \mathrm{h}$ & em & 28 & poços \\
\hline $2^{\circ}-$ Gnaisse & - & 3.060 & $"$ & $"$ & 169 & $"$ \\
\hline 3:- Migmatito & - & 2.556 & $"$ & $"$ & 17 & $"$ \\
\hline $4:-$ Granito & - & 1.825 & $"$ & $"$ & 29 & " \\
\hline
\end{tabular}

Em vista dos resultados obtidos, pode-se adotar a seguinte relaçäo decrescente, de tipo litico, de acordo com a "aptidão" para armazenamento e fornecimento de ägua subterrânea:

1\%) Gnaisses, quartzitos, e pegmatitos

28) Micaxistos

$\left.3^{\circ}\right)$ Granitos e rochas granulares magmäticas, além de migmatitos não orientados.

$\left.4^{\circ}\right)$ Filito, ardösia e xistos verdes. 
Esse resultado vem corroborar as observações efetuadas no capitulo 2 , em que foram consideradas as caracteristicas físicas das rochas, ale ẻm da orientação da estrutura, de granulação .. dos cristais e outras feições que influem para produzirem maior nüme ro de fraturas e maior abertura das mesmas.

Finalmente, deve ser citada a participação dos tipos rochosos nos poços secos. Dos 396 poços secos do R.G. do Norte, os gnaisses lideram a ocorrência, com $66.9 \%$, seguidos do granito $23,2 \%)$, do micaxisto $(4,8 \%)$, do migmatito $(2,5 \%)$, do quartzito $1,5 \%$ ) e outros tipos $(1,0 \%)$, ou seja, praticamente a mesma sequên cia de ocorrência dos poços com âgua.

\subsubsection{RELAÇAO VAZđO ESPECIFICA X TIPO DE FRATURA}

Conforme jâ abordado em 6.1 , a amostragem dos poços uti1izados para o estudo das fraturas correspondeu a $30 \%$ do total trabalhado, distribuîdos numa vasta ärea, em que foram abrangidos todos os estilos tectônicos vigentes na área de estudo e todos os tipos de fratura presentes na ärea como um todo.

A anâlise estrutural foi baseada em foto-interpretação na escala de 1:70.000 e parcialmente $1: 25.000$ com checagem de campo em pontos duvidosos, tendo ainda como apoio cartográfico e geológi co os mapas plani-altimëtricos da SUDENE, na escala de 1:100.000 e os mapas geológicos tambëm 1:100.000 elaborados pe1o DNPM/CPRM, no trabalho retro-mencionado.

Não foi procedido um estudo estrutural mais profundo, com diagramas polares ou de frequêncìa de fraturas, em virtude de não ter sido possível a visita de mais que $20 \%$ dos poços trabalhados, optando-se assim por uma homogeneização de tratamento de dados pa ra toda a amostra usiada. Mesmo nos poços visitados, nem sempre o afloramento era rico em fraturas, que permitisse uma medição quan titativa adequada.

De qualquer forma, o resultado obtido pode ser considerado satisfatório, prescindindo inteiramente de um estudo mais deca lhado, para a finalidade a que se destina. 
As fraturas assinaladas foram classificadas levando em conta a relação com as direçôes de xistosidade ou lineamentos es truturais bem como com relação a gênese. Assim, por exemplo, uma fratura longitudinal tracional é paralela aos planos de xistosida de, sendo originada por um esforço tracional ( ou componente tra cional $\sigma_{3}$ de um esforço compressivo $\sigma_{1}$ ); podem ser 'deijidos a alivio de pressäo ou associadas a dobras antiformes pröximas ao plano axial (bc de SANDER). Por outro Iado, uma fratura Iongitudi nal de cisalhamento, desenvolve-se paralelamente ao plano de xistosidade sendo provocado por um esforço compressivo atuando obliquamente ao referido plano. Algumas fraturas longitudinais (geome tricamente), não puderam. ser definidas quanto a gênege, dar classificação adotada de longitudinal indefinida. Em alguns casos, a fratura não ficou bem característica nem quanto a geometria( em rochas não orientadas, p.e.) nem quanto a gênese, sendo entäo classificada como fratura näo caracterizada. Finalmente, em a1guns casos, o poço foì perfurado em local onde, superficialmente, não foi detectada nenhuma fratura.

Conforme pode ser visto no Quadro 7.6, os poços que forneceram melhores vazöes foram aqueles locados em fraturas trans versais tracionais, com uma mëdia de $1.141(1 / \mathrm{h}) / \mathrm{m}$ no Estado do $\mathrm{R}$. G. do Norte e $907(1 / \mathrm{h}) / \mathrm{m}$ no Estado da Paraíba, ou no total da ārea, para 58 poços analisados, com uma vazão específica mêdia de 1.076 $(1 / \mathrm{h} / \mathrm{m}$.

Seguiram-se na ordem decrescente as fraturas longitudinais tracionais, com a vazão específica mëdia para a ärea total, de $484(\mathrm{l} / \mathrm{h}) / \mathrm{m}$.

Dentre as fraturas longitudinais indefinidas e das não ca racterizadas, certamente existem algumas tracionais e outras de cisalhamento, o que conferiu à mêdia para os dois tipos, valores intermediärios entre aqueles de fraturas tracionais (transversais ou longitudinais) e de cisalhamento (angulares ou longitudinais).

Assim, as fraturas longitudinais indefinidas forneceram vazões específicas mëdias da ordem de $231(1 / \mathrm{h} / \mathrm{m}$, enquanto as fraturas näo caracterizadas alcançaram a vazão mëdia de $351(1 / \mathrm{h}) / \mathrm{m}$.

As fraturas de cisalhamento, como era esperado, forneceram as mais reduzidas vazões nos poços que thes interceptaram : $114 \mathrm{l} / \mathrm{h} / \mathrm{m}$ nas fraturas angulares de cisalhamento e $106 \mathrm{l} / \mathrm{h} / \mathrm{m}$ nas fraturas longitudinais de cisalhamento. 
QUADRO 7.6 - VALORES DE VAZÃO ESPECIFICA POR TIPO DE FRATURA

\begin{tabular}{|c|c|c|c|c|c|c|c|c|c|c|}
\hline \multirow{2}{*}{$\begin{array}{l}\text { TIPO DE } \\
\text { FRATURA }\end{array}$} & \multirow[b]{2}{*}{ VALOR } & \multicolumn{3}{|c|}{ RIO GRANDE DO NORTE } & \multicolumn{3}{|c|}{ PARAIBA } & \multicolumn{3}{|c|}{ TOTAL } \\
\hline & & $(1 / \mathrm{h}) / \mathrm{m}$ & No & $\because$ & $(1 / h) / m$ & $N^{\circ}$ & $\hat{\circ}$ & $\mathrm{Q} / \mathrm{i} \mathrm{i} / \mathrm{m}$ & No & $\%$ \\
\hline $\begin{array}{l}\text { Transversal } \\
\text { tracional }\end{array}$ & $\begin{array}{l}\text { MAXXIMO } \\
\text { MINIMO } \\
\text { MEDIO }\end{array}$ & $\begin{array}{r}8.034 \\
28 \\
1.141 \\
\end{array}$ & 42 & 28,2 & $\begin{array}{r}3.714 \\
75 \\
\quad 907 \\
\end{array}$ & 16 & 16,5 & $\begin{array}{r}8.034 \\
28 \\
1.076 \\
\end{array}$ & 58 & 23,9 \\
\hline $\begin{array}{l}\text { Angular de } \\
\text { cisalhamento }\end{array}$ & $\begin{array}{l}\text { MAXIMO } \\
\text { MINIMO } \\
\text { MEDIO }\end{array}$ & $\begin{array}{r}408 \\
13 \\
98 \\
\end{array}$ & 23 & 15,4 & $\begin{array}{r}504 \\
10 \\
124 \\
\end{array}$ & 37 & 38,1 & $\begin{array}{r}504 \\
10 \\
114 \\
\end{array}$ & 60 & 24,3 \\
\hline $\begin{array}{l}\text { Longitudinal } \\
\text { tracional }\end{array}$ & $\begin{array}{l}\text { MAXIMO } \\
\text { MINIMO } \\
\text { MEDIO }\end{array}$ & $\begin{array}{r}1.758 \\
116 \\
546 \\
\end{array}$ & 8 & 5,4 & $\begin{array}{l}356 \\
112 \\
234 \\
\end{array}$ & 2 & 2,1 & $\begin{array}{r}1.758 \\
112 \\
484 \\
\end{array}$ & 10 & 4,0 \\
\hline $\begin{array}{l}\text { Longitudinal de } \\
\text { cisalhamento }\end{array}$ & $\begin{array}{l}\text { MAXXIMO } \\
\text { MINIMO } \\
\text { MEDIO }\end{array}$ & $\begin{array}{l}86 \\
19 \\
50\end{array}$ & 6 & 4,0 & $\begin{array}{r}614 \\
23 \\
162\end{array}$ & 6 & 6,2 & $\begin{array}{r}614 \\
19 \\
106\end{array}$ & 12 & 4,8 \\
\hline $\begin{array}{l}\text { Longitudinal } \\
\text { indefinida }\end{array}$ & $\begin{array}{l}\text { MAXIMO } \\
\text { MINIMO } \\
\text { MEDIO }\end{array}$ & $\begin{array}{r}714 \\
29 \\
264\end{array}$ & 13 & 8,7 & $\begin{array}{r}398 \\
14 \\
161\end{array}$ & 6 & 6,2 & $\begin{array}{r}714 \\
14 \\
231\end{array}$ & 19 & 7,7 \\
\hline $\begin{array}{l}\text { Não } \\
\text { caracterizada }\end{array}$ & $\begin{array}{l}\text { MAXIMO } \\
\text { MINIMO } \\
\text { MEDIO }\end{array}$ & $\begin{array}{r}1.955 \\
32 \\
401 \\
\end{array}$ & 27 & 18,1 & $\begin{array}{r}900 \\
16 \\
218\end{array}$ & 10 & 10,3 & $\begin{array}{r}1.955 \\
16 \\
351\end{array}$ & 37 & 15,0 \\
\hline Sem fraturas & $\begin{array}{l}\text { MAXIMO } \\
\text { MINIMO } \\
\text { MEDIO }\end{array}$ & $\begin{array}{r}334 \\
14 \\
59 \\
\end{array}$ & 30 & 20,1 & $\begin{array}{r}290 \\
15 \\
85 \\
\end{array}$ & 20 & 20,6 & $\begin{array}{r}334 \\
14 \\
70 \\
\end{array}$ & 50 & 20,2 \\
\hline MEDIA GERAL & & 476 & & & 262 & & & 391 & & \\
\hline
\end{tabular}


Finalmente aparecem os 50 poços sem fraturas, que forneceram uma vazão especifica mëdia de apenas $69 \mathrm{l} / \mathrm{h} / \mathrm{m}$.

Para uma melhor visualização da variação da vazão específica em função do tipo de fratura, foi estabelecida a relação de frequência dos tipos de fraturas, por faixas de vazāo específica (Quadro 7.7).

Do referido quadro, pode-se obter as seguintes conclusões:

a) as melhores vazões, acima de $1.000 a / h \gamma_{m}$ somente são obtidas quando o poço alcança fraturas tracionais;mesmo na faixa de 500 a $1.000(\mathrm{l} / \mathrm{h} / \mathrm{m}$ somente em casos excepcionais são obtidas em poços com fraturas não tracionais.

b) cerca de $70 \%$ dos poços que são servidos por fraturas de cisalhamento, possuem vazões especificas inferiores a $100 \mathrm{a} / \mathrm{h} \mathrm{ym}_{\mathrm{m}}$.

c) mais de $80 \%$ dos poços locados sem fraturas superficiais, fornecem vazões inferiores a $100(\mathrm{l} / \mathrm{h} / \mathrm{m}$, ficando os $20 \%$ restantes na faixa de 100 a $500(1 / \mathrm{h} / \mathrm{m}$.

d) o conjunto de fraturas transversais tracionais com angulares de cisalhamento, representa $60 \%$ do tota1 das fraturas analisadas na área amostrada. Esse percentual deverä ultrapassar os $75^{\circ}$, considerando que a maioria das fraturas não caracterizadas deve ser te um dos dois desses tipos.

Apesar de constar no cadastro de poços em anexo, a profun didade em que foram interceptadas as fraturas, não foi efetuada qualquer anälise do seu comportamento em profundidade, pois a simples presença de um maior ou menor nümero de fraturas não implica em maior ou menor potencialidade hîdrica do meio fissurado. Assim ê que, na maioria dos poços considerados secos, mesmo naque les que não apresentaram nenhuma ägua, foram sempre interceptadas vārias fraturas. Por outro lado, as duas companhias de perfuração adotam critêrios diferentes na anotação dos dados dos poços ; enquanto o $C D M-R N$ registra todas as fraturas interceptadas pelo furo, a CDRM-PB registra apenas as principais, que apresentam contribuição d'ägua. Dessa maneira, uma anälise comparativa conduziria a resultados falsos no contexto da ärea integrada. 
QUADRO 7.7 - FREQUENCIA DOS TIPOS DE FRATURAS POR FAIXAS DE VAZAO ESPECIFICA

\begin{tabular}{|c|c|c|c|c|c|c|c|c|c|c|c|c|c|c|}
\hline \multirow{2}{*}{$\begin{array}{l}\text { TIPOS DE } \\
\text { FRATURAS }\end{array}$} & & \multicolumn{3}{|c|}{$Q / s<100$} & \multicolumn{3}{|c|}{$100<Q / s<500$} & \multicolumn{3}{|c|}{$500<Q / s<1000$} & \multicolumn{3}{|c|}{$Q / s>1000$} & \multirow[b]{2}{*}{ TOTAL } \\
\hline & & $\mathrm{PB}$ & RN & TOT. & $\mathrm{PB}$ & $\mathrm{RN}$ & TOT. & $\mathrm{PB}$ & $\mathrm{RN}$ & TOT. & $\mathrm{PB}$ & $\mathrm{RN}$ & TOT. & \\
\hline \multirow{2}{*}{$\begin{array}{l}\text { Transversal } \\
\text { tracional }\end{array}$} & $N: A M$ & 2 & 1 & 3 & 8 & 12 & 20 & 2 & 15 & 17 & 4 & 14 & 18 & 58 \\
\hline & $\%$ & 12,5 & 2,4 & 5,2 & 50,0 & 28,6 & 34,5 & 12,5 & 35,7 & 29,3 & 25,0 & 33,3 & 31,0 & 23,6 \\
\hline \multirow{2}{*}{$\begin{array}{l}\text { Angular de } \\
\text { cisalhamento }\end{array}$} & N:AM. & 25 & 16 & 41 & 11 & 7 & 18 & 1 & 0 & 1 & 0 & 0 & 0 & 60 \\
\hline & $\%$ & 67,6 & 69,6 & 68,3 & 29,7 & 30,4 & 30,0 & 2,7 & 0 & 1,7 & 0 & 0 & 0 & 24,4 \\
\hline \multirow{2}{*}{$\begin{array}{l}\text { Longitudinal } \\
\text { tracional }\end{array}$} & N:AM. & 0 & 0 & 0 & 2 & 6 & 8 & 0 & 0 & 0 & 0 & 2 & 2 & 10 \\
\hline & $\frac{\%}{0}$ & 0 & 0 & 0 & 100,0 & 75,0 & 80,0 & 0 & 0 & 0 & 0 & 25,0 & 20,0 & 4,1 \\
\hline \multirow{2}{*}{$\begin{array}{l}\text { Longitudinal } \\
\text { de cisalham. }\end{array}$} & N:AM. & 4 & 6 & 10 & 1 & 0 & 1 & 1 & 0 & 1 & 0 & 0 & 0 & 12 \\
\hline & $\%$ & 66,7 & 100,0 & 83,3 & 16,7 & 0 & 8,3 & 16,7 & 0 & 8,3 & 0 & 0 & 0 & 4,9 \\
\hline \multirow{2}{*}{$\begin{array}{l}\text { Longitudinal } \\
\text { indefinida }\end{array}$} & N:AM. & 3 & 3 & 6 & 3 & 8 & 11 & 0 & 2 & 2 & 0 & 0 & 0 & 19 \\
\hline & $\%$ & 50,0 & 23,1 & 31,5 & 50,0 & 61,5 & 57,9 & 0 & 15,4 & 10,5 & 0 & 0 & 0 & 7,7 \\
\hline \multirow{2}{*}{$\begin{array}{l}\text { Não caracte } \\
\text { rizada }\end{array}$} & N:AM. & 4 & 9 & 13 & 5 & 12 & 17 & 1 & 1 & 2 & 0 & 5 & 5 & 37 \\
\hline & $\%$ & 40,0 & 33,3 & 35,1 & 50,0 & 44,4 & 45,9 & 10,0 & 3,7 & 5,4 & 0 & 18,5 & 13,5 & 15,0 \\
\hline \multirow[t]{2}{*}{ Sem fraturas } & NOAM. & 14 & 27 & 41 & 6 & 3 & 9 & 0 & 0 & 0 & 0 & 0 & 0 & 50 \\
\hline & $\%$ & 70,0 & 90,0 & 82,0 & 30,0 & 10,0 & 18,0 & 0 & 0 & 0 & 0 & 0 & 0 & 20,3 \\
\hline \multirow{2}{*}{$\begin{array}{l}\text { Para todas } \\
\text { as fraturas }\end{array}$} & N:AM. & 52 & 62 & 114 & 36 & 48 & 84 & 5 & 18 & 23 & 4 & 21 & 25 & 246 \\
\hline & & 53,6 & 41,6 & 46,3 & 37,1 & 32,2 & 34,1 & 5,2 & 12,1 & 9,3 & 4,1 & 14,1 & 10,2 & 100 \\
\hline
\end{tabular}

OBSERVAÇOES: $1^{\circ}$ ) para cada faixa de $Q / s$, o no Estado refere-se ao total daquele tipo de fratura 29) o percentual dos totais de cada faixa de $Q / s$ referem-se ao total daquele tipo de fratura, apre sentado na ültima coluna; $\left.3{ }^{\circ}\right)$ o percentual apresentado na ültima coluna refere-se ao total dos vários tipos de fraturas. Abreviaturas: $Q / S=$ vazão específica; $R N=R$.G.do Norte; $P B=P a r a i b a$ 
De qualquer modo, esses dados serviram para a anälise da relação entre a vazão específica e a profundidade do poç@, rea1izada aträs.

Apesar da grande importância desempenhada pelas estruturas rupturais na potencialidade das âguas subterrâneas em rochas cristalinas, não foram encontrados, a nîvel internacional, trabathos a esse respeito. Um dos poucos trabalhos existentes (ünico do conhecimento do autor dessa pesquisa) ë o de CosTA(1965), que estabeleceu relações entre diferentes tipos de fraturas (classifi cação apenas geomëtrica), a profundidade, a vazão (absoluta, no teste), a vazão especifica e o residuo seco. No Quadro 7.8 são apresentados os valores desse estudo, podendo-se comparar os resultados apresentados pelos poços perfurados em fraturas do tipo transversal (provavelmente tracional), angular (em geral, de cisa 1hamento), ortogonal (mais comum em rochas não orientadas) e 1ongitudinal (tracional, segundo o autor).

Verifica-se que as fraturas tipos transversal e longitudi nal apresentaram as melhores vazöes, se bem que, com valores bem inferiores àqueles oferecidos pela amostragem ora analisada. Os e levados valores oferecidos pela atual pesquisa, são fruto de a1guns casos isolados de muito boas vazöes, que fizeram elevar a mé dia gera1. No estudo efetuado com uma amsotragem de $68 \%$ da população, obteve-se um valor mëdio de vazão específica da ordem de $277 \mathrm{a} / \mathrm{h} \gamma_{\mathrm{m}}$.

As fraturas angulares do trabalho supra citado, apresenta ram vazões de apenas $39 \%$ daquelas oferecidas pelas fraturas trans versais. A amostragem dos poços que alcançaram fraturas ortogonais e longitudinais foi tão reduzida que não pôde ser tratada estatis ticamente.

7.2.4. RELAÇAO VAZAO ESPECTFICA X PROFUNDIDADE DO POÇO

Foram plotados, em grä́fico mono-log, os valores de vazão especifica (escala logaritmica) contra profundidade do poço, tanto no R.G.do Norte, como na Paraîba, ambos na região oriental, por possuir melhores vazões; se o resultado da correlação tivesse sido satisfatōrio, seria estabelecida a mesma relação para a regi ão ocidental. 
QUADRO 7.8 - RELAÇAO DA VAZÃO ESPECIFICA COM O TIPO DE FRATURA

\begin{tabular}{|l|c|c|c|c|c|}
\hline FRATURA & $\begin{array}{c}\text { NOMERO } \\
\text { POÇOS }\end{array}$ & $\begin{array}{c}\text { PROFUN } \\
\text { DIDADE } \\
(\mathrm{m})\end{array}$ & $\begin{array}{c}\text { VAZAO } \\
(1 / \mathrm{h})\end{array}$ & $\begin{array}{c}\text { VAZÃ } \\
\text { ESPEC } \\
(1 / \mathrm{h} / \mathrm{m}\end{array}$ & $\begin{array}{c}\text { RESIDUO } \\
\text { SECO } \\
(\mathrm{mg} / \mathrm{l})\end{array}$ \\
\hline Tr̂ansversal & 23 & 44 & 5.140 & 195,43 & 2.090 \\
Angular & 24 & 52 & 2.580 & 76,56 & 3.970 \\
Ortogonal & 2 & 55 & 220 & 5,68 & 9.470 \\
Longitudinal & 1 & 30 & 4.400 & 199,09 & 1.210 \\
\hline MEDIA GERAL & & 48 & 3.700 & 123,33 & 3.160 \\
\hline
\end{tabular}

(De acordo com COSTA, I965) 
As Figuras 7.3 e 7.4 mostram, respectivamente, essas rela ções no R.G. do Norte e na Paraíba. Como se observa em ambos os gräficos, não ficou caracterizada uma relação linear ou de qual quer outra natureza entre os diversos pontos, que, afora os alinha mentos, ao longo do nível de profundidade $60 \mathrm{~m}$, para o R.G. do Nor te e niveis $50 \mathrm{~m}$ e $40 \mathrm{~m}$, para a Paraíba, os demais pontos constituíram uma "nuvem de pontos" completamente aleatória.

Ap1icando o programa de regressão (mínimos quadrados) re tro-mencionado, obteve-se os valores estatísticos mostrados no Qua dro 7.9 , com índice de correlação em torno de $-0,3$ o que revela $u$ ma fraca correlação inversa entre as variáveis analisadas.

Buscando estabelecer alguma relação entre esses parâmetros, em vista da fraca correlação revelada matematicamente, foi elabora do um quadro de frequências, com dupla variảvel, entre a vazão es pecífica e a profundidade (ver Quadros 7.10 e 7.11).

Analisando-se as duas figuras e os dois quadros pode-se concluir que :

1.) dos poços com mais de $60 \mathrm{~m}$ de profundidade no R.G. do Norte, 46,5\% possuem vazões específicas inferiores a $100(\mathrm{l} / \mathrm{h} / \mathrm{m}$; na Paraíba, 44,7\% dos poços com mais de $50 \mathrm{~m}$ de profundidade também possuem vazöes especúficas inferiores a $100(1 / \mathrm{h} / \mathrm{m}$.

$\left.2^{\circ}\right)$ os poços que possuem vazão especifica menor de 100 ( $1 /$ h) $/ m$ possuem, na maior parte $(80,8 \%$ no R.G. do Norte . e $74 \%$ na Paraíba) profundidades elevadas (superiores a $60 \mathrm{~m}$ no R.G. do Norte e a $50 \mathrm{~m}$ na Paraiba).

$\left.3^{\circ}\right)$ dos poços que possuem vazāo específica maior: que $1.000(\mathrm{l} / \mathrm{h} / \mathrm{m}$, apenas $25 \%$ apresentam profundidades superiores aos $60 \mathrm{~m}$ no R.G.do Norte e somente $18 \%$ situam-se a profundidades superiores aos $50 \mathrm{~m}$ na Paraíba.

7.2.5. RELAÇÃ VAZAO ESPECIFTCA X ENTRADA D'AGUA

Uma outra relação executada foi a da vazão específica $x$ entrada d'ägua, através de uma anảlise das fraturas interceptadas pelos poços. Essa relação aparece associada a anterior em virtude da profundidade do poço e entrada d'ägua guardarem uma certa rela 
FIG. 7.3 - RELAÇĀO ENTRE PROFUNDIDADE DO POÇO E VAZĀO ESPECÍFICA (REGIĀO ORIENTAL DORIO G.DONORTE)

$(m)$

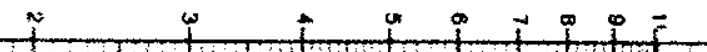

$\sim \omega$

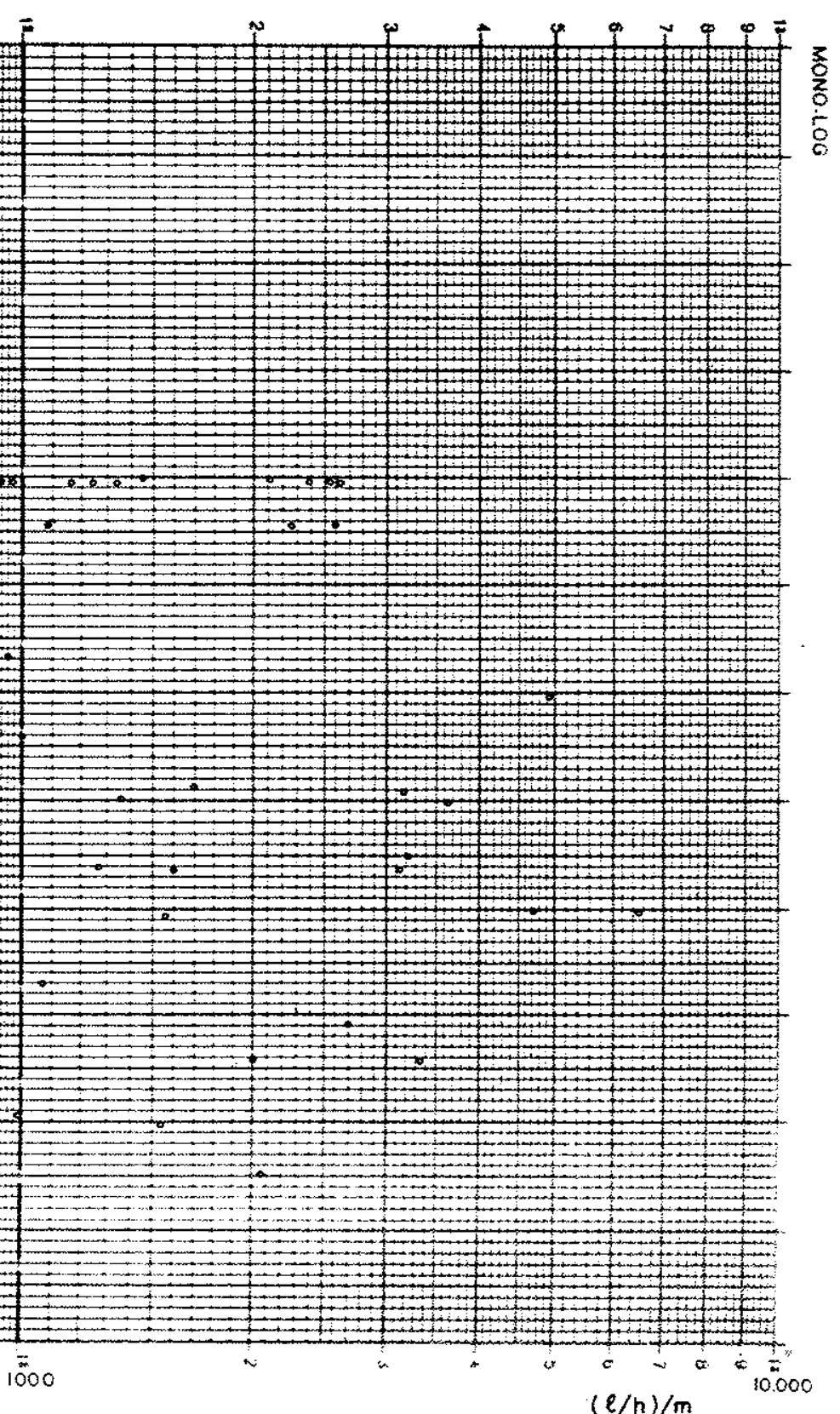

To

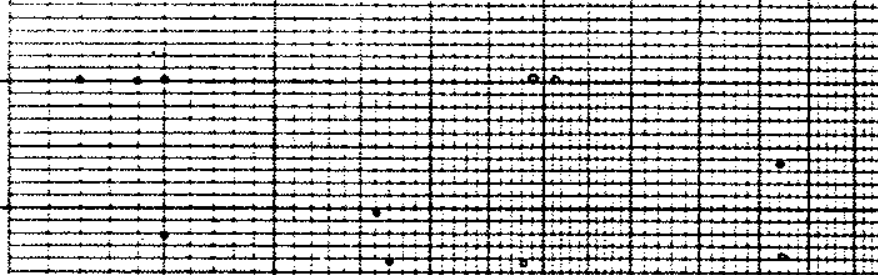

so

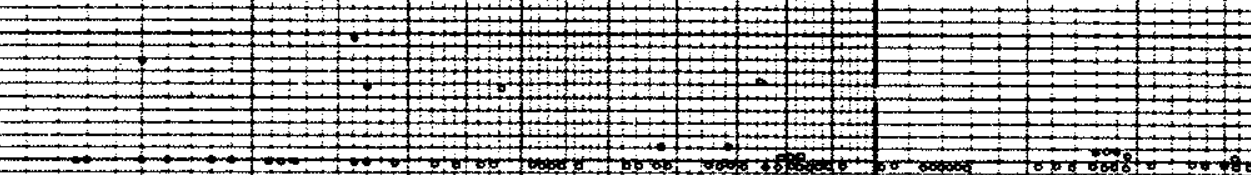

$=$

$1+1$

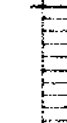

$50+$

$+$

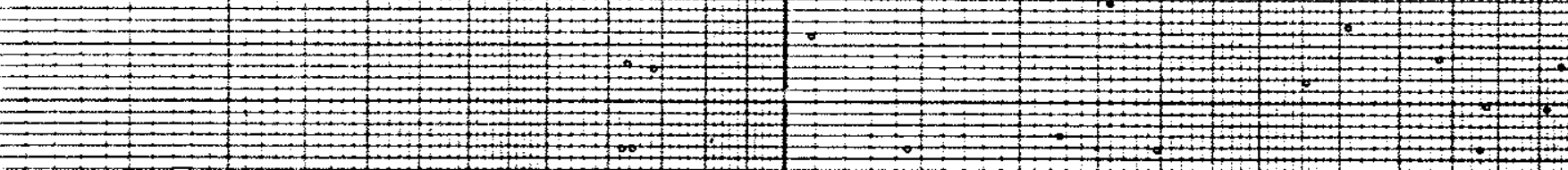

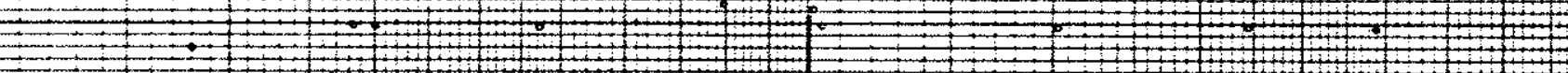

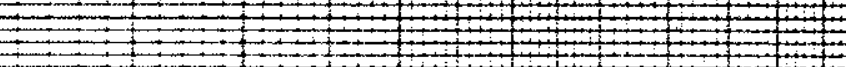

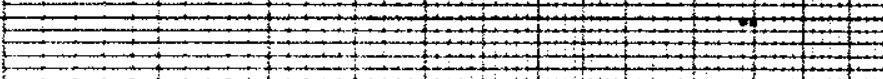

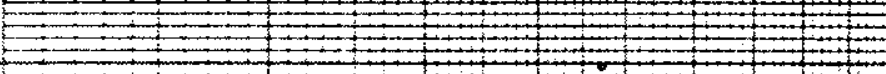

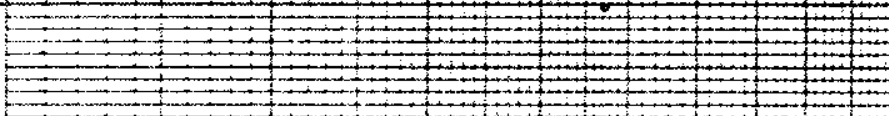

30

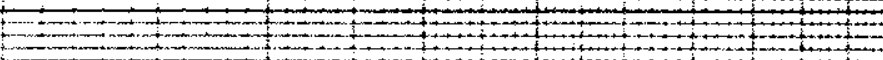

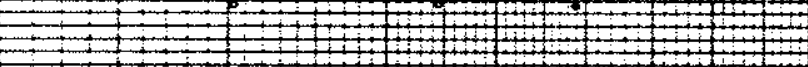

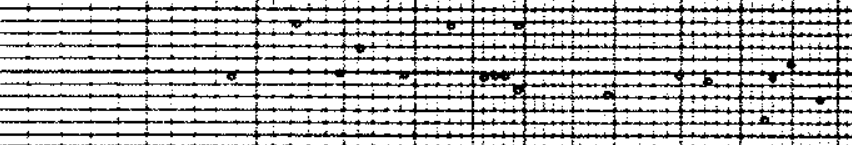

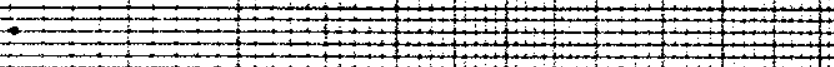

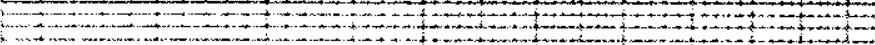

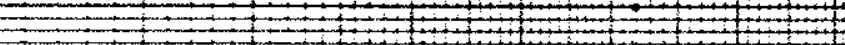

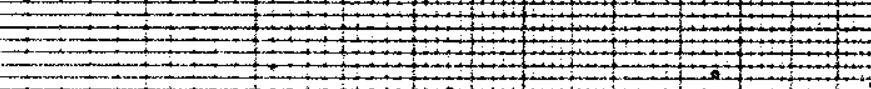

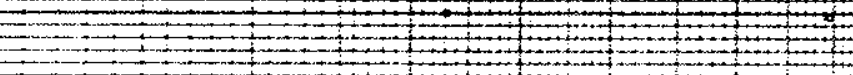

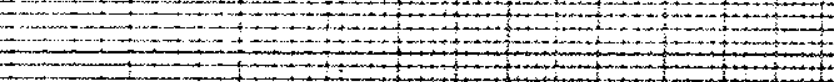

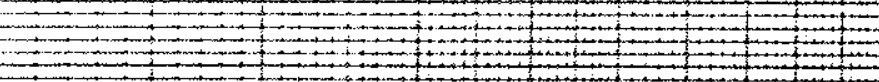

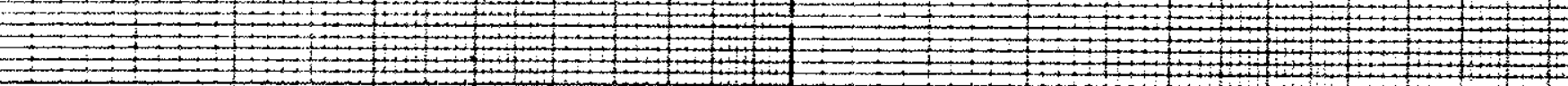


FIG. 7.4 - RELAÇĀO ENTRE PROFUNDIDAdE DE POÇO E VAZĀO ESPECÍFICA (REGIĀO ORIENTAL DA PARAIBA)

(m)

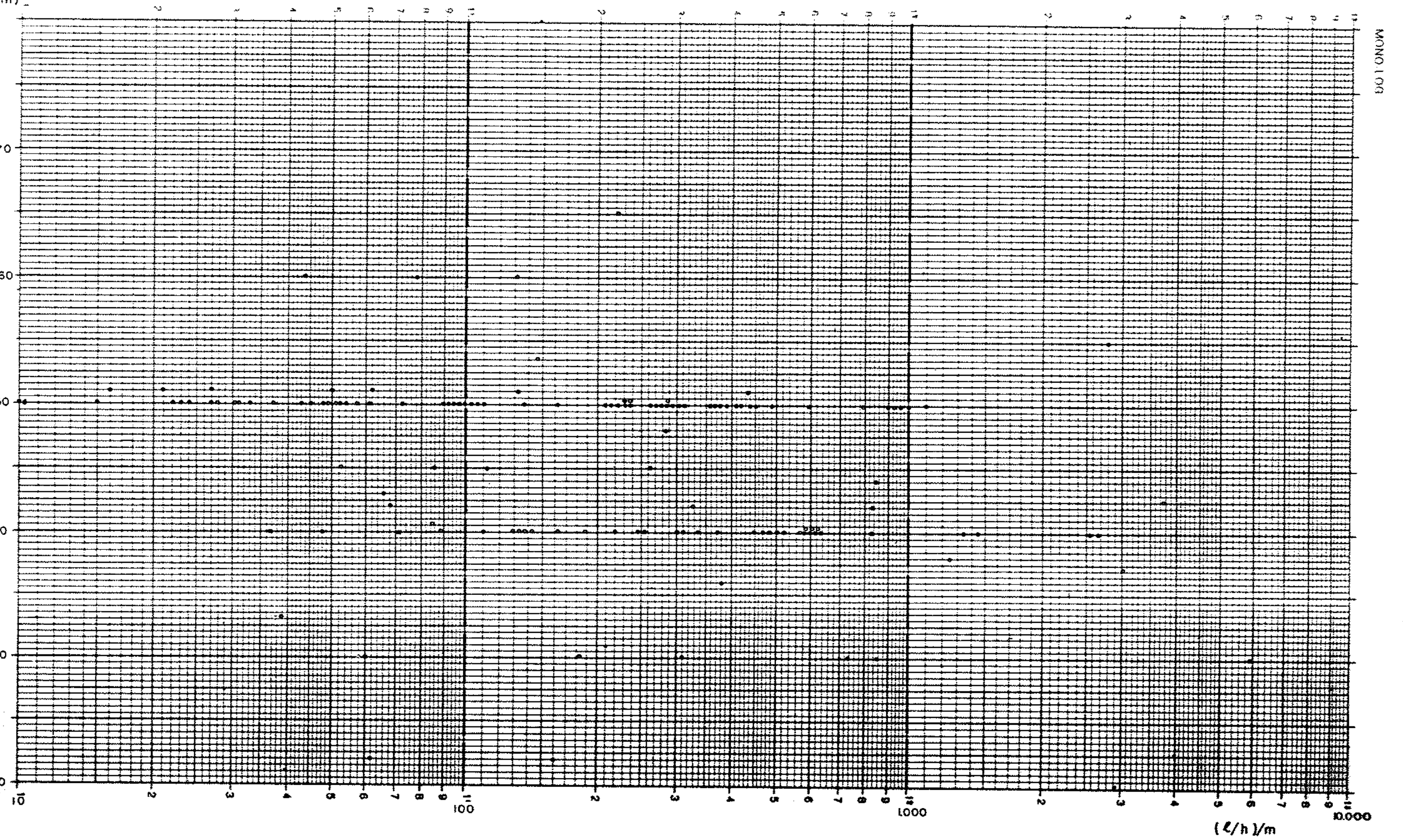


QUADRO 7.9 - CORRELAÇÃO ENTRE VAZAO ESPECIFICA E PROFUNDIDADE DO POÇO NA REGIAO ORIENTAL DO ESTADO DA PARAIBA

\begin{tabular}{|c|c|c|c|c|}
\hline & $X, Y$ & $\log X, \log Y$ & $\log X, Y$ & $X, \log Y$ \\
\hline MEDIA DA YARTAYEL DEPENDENTE & 443,81 & 2,279 & 443,81 & 2,279 \\
\hline MEDIA DA VARIAVEL INDEPENDENTE & 45,40 & 1,650 & 1,65 & $45,40.0$ \\
\hline DESVIO PADRAOO DA YARIÁYEL DEPENDENTE & 777,43 & 0,568 & 777,43 & 0,568 \\
\hline DESVIO PADRAO DA YARIAEVEL INDEPENDENTE & 7,40 & 0,080 & 0,08 & 7,400 \\
\hline VALOR DO COEFICIENTE $\bar{b}$ & $1.836,66$ & 5,838 & $5.292,28$ & 3,380 \\
\hline VALOR DO COEFICIENTE a & $-30,68$ & $-2,16$ & $-2.938,20$ & $-0,024$ \\
\hline COEFICIENTE DE CORRELAÇAO CRI & $-0,29$ & $-0,31$ & $-0,30$ & $-0,31$ \\
\hline
\end{tabular}


QUADRO 7.10 - RELAÇÃO DE FREQUENCIAS ENTRE PROFUNDIDADE DO POÇO E VAZĀO ESPECIFICA

\begin{tabular}{|c|c|c|c|c|c|c|c|}
\hline \multirow{3}{*}{$\begin{array}{l}\text { PROFUNDIDADE } \\
\mathrm{p}(\mathrm{m})\end{array}$} & \multicolumn{6}{|c|}{ VAZAO ESPECIFICA - Q/s } & \multirow{3}{*}{ TOTAL } \\
\hline & \multicolumn{2}{|c|}{$Q / s \leqslant 100$} & \multicolumn{2}{|c|}{$100<Q / s \leqslant 1000$} & \multicolumn{2}{|c|}{$Q / s>1000$} & \\
\hline & $n ?$ & $\frac{0}{9}$ & $\bar{n} \div$ & $\frac{0}{0}$ & n: & $\frac{\%}{\sigma}$ & \\
\hline$P \geqslant 60$ & 59 & 46,5 & 60 & 47,2 & 8 & 6,2 & 127 \\
\hline $40 \leqslant P<60$ & 13 & 18,6 & 41 & 58,6 & 16 & 22,8 & 70 \\
\hline$P<40$ & 1 & 5,0 & 11 & 55,0 & 8 & 40,0 & 20 \\
\hline & 73 & 33,6 & 112 & 51,6 & 32 & 14,7 & 217 \\
\hline
\end{tabular}

LOCAL: Região Oriental do Rio Grande do Norte 
QUADRO 7.11. RELAÇÃO DE FREQUENCIAS ENTRE PROFUNDIDADE DO POÇO E VAZAO ESPECIFICA

\begin{tabular}{|c|c|c|c|c|c|c|c|}
\hline \multirow{3}{*}{ PROFUNDIDADE } & \multicolumn{3}{|c|}{ VAZAO ESPECIFICA } & \multicolumn{3}{|c|}{$(1 / h) / m$} & \multirow{3}{*}{ TOTAL } \\
\hline & \multicolumn{2}{|c|}{$\mathrm{Q} / \mathrm{s}<100$} & \multicolumn{2}{|c|}{$100<Q / s<1.000$} & \multicolumn{2}{|c|}{$\mathrm{Q} / \mathrm{s}>1.000$} & \\
\hline & $n^{\circ}$ & $\%$ & $n^{\circ}$ & $\%$ & $n^{\circ}$ & $\%$ & \\
\hline$P \geqslant 50$ & 34 & 44,7 & 40 & 52,6 & 2 & 2,6 & 76 \\
\hline $40 \leqslant p<50$ & 9 & 18,7 & 34 & 70,8 & 5 & 10,4 & 48 \\
\hline$P<40$ & 3 & 23,1 & 6 & 46,1 & 4 & 30,8 & 13 \\
\hline & 46 & 33,6 & 80 & 58,4 & 11 & 8,0 & 137 \\
\hline
\end{tabular}

LOCAL: Região Oriental da Paraiba 
ção entre si. O estudo ficcou mais completo com os dados da CDMRN pelo maior nümero de fraturas registradas por poço (em mëdia 3,5 fratura/poço), enquanto os dados da CDRM-PB apresentam em me dia 1,07 fratura/poço. Apesar da vazão especî́fica na região ocidental ser, em mëdia, apenas $65^{\circ}$ da vazão específica média da região oriental, os dados de fratura acusam,praticamente, o mesmo resultado para essas duas regiões (verquadro 7.12). A maior inci dência de fraturas, em ambos os Estados, é na faixa de profundidade de 10 a $20 \mathrm{~m}$, com cêrca de $40 \%$ das quase 2.000 fraturas medidas. A partir dos $20 \mathrm{~m}$ de profundidade, vai diminuindo o percen tual para $22 \%$ na faixa de 20 a $30 \mathrm{~m}$, para $11 \%$ na faixa de 30 e 40 metros, para $5,5 \%$ na faixa de 40 a $50 \mathrm{~m}$, e finalmente para $3 \%$ nas profundidades superiores a $50 \mathrm{~m}$. A diminuição é em torno de $50 \%$ de uma faixa para outra.

Sumarizando em faixas de $20 \mathrm{~m}$, têm-se o seguinte resultado :

$\begin{array}{rrrr}\text { Prof. } & \text { PB } & \text { RN } & \text { Total. } \\ 0-20 \mathrm{~m} & 52,2 \% & 59,3 \% & 57,8 \% \\ 20-40 \mathrm{~m} & 40,8 \% & 31,7 \% & 33,7 \% \\ >40 \mathrm{~m} & 7,0 \% & 9,0 \% & 8,5 \%\end{array}$

Esses resultados, aliados àqueles obtidos nas relaçōes Va zão Especîfica $x$ Profundidade total do poço, pernitem concluir que a profundidade limite, que deveria ser adotada para poços em aqui feros fissurais, no nordeste do Brasil, seria de $40 \mathrm{~m}$, excepcionalmente podendo ir atê os $50 \mathrm{~m}$.

\subsubsection{RELAÇAO VAZÃO ESPECIFICA X MANTO DE COBERTURA}

O manto de cobertura pode se constituir em importante fator de recarga do aquifere fissural quando possui boa espessura e $\vec{e}$ constituído, predominantemente, de material psamitico, pobre em pelitos.

Na região, foi procedida uma amostragem, escolhendo-se os poços das bacias orientais do R.G. do Norte, num total de 228 , e os poços da bacia do Piranhas (região ocidental) do mesmo Estado, em número de 115. A escolha das duas regiões deveu-se ao fato de 
QUADRO 7.12 - FREQUENCIA DE FRATURAS POR PROFUNDIDADES(POR ESTADO E POR REGIAO)

\begin{tabular}{|c|c|c|c|c|c|c|c|}
\hline \multirow{2}{*}{$\begin{array}{l}\text { PROFUNDI } \\
\text { DADE (m) }\end{array}$} & \multicolumn{3}{|c|}{$\mathrm{P} A \mathrm{~A} A \mathrm{~A}$ I B A } & \multicolumn{3}{|c|}{ R. G. D O NOR T E } & \multirow{2}{*}{$\begin{array}{l}\text { TOTAL } \\
\text { GERAL }\end{array}$} \\
\hline & ORIENTAL & OCIDENTAL & TOTAL & ORIENTAL & OCIDENTAL & TOTAL & \\
\hline $0-10$ & $12(8,1 \%)$ & $20(7,1 \%)$ & $32(7,5 \%)$ & $150(20,0 \%)$ & $192(23,7 \%)$ & $342(21,9 \%)$ & $374(18,8 \%)$ \\
\hline $10-20$ & $68(45,9 \%)$ & $124(44,1 \%)$ & $192(44,8 \%)$ & $280(37,3 \%)$ & $303(37,5 \%)$ & $583(37,4 \%)$ & $775(39,0 \%)$ \\
\hline $20-30$ & $43(29,1 \%)$ & $72(25,6 \%)$ & $115(26,8 \%)$ & $172(22,9 \%)$ & $161(19,9 \%)$ & $333(21,4 \%)$ & $448(22,5 \%)$ \\
\hline $30-40$ & $19(12,8 \%)$ & $41(14,6 \%)$ & $60(14,0 \%)$ & $69(9,2 \%)$ & $92(11,4 \%)$ & $161(10,3 \%)$ & $221\left(11,1 \frac{\circ}{0}\right)$ \\
\hline $40-50$ & $3(2,0 \%)$ & $22(7,8 \%)$ & $25(5,8 \%)$ & $52(6,9 \%)$ & $33(4,1 \%)$ & $85(5,5 \%)$ & $110(5,5 \%)$ \\
\hline 50 & $3(2,0 \%)$ & $2(0,8 \%)$ & $5(1,2 \%)$ & $27(3,6 \%)$ & $28(3,5 \%)$ & $55(-3,5 \%)$ & $60(3,0 \%)$ \\
\hline Nofrat. & 148 & 281 & 429 & 750 & 809 & 1559 & 1988 \\
\hline Nopoços & 144 & 256 & 400 & 228 & 215 & 443 & 843 \\
\hline$N \odot f / N \circ p$ & 1 & 1,1 & 1,07 & 3,3 & 3,8 & 3,5 & 2,4 \\
\hline
\end{tabular}


na primeira predominarem maiores espessuras de capeamento do que na segunda.

Foi tentado estabelecer uma relação geométrica (linear ou não), plotando-se em papel mono-log as espessuras de capeamento, contra as vazões específicas (ver Fig. 7.5. e 7.6). Como pode ser visto nos respectivos desenhos, a distribuição dos pontos foi com pletamente aleatöria, não podendo ser utilizada nenhuma relação estatistica entre os referidos parâmetros. A "nuvem de pontos"dis tribuiu-se quase uniformemente, com nítida predominância abaixo dos $5 \mathrm{~m}$ de espessura. Executada a análise de regressão entre essas variāveis para a região de maiores espessuras de:manto, o resulta do revelou (Quadro 7.13).inexistência de correlação entre as vari âveis. O baixo indice ora mostra uma relação direta, ora inversa.

o gräfico revela entretanto que, na região oriental, apenas $29 \%$ dos poços possuem espessura de capeamento igual ou superior a $5 \mathrm{~m}$, enquanto na região ocidental, essa percentagem cai para $21,4 \%$. Dos poços com mais de $5 \mathrm{~m}$ de capeamento, $28,5 \%$ na região orienta 1 e 48\% na ocidental, possuem vazöes especîficas inferiores a $100 \mathrm{l} / \mathrm{h} / \mathrm{m}$ e para as duas regiōes, $70 \%$ dos poços com capeamento superior a $5 \mathrm{~m}$ fornecem vazões especificas inferiores a $500(\mathrm{l} / \mathrm{h} / \mathrm{m}$. Nos poços com a vazão específica superior a $1000(1 / \mathrm{h} / \mathrm{m}, 70 \%$ têm capeamento inferior a $5 \mathrm{~m}$ e apenas $30 \%$ possuem mais de $5 \mathrm{~m}$.

Desses dados se conclui que, na regiäo de estudo, o manto de cobertura apresenta uma relação inversa com a vazão específica, ou seja, os poços com maior espessura de capeamento, tendem a apresentar menores vazões específicas.

Essa relação aparentemente anômala, pode ser facilmente compreendida, face às seguintes razões:

$\left.1^{\circ}\right)$ as espessuras do capeamento säo em geral reduzidas, com o máximo valor apresentado, de $19 \mathrm{~m}$ no R.G.do Norte, e $12 \mathrm{~m}$ na Paraíba; as mëdias nesses dois Estados são respectivamente $3,85 \mathrm{~m}$ e $2,42 \mathrm{~m}$, com coeficientes de variação respectivos de $78,9 \%$ e $79,1 \%$ Foi mostrado que, mesmo nas bacias orientais do R.G. do Norte, on de as espessuras alcançam maiores valores, apenas $29,4 \%$ dos poços tiveram espessuras de capeamento superiores a $5 \mathrm{~m}$.

$\left.2^{\circ}\right)$ as precipitaçőes pluviomêtricas näo são abundantes pa ra promoverem uma realimentação contínua e eficaz desse manto;por outro lado, a evaporação ể intensa e, nos mantos de espessura in- 
FIG.7.5 - RELAÇĀO ENTRE A VAZĀO ESPECÍFICA E A ESPESSURA DE CAPEAMENTO (REGIĀO ORIENTAL DO RIO G. DO NORTE)

(m)

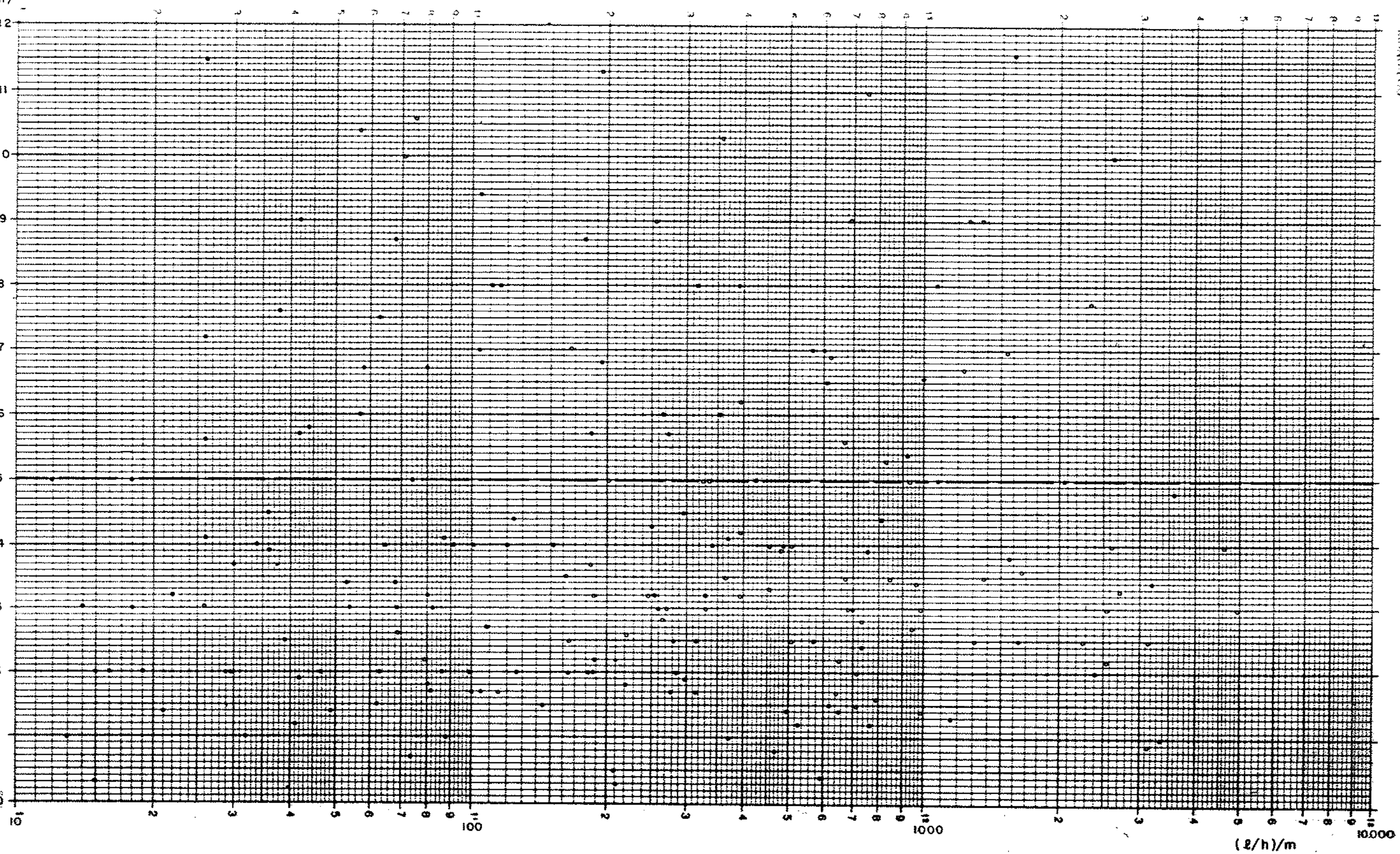


FIG. 7.6 - RELAÇĀO ENTRE A VAZĀO ESPECIFICA E A ESPESSURA DE CAPEAMENTO (REGIĀO CENTRO-SUL DO RIO G. DO NORTE)

$(\mathrm{m})$

125

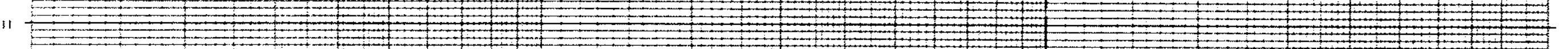

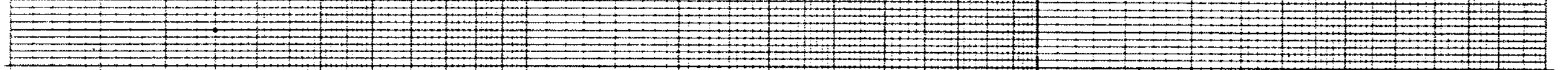

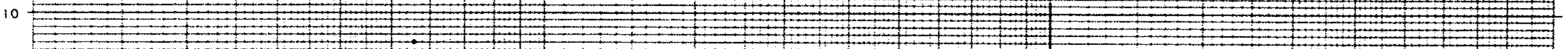

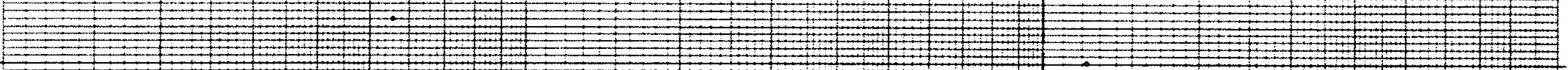

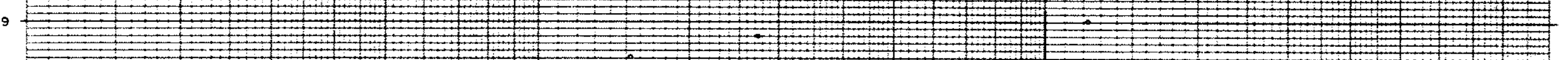

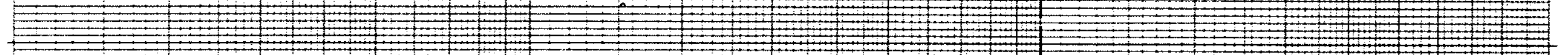

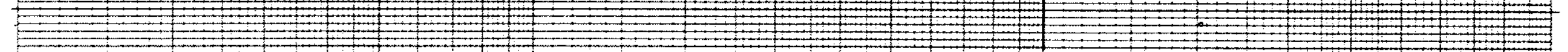

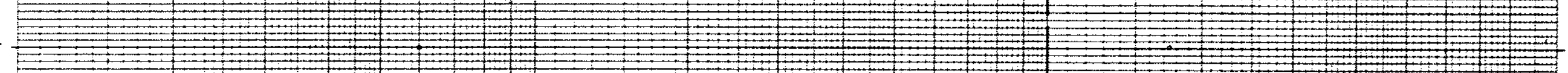

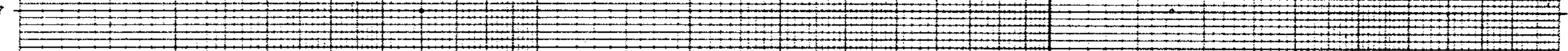

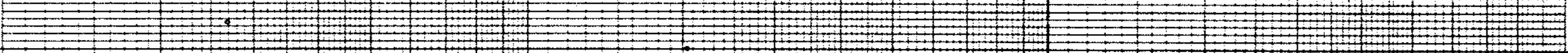

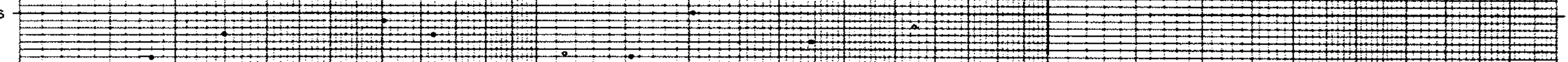

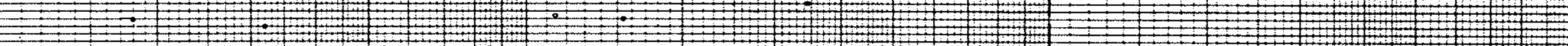
$20 \ldots 1+1 \ldots$

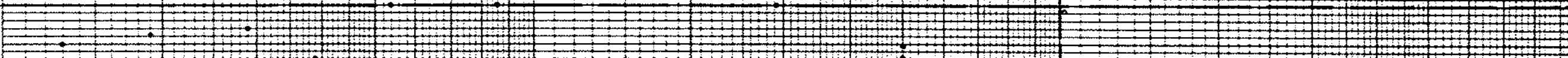

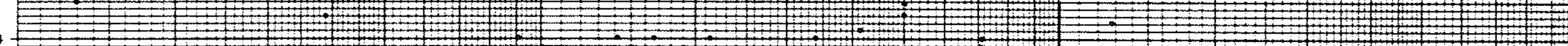

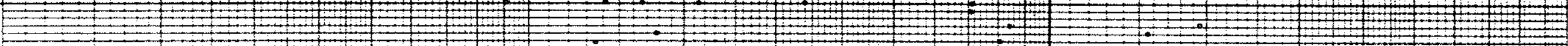

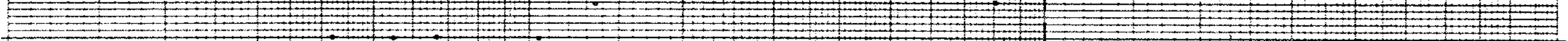

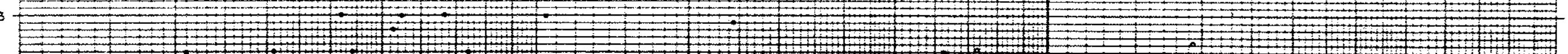

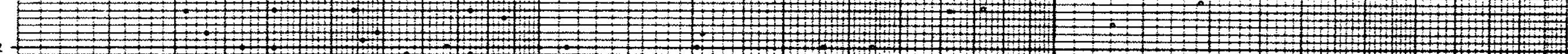
$51+1+1+1+1+1+1$

1

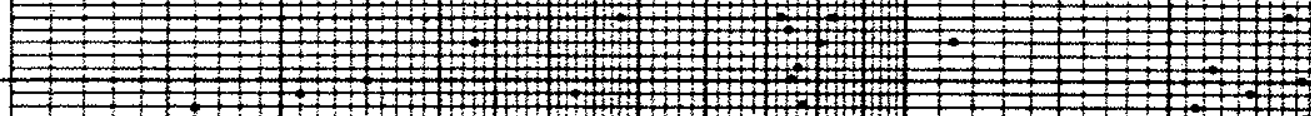

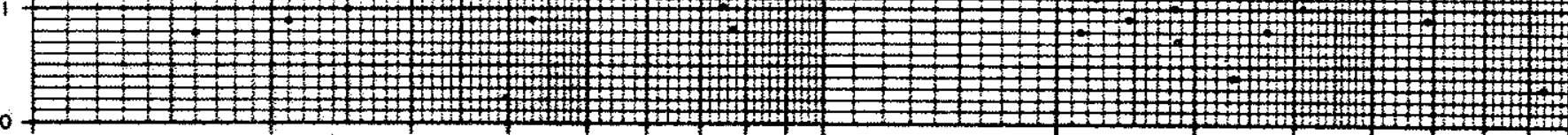
$\frac{7}{10}$ is $+2010$ $2+2+2$ LI

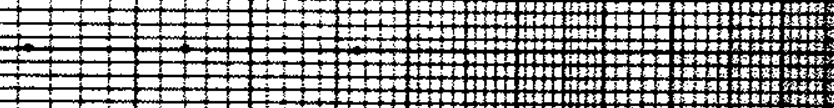

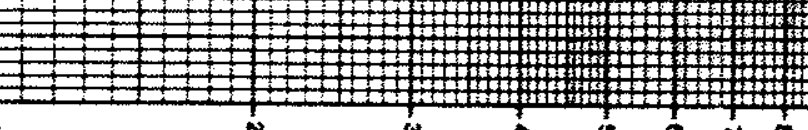
100 
QUADRO 7.13 - CORRELAÇÃO ENTRE A YAZÃO ESPECIFICA E O MANTO DE COBERTURA NA REGIAO ORIENTAL DO ESTADO DO RIO GRANDE DO NORTE

\begin{tabular}{|c|c|c|c|c|}
\hline ' & $X, Y$ & $\log X, \log X$ & $\log X, Y$ & $X, \log Y$ \\
\hline MEDIA DA VARIAYEL DEPENDENTE & 761,32 & 2,347 & 761,32 & 2,347 \\
\hline MEDIA DA YARIĀYEL INDEPENDENTE & $4,2.2$ & $0,5.21$ & 0,52 & 4,225 \\
\hline DESVIO PADRAO DA YARIAYEL DEPENDENTE & $1.948,30$ & 0,696 & $1.248,30$ & $a, 6.96$ \\
\hline DESUIO PADRAO DA YARIAYEL INDEPENDENTE & 3,38 & 0,321 & a., 32 . & 3,385 \\
\hline VALOR DO COEFICIENTE & $840,6.4$ & 2,262 & $793,7 a$ & 2,300 \\
\hline VALOR DO COEFICIENTE a & $-18,46$ & 0,163 & $-62,21$ & 0,109 \\
\hline COEFICIENTE DE CORRELAÇAO (RI & $-0,032$ & 0,075 & $-0,010$ & $0,0.53$ \\
\hline
\end{tabular}


ferior a 3m (mëdia geral da região) o efeito da evaporação se faz sentir com grande intensidade.

$\left.3^{\circ}\right)$ a constituição granulomêtrica ể mais pelítica que psa mítica, conforme jä abordado aträs. No Estado do R.G. do Norte o teor de areias chega, em mëdia, a $32 \%$ e na Paraíba a apenas 18\%, sendo o restante do material constituido de argilas puras (da ordem de $12 \%$ em ambos os Estados) e misturas de areias, si1tes e argi.1.as em proporções variadas.

4i) a locação do poço realizada com base em critêrios têc nicos, sobretudo na relação hidrografia-estrutura, comumente conhe cida como riacho-fenda, fica prejudicada nas regiỏes com maiores espessuras de capeamento, pois as estruturas ficam "mascaradas" pe 1o material de cobertura, que dificulta e at $\vec{e}$ impede ( a depender da espessura do manto) o aparecimento do afloramento rochoso.

Se for efetuada uma comparação das vazões dos poços da re gião em estudo, com outras no sul do paîs, verifica-se que em algumas regiões sulistas as vazões são bem maiores, atë 10 vezes em mëdia, sendo a causa principal a espessa cobertura de material arenoso com 40 a $50 \mathrm{~m}$ de possança, aliado a uma precipitação pluvi ométrica da ordem de $2.000 \mathrm{~mm} /$ ano e baixos valores de evaporação( que não teria influência para grandes espessuras de sedimentos).

\subsubsection{RELAÇAO VAZÃO ESPECIFICA X RELEVO/HTDROGRAFIA}

Igualmente ao estudo da relação. Vazão Especifica $x$ Tipo de Fratura, essa relação foi executada na ärea do Projeto Scheeli. ta, com os mesmos dados que serviram ao estudo anterior.

Como pode ser constatado, pela anảlise do Quadro 7.14, a situação mais favorävel ë aquela em que o poço se situa no talvegue, com vazão espectfica mëdia de $458,7(\mathrm{l} / \mathrm{h} / \mathrm{m}$, seguida pela loca çäo na encosta, com vazão específica mëdia de $348,1 \mathrm{l} / \mathrm{h} / \mathrm{m}$, e , por ültimo, como mais desfavorảve1, no topo das elevações, com vazão específica mêdia de 162,7 (1/h/h $/$. O valor mëdio da vazão dos poços localizados nas encostas corresponde a $75,9 \%$ do valor mëdio dos poços situados no talvegue, enquanto no topo das elevações, o valor mêdio da vazão corresponde a apenas $35,5 \%$ da situação do talvegue. 
QUADRO 7.14 - VALORES DE VAZRO ESPECIFICA PARA CADA SITUAÇAO DE RELEVO

\begin{tabular}{|c|c|c|c|c|c|c|c|c|c|c|}
\hline \multirow{2}{*}{$\begin{array}{l}\text { LOCAÇAO QUANTO } \\
\text { AO RELEVO }\end{array}$} & \multirow[b]{2}{*}{ VALOR } & \multicolumn{3}{|c|}{ RIO GRANDE DO NORTE } & \multicolumn{3}{|c|}{ PARAIBA } & \multicolumn{3}{|c|}{ TOTAL } \\
\hline & & $(1 / h) / m$ & $N^{\circ}$ & $\frac{\circ}{8}$ & $(1 / h / m$ & $N^{\circ}$ & $\%$ & $(1 / \mathrm{h} / \mathrm{m}$ & $\mathrm{N}^{\circ}$ & $\%$ \\
\hline No talvegue & $\begin{array}{l}\text { MAXIMO } \\
\text { MINIMO } \\
\text { MEDIO }\end{array}$ & $\begin{array}{r}8.034 \\
16 \\
478 \\
\end{array}$ & 95 & 64,2 & $\begin{array}{r}3.714 \\
10 \\
435\end{array}$ & 77 & 72,6 & $\begin{array}{r}8.034 \\
10 \\
459\end{array}$ & 172 & 67,7 \\
\hline $\mathrm{Na}$ encosta & $\begin{array}{l}\text { MAXIMO } \\
\text { MINIMO } \\
\text { MEDIO }\end{array}$ & $\begin{array}{r}2.045 \\
13 \\
386 \\
\end{array}$ & 28 & 18,9 & $\begin{array}{r}2.653 \\
12 \\
302 \\
\end{array}$ & 23 & 21,7 & $\begin{array}{r}2.045 \\
12 \\
348 \\
\end{array}$ & 51 & 20,1 \\
\hline $\mathrm{Na}$ elevação & $\begin{array}{l}\text { MAXIMO } \\
\text { MINIMO } \\
\text { MEDIO }\end{array}$ & $\begin{array}{r}1.310 \\
14 \\
183\end{array}$ & 25 & 16,9 & $\begin{array}{r}143 \\
33 \\
78\end{array}$ & 6 & 5,7 & $\begin{array}{r}1.310 \\
14 \\
163\end{array}$ & 31 & 12,2 \\
\hline MEDIA e TOTAL & & 411 & 148 & & 386 & 106 & & 400 & 254 & \\
\hline
\end{tabular}


Deve ser ressaltado, que os poços localizados nas encostas, são em geral, à pequena distância do talvegue, o que justifica a vazão especîfica mëdia ficar bem pröxima da dos localizados no próprio talvegue.

Por outro 1ado, deve ser lembrado que para cada situação de relevo analisado, intervém também os outros fatores, que in fluem em maior ou menor escala, na produçäo p̉otencial do poço.

Evidentemente, a participação do binômio relevo/hidrografia $\vec{e}$ de fundamental importância, pois se a rocha for fraturada e não houver uma alimentação eficaz por infiltração de äguas superficiais, o poço pode atê. mesmo ser completamente seco. Já foi men cionado aträs, a existência de vários poços secos na ärea, onde a perfuratriz atravessa värias fendas sem ägua.

0 estilo tectônico ruptural dominante no nordeste, ë o de Eraturas sub-verticais, que ocorrem em proposiçäo superior a $80 \%$ com relação às inclinadas. As fraturas atectônicas, decorrentes do alivio de pressão ("sheet structure") não desempenham quase ne nhuma importância, devido a pouca profundidade que alcançam ( em geral não ultrapassam $10 \mathrm{~m}$ ). Assim, quanto mais próximo do ta1vegue, mormente nos trechos retilineos da drenagem, em que ocorre um controle estrutural do curso d'ägua, maiores serão as possibilidades de se obter melhor vazão.

O resultado dessa análise corresponde aproximadamente àque les realizados em outros paises, principalmente os apresentados por LEGRAND (1950) 'nas äreas de Carolina do Norte, Pittsylvania e Halifax e SEVER (1964) em Dawson, Georgia. Legrand trabalhou com 700 poços e caracterizou 5 (cinco) situações de relevo, na maior parte associado à hidrografia: topo de colinas, vertentes de vales, depressões de bacias principais, depressões (talvegues) de vales secundärios e planícies. A melhor situação foi a de depressões de bacias principais, sendo a relação das demais situações para esta mais favorävel, a seguinte: na planîcie e vales secundá rios, $83,5 \%$ e $75 \%$ respectivamente (essas situações não foram analisadas no estudo); entre o topo e a depressão a relação varia de uma região estudada para outra, desde $16,8 \%$ na Pittsylvania e Halifax ate $42,7 \%$ na Carolina do Norte; finalmente entre a encosta e a depressão, a relação $\vec{e}$ da ordem de $53,4 \%$, bem inferior portan to ãquela encontrada na pesquisa ora encetada. 
A pesquisa de Sever, abrangeu apenas 50 poços, localizados somente em duas situações distintas: topo e flanco da elevação. A relação entre os mesmos ê que no topo as vazões variaram desde $66,6 \%$ atê $83,5 \%$ das vazões dos flancos.

o resultado geral das três pesquisas confere ãs depressões morfolögicas, onde se localizam cursos d'ägua, a melhor situação hidrogeolögica, seguida dos flancos ou encostas dos vales e por ültimo o topo das elevações, ou divisores hidrogräficos.

\subsubsection{RELAÇAO VAZAO ESPECIFICA X CLTMA}

o clima exerce uma moderada participação na potencialidade de um aquífero, como foi visto no Capítulo 2 , pois na medida que a precipitação ê mais intensa, maior serâ a infiltração $e$, consequentemente, maiores as vazões.

Foi visto no Quadro 6.5 que as vazões especificas mêdias, por regiäo e Estado, eram as seguintes, em $(1 / \mathrm{h}) / \mathrm{m}$ :

$\begin{array}{lccc} & \text { R.G.do Norte } & \text { Paräba } & \because R N+P B \\ \text { Região Oriental } & 775,25 & 401,52 & 626,18 \\ \text { Região Ocidental } & 525,92 & 315,57 & 411,06\end{array}$

Observa-se que, de um modo geral, a regiäo oriental; é possuidora de vazões específicas maiores (cerca de $50 \%$ a mais) do que a região ocidental. Na realidade, a região oriental, à exceção das cabeceiras dos cursos, que se situa na dorsal semi-árida da Borborema, possui mais elevados indices de pluviosidade, inclusive propiciando a perenização do baixo curso de quase todos os rios da região; enquanto isso, ocorre o conträrio na região oci dental, que ê mais "chovida" nas cabeceiras das bacias, tornandose as precipitações mais rarefeitas no baixo curso.

Evidentemente, outros fatores influem na produção potenci al de um poço, inclusive a metodologia de perfuração e desenvolvi mento empregados. Assim ê que, a precipitação por si somente, não justifica as melhores vazöes obtidas no Estado do R.G. do Norte, que possui vazões de $67 \%$ a $93 \%$ superiores às da Paraíba, nas regiões ocidental e oriental, respectivamente. 


\subsubsection{RELAÇAO RESIDUO SECO X TIPO DE ROCHA}

A análise da correlação entre o resíduo seco e o tipo de rocha, foi desenvolvida separadamente, por região de cada Estado, de vez que, foram constatadas sensíveis diferenças de uma região para outra e de um Estado para outro.

Para cada tipo de rocha e de cada região e Estado, foi calculada a mêdia, o desvio padrão e o coeficiente de variação, sendo os resultados encontrados nos Quadros 7.15 e 7.16 .

Em todos os tipos de rochas, nos dois Estados, pode-se constatar a grande diferença entre o resîduo seco da região orien tal para a ocidental. Em termos mëdios, o resî́duo seco das äguas de poços localizados na região ocidental, corresponde a apenas $26 \%$ do resîduo seco da região orienta1. Tambêm de um Estado para outro, hä sensiveis diferenças, sendo em termos mêdios gerais, o resîduo seco das äguas de poços do Estado da Paraíba corresponden te a $72:$ do resîduo seco no Rio Grande do Norte.

Devido a essas diferenças regionais, não se pode analisar a participação mểia global de cada tipo de rocha, e sim por região e Estado, como aparece nos Quadros 7.15 e 7.16 .

$\mathrm{Na}$ Paraíba, o gnaisse, o micaxisto, o granito e o migmati to apresentam quase a mesma média na região oriental (em torno de $4.500 \mathrm{mg} / 1$ ) porêm varia bastante na região ocidental, onde o mica xisto aparece como portador das ăguas mais salinizadas, seguindose do gnaisse, do migmatito e do granito. Em menor grau de salini zação, aparecem as águas do quartzito e do filito.

No Rio Grande do Norte o micaxisto apresenta as äguas mais salinizadas na região oriental (mêdia de $8.450 \mathrm{mg} / 1$ ), sendo porëm pouco representativa a mëdia devido ao pequeno nümero de amostras (apenas 6); o mesmo ocorre com os migmatitos com sete amostras ( mêdia de $7.830 \mathrm{mg} / 1$ ) e que vêm logo a seguir aos micaxistos. Os va lores mais representativos são os dos gnaisses, na região oriental com 167 maostras (mëdia de $6.030 \mathrm{mg} / 1$ ) e na região ocidental com: 102 amostras (mëdia de $1.930 \mathrm{mg} / 1$ ). De um modo geral, não ocorrem sensiveis diferenças entre os vârios tipos de rochas, a não ser nos quartzitos, com mëdia inferior a $1.000 \mathrm{mg} / 1$. 
QUADRO 7.15 - RELAÇAO RESIDUO SECO X TIPO DE ROCHA NO ESTADO DO RIO GRANDE DO NORTE

\begin{tabular}{|c|c|c|c|c|c|}
\hline ROCHA & REGIAO & $\overline{\mathrm{X}}(\mathrm{mg} / \mathrm{I})$ & $\sigma(\mathrm{mg} / 1)$ & C.V. $(\%)$ & N:AMOST. \\
\hline \multirow{2}{*}{ GNAISSE } & ORIENTAL & $6.036,95$ & $5.302,80$ & 87,95 & 167 \\
\hline & OCIDENTAL & $1.927,49$ & $2.472,51$ & 128,28 & 102 \\
\hline \multirow{2}{*}{ GRANITO } & ORIENTAL & $6.462,59$ & $5.500,38$ & 85,11 & 15 \\
\hline & OCIDENTAL & $1.471,19$ & $1.402,78$ & 95,35 & 38 \\
\hline \multirow{2}{*}{ MICAXISTO } & ORTENTAL & $8.453,90$ & $5.249,11$ & 62,09 & 6 \\
\hline & OCIDENTAL & $1.976,26$ & $1.520,66$ & 76,95 & 34 \\
\hline \multirow{2}{*}{ MIGMATITO } & ORIENTAL & $7.835,83$ & $5.807,22$ & 74,11 & 7 \\
\hline & OCIDENTAL & $2.489,91$ & $2.235,07$ & 117,88 & 7 \\
\hline \multirow{2}{*}{ QUARTZITO } & ORIENTAL & r & $*$ & - & - \\
\hline & OCIDENTAL & 833,31 & 247,91 & 29,75 & 7 \\
\hline TODAS AS RO & ORIENTAL & $6.208,63$ & $5.340,44$ & 86,00 & 125 \\
\hline CHAS JUNTAS & OCIDENTAL & $1.731,57$ & $2.018,54$ & 116,57 & 188 \\
\hline
\end{tabular}


QUADRO 7.16 - RELAÇAO RES IDUO SECO $\times$ TIPO DE ROCHA NO ESTADO DA PARAIBA

\begin{tabular}{|c|c|c|c|c|c|}
\hline ROCHA & REGIAO & $\overline{\mathrm{X}}(\mathrm{mg} / \mathrm{I})$ & $\sigma(\mathrm{mg} / 1)$ & C.V. $(\because)$ & N:AMOSTRA \\
\hline \multirow{2}{*}{ GNAISSE } & ORIENTAL & $4.781,83$ & $4.262,89$ & 89,15 & 10.3 \\
\hline & OCIDENTAL & 1. 328,78 & $1.742,52$ & 131,20 & 120 \\
\hline \multirow{2}{*}{ MICAXISTO } & ORIENTAL & $4.737,48$ & $3.586,71$ & 75,71 & 10. \\
\hline & OCIDENTAL & $1.752,47$ & $2.123,21$ & 121,16 & 32 \\
\hline \multirow{2}{*}{ GRANITO } & ORIENTAL & $4.49 .3,9.1$ & $2.484,08$ & 55,28 & 13 \\
\hline & OCIDENTAL & 885,50 & 577,68 & 65,24 & 29 \\
\hline \multirow{2}{*}{ MIGMATITO } & ORIENTAL & $3,936,50$ & $2.211,69$ & 56,18 & 10 \\
\hline & OCTDENTAL & 922,45 & 792,63 & 72,87 & 16 \\
\hline \multirow{2}{*}{ FFLETO } & ORIENTAL & $=$ & - & - & $=$ \\
\hline & OCIDENTAL & $60.9,46$ & $246,0.8$ & 40,38 & 39 \\
\hline \multirow{2}{*}{ QUARTZETO } & ORIENTAL & - & $=$ & - & $=$ \\
\hline & OCTDENTAL & $1.160,70$ & 778,12 & $6.7,0.4$ & 7 \\
\hline \multirow{2}{*}{$\begin{array}{l}\text { TODAS AS RO } \\
\text { CHAS WUNTAS }\end{array}$} & ORIENTAL & $4.688,88$ & $3.822,60$ & 83,00 & 136 \\
\hline & OCIDENTAL & $1.205,00$ & $1.345,54$ & 111,66 & 250 \\
\hline
\end{tabular}


Pelo exposto, a influência do tipo de rocha $\vec{e}$ muito baixo, nos processos de salinizaçäo, desde que, näo ocorre um tipo lítico que se sobressaia em todas as regiōes. Apesar disso, podemse veri. ficar que algumas rochas como o micaxisto, aparecem sempre com in dices dos mais elevados, enquanto outras, como o quartzito, ofere cem sempre os valores mais baixos.

A razão desses fatos pode ser explicada à 1 uz das caracte rísticas físicas e composição mineral da rocha, conforme já anaili sado atrâs. Assim, o micaxisto que tem maior energia de deformação e mais baixo môdulo de elasticidade, possui as fraturas mais fechadas (embora que em menor nümero) do que os gnaisses, granitos e migmatitos. Essa caracteristica acarreta uma menor circulação e renovação d'ägua, provocando, em consequência, um aumento de salinizaçäo. Măo quartzito, alëm de ter características físicas favo rảveis â circulação, a sua composição exclusiva de quartzo não acarreta qualquer salinização em decorrência de dissolução mineral da rocha, como pode acontecer com outras rochas pluriminerälicas, com minerais mais instâveis.

Alêm disso, deve ser considerado, que, superpondo-se a influência da rocha, existem outros fatores endögenos e exögenos. Assim, por exemplo, os filitos, por serem as rochas de menor aber tura de fraturamento, deveriam ter as äguas mais salinizadas, entretanto, essas rochas situam-se na bacia hidrogräfica do Rio Pian có, cujas águas são de excelente qualidade; logo ao se infiltrarem, as âguas jâ são desprovidas de sais, o que beneficia a quali dade da ägua armazenada nas fraturas.

7.2.10. RELAÇAO RESTDUO SECO X TIPO DE FRATURA

Para o relacionamento desses dois elementos, foi mais uma vez utilizada a amostragem da ägua do projeto Scheelita, e adotada a mesma classificação de fraturas jâa vista aträs.

Conforme pode ser visto no Quadro 7.17 , dos 232 poços com anälise química, as fraturas longitudinais de cisalhamento, com a penas $6,5 \%$ de participação, acarretam as mais elevadas taxas de salinização, com a mëdia de $5.072 \mathrm{mg} / 1$. 
QUADRO 7.17 - VALORES DE RESIDUO SECO POR TIPO DE FRATURA

\begin{tabular}{|c|c|c|c|c|c|c|c|c|c|c|}
\hline \multirow{2}{*}{$\begin{array}{l}\text { TIPO DE } \\
\text { FRATURA }\end{array}$} & \multirow[b]{2}{*}{ VALOR } & \multicolumn{3}{|c|}{ RIO GRANDE DO NORTE } & \multicolumn{3}{|c|}{ PARAIBA } & \multicolumn{3}{|c|}{ TOTAL } \\
\hline & & $\mathrm{mg} / \mathrm{I}$ & N: & $\%$ & $\mathrm{mg} / 1$ & No & $\%$ & $\mathrm{mg} / 1$ & No & $\frac{\%}{0}$ \\
\hline $\begin{array}{l}\text { Longitudinal } \\
\text { tracional }\end{array}$ & $\begin{array}{l}\text { MEXIMO } \\
\text { MPNIMO } \\
\text { MEDTO }\end{array}$ & $\begin{array}{r}5.260 \\
352 \\
1.558 \\
\end{array}$ & 7 & 5,2 & $\begin{array}{l}6.240 \\
1.150 \\
3.147 \\
\end{array}$ & 3 & 3,1 & $\begin{array}{r}6.240 \\
352 \\
2.034 \\
\end{array}$ & 10 & 4,3 \\
\hline $\begin{array}{l}\text { Näo } \\
\text { caracterizada }\end{array}$ & $\begin{array}{l}\text { MAXIMO } \\
\text { MINIMO } \\
\text { MEDTO } \\
\end{array}$ & $\begin{array}{r}8.319 \\
335 \\
1.428 \\
\end{array}$ & 23 & 17,0 & $\begin{array}{r}3.570 \\
220 \\
963 \\
\end{array}$ & 10 & 10,3 & $\begin{array}{r}8.319 \\
220 \\
1.287 \\
\end{array}$ & 33 & 14,2 \\
\hline $\begin{array}{l}\text { Sem } \\
\text { fraturas }\end{array}$ & $\begin{array}{l}\text { MAXIMO } \\
\text { MINIMO } \\
\text { MEDIO } \\
\end{array}$ & $\begin{array}{r}12.024 \\
496 \\
2.523 \\
\end{array}$ & 29 & 21,5 & $\begin{array}{r}14.667 \\
388 \\
2.376 \\
\end{array}$ & 21 & 21,6 & $\begin{array}{r}14.667 \\
388 \\
2.461 \\
\end{array}$ & 50 & 21,6 \\
\hline MEDIA GERAL & & 2.367 & & & 2.565 & & & 2.450 & & \\
\hline
\end{tabular}


Observa-se, por outro lado, que não hä grande diferença entre os värios tipos de fratura, variando a mëdia de R.S. desde $1.287 \mathrm{mg} / 1$ nos poços com fraturas não caracterizadas, atē 2.676 $\mathrm{mg}$ $/ 1$ nos poços com fraturas angulares de cisalhamento.

Essa pequena variação de um tipo de fratura para outro, vem a revelar a quase total ausência de relação do resíduo seco com o tipo de fraturas. Essa assertiva não é verdadeira, apesarade aparentemente correta, pelas evidências dos fatos. Com efeito, se a fratura $\vec{e}$ mais aberta (originada por tração) deverä ocorrer maior infiltração, melhor circulação e renovação mais eficaz , a carretando menor salinização por evaporação e concentração. A menor abertura (originada por cisalhamento) acarreta, ao conträrio, maior dificuldade na infiltração e circulação, promovendo uma mai or salinidade por evaporação e concentração progressiva.

Era de se esperar portanto, baixos teores de sais nos poços com fraturas tracionais (transversal ou longitudinal) e eleva. dos teores nos poços com fraturas de cisalhamento (angular ou lon gitudinal). A razão de não ocorrer esse relacionamento, devemse ao fato de que outros fatores mais importantes se sobressaem no contexto do tratamento estatîstico global.

7.2.11. RELAÇÃO RESTDUO SECO X PROFUNDIDADE DE ENTRADA D'AGUA

A representação em gxâfico mono-log (Fig. 7.7) da profundiade de entrada d'ägua contra o resîduo seco (na escala logarítmica) foi realizada com os poços da região oriental do Estadosda paraîba. A escolha dessa região, como amostragem, deveürse ao fato de serem ali os valores do R.S. mais variâveis, e de constar no cadastro apenas a entrada d'ägua principal, o que melhor carac teriza a contribuição desse elemento no binômio que se procura re lacionar.

o gräfico da Fig.7.7 mostra uma"nuvem de pontos" distribu ídos aleatoriamente, não revelando qualquer relação direta ou indireta entre os dois parâmetros considerados. A anảise de regres são revelou todavia uma fraca relação direta, com indice de corre laçāo de 0,3 entre as variảveis. Apesar da fraca relação apresenta da (ver Quadro 7.18), pode-se deduzir do gräfico, que: 
FIG. 7.7 .

RESIDUO SECO $x$

(m)

PROFUNDIDADE

DE ENTRAdA D'ÁGUA (REgİ̃o

ORIENTAL da PARAIBA)

40

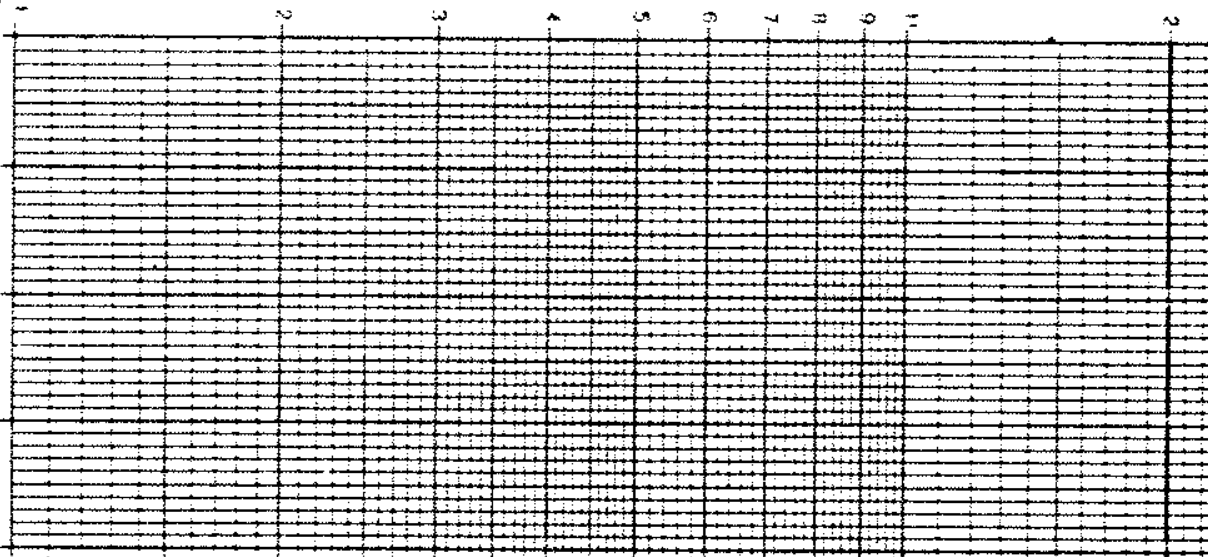

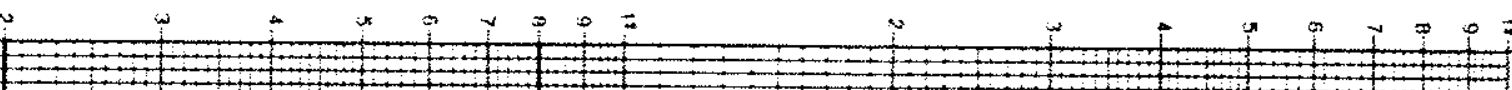

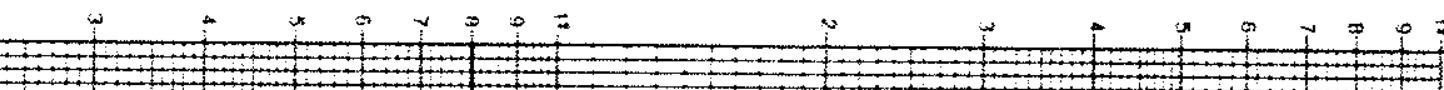

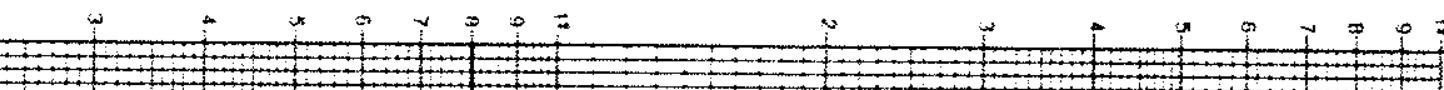

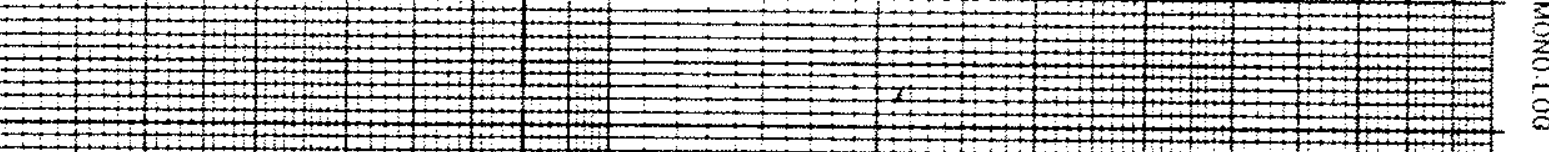

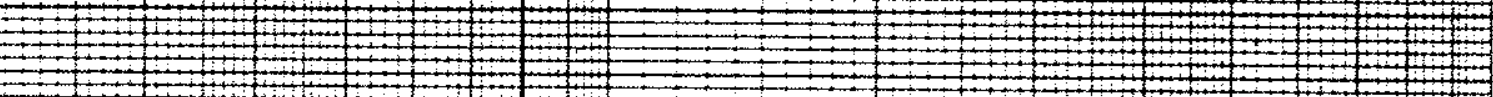

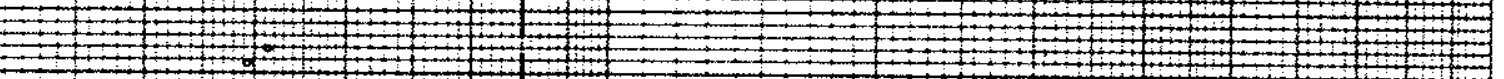

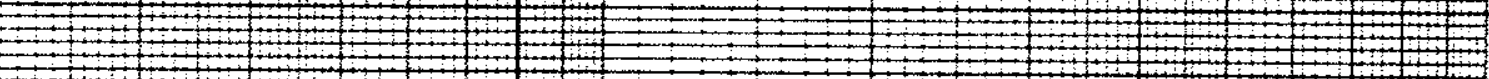

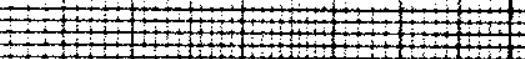

30

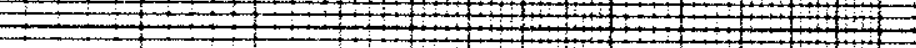

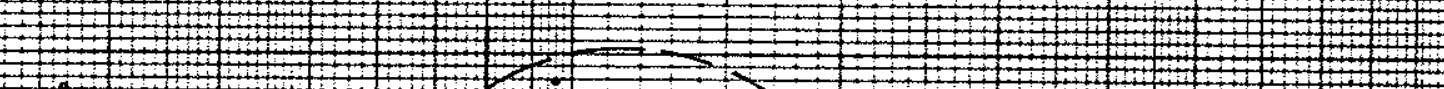

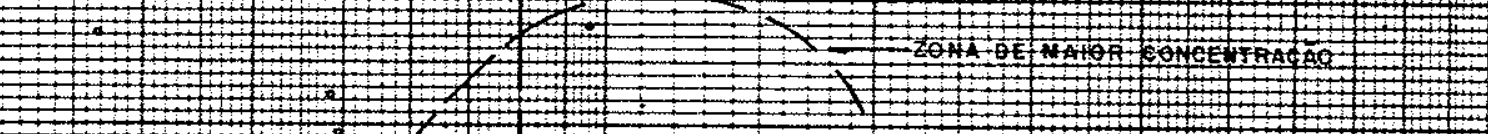

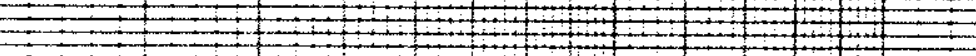

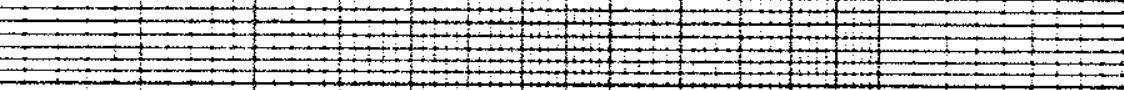

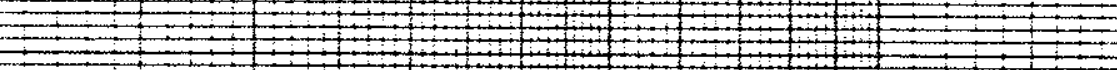

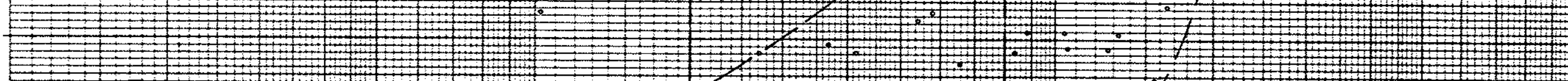

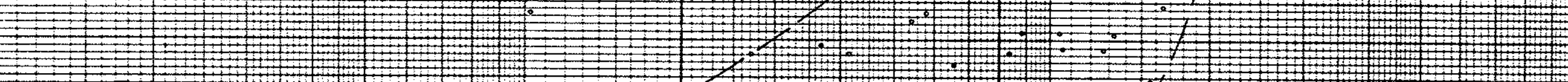

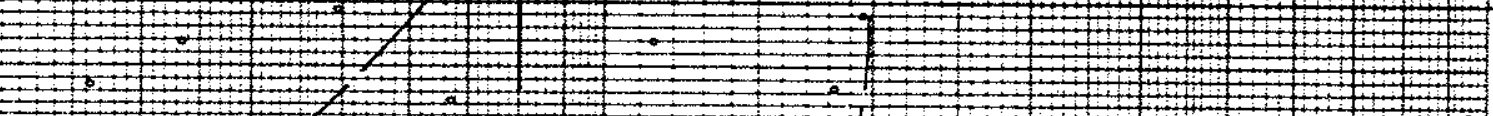

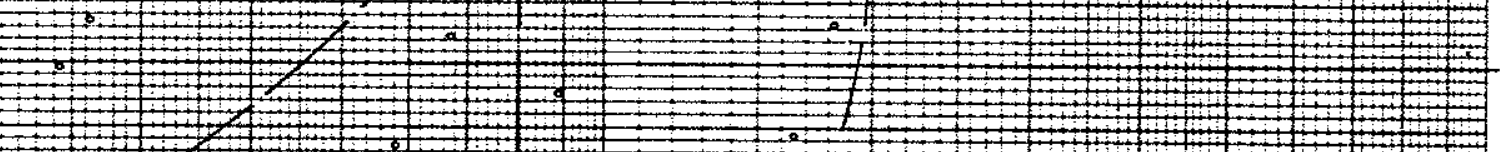

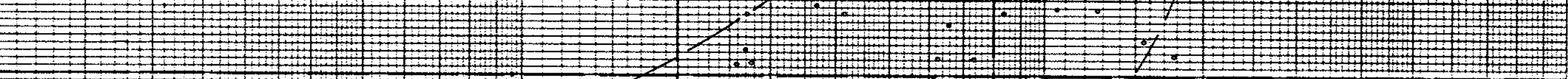

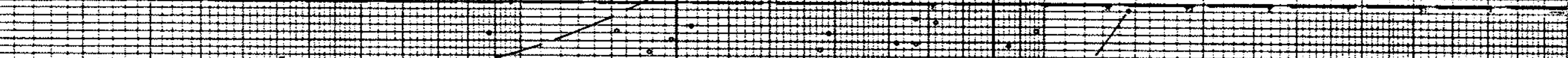

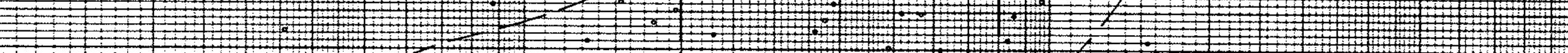

$20-$

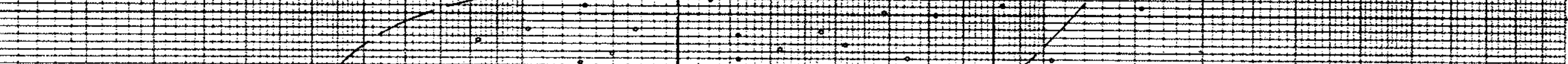

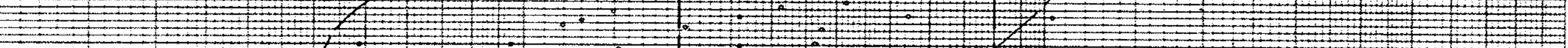

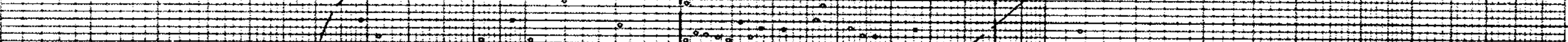

10 $1+1+1$

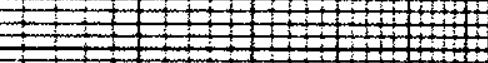

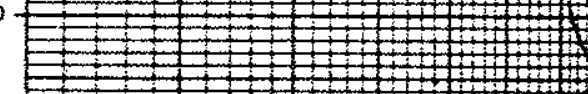

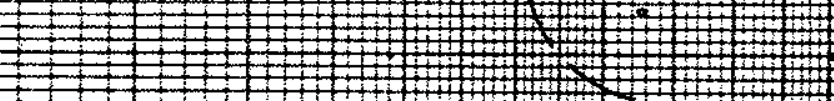
过

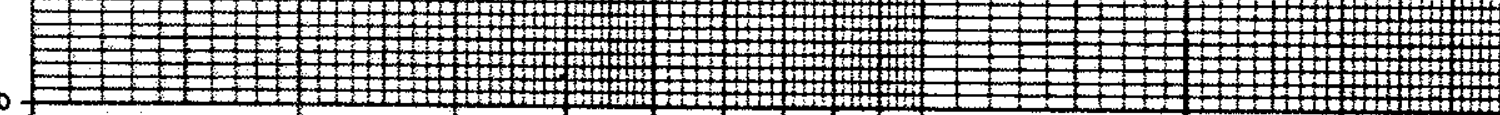

100
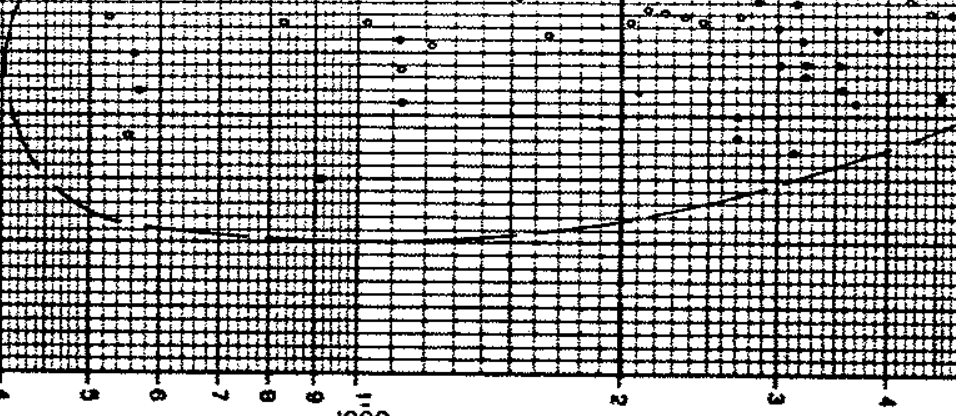

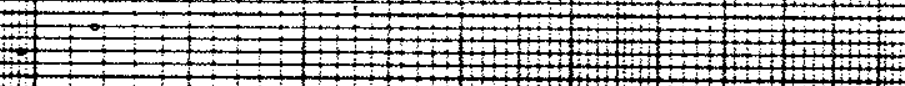

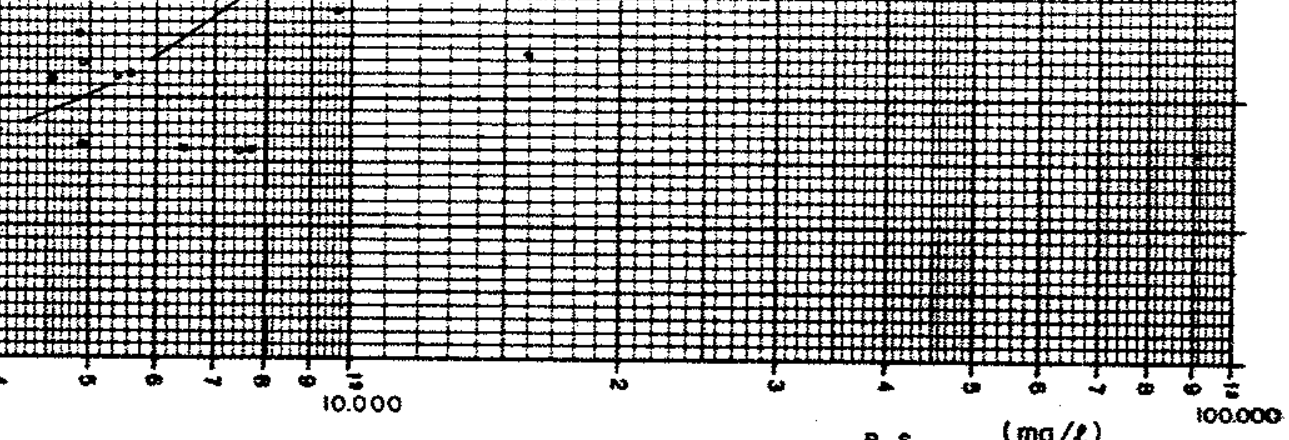

R.s. $(\mathrm{mg} / \mathrm{l})$ 
QUADRO 7.18 - CORRELAÇAO ENTRE O RESIDUO SECO E A PROFUNDIDADE DE ENTRADA D'AGUA NA REGIAO ORIENTAL DO ESTADO DA PARAIBA

\begin{tabular}{|c|c|c|c|c|}
\hline & $X, Y$ & $\log X, \log Y$ & $\log X, Y$ & $X, \log Y$ \\
\hline MEDIA DA VARIAVEL DEPENDENTE & $4.685,17$ & 3,523 & $4.685,17$ & 3,523 \\
\hline MEDIA DA YARIAYEL INDEPENDENTE & 20,65 & 1,271 & 1,27 & 20,650 \\
\hline DESUTO PADRAOO DA YAREAYEL DEPENDENTE & $3.987,04$ & 0,374 & $3.987,0.4$ & 0,374 \\
\hline DESVIO PADRAOO DA YARIÄYEL INDEPENDENTE & 9,62 & 0,125 & 0,12 & 9,622 \\
\hline VALOR DO COEFICIENTE $\bar{b}$ & $2.154,60$ & 2,850 & $-2.733,26$ & 3,287 \\
\hline VALOR DO COEFTCIENTE a & 122,53 & $0,52.9$ & $5.857,0.8$ & 0,011 \\
\hline COEFICIENTE DE CORRELAÇAO CRI & 0,295 & 0,276 & 0,286 & 0,294 \\
\hline
\end{tabular}


19) todos os poços com resîduo seco inferior a $1.000 \mathrm{mg} / \mathrm{l}$ apresentaram a entrada d'agua principa1, a menos de $25 \mathrm{~m}$ de profundidade.

$\left.2^{\circ}\right)$ dos poços com resĭduo seco atê $2.000 \mathrm{mg} / 1,93 \%$ ocorrem a profundidades da entrada d'ägua inferiores a $25 \mathrm{~m}$.

$\left.3^{\circ}\right)$ dos poços com profundidades de entrada d'ägua superio res a $25 \mathrm{~m}, 8,1 \%$ possuem R.S. inferior a $2.000 \mathrm{mg} / 1$, $54,0 \%$ apresentam R.S. entre 2.000 e $8.000 \mathrm{mg} / 1$ e $37,8 \%$ têm R.S. maior que $8.000 \mathrm{mg} / 1$.

$\left.4^{\circ}\right)$ dos poços que possuem R.S. maior que $8.000 \mathrm{mg} / 1,1 / 3$ possuem entradasd'ägua inferiores a $25 \mathrm{~m}$ de profundida de e $2 / 3$ com profundidades superiores a $25 \mathrm{~m}$.

Em suma, a profundidade da entrada d'água, na maioria dos casos, interfere na qualidade da ăgua de maneira direta, isto $\vec{e}$, à medida que aumenta a profundidade, aumenta o teor de sais dissolvidos na ägua.

No gräfico em questão, pode-se visualizar a zona de maior concentração, em forma de uma salsicha encurvada, com. ramo ascen dente para a região superior-direita da figura, revelando uma ten dência ao crescimento do R.S. com o aumento da profundidade de en trada d'ägua.

Essa relação não constitui nenhuma anomalia, ao conträrio, era jă esperada sua ocorrência, visto que à medida que aumenta a profundidade, vão diminuindo as fraturas em intensidade e tambëm em abertura.Com isso, a circulação da ăgua ē mais lenta, a renovação mais precäria e o gradativo aumento de salinidade tende naturalmente a ocorrer com o tempo.

Em trabalho realizado em Petrolina (PE), CRUZ (1974) correlacionou o resîduo seco com a profundidade de entrada d'água em 35 (trinta e cinco) poços, localizados numa mesma região ( o que afasta a influência do clima). Nessa pesquisa, o autor constatou que abaixo da profundidade de $45 \mathrm{~m}$ ( os poços variavam atê mais de $90 \mathrm{~m}$ de profundidade), $70 \%$ das äguas apresentaram R.S. acima de $3.000 \mathrm{mg} / 1$, com mêdia de $5.000 \mathrm{mg} / 1$, enquanto que, acima dessa pro fundidade (entradas d'ägua mais rasas), $72 \%$ tiveram R.S. menor que $3.000 \mathrm{mg} / 1 \mathrm{com}$ mêdia de $2.500 \mathrm{mg} / 1$, o que significa dizer que para a profundidade supexior a $45 \mathrm{~m}$, a salinidade praticamente do- , brou. A pesquisa revelou ainda, que nas âguas mais superiores (de 
menor profundidade) o tipo dominante era o bicarbonatado, enquanto os cloretos aumentaram com a profundidade.

\subsubsection{RELAÇAO ENTRE RESIDUO SECO X PROFUNDIDADE DO POÇO}

A amostragem procedida, correspondeu aos poços localizados na região oriental do Rio Grande do Norte, em nümero de 127 por possuirem uma larga variação de valores de salinidade.

o elevado nümero de profundidades iguais - 57 poços com profundiade de $60 \mathrm{~m}$, acarretou uma concentração linear de valores variâveis em salinidade, o que impediu uma corvelação matemática entre esses dois parâmetros. Os coeficientes de correlação ten'ta dos em escala X, Y; $\log X, \log X ; \operatorname{logX}, Y ; X, \log Y$, foram todos muito bajxos como mostra o Ouadro 7.19.

Entretanto, analisando-se o grâfico mono-log (Fig.7.8) constata-se uma certa "tendência" para concentração da "nuvem de pontos", segundo uma elipse, com eixo maior inclinado para a área superior-direita do gráfico, o que implicaria numa relação direta entre os dois parâmetros analisados.

Alêm dessa disposição elíptica dos pontos, deve ser chamada a atenção para os seguintes fatos:

1.) todos os 30 poços com R.S. $>8.000 \mathrm{mg} / 1$ possuem profundidades superiores a $40 \mathrm{~m}$, sendo $23,3 \% \mathrm{com}$ profundidades entre 40 e $50 \mathrm{~m}$ e $76,7 \%$ com profundidades superiores a $50 \mathrm{~m}$.

29) dos poços com profundidades superiores a $60 \mathrm{~m}, 50 \%$ pos suem R.S. entre 3.500 e $6.000 \mathrm{mg} / 1$ e os outros $50 \%$ possuem R.S. $>10.000 \mathrm{mg} / 1$.

3\%) dos poços com R.S. < $2.000 \mathrm{mg} / 1$, $55 \%$ possuem profundidades inferiores a $50 \mathrm{~m}$ e $45 \%$ apresentam profundidades entre 50 e $60 \mathrm{~m}$.

Essas observações permitem detectar uma fraca relação direta entre o resîduo seco e a profundiade do poço, no sentido de que, as âguas dos poços mais profundos tendem a ser mais salinizadas. Essa relação, aliâs, não poderia deixar de existir, uma 
FIG. 7.8 - RELAÇĀO ENTRE RESIDUO SECO E PROFUNDIDADE DO POÇO (REGIĀO ORIENTAL DO RIO G. DO NORTE)

(m)

(m)-

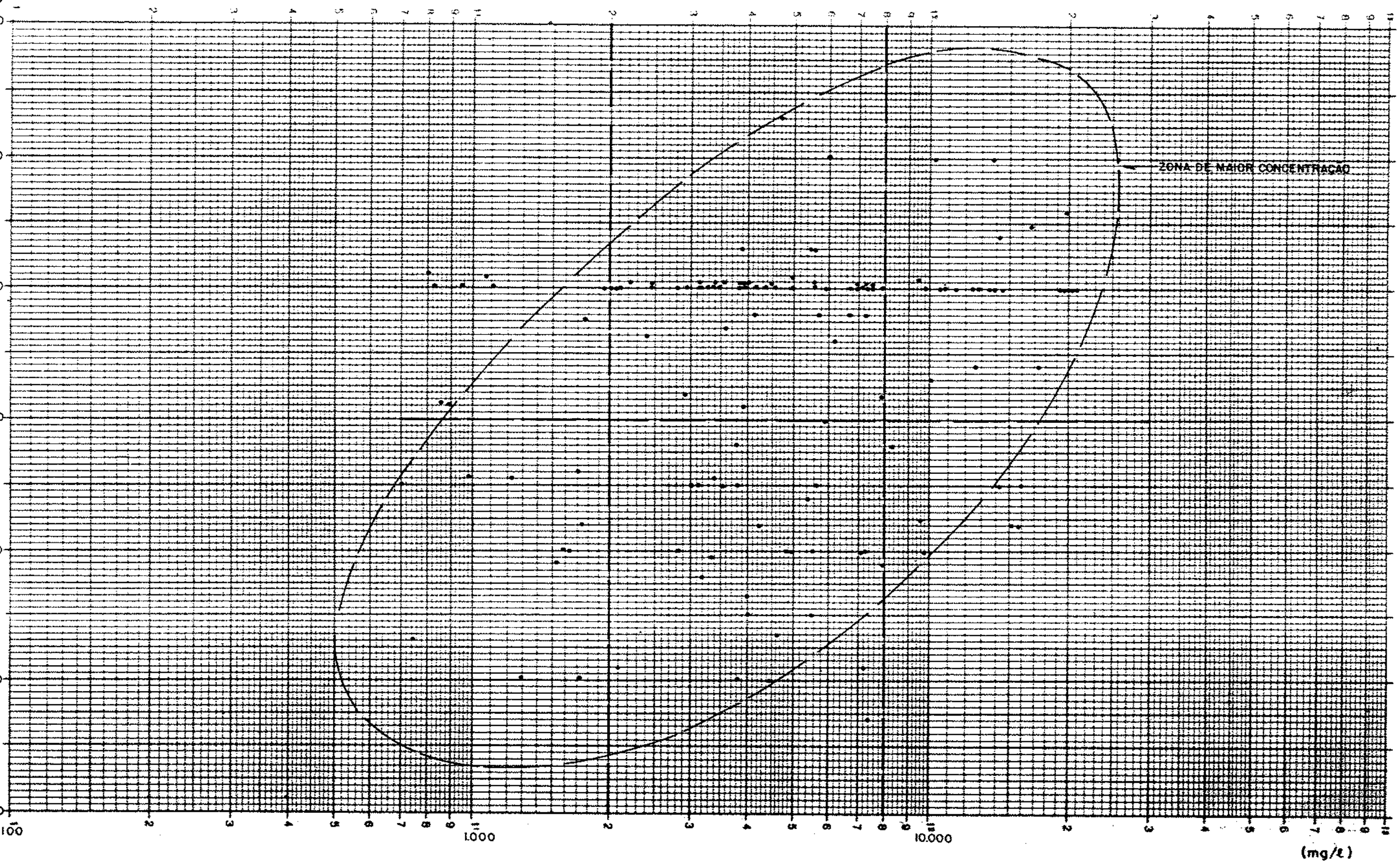


QUADRO 7.19 - CORRELAÇAO ENTRE O RESIDUO SECO E A PROFUNDIDADE DO POÇO, NA REGIÃO ORIENTAL DO ESTADO DO RIO GRANDE DO NORTE

\begin{tabular}{|c|c|c|c|c|}
\hline & $\mathrm{X}, \mathrm{Y}$ & $\log X, \log Y$ & $\log X, Y$ & $X, \log Y$ \\
\hline MEDIA DA YARTEVEL, DEPENDENTE & $6.204,21$ & 3,640 & $6.204,21$ & 3,640 \\
\hline MEDIA DA VARTEYEL INDEPENDENTE & 54,36 & 1,720 & 1,72 & 54,360 \\
\hline DESVIO PADRAO DA YARFAYEL DEPENDENTE & $5.354,03$ & $0,385$. & $5.354,03$ & 0,385 \\
\hline DESUTO PADRAOO DA YARIAYEL INDEPENDENTE & 10,87 & 0,093 & $0,0.23$ & 10,870 \\
\hline YALOR DO COEFICIENTE $\bar{b}$ & $6.008,55$ & $3,53 \alpha$ & $3.340,30$ & 3,660 \\
\hline VALOR DO COEFTCIENTE a & 3,60 & $0,0,03$ & $1.659,50$ & $-0,0,003$ \\
\hline COEFICIENTE DE CORRELAÇAO (R) & 0,0073 & 0,015 & 0,022 & $-0,010$ \\
\hline
\end{tabular}


vez que jấ foi detectada a relação do resîduo seco com as entradas d'âgua, e estes, por sua vez, estão intimamente relacionados com a profundidade do poço.

Em geral, quando o poço e mais profundo, ê porque ?não forneceu água suficiente, a menores profundidades, tendo que ser aprofundado e alcançadas entradas d'ägua (fraturas) mais profundas.

7.2.13. RELAÇAO RESTDUO SECO X MANTO DE COBERTURA

Como amostragem para investigação dessa relação, foram utilizados os dados da região oriental do Estado da Paraỉba, pela maior diversificação de valores de salinidade.

Foram plotados em papel mono-log os valores de resïduo se co (na escala log) contra a espessura do manto de cobertura (esCala decimal). O gräfico da Fig. 7.9. revela que não existe qualquer relação entre os parâmetros em referência.

A amostragem, se bem que bem diversificada, quanto ao resíduo seco, foi muito pouco variävel quanto a espessura do manto, apresentando $36,8 \%$ dos valores com espessura de $3 \mathrm{~m}, 27,1 \%$ com es pessura de $1,0 \mathrm{~m}, 13,5 \%$ sem qualquer manto (espessura zero), 10,5\% acima de $3 \mathrm{~m}$ e o restante em pontos esparsos.

Uma observação que se poderia fazer no gräfico em questão, ê que $70 \%$ dos poços com R.S. $>10.000 \mathrm{mg} / 1$, possuem manto de cobertura igual ou inferior a $1,0 \mathrm{~m}$ de espessura.

Entretanto, não se pode generalizar, pois, alëm de existirem vârios poços com baixa salinidade e delgado capeamento, ocor rem, ao conträrio, espessos capeamentos com elevada salinidade.

0 resultado da análise de regressão mostrado no Quadro 7.20 mostra igualmente a inexistência de correlação entre essas varia ây veis . 
$>10 \rightarrow$

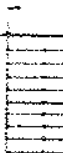

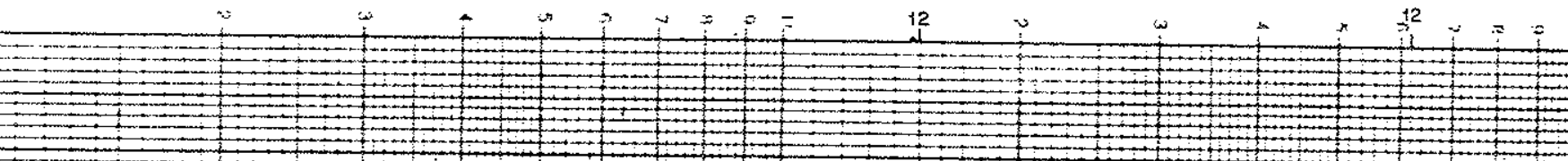

10

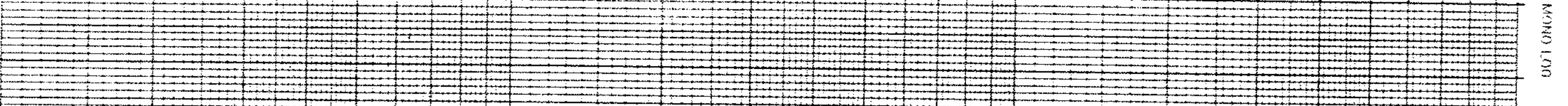

$9+$

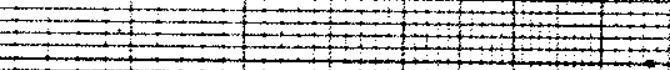

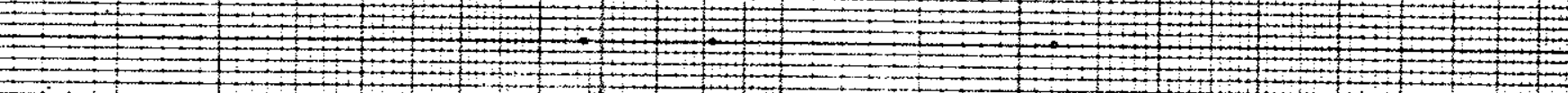

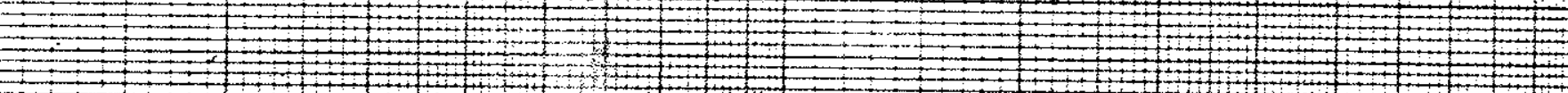

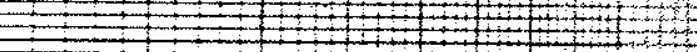

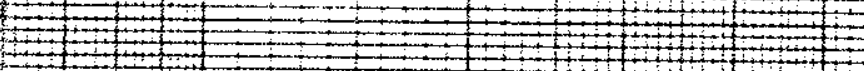

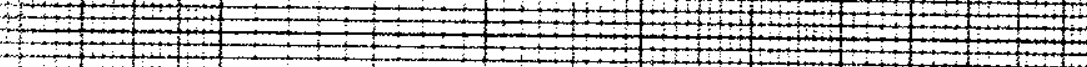

$7+$

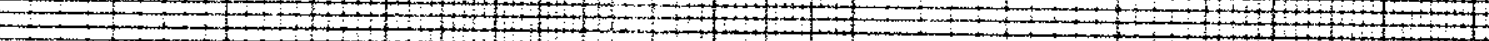

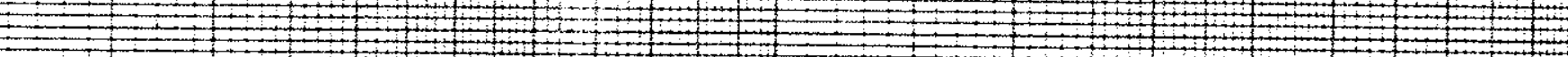

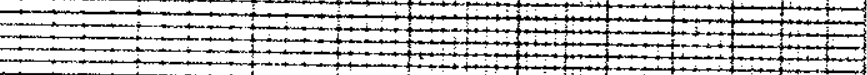

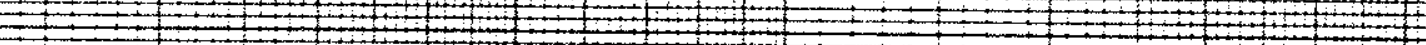

$\cdot$

5

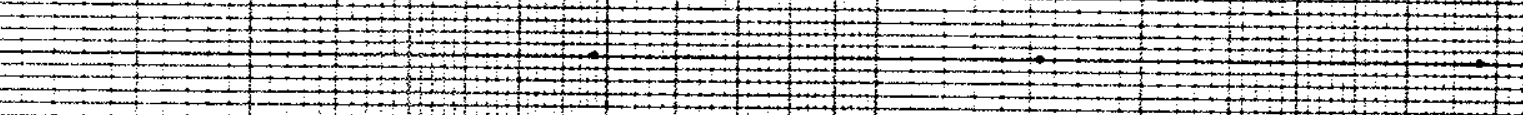

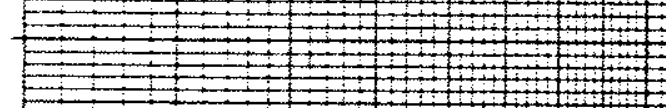

4 $+1+2+1+2$

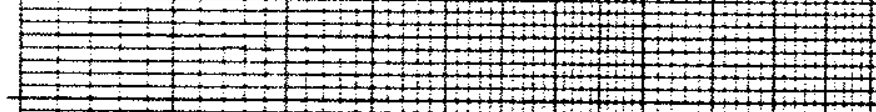

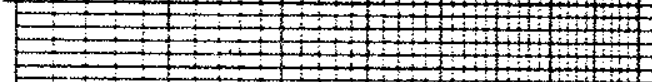

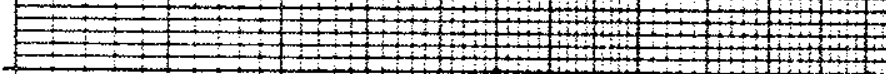

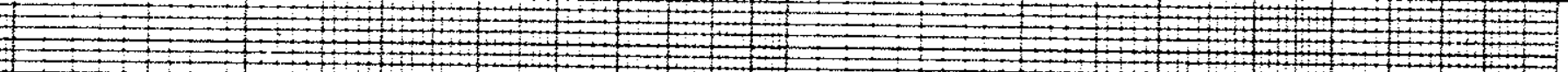

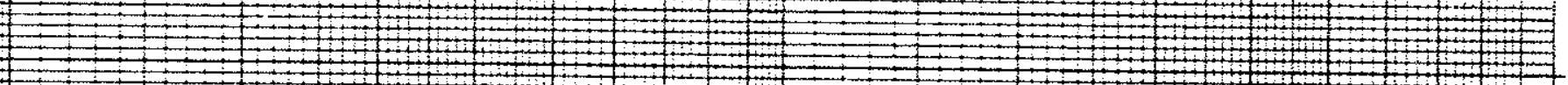

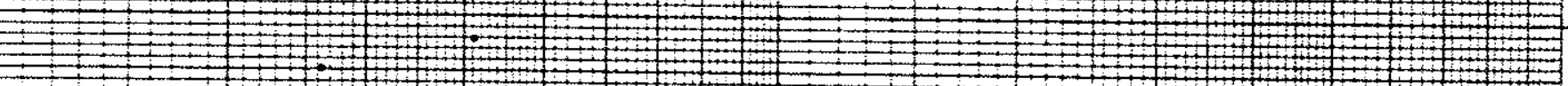

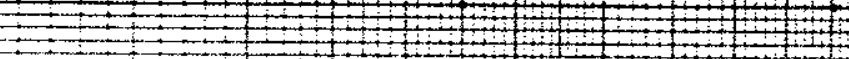

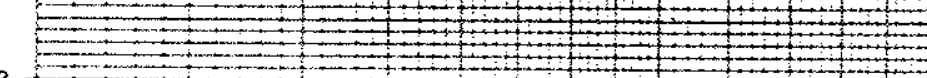

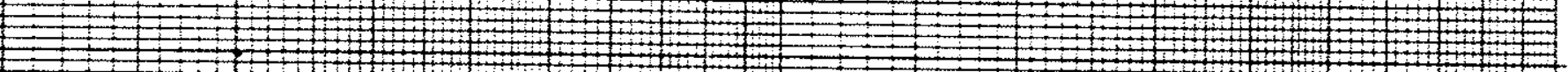

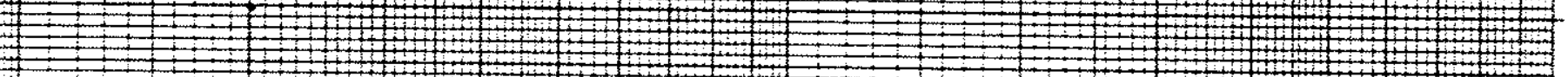

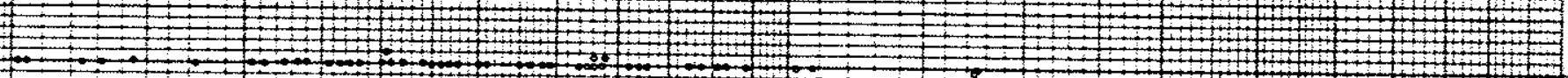

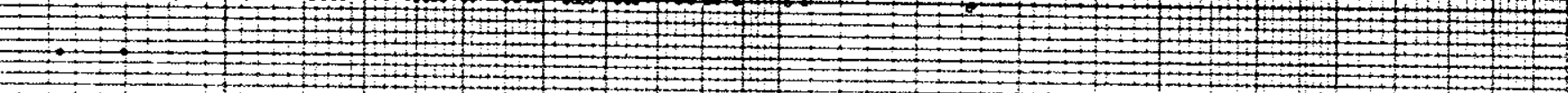

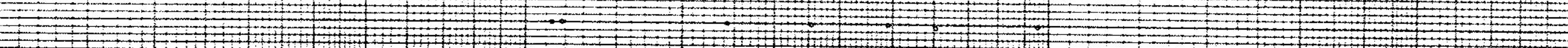

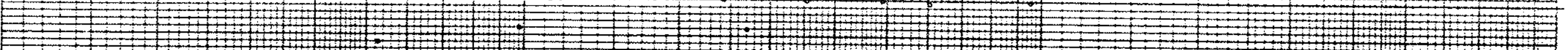

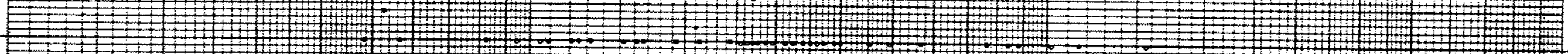

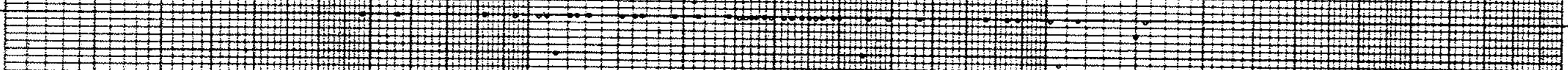

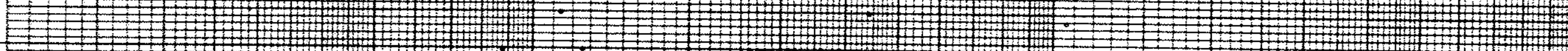

0 $+1+1+1+1+1+1+1+20$

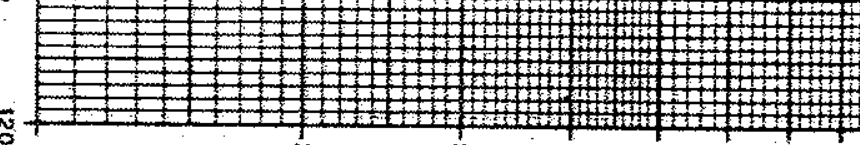


QUADRO 7.20 - CORRELAÇAO ENTRE O RESIDUO SECO E O MANTO DE COBERTURA NA REGIAO ORIENTAL DO ESTADO DA PARAIBA

\begin{tabular}{|c|c|c|c|c|}
\hline & $X, Y$ & $\log X, \log Y$ & $\log X, Y$ & $X, \log Y$ \\
\hline MEDFA DA YARFAUEL DEPENDENTE & $4.281,28$ & $3,49.7$ & $4.281,28$ & 3,427 \\
\hline MEDIA DA YARIAYEL INDEPENDENTE & 2,70 & 0,328 & $\alpha, 328$ & 2,700 \\
\hline DESYIO PADRAO DA YARIEYEL DEPENDENTE. & $3,449,34$ & $a, 359$ & $3.449,34$ & a, 359 \\
\hline DESVIO PADRAO DA YARIEYELL INDEPENDENTE & 2,10 & $a, 301$ & $a, 30$ & 2,100 \\
\hline YALOR DO COEFICIENTE $\bar{\hbar}$ & $4.433,22$ & $3,50.3$ & $4.320,00$ & $3,5.23$ \\
\hline YALOR DO COEFICIENTE a & $-56,48$ & $-0,0.2$ & $=332,5.2$ & $-0,0028$ \\
\hline COEFICIENTE DE CORRELAÇAO (RI & $=0,0.34$ & $-0,018$ & $=0,029$ & $-0,057$ \\
\hline
\end{tabular}




\subsubsection{RELAÇAO RESIDUO SECO X RELEVO/HIDROGRAFIA}

Quanto a relação entre a qualidade da ägua e o relevo/hidrografia, foi feita uma tentativa, sem contudo apresentar um resultado coerente. Em princípio, a situação de depressão fluvial ( talvegue) deveria propiciar melhores condições de recarga e, .. om consequência, mais baixos teores de salinização. Pela mesma razão, na medida que diminuisse a recarga, nas encostas e interflüvios, a salinização deveria aumentar progressivamente. Na prätica, não se verifica esse relacionamento, em virtude da participação de ou tros fatores que atuam no processo de salinização, sobretudo,como $j \vec{a}$ foi dito antes, o clima regional. Assim, $\vec{e}$ que nas bacias hi drogräficas, de elevada salinidade, como aqueles que drenam de oeste para leste, acontece muitas vezes o conträrio da situação esperada, isto $\vec{e}$, no vale principal do rio, onde o trajeto percor rido ê maior, as âguas infiltradas são mais salinizadas, enquanto que alguns vales tributârios, de menor percurso, apresentam água de melhor qualidade. Essa inversão da situação ê frequentemente constatada nas bacias dos rios Cearâ-Mirim, Potengi, Curimatau e paraíba.

7.2.15. RELAÇAO RESIDUO SECO X CLIMA

Conforme apresentado no Cap.6, o resïduo seco das äguas dos poços da região ocidental ê bem inferior ao das äguas dos poços da região oriental, em ambos os Estados. Em termos médios, o resîduo seco da região ocidental, representa apenas $27 \%$ daquele da região oriental (ver Quadro 6.1 , Cap.6)

Foi analisado, tambẻm, nos capîtulos de climatologia, relevo e hidrografia, a diferenciação existente entre as regiões oriental e ocidental, separadas por uma dorsal morfolögica de dire ção, aproximadamente, norte-sul.

Essa dorsa1, como pode ser visto comparando-se as figuras 4.2 com 4.12 , coincide com a faixa de maior aridez do nordeste?, com indices variâveìs entre 10 e 15 e isoietas em torno de $400 \mathrm{~mm}$ /ano. Nessa zona, a evaporação ê sempre superior a precipitação, 
estando os solos, na maior parte do ano, com deficiência de ägua. Os sais são trazidos de zonas mais profundas e precipitadas no so 10 pela evaporação da ăgua, sendo em parte, transportadas pelos cursos d'âgua é, em parte, re-infiltradas. Esse processo contínuo, acarreta gradativos aumentos de salinização da região e, os rios que têm ali as suas nascentes, tendem igualmente a ser salinizados. E justamente isso o que acontece com a drenagem da regiäo oriental, cujas nascentes são na maior parte(excetuando-se o ramo sul-ocidental da bacia do Paraíba) originadas nessadorsal de extrema aridez.

Enquanto isso, os cursos d'água das bacias ocidentais são originados ou na Serra do T'eixeira, onde a pluviometria chega a $1.000 \mathrm{~mm} /$ ario, onde nascem os värios cursos que formam a bacia do rio piranhas, principalemnte os rios Piancö e Espinhares ;ou nas grandes elevaçöes orientais, limîtrofes dos Estados do R.G.do Nor te, Paraíba e Cearä, como as serras de S.Jose ${ }^{\star}$, Cantinho, Camarä, João do Vale, Martins, etc., cabeceiras da bacia hidrogräfica do rio Apodi, com pluviometria de 800 a $1.000 \mathrm{~mm} / \mathrm{ano}$.

Do exposto, pode-se concluir que a principal causa de sa1inização das águas de poços da região oriental è o clima, ou, mais precisamente, a deficiência em precipitação que acarreta salinização dos cursos hîdricos superficiais, que vão recarregar os aquîferos fissurais. E entäo uma relação inversa, pois, na medida que diminui a precipitaçäo, aumenta a salinidade.

\subsection{STNTESE DAS RELACOES ANALISADAS}

A vazão específica e o resíduo seco são os dois parâme tros do poço que caracterizam respectivamente a quantidade $e$ a qualidade da ägua armazenada no aquífero em estudo.

Esses dois parâmetros foram correlacionados com alguns fa tores endögenos (tipo de rocha, tipo de fratura, entrada d'ägua e profundidade do poço) e outros fatores exögenos (manto de cober. tura, relevo/hidrografia e clima), na tentativa de estabelecer funções diretas ou inversas de relação daqueles parâmetros com esses fatores. 
Uma sẻrie de condiçôes limitantes interferiram no sentido de impedir um resultado mais preciso nessa correlação, dentre eles os seguintes:

$\left.1^{\circ}\right)$ a existêncìa de valores anômalos, tanto de vazão especîfica, como de resîduo secio, que perturbaram : a mâdia dos dados, induzindo a valores pouco representativos.

$\left.2^{\circ}\right)$ a grande dispersão de valores em torno da média , a carretando desvios padrões, comumente acima do valor da mêdia, ou seja, coeficientes de variação superiores a $100 \%$.

$\left.3^{\circ}\right)$ a simultânea atuação dos diversos fatores nos parâme tros considerados.

Em nenhuma correlação gräfica tentada, logrou-se conse guir uma equação matemâtica que definisse uma reta, uma curva ou qualquer representação estatîstica, mesmo processando-se os dados atravês de programa computadorizado dos mínimos quadrados.

Apesar disso, se conseguiu, atravês de uma anälise inter pretativa dos grâficos e tabelas (quadros), estabelecer correla ções entre os dois parâmetros e os fatores considerados.

O Quadro 7.21 resume os resultados dessas correlações, não sendo nele incluîda a relação entre os dois parâmetros do poço - vazão específica $x$ resíduo seco.

Essa relação entre os parâmetros ê inversa, apesar de incipiente, conforme anảlise efetuada em 7.2.1. Essa inversão na re1ação entre os dois parâmetros traz, como consequência, uma total inversão na relação entre cada fator analisado para com os parâmetros, ou seja, se um determinado fator guarda uma relação direta com a vazão especîfica, fatalmente terä relação inversa com o resíduo seco.

Esse fato pode ser constatado em todos os casos, em que a relação não ê especî́fica com determinados tipos do elemento ana1isado. Desse modo, a entrada d'âgua, a profundidade do poço e o manto de cobertura, apresentam relações inversas com a vazão especî́fica e direta com o resîduo seco, excetuando-se apenas o manto de cobertura, que não guarda nenhuma relação com o R.S. Quanto ao clima, ocorre o contrârìo, a relação ê direta com a vazão especî́fi- 
ca inversa com o R.S.

No que se refere às relações entre os parâmetros vazão especifica e residuo seco com o tipo de rocha, tipo de fratura e relevo/hidrografïa, não podem ser expressas simplesmente como direta ou inversa, pois apresentam uma variação em função das classificações adotadas para as rochas, fraturas e situaçōes de relevo associado à hidrografia. Assím, a relação è de que tipo de rocha, de fratura e de relevo ê mais favorävel ou mais desfavorävel. à obtenção de uma melhor vazão especifíca e de uma' salinidäde mais baixa. 
QUADRO 7.21 - RESUMO DAS CORRELAÇOES ENTRE FATORES E PARAMETROS DOS POCOS

\begin{tabular}{|c|c|c|}
\hline FATORES & $\begin{array}{c}\text { VAZAOO } \\
\text { ESPECIFICA } \\
(1 / \mathrm{h}) / \mathrm{m}\end{array}$ & $\begin{array}{c}\text { RES IDUO } \\
\text { SECO } \\
(\mathrm{mg} / 1)\end{array}$ \\
\hline TIPO DE ROCHA & ESPEC IFICA & $\begin{array}{l}\text { ESPECIFICA } \\
\text { (Fraca) }\end{array}$ \\
\hline TIPO DE FRATURA & ESPECIFICA & $\begin{array}{l}\text { ESPECTFICA } \\
\text { (Fraca) }\end{array}$ \\
\hline PROFUNDTDADE DO POÇO & INVERSA & $\begin{array}{l}\text { DIRETA } \\
\text { (Incipiente) }\end{array}$ \\
\hline $\begin{array}{l}\text { PROFUNDIDADE DE ENTRA } \\
\text { DA D'AGUA }\end{array}$ & $\begin{array}{l}\text { INVERSA } \\
\text { (Incipiente) }\end{array}$ & DIRETA \\
\hline MANTO DE COBERTURA & $\begin{array}{l}\text { INVERSA } \\
\text { (Incipiente) }\end{array}$ & INEXISTENTE \\
\hline RELEVO/HIDROGRAF IA & ESPECIFICA & ESPECTFICA \\
\hline CLIMA (PRECIPTTAÇAO) & DIRETA & INVERSA \\
\hline
\end{tabular}


CAP ITULO No 8

A LOCACAO DO POCO A LUZ DOS NOVOS CONHE CIMENTOS - ZONEAMENTO HIDROQUIMICO PARA A ARHA PILOTO 
o estudo levado a efeito não teve o enfoque exclusivo da locação do poço, porëm a anälise dos fatores que conduzem ao melhor ou pior resultado do poço, induz fatalmente a pesquisa à essa aplicação, ou seja, em outras palavras, o objetivo da pes quisa foi analisar a relação dos fatores com a produção e quali dade da água no poço enquanto a finalidade desse conhecimento foi obter locações de poços mais precisas.

Se a finalidade precípua da pesquisa é a obtenção de me 1hores locações, a metodologia de trabalho para a locação do po ço, deve ser enfocada, aparecendo o resultado do atual estudo como uma ferramenta a ser utilizada no processo sistemätico da: locação.

A locação de um poço no aqüífero fissural deve ser pro cessada em duas etapas: a primeira no escritörio, a partir do material cartogräfico e bibliogräfico e a segunda, no campo.

$\mathrm{Na}$ etapa inicial, deve o hidrogeólogo munir-se do se guinte material de consulta, acêrca da área onde vai trabalhar:

- mapas plani-altimétricos na maior escala possivel

- mapas geológicos na escala de detalhe, se possivel

- fotografias aéreas e, se disponivel, imagens de satê 1.ite

- fichas de poços existentes na região

- relatórios tệnicos sobre estudos realizados na ärea

o mapa plani-altimëtrico não se destina à locação empîri ca por métodos radiestésicos, usando-se varinhas, bastões ou pên dulos, e sim para uma anälise das caracteristicas do relevo e da hidrografia da ärea. Muitas informações podem ser auferidas de $\underline{u}$ ma carta plani-altimétrica bem feita, atê mesmo relações geomor fológicas como associações de lineamentos estruturais, estruturas rupturais, estruturas dobradas, etc. Mas as principais observa ções a serem feitas nessa carta são a do posicionamento das for mas elevadas do relevo, as depressões e os vales hidrogräficos, no sentido de se efetuar uma prévia escolha das äreas rebaixadas, evitando-se, sobretudo, os divisores d'água e altiplanos; alén dis 
so, a disposição "da rede hidrogräfica è de fundamental importân cia. O tipo de drenagem, pode oferecer informações muito impor tantes quanto a litologia (rochas xistosas p.e. oferecem sempre uma drenagem dendritica) e quanto a estrutura (drenagem paralela ou rombica podem revelar sistemas de fraturamento diversificados. Deve ser lembrado que a associação drenagem-estrutura, que moti vou a criação do termo "riacho-fenda" constitui um dos critérios mais importantes para a locação do poço e ja a partir da carta plani-altimëtrica essa associação começa a ser detectada.

Da análise criteriosa do mapa plani-altimétrico deve re sultar a escolha de äreas alternativas para serem melhor caracte rizadas a partir dos outros materiais disponíveis.

O mapa geolögico, de preferência lito-estrutural (a1guns mapas distinguem apenas as grandes unidades estratigráficas, que compreendem värios tipos líticos) deve revelar os tipos de rocha existentes na ärea e as suas estruturas dobradas e quebradas.

Embora o papel desempenhado pelo tipo de rocha não seja tão importante como a sua estrutura, foi visto que algumas ro chas, por suas propriedades físicas (e dos seus minerais) apresen tam maior "vocação aqüífera" que outras. Assim, os paragnaisses, quartzitos e pegmatitos, são bem mais quebradiços que os granitos. de gran fina e os ortognaisses; por outro lado, os micaxistos a presentam uma intensidade de fraturamento bem maior que os gnais ses e as ardósias apresentam fraturas mais fechadas. Dessa manei ra, se houver possibilidade de opcões de escolha entre tipos $1 \underline{i}$ ticos que apresentem diferentes caracteristicas físicas, e conse quentemente, hidrogeológicas, essas observações devem ser consi deradas na escolha das "áreas alternativas".

Se o mapa geolögico é em nivel de detalhe (escala igual ou superior a 1:50.000) deverä conter, também, importantes informa ções acêrca da estrutura. As estruturas rupturais, bem como as as sociaçöes de dobramentos com rupturas (falhas, fraturas,etc), de vem ser meticulosamente analisadas, pois a partir dai, as "äreas alternativas" vão se tornando mais restritas e tendendo a linea ridade. Mesmo a nivel de mapa regional, ja se pode caracterizar, apos uma análise estrutural, os tipos diferentes de fratura, dis tinguindo-se as tracionais daquelas de cisalhamento (os casos de düvida serão elucidados na etapa de campo). 
Nas aero-fotos com recobrimento, que permitem uma visão tridimensiona1, pode-se analisar com mais detalhes as feiçoes lí tico-estruturais, bem como ainda, a existência ou não de manto de cobertura. O detalhamento nas informaçoes será função da esca la da fotografia. As escalas mais comuns, sobretudo na regiāo dó Nordeste do Brasi1, são de $1: 70.000$ e $1: 30.000$ ou 1:25.000;estas ültimas são as ideais para interpretacões 1ito-estruturais, per mitindo identificar o tipo de fratura fgenëtica e geometricamen te) e muitas vezes, o sentido de mergulho. Na maioria das vezes todavia, o sentido de mergulho com respectivo ângulo, somente po dem ser medidos no campo.

$A$ partir do estudo das aero-fotos, jä $\vec{e}$ possivel efetuarse nas "äreas alternativas" uma sërie de locações opcionais para escolha definitiva no campo. As situações mais favoräveis são a quelas de intersecção de fraturas alimentadas por drenagem super ficial e proximidades de contato geológico em condições de atin gir a rocha mais quebradica na parte superior do plano de fratura.

As imagens de satêlite não são muito indicativas da pre sença de ägua subterrânea em rochas fraturadas, servindo mais co mo apoio para se detectar as zonas de recarga representadas por aluviões ou coberturas rasas, saturadas de ägua.

As fichas de poços, existentes nas proximidades da áxea pesquisada, servem para fornecer indícios, sobretudo da qualidade química da ägua, que näo varia tanto de um pouco para outro, como a sua produtividade.

Os relatörios hidrogeológicos, a nivel regiona1, podem tam bëm fornecer indícios importantes, na medida em que possuam da dos confiảveis de quantidade e qualidade de ägua da ärea de inte resse.

Uma vez efetuadas as "locações opcionais", o hidrogeólogo vai ao campo para esclarecer as düvidas e obter informações mais seguras para a escolha do melhor local para o poço, ou poços no caso de programações mais amplas.

A etapa de campo é definitiva para a precisa locação do poço. A partir das "locaçōes opcionais" efetuadas no escritório, o hidrogeólogo deverá efetuar a escolha da melhor opcão, com base nas observações detalhadas de campo. 
os principais elementos a distinguir no campo, são o sen tido e o ângulo de mergulho dos planos de fratura e a partir des ses dados, a definição da distância do poço para a fonte de recar ga (rio, riacho, açude, lago,etc). As situações de interseção de duas fraturas ou mesmo de uma fratura aberta com superfícies de descontinuidade (xistosidade, clivagem, estratificação, contato geológico, etc) são as mais favoräveis para uma boa locação.

De um modo geral, poder-se-ia, a título de exemplo, ci tar as três situações (melhor, pior e regular) encontradas no campo, levando-se em consideracão os fatores atuantes na proble mätica de quantidade e qualidade da ägua armazenada:

a) a melhor situação:

- rocha: gnaisse, quartzito ou pegmatito

- Eratura: transversal tracional ou longitudinal trans versal

- entrada d'ägua: em maior nümero possível e à reduzidas profundidades (no mäximo até $40,0 \mathrm{~m}$ )

- profundidade do poço: em torno dos 40,0m

- manto de cobertura: aluvial arenoso, ou eluvial areno so (espessura de 20 a $30 \mathrm{~m}$ )

- relevo/hidrografia: talvegue ou proximidades (afastamen to mäximo de $5 \mathrm{~m}$ da calha fluvial)

- clima: chuvoso (com precipitacōes pluviométricas supe riores a $1.000 \mathrm{~mm} /$ ano).

b) uma situação intermediäria:

- rocha: micaxisto ou granito fraturado

- Fratura: longitudinal tracional

- entrada d'ägua: 2 a 3 entradas razoảveis profundida des de atê $40,0 \mathrm{~m}$

- profundidade do poço: em torno de 50,0m

- manto de cobertura: ausente ou eluvial arenoso

- relevo/hidrografia: encostas de vale,próximo ao fundo

- clima: regularmente chuvoso (precipitações entre 500 e $1.000 \mathrm{~mm} /$ ano)

c) a pior situação

rocha: filito, ardósia ou granito pouco fraturado 
- fratura: de cisalhamento ou sem fraturas

- entrada d'ägua: poucas e de pequena vazão

- profundidade do poço: igual ou superior a $60,0 \mathrm{~m}$

- manto de cobertura: espesso e argiloso

- relevo/hidrografia: no topo das elevaçoes ou interflü vios

- clima: ärido a semi-ärido (precipitações inferiores a $500 \mathrm{~mm} / \mathrm{ano}$ ).

Alëm dessa metodologia convencional de locação de poço, outras já têm sido usadas, algumas de maneira usual, outras em caräter experimental.

O mëtodo eletro-magnëtico denominado VLF (very low frequen cy) ja bastante difundido na prospeção mineral, sobretudo de mi nerais metálicos, foi sugerido pelo Dr. Ingemar Larson, durante a realização do Simposio de Hidrogeologia de Rochas Fraturadas, rea lizado em Recife, em 1979 .

O autor do presente trabalho efetuou uma pesquisa experi mental com o VLF, pela primeira vez no Brasil, tendo apresentado - resultado no 19 Congresso Brasileiro de Äguas Subterrâneas (Re cife, 1980). Dessa pesquisa, foram ressaltadas as grandes desvanta gens da aplicação desse método, dentre as quais se destacam:

1ạ) a grande morosidade para locação de um poço

2a) a ausência de detecção de fraturas segundo determina da direção (da emissão da onda eletromagnêtica, desde a fonte atē o receptor)

3ạ) a impossibilidade de identificação do sentido e ângu 10 de mergulho das fraturas

4a) a própria imprecisão do mẻtodo.

Um outro método (?) adotado, sobretudo no sul do país, é o da radiestesia ou rabdomancia, baseado en captação extra senso rial de "ondas eletricas" por determinadas pessoas, ditas "sen sitivas". Essas pessoas utilizam como "ferramenta" de traba1ho,va rinhas em forma de forquilha, pêndulos e outros apetrechos que, segundo preconiza o método, auxilia a captação da "onda". Tratase portanto de um mëtodo empirico, absolutamente desprovido de princípios técnicos, não merecendo qualquer comentário. 


\subsubsection{CONSIDERAÇOES GERAIS}

Uma das finalidades präticas da presente pesquisa era a de estabelecer um zoneamento potencial-hidroquímico das äguas subterrâneas do aquífero fissura1, na ärea piloto escolhida.

As diversas tentativas de elaborar um mapa de potenciali dades resultaram infrutiferas, em decorrência da extrema hetero geneidade e anisotropia desse tipo de aqüífero. Em decorrência dessas características, a distribuição dos valores de vazão espe cifica (parâmetro mais representativo da potencialidade do poço) apresentou-se de maneira muito aleatória, com extremas variaçóes entre pontos próximos uns dos outros. Dessa maneira, foi abando nada a idéia de zonear o aquífero fissural em função da potencia 1. idade apresentada pelos poços nele perfurados.

No que concerne a qualidade, foram tentadas duas metodo logias distintas: Ia) a aplicação do programa "trend surface" ou anälise de tendência, a partir de valores do resíduo seco da gua de cada poço; 2a) o mapeamento de iso-residuo secos com base na interpretação subjetiva dos valores pontuais plotados no mapa.

Em decorrência do elevado grau de heterogeneidade do meio, o mapa deduzido da programação da superfície de tendéncia naõ re fletiu, de modo.coerente, as zonas de distintos comportamentos de salinidade. Com efeito, cada valor no mapa de tendência interage com os circunvizinhos redundando numa anälise meramente estatisti ca do comportamento daquele meio, que absolutamente não reflete a verdadeira tendência de micro-regiōes, aproximadamente distintas. Quando se procurou estabelecer correlações entre as causas origi nárias do zoneamento hidroquímico, resultante do método da superfí cie de tendência, não se conseguiu qualquer conclusão lógica. Por essa razão, esse método foi abandonado, não fazendo sequer parte integrante do trabalho apresentado.

O mapa de zoneamento hidroquímico apresentado em anexo, foi então elaborado através de uma anälise dos dados plotados, com interpolação de valores para o traçado das isolinhas de R.S. 
Esse mapeamento objetiva fornecer uma idéia da distribui cäo espacial da salinidade, relacionando-a às possíveis causas de salinização e deveră servir de subsidio na locação de futuros po ços, sobretudo na distribuição de programas regionais.

Deve-se todavia levar em consideração as limitações desse mapa, tendo em vista os seguintes aspectos:

19) a heterogeneidade na distribuição dos pontos d'âgua,a parecendo áreas de maior concentração, como a quadrícula de são Josë do Campestre, com 1 poço por cada $30 \mathrm{~km}^{2}$ e outras de baixa concentração, como a quadrícula de Açu, com 1 poço por $300 \mathrm{~km}^{2}$.

$\left.2^{\circ}\right)$ a extrema variação de salinidade apresentada muitas vezes em pontos muito pröximos; por exemplo, os poços n? 1199 e 1207 no município de Serrinha (RN), distando pouco mais de $1 \mathrm{~km}$ um do outro, apresentaram valores de residuo seco de $22.970 \mathrm{mg} / 1$ e $813 \mathrm{mg} / 1$ respectivamente.

$\left.3{ }^{\circ}\right)$ as diferentes eppocas de amostragem, uma vez que a co leta foi realizada em meses e até anos distintos, ao longo do pe ríodo 1980-85. E bem provâvel então, que alguns poços tenham for necido água, logo após o período de recarga (período chuvoso) en quanto noutros, a coleta tenha coincidido com o final do periodo de estiagem. Essas variações, podem acarretar algumas diferenças decorrentes de flutuaçōes sazonais da salinidade.

$\left.4^{\circ}\right)$ a influência de fatores que atuam localmente, em fun ção da locação do poço. Assim é que um poço locado nas margens de un rio que possua ägua salinizada, pode apresentar elevado teor de resîduo seco, enquanto um outro, na mesma região, porém mais afasta do da influência do rio (recarga) poderä produzir āgua de baixo va lor de R.S.

8.2.2. CONSIDERACOES SOBRE OS RESULTADOS OBTIDOS

Da anảise do mapa de residuo seco, ou zoneamento hidroquí mico, pode-se destacar as seguintes conclusões: 
a) apesar das interferencias dos diversos fatores que atu am local e regionalmente, distingue-se nitidamente duas regiões bem definidas, uma a oeste, com resîduos secos na maior parte, in feriores a $1.000 \mathrm{mg} / 1$ e outra a leste, com resíduos secos superio res a $1.000 \mathrm{mg} / 1$, com predominância dos valores superiores aos $3.000 \mathrm{mg} / 1$.

b) o limite entre essas duas regiôes, corresponde a uma faixa de direçāo aproximadamente NNE, passando por Teixeira,São Mh mede, Ouro Branco, S.Josẻ do Seridô, Angicos e Pedro Avelino;essa faixa corresponde à dorsal moxfológica descrita atrās, que separa as bacias hidrograficas que drenam para leste, daquelas que drenam para norte (rever as figuras 6.11 e 6.12).

c) na região oriental, de maiores salinidades, ocorrem a 1 guns "trends" da salinização, que correspondem a determinados aci dentes morfológicos ou hidrográficos (compare-se com as figuras ${ }^{\circ}$ 6.11 e 6.12). Assim, notamse uma faixa N-S de Sumé a Taperoá, que se localiza no sopë das elevaçoes a oeste, denominadas de Serra dos Cariris Velhos; o altiplano de Campina Grande-Soledade que cor responde ao Planalto da Borborema em sua forma mais preservada, tambëm concorre para as mais elevadas taxas de salinizaçäo; as faixas de dìreção NE-SW passando em Barra de Santa Rosa, Cuitê e norte de Remígio, correspondem âs bacias hidrogräficas de águas salinizadas, dos rios Jacu e Curimatau; no Rio Grande do Norte, to da a regiâo Agreste possui elevada salinidade, coincidindo com as bacias hidrogrâficas, de aguas bastante salinizadas, dos rios Ce ará-Mirin e potengi.

d) na regiäo ocidental, toda a bacia hidrogräfica do Rio piranhas que se localiza no Estado da paraiba (alto curso formado pelos rios piancó e Rio do Peixe) possui baixíssimos teores de sa linidade; para norte, ao receber o rio Pirantias as contribuições da drenagem que se origina na dorsal morfológica de maior aridez, representada principalmente pelas bacias dos rios Seridö e Espinha ras, os valores de R.S. jä ultrapassam os $1.000 \mathrm{mg} / 1$ chegando at $\overrightarrow{\mathrm{e}}$ quase $8.000 \mathrm{mg} / 1$ na faixa NE-SW que passa por Catolé do Rocha, Be lëm do São Francisco, Jucurutu e São Rafael. Na bacia do Rio Apodi mais a oeste, os valores são ligeiramente elevados, flutuando en tre 1.000 e $3.000 \mathrm{mg} / 1$. 
e) em nenhuma das duas regiões, ocorre relacionamento en tre zonas de maior ou menor salinidade, com determinados tipos $1 \underline{i}$ ticos.

8.2.3. CONCLUSOES GERAIS SOBRE O ESTUDO HIDROQUTMICO

Do exposto, pode-se apresentar as seguintes conclusões:

1a) a distribuição regional dos índices de salinidade das äguas subterrâneas em rochas fraturadas, na regiāo semi-ärida do Nordeste do Brasil, é comandada primeiramente pelas condições cli mäticas;

2a) secundariamente, e a nível localizado, desempenham pe pel de realce na salinização dessas äguas, a qualidade das äguas superficiais e o relevo;

3å) a diversificação litológica não exerce quase nenhuma influência, salvo em casos muito localizados, no processo de sali ni.zação;

4ạ) somente a nível local, desempenham incipiente relação com a salinidade, o tipo de fratura e a profundidade em que essas fraturas são interceptadas pela perfuração do poço. A profundidade em que são consideradas pequenas as influências na salinização, $\vec{e}$ no 1 imite do estudo realizado, ou seja, atē $60,0 \mathrm{~m}$; evidentemente, à grandes profundidades, onde as äguas não são renovadas, o proces so de salinização tende a acentuar-se. 
$\mathbb{A} \quad \mathbb{N} \quad \mathbb{E} \quad \mathbb{X} \quad 0 \quad \mathbb{S}$ 
A. 1 - BIBLIOGRA IA CONSULIIADA 
ALBUQUERQUE, J.do P.T. - 1971 - "Inventārio Hidrogeolögico Bäsico do Nordeste" - Folha n` 15 - Jaguaribe-SE - SUDENE - Sërie Hidrogeologia $\mathrm{n}^{\circ} 32,187 \mathrm{pp}$. - Recife-PE

ALMEIDA,F.F.M. de ; BRITO,B.B. de e FUCK,R.A. - 1977 - "Províncias Estruturais Brasileiras" - VII Simp.Geol. do Nordeste da SBG.Campina Grande,PB. Atas pp. 363-391.

ALMEIDA, F.F.M.de; AMARAL, G. ;CORDANI, U.G. e KAHASHITA, K. - 1973 "The Precambrian evolution of the South American Cratonic max gin south of the Amazon River. In: "The Ocean Basin And Margins". Ed. A.E.M. Nairn and F.G.Stehli, Vo1.1 - The South A t1antic : 411-446 - Pergamon Press, New York.

ABREU, F.M.de ;VILLAS, R.N.N. e HASUI,Y. - 1980 - "Esboço estratigrä fico do Pre-cambriano da região de Gurupi, Estados do Pará e Maranhão - XXXI C.ng.Bras.Geol.Camboriu - Anais, Vol.2, pp. $647-658$.

BARBOSA,0. - 1965 - "Geologia das folhas de Remanso e Sento Sẻ , Estado da Bahia" - Rio de Janeiro, PROSPEC/DNPM.

BARTON,N. - 1975 - "Description of Rock Masses, Joints and Discontinuities" - ISRM - Norwegian Geotecnhical Institute - Oslo.

BENEDINI,M. ; GIULIANO,G, ; e TROISI,S. - 1972 - "Alcune considerazioni sulla trattazione matematica del problema del moto in acquiferi fessurati" - Geologia Applicata e IdrogeologiaVo1.VII - Università diBari - Italia.

BRAESTE,C. - 1977 - "Theory of Flow Through Fractures Rocks" - International Seminar - Stockholm - Sweden.

BRITO NEVES,B.B.de - 1975 - "Regionalização geotectônica do Pre c... cambriano nordestino" - Tese de Doutoramento apresentada ao Instituto de Geociências da Universidade de São Paulo. 198pp. BRTTO NEVES,B.B.de - 1983 - "O Mapa Geológico do Nordeste Orien ta1 do Brasil, Escala 1/1.000.000"- Tese apresentada ao Concurso de Livre Docência no Instituto de Geologia da USP CAMPBEL,M.D. - 1977 - "Water We11 Technology for Ground-Water De velopment and Production in Igneous and Metamorphic Rocks"International Seminar - Stockholm - Sweden. 
CAMPOS,M. et al. - 1976 - "Projeto Rio Jaguaribe ; relatôrio final". Recife, DNPM/CPRM, 14 volumes (circulaçāo restrita).

CORDANI,U.G. - 1968 - "Esboço da Geocronologia Pre-Cambríana da América do Sul". In An.Acad.Bras.Cienc. , Rio de Janeiro, 40 (Suplemento): $47-51$.

COSTA, WALDIR D. - 1980 - "Aspectos macro-estruturais que influem na hïrogeologia de rochas cristalinas fraturadas". Seminärio apresentado no Curso de Pós-Graduação da USP-SP.

COSTA, WALDIR,D. - 1980 - "F1uxo atravës de fraturas". Seminärio a presentado no Curso de Pós-Graduação da USP-SP.

COSTA, WALDIR,D. - 1985 - "Avaliação dos critërios de locação de poços em rochas cristalinas". In: I Simpösio Nacional de Agua Subterrânea em Rochas Fraturadas. Belo Horizonte. Anais da ABAS-MG. pp. 133-143.

COSTA, WALTER, D. - 1965 - "Anälise dos fatores que influenciam na hidrogeologia do cristalino". Rev. Agua Subterrânea, 1 (4): $14-47$ - Recife.

COST $\Lambda$, WALTER,D. - 1972 - "Contribuição da mecânica das rochas à e volução estrutural da Serra do Mar" - Anais do XXVI Congres:so Brasileiro de Geologia - Belêm - PA.

CRUZ,W.B.de - 1974 - "Estudo geoquímico preliminar das äguas subterrâneas do nordeste do Brasil". Recife -SUDENE:Sêrie Hidro geologia n:8.

CUSTODIO,E. e LLAMAS,M.R. - 1976 - "Hidrologia Subterrânea".Edici ones Omega S.A. - Barcelona - Tomo I.

DNPM/CPRM - 1980 - "Projeto Scheelita do Seridö" 35 vol. - Recife Publicação restrita).

EBERT,H. - 1955 - "Pesquisas no polígono das secas". In:Departamen to Nacional da Produçäo Mineral, relatōrio da diretoria 1954 , Rio de Janeiro, pp.79-85.

EBERT,H - 1964 - "Tectônica e metamorfismo regional do escudo brasilleiro" - Recife - SUDENE/DG, 49 pp. (circulação interna).

EBERT,H. - 1968 - "Geologia do Alto Seridó. Nota explicativa e fotha geolögica de Currais Novos". Recife,SUDENE, Sërie Geologia Regiona $1,11,120 \mathrm{pp}$. 
HONYK, W.J. - 1979 - "Proposta de uma nova unidade de produção de poço nas rochas cristalinas" - UFPE - Recife (circulação interna e restrita).

JAEGER,J.C. e COOK,N.G.W. - 1968 - "Fundamenta1s of Rock Mechanics" - Methen, London.

KEGEL,W. - 1961 - "Os lineamentos na estrutura geolôgica do nordes te". An.Acad.Bras.Cienc.33: 25-26, Rio de Janeìro.

KEGEL,W. -196.5 - "A estrutura geológica do nordeste do Brasil".Bol. DNPM, Div.Geol.Min. (227): pp. 1-52 - Rio de Janeiro.

LARSSON,I - 1963 - "Tectonic and Morphologic Studies in Pre-Cambrian Rocks at Ground Water Prospecting in South Sweden"-Geo logiska Fo reningens i Stockolm Furhandlingar - Vo1.85 Stockolm.

LARSSON, I - 1967 - "Anisotropy in Pre-Cambrian Rocks and Post Crystalline Deformations Models" - Lund Studies in Geography Ser.A.Physical Geography, n: 38 - Sweden.

LARSSON, I. - 1968 - "Ground Water in Pre-Cambrian Rocks in Southern Sweden" - Pergamon Press - Oxford e New York.

LARSSON,I - 1977 - "Ground Water inHard Rocks" - International Se minar - Stocholm - Sweden.

LEAL,A.de S. - 1968 - "Considerações sobre a circulação de água em rochas cristalinas e salinização em região árida: Area piloto de Juazeiro - Curaça - BA " - Recife - SUDENE: Série Hidrogeo: logia, n:24.

LEgRAND,H. - 1959 - "Ye1d of We11s" - Div.Minera1 Resources, Bu11 n:75 - USA.

Louls, C. - 1968 - "Etude des Ecoulements d"Eau des les Roches Fissurés et de leurs influences sur la Stabilitë des Massifs Rocheux" - These presentêe a 1 "Universitê de Karlerache - E.D.F. Bulletin de la Direction des Etudes et Recherches. Serie A, $n: 3$.

LOUIS, C, - 1974 -. "Fluxo de âgua a três dimensões em rochas fissura das" Tradução n5 da ABGE - São Paulo.

MELLO,A.A.de - 1979 - "Caracterîsticas Geológicas e Metalotectônicas dos CInturōes Môveis do Nordeste Oriental" - Recife, CPRM, 
MABESOONE, J.M. e CASTRO, C.de - 19.75 - "Desenvolvimento geomorfolögi co do Nordeste Brasileirro". Bol, da Sociedade Brasileira de Geologia-Nücleo de Pernambuco. N93 - Recife

MENDES,G.M.de A. e STLVA JUNIOR,H.de 0, - 1980 - "Tdentificação de ăreas passîveis à exploração de ăguas subterrâneas no sertão pernambucano" - CONDEPE - Recife (publicação interna)

MENDONÇA,J.C.G.; CAMPOS,M; BRAGA,A.P.G.; e SOUZA,E.M. - 1982 -"Ca racterização estratigräfica dos metassedimentos da região de Itataia,CE(Grupo Itataia)" - XXXII Cong.Bras.Geo1.-Salvador 1982 Anais, vol I pp.325-338

MEUNIER,A.R, - 1964 - "Sucession stratigraphique et passagens late raux dus au metamorphisme dans 1 a serie Cearâ, antecambrien du nord-est bresilien". Compt-Rendus de $1^{\circ A c a d e m i e ~ d e s ~ S c i e n ~}$ ces, Paris, (259): 3796-3799.

OBERT,L. e DUVAL,W.T.- 1967 - "Rock Mechanics and the Designs of Structure in Rock" - Wiley, N.York

PRICE,N.J. - 1959 - "Mechanics of jointing in rocks". Geol.Mag. 96,149 - London

PRICE,N.J. - 1966 - "Fault and Joint Development in Brittle and Semi-Britt1e Rock" - Pergamon Press, London

QUADROS,E.F.de - 1977 - "Fundamentos da Hidrâulica dos Meios Fissu rados"- Esc.Politêcnica da Universidade de São Paulo - São paulo (circulaçāo restrita)

QUADRoS,E.F.de - 1982 - "Determinação das características do fluxo de âgua em fraturas de rochas" - Tese de Mestrado apresenta da na Escola Politếcnica da USP - SP (circulação restrita)

RAGAN,D.M. - 1968 - "Structural Geology an introduction to geometri ca1 tecniques". John Wiley \& Sons, Inc.- New York- USA

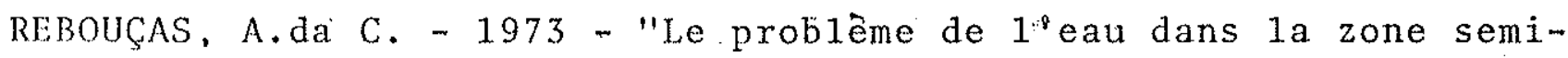
ärida du Brësil". Tese de Doutorado apresentada na Universida de de Strasbourg-França (circulação restrita).

RZHEWSKY,Y e NOVIK,G. - 1971 - "The Physics of Rocks" Mir Publishers Moscou - URRS

SANTOS,E,J,dos - 1977 - "O modelo de evolução precambriana da regi āo de Arcoverde,Pernambuco" - VIII Simp.Geol.do Nordeste da $\mathrm{SBG}$, Campina Grande, 1977, Atas pp 225-245 
SANTOS,E, , dos -1971 "As feiçôes estruturais da folha Arcoverde, pernambuco e o mecanismo dos falhamentos da zona transversa1" Rev.Eng.Miner.Metal $5.3(313): 35-40$ Rio de Janeiro

SANTOS, E,J.dos e CALDASSO, A.L.S, - 1977 - "Sîntese dos confiecimen tos e ensaio interpretativo da ärea de Riacho do Pontal, Nor deste do Brasil". In: Reunião preparatôria para o Simpósio do Craton do Säo Francisco e suas faixas marginais. Anais, Salvador, SME/CPM-BA, Pub1.Esp. 3 , pp 399-426

SCHALLER,H - - 1969 - "Revisäo Estratigrâfica da Bacia Sergipe/A1a goas"- Bo1.Tëcnico PETROBRÁS,12(1):21-86, Rio de Janeiro

SCHLICHTING,H: - 1960 - "Boundary 1ayer theory". 4a ed. New York MC Graw-Hi11 - USA

SEVER,C.W. - 1964 - "Geology and Ground-Watex Resources of Crysta lline Rocks: - Dawson County, Georgia". Geological Survey, Information Circular,30. At1anta, Georgia,USA

SCHOBBENHAUS,C.; CAMPOS,D.de A.; DERZE,G.G.; e ASMUS,H.E.- 1984 "Geologia do Brasil", 501 pp - DNPM-MME

SIDDIQQI,S.H, e PARIZEK,R.R. - 1971 - "Hygrogeologic Factors influ encing Well Yelds in Folded and Faulted Carbonate Rocks in Central Pennsylvania". Water Resources Research. Vo1.7,n95 Siqueira, L - 1963 - "Contribuição da Geologia a Pesquisa de Agua Subterrânea" - SUDENE - Recife

STREeTER,V.L. - 1974 - "Mecânica dos Fluidos" (Trađução). Editora McGraw-Hill do Brasil Ltda,

SUDENE - 1978 - "Plano de Aproveitamento Integrado dos Recursos Hí dricos do Nordeste - PLtRhINE, Fase I". Vol III - Aguas Sub terrâneas. Elaborado pela GEOTECNICA S/A - Recife

SUSZCZYNSKI,E.F.- 1966 - "Consideraçöes sobre a evolução tectonicoorogenêtica da parte oriental do escudo brasileiro". Bol.Rec. Nat. SUDENE 4 (3/4): 371-416 - Recife

WINDLEY,B,F, - 19.78 - "The Evoluing Continents" - Chichester, John Wiley \& Sons, $385 \mathrm{pp}$

ZIENKIEWICZ,O.C, e STAGG,K,G, - 19.68 - "Rock Mechanics in Engine ering Practice", Division of Civil Engineering School of Engineering, University of Wales, Swansea. 
A.2 - CADASTRO DOS pocos 
CADASTRO GERAL DOS POÇOS PERFURADOS NOS ESTADOS DO RIO GRANDE DONORTE E PARAIBA

\begin{tabular}{|c|c|c|c|c|c|c|c|c|c|c|c|c|c|c|c|c|c|c|c|c|}
\hline \multirow{3}{*}{$\mathrm{N} S$} & \multicolumn{2}{|r|}{ DADOS } & $C A C 1$ & 10 & 1 & & & \multirow{3}{*}{\begin{tabular}{|} 
DATA \\
PERFU \\
RACQAC \\
POÇO
\end{tabular}} & \multicolumn{4}{|c|}{ DADOS TECNICOS DO } & \multirow{3}{*}{$\begin{array}{l}\text { POÇO } \\
\begin{array}{l}\text { VAZ } \\
\text { ESPEO } \\
(1 / \mathrm{a} / \mathrm{mI}\end{array}\end{array}$} & \multicolumn{2}{|c|}{ DADOS GEOLOGICOS, } & \multicolumn{2}{|c|}{ FISIOGRÁFICOS } & \multicolumn{3}{|c|}{ HICROQUIMICOS } \\
\hline & \multirow{2}{*}{$\begin{array}{l}\text { NP CAD } \\
\text { ENPRESA } \\
\text { PERFUR }\end{array}$} & \multirow{2}{*}{ LOCALIDADE } & \multirow{2}{*}{\multicolumn{2}{|c|}{ MUNICÍP:O }} & \multicolumn{2}{|c|}{ COORD. GEOGRAF } & \multirow{2}{*}{$\begin{array}{l}0 \\
: 0 \\
0 \\
0 \\
0\end{array}$} & & $\begin{array}{l}\text { PRO- } \\
\text { FUND. }\end{array}$ & & & & & $\forall A$ & MANTO COB & BERT: & & RAS & L. $/$ & 000 \\
\hline & & & & & $\operatorname{con} 6$ & LATIT & & & $(m)$ & & & & & & ATERIAL & ESP & 180 & P4OF INT & & \\
\hline 1001 & 1035 & Santa Isabel & Barcelon & na & 838,8 & 3,2 & or & $07 / 84$ & $60,00 \mid$ & $3,90 / 4$ & 41,97 & 514 & 13 & & Arei & 1,0 & & 3,5 & & 19.8 \\
\hline & 343 & Fiacho & ento & nandes & $\{854,0\}$ & & or & & & & & 4.0 & 332 & & & & & & & \\
\hline & 346 & o & $"$ & & 849,0 & & or & $02 / 81$ & 40,00 & & & 1.180 & 69 & 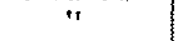 & and & 2.6 & - & 6,3 & & 10 \\
\hline & 471 & Gang & $"$ & $"$ & 58,7 & & or & & & & & 5.535 & 1.569 & $"$ & & 3 & - & 12 & & $3.818,8$ \\
\hline & 527 & Sāo Vicente & $"$ & $"$ & 67,6 & 5,4 & Or & 12 & 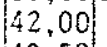 & & & 2.000 & 99 & Gra & Arg & & - & 6, & & \\
\hline & 1245 & Aris & $"$ & $"$ & 854,5 &, 0 & or & 105 & 42 & 0 & & 24.0 & 3.200 & & en: & $\vec{s}$ & 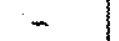 & $4-$ & - & 6,4 \\
\hline & 1047 & Juru & $"$ & $"$ & 870,5 & & Or & $07 / 84$ & 60 & & & & 88 & $G_{\tilde{x}}$ & & Ii, & - & & - & 80,0 \\
\hline & $\begin{array}{l}40 \tilde{3} \\
581\end{array}$ & Lagoa do $P$ & Bon Jesu & & 875,7 & 0 & or & $06 / 81$ & 70 & & & 1. & 41 & & arg & 1 & 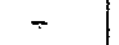 & & & \\
\hline & $\begin{array}{l}584 \\
681\end{array}$ & $\begin{array}{l}\text { Sant } \\
1, a g 0\end{array}$ & $"$. & & 875,6 & & Or & 0.3 & 56 & & & 6. & 272 & & & 5 & - & 7 & & 5,6 \\
\hline & $\begin{array}{l}681 \\
785\end{array}$ & $\begin{array}{l}\text { 1,ago } \\
\text { são. }\end{array}$ & $"$ & 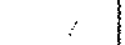 & 881,2 & $0.331,1 \mid$ & Or & 01,83 & 60 & 8 , & & 1. & 68 & $"$ & rents & 8 & . & & - & 30,0 \\
\hline & 8 & $\begin{array}{l}\text { São } \\
\text { Sato }\end{array}$ & $"$ & & 877,8 & 9.3 & or & 097 & 63 & 22 & & & 38 & $"$ & $\operatorname{axg}$ & 7 & - & & & \\
\hline & 83 & S & $"$ & & 4 & & or & 10 & 0 & 4, & & 1.7 & 69 & ito & Arc & 3 & - & & 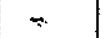 & 2,6 \\
\hline & 918 & II & 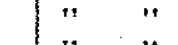 & & 881,4 & & |or & & & & & 2. & 194 & & $\operatorname{arevi}$ & $\sqrt{11}$ & . & & & \\
\hline & 949 & $F$ & $"$ & & 872,4 & 9.3 & $0 x$ & 102 & 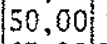 & & & 8.0 & 4.908 & & $\operatorname{ren} \mid$ & 13. & 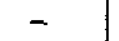 &, 0 & 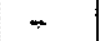 & \\
\hline & 1259 & $G$ & it & & 882,2 & & Or & & & 17, & & 1. & 715 & $"$ & $\operatorname{argh}$ & at; & 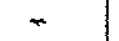 & 26 & & \\
\hline & 1262 & os Bezerros & $"$ & & 882,5 & 9.3 & Or & $07 / 85$ & $0 \mid 1$ & & & 1. & 335 & $\because$ & ii) & 5 & - & & & \\
\hline & 552 & & Brejinho & & 896,9 & 9.3 & or & $02 / 82$ & $|60,00|$ & 3 & 13 & 7.2 & 70 & $\because$ & Ars & 2 & + & 7,0 & 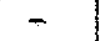 & - \\
\hline & 1 & edonde & & & & & lor & & 60 & & & & & $"$ & & 4, & - & 6,7 & & \\
\hline & 56 & que & $"$ & & & & or & & 0 & 2, & & & 26 & $"$ & $"$ & 7. & - & 28 & 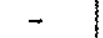 & \\
\hline & 6 & Exu & $"$ & & & & or & 10 & 45 & 8. & & 4.8 .80 & 47 & $"$ & Areia axy & 0,8 & - & & . & \\
\hline & 7 & ria & 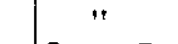 & & 0 & & or & & & & & 8. & 78 & $"$ & & 1 , & - & $5-$ & - &, 4 \\
\hline & 404 & II & Imp & es & & 9. & lor & & & $=0$ & & & 0 & $"$ & $\operatorname{tren}$ & 11,2 & - & & - & \\
\hline & 900 & Sāo & Caiç & & 8 & & for & 01 & 45 & 3 & & 3. & 486 & Micaxisto & Arc & 3 & - & $-16,2$ & - & 15 \\
\hline & 2041 & Rio & & & 835,2 & & Or & 07 & 60,00 & 2, & & 1. & 65 & 1 & Aro & 4 & - & & - & \\
\hline & 385 & Re & erro Co & ora & 801,3 & 0.5 & Or & 05 & 45,00 & 2,902 & $21,22)$ & 5.3 & 281 & Gnaisse & ar. & 2,5 & Tr.Tr. & $6-26$ & TaIv. & 14. \\
\hline & 1147 & Monte Alegre I & & & & & Or & & 0 & - & - & & 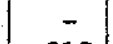 & 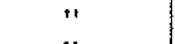 & ren & 1,5 & & & & 47,6 \\
\hline & 1149 & $" I I$ & & & & & lor & & 60 & $8,00 \mid 2$ & 22,0 & 3.0 & 213 & $"$ & & 0,3 & $\operatorname{Tr}$ & $6-$ & $"$ & - \\
\hline & 988 & Pिoca & i & & & & $10 x$ & & & 0 & & & 25 & $"$ & Areia ang & 5,6 & - & & - & 941,6 \\
\hline & & in & & & & & $0 x$ & & & 11 & & & & $"$ & & 10, & - & 15 & - & 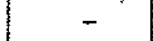 \\
\hline & 3. & Gado & elmo: & arinho & 7 & 19.3 & Or & & & 10 & 35 & 3. & 1. & $1 "$ & $n$ & 1, & - & & - & \\
\hline & 3 & & & & 8 & & $0 x$ & & & & & & & $"$ & ar. & 4 & - & & - & \\
\hline & 6 & & $"$. & &, 3 & & Or & & & 2 , & & & & " & Areia & 4,1 & - & & - &, 4 \\
\hline & 68 & $\mathrm{dac}$ & Japi & & & & $0 x$ & & & 6 , & & 7.2 & 2. & $\because$ & & . & - & & - & 7,6 \\
\hline & 75 & B & & & & & or & & & 2 , & & 3.6 & & Granito & Areia & - & - & & - & \\
\hline & 8 & da Barra & $"$ & & & & $\mathrm{Or}$ & & & & 14 & & & & & 2, & - & & - & \\
\hline & 87 & & & & & & Or & & & 6, & 10 & 3.2 & & $\ddot{* 1}$ & & 4, & - & & - & \\
\hline & $8:$ & & $"$ & & & & Or & & & 6. & & & & $"$ & hrei & 7 & - & & - & $1.966,8$ \\
\hline & 89 & de Baixo & "1" & & & & or & & & 2 , & 5 & 3. & 1.2 & $"$ & arels & 9,0 & - & & - & \\
\hline & 89 & Canoas & & & & & Or 1 & & & 3. & 19,55 & 1.9 & 11 & Gnaiss & Are & 8,0 & - & & - & \\
\hline & 52 & & 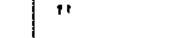 & & & & or & & & & 37 & & 1 & & Eiv & 10. & - & & - & \\
\hline & $3 S$ & Sode & Jamuario & Ciece & & & lor & & & 0 & & 1.1 & 3 & 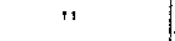 & & $\sqrt{4}$, & - & & - & \\
\hline & & $\mathrm{Ca}$. & ." & & & & or & & & & 5.3 & 1.5 & 7 & $"$ & $\operatorname{Arg}$ & 100 & - & & - & \\
\hline & & & $"$ & 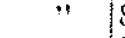 & & & n: 1 & & & & 36, & & 16 & $"$ & & 2,7 & - & & - & \\
\hline & 50 & Bonita & " & 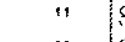 & & & $m:$ & & & & & & & $"$ & Aro & & - & & - & \\
\hline & 5 & & 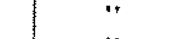 & 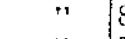 & & & for f & & & 1,201 & 15. & 1.446 & 10 & $"$ & 1 & $j, 7$ & - & 7 & - & 8,8 \\
\hline & 1 & & " & 0 & & & or & & & $2,30 \mathrm{~b}$ & 31,64 & 757 & & $"$ & Areia & 13.0 & - & & - & \\
\hline & 562 & Pro Comprido & $"$ & $\|$ & & & $o r$ & 102 & & 7,73 & $10,22: 3$ & 16.000 & 0.43 & " & hrs.aron? & 2,5 & - & & - & \\
\hline & $50 \hat{4}$ & & $\because$ & $"$ & & & & & & & & & & . & $" t$ & 5 & - & & - & \\
\hline & & & $"$ & & & & & & & & & 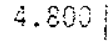 & 210 & " & & & & & 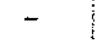 & $4.922,4$ \\
\hline
\end{tabular}


CADASTRO GERAL DOS POCOS PEFFURADOS NOS ESTADOS DO RIO GRANDE DONORTE E PARAIBA

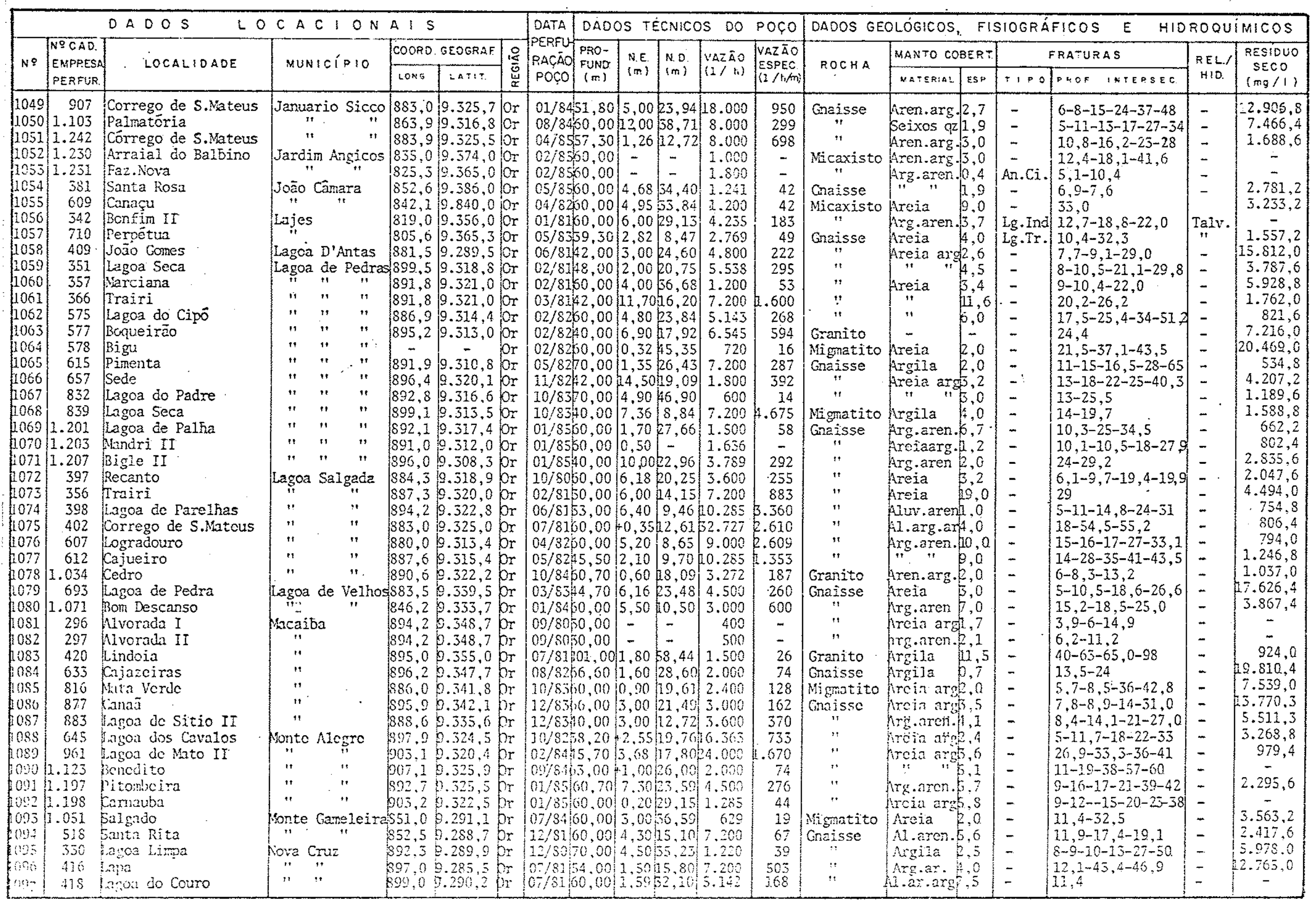


CADASTRO GERAL DOS POCOS PERFURADOS NOS ESTADOS DO RIO GRANDE DO NORTE E PARAIBA

\begin{tabular}{|c|c|c|c|c|c|c|c|c|c|c|c|c|c|c|c|c|c|c|c|}
\hline & & DADOS & $C A C: O . N$ & $A 1 S$ & & & DATA & DADC & OS TE & CNICO & OS 00 & POÇO & DADOS G & Losicos, & Fis & sive & os & U & $\cos$ \\
\hline & & & & COORD. & GEOGRAF & 19 & PERFU & & & & & & & MANTO COE & BERT: & & FRATURAS & $d$ & RESIDUO \\
\hline$N=$ & $\begin{array}{l}\text { EMFRESA } \\
\text { PERFUR }\end{array}$ & 10 & MUN & $10 \mathrm{~s}$ & LATIT & 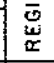 & POÇO & 50 & & & & & $C R A$ & WATERBAL & ESP & 190 & PRDE InTERSEC & & \\
\hline 0 & 419 & Jatobá & Nova Cruz & 839.0 & & Or & $67 / 81$ & & 3,10 & 7,10 & 14.400 & 600 & & & 4,8 & - & 5,2 & & 3700.8 \\
\hline & 456 & Pedra Tapada & $"$ " & 0,6 & & 10r & & & 5,07 & & & & & & $\left\{\begin{array}{l}7,0 \\
7,0\end{array}\right.$ & - & $-26,5$ & & \\
\hline & 493 & Lagoa dos & $"$ & 92,6 & 8 & Or & $11 / 81$ & & 12,2, & & 91 & 36 & ' & & 4,5 & - & -23 & 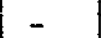 & 9.2 \\
\hline & 496 & Lagoa do lima & " & 85,6 & 7 & lor & $\tilde{I I}$ & & 2 & 17 & 2.7 & 169 & , & & 8,7 & . & $9-26$ & - & 3.0 \\
\hline & 499 & Esperariça & $"$ & 894,7 &, 2 & or & $11 / 81$ & & 2,50 & {$[5,67$} & 4.000 & 313 & $"$ & Aren.arg & 5,2 & - & $-16-17-21-22,3$ & - & $1.733,6$ \\
\hline & 501 & Gravatá & "t & 895,7 & & Or & & & 3,00 & & 3.600 & 458 & 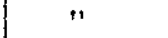 & & 3,3 & - & i & - & 96,0 \\
\hline & 505 & Boqueiräo & $"$ & 894,7 & 3 & $10 x$ & $11 / 31$ & & 9,001 & 34,60 & 1.384 & 54 & $" 1$ & Argila & 5,5 & - & $6-3,2-27,3$ & - & 358.0 \\
\hline & 531 & Campus Univer & $"$ & 594,2 & 0 & $10 \mathrm{r}$ & & & $1,70 \mid$ & 36,00 & 3.000 & 87 & $"$ & arg & 2,0 & - & $-11,5-39,2$ & . & $3.501,2$ \\
\hline & 674 & N.Sra.da Cono & " & 905,3 & & jor & & & I, & & & 1 & $"$ & & 1,4 & _- & 2, & - & 102 \\
\hline & 1.049 & Faz.Catole & $"$ & 893,0 & 2,7 & Or & $07 / 84$ & 46,00 & 6,70 & 24,20 & 1.384 & 79 & 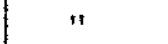 & Aren.arg & 2,2 & - & 30 & - & $1.710,0$ \\
\hline & 1.236 & Cajazeiras & $"$ & 887,6 & & or & & & & & & 15 & 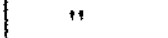 & & I, 5 & - & & - & \\
\hline & 1.244 & Lagoa Limpa & & 894,1 & 6 & Or & & & 0,40 & & 701 & 22 & $"$ & ren. & 3,2 & - & $7-37-40-41$ & - & 6.6 \\
\hline & 291 & Lanoa dos Se & ras: & 901,3 & 1 & Or & bo & & 6,70 & & 6.000 & 654 & . & la & 2,2 & - & $-10-11,2-11,9$ & 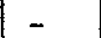 & 0.0 \\
\hline & 833 & São Fedro & Pedr & 82 & & or & & & & & 2.000 & 87 & & $\arg$ & 4,1 & $\mathrm{Ag}$ & -7 & $T$ & \\
\hline & 834 & Canto Comprido & $"$ & 8 & 7 & or & 管 & & $34,00 \mathrm{~s}$ & 48,08 & 3.000 & 735 & & Arg & 2,8 & Tr.Tr. & -15 & & 20,0 \\
\hline & 412 & Porteira & Pedr & & & Or & & & $+3,80$ & & 10.000 & - & in & $\arg$ & $h, 5$ & - & 20 & - & 6,4 \\
\hline & 414 & Coite & & & & or & & & & 50,67 & & 30 & & & 3,7 & - & & - & \\
\hline & 661 & Ponza & Poç & 862,4 & 4 & or & & & 31.50 & & 52. & 851 & un & his & $\tilde{3}, 5$ & - & -36 & - &, 2 \\
\hline & 399 & Lagoa Limpa & Pres & 876,0 & & or & & & & & i) 2.3 & 8 & $"$ & & 6,7 & - & & - & 8,4 \\
\hline & 624 & Lagoa de Dentro & & 875,5 & & Or & & & $6,80 \mid$ & & 1. & 6 & 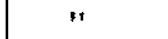 & Ar & 7,5 & - & 0,5 & - & 551,2 \\
\hline & 625 & logradouro & " & 870.0 & & Or & & & 21,25 & & $5) 1$. & 35 & $"$ & $A x$ & 120,3 & - & $12-4$ & - & 2. \\
\hline & 26 & Lugoa d & $"$ & 87 & & or & & & $|-2,71|$ & 43 & & & 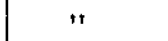 & Areia ard & 4,5 & - & & - & 1.504 \\
\hline & 763 & Freitas III & $"$ & $8:$ & & or & $p$ & & 3,15 & 8,23 & 3.272 & 644 & & Areia & 1,7 & - & -11 & - & 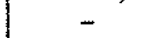 \\
\hline & .006 & Catolê & $"$ & 8 & & or & & & 12,10 & & 61.1 & 57 & & ren. & 10,4 & - & -29 & . &, 9 \\
\hline & 1.009 & Cacimba de Baixo & $"$ & 7 & & or & & & $i$ & & a) 3. & 189 & & ren. & 3,2 & - & & - & \\
\hline & 1.010 & Ретоba & $"$ & 87 & & or & ps & & 4,40 & & 412.000 & 394 & "t & rg. & 4,2 & - & -47 & - & $4.152,2$ \\
\hline & 77 & Serra Caiada & & & & for & & & 11,90 & & 2. & 3.117 & Gra & arg & 0,9 & - &, 5 & - & - \\
\hline & 804 & Ligoa Nova II & Fiac & 3 & & or & p. & & 6,20 & & 56 & 500 & & hren.arg. & 4,3 & - & & - & 220,0 \\
\hline & 80 & Lagoa Nova III & & & & $10 x$ & & & 15 & & 36 & 35 & & & 2,0 & . & -24 & . & \\
\hline & 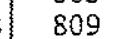 & Nova IV & & & & $0 T$ & & & & & 3 & 8 & $"$ & & 1,3 & - & & - & 0 \\
\hline & 2 & da Brilh & Santa & & & Or & & & 19,10 & & 12 . 2 . & 34 & : & & 4,0 & - & 2,2 & - & 22,8 \\
\hline & 46 & Chapada II & & & & $O x$ & & & 0 & & Q 6.0 & 5 & $"$ & $"$ & $h, 2$ & 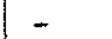 & 2,8 & - & 1,6 \\
\hline & & & n & & & $0 r$ & & & 2 & & Q & .22 & " & Areia & 6,7 & - & & - & 8,4 \\
\hline & & quim & $"$ & & & Dr & & & 3 & & 07.200 & 75 & " & & 5,9 & Tr.Tr. & s & Talv. & $4.848,0$ \\
\hline & 78 & Angoj & " & & & or & & & 1 & & 2) 1.8 & 112 & & Areia an & 88,0 & N.Car. & & & \\
\hline & & & $"$ & & & or & & & & & 2. 1 & 6 & & & 3,4 & - & & - & \\
\hline & 79 & & 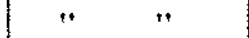 & & & or & & & 3 & 2 & 0 & 4 & & $"$ & 5,7 & & & & 20 \\
\hline & 975 & S. Geraldo & ra & & & or & & & & & 1.6 & 2 & $"$ & $"$ & 5,0 & & 1 & & \\
\hline & $7=$ & & 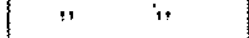 & & & & & & 9 & & o) 2.5 & 9. & $"$ & $"$ & 2,2 & Tr.Tr. & & Vis & \\
\hline & 32 & Preá & tonio & 88 & & or & $=2 / 30$ & Fo & $\mid 12,24$ & 47,48 & 514 & 1 & 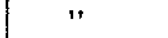 & $" 1$ & 2,0 & - & 4. & - & 29,6 \\
\hline & & $\mathrm{Caj}$ & & & & $b x$ & & & 4,00 & 31,48 & 3.0 & 1 & $"$ & $"$ & 2, & . & & & \\
\hline & & no & 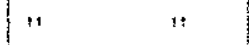 & & & $b_{r}$ & & & 1,20 & & & 5 & 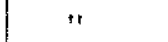 & & 2 & 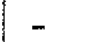 & 17 & - & 6,0 \\
\hline & 50 & I.ajir & "1 & & & or & $13 / 82$ & 50,00 & 2,97 & 8,22 & & 6 & . & Al.arg at & $+9,0$ & - & 1 & - & 2,0 \\
\hline & 62 & Serr & $"$ & & & $b_{0}$ & & & 1. & & & 9 & 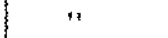 & & 13 & - & & - & \\
\hline & 62 & Kel & " & & & $\mathrm{b}_{3}$ & & & 1, & & & 165 & $"$ & en. & 2 & - & & - & 8.8 \\
\hline & 80 & Ari & it. & S: & & $\mathrm{br}$ & $11 / 53$ & : 8 & 7,10 & & 31.1 & 62 & to & Arg.aren & 1,5 & - & 24 & - & 4 \\
\hline & 410 & Michola & $"$ & & & $p r$ & $6 / 31$ & 60.00 & 1,00 & It & 4. & 300 & Graiss & A1.ar-ang & 1,2 & - & & - & \\
\hline & 60 & ingos do Timi & $"$ & & & 6 & & & & & & .305 & & & & & & & \\
\hline & 24 & Imana & & & & & & & & & & 4 & & & & & & & \\
\hline
\end{tabular}


CADASTRO GERAL DOS POCOS PERFURADOS NOS ESTADOS DO RIO GRANDE DO NORTE E PARAIBA

\begin{tabular}{|c|c|c|c|c|c|c|c|c|c|c|c|c|c|c|c|c|c|c|c|}
\hline \multirow{3}{*}{$\mathrm{N}=$} & \multirow{3}{*}{$\begin{array}{l}N \text { NCAD. } \\
\text { ENARESA } \\
\text { PERFUR. }\end{array}$} & \multirow{3}{*}{$\frac{\text { OAOOS }}{\text { LOCAL }}$} & \multirow{3}{*}{$\frac{C A C: O N}{\text { MUN1CIOIO }}$} & A I S & & \multirow{3}{*}{ 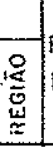 } & \multirow{3}{*}{$\begin{array}{l}\text { DATA } \\
\text { PERFU } \\
\text { RAÇĀO } \\
\text { POÇO }\end{array}$} & \multicolumn{4}{|c|}{ DADOS TÉCNICOS DO } & \multirow{3}{*}{$\begin{array}{l}\text { POÇO } \\
\text { VAZÃO } \\
\text { ESPEC } \\
(1 / \mathrm{B} / \mathrm{m})\end{array}$} & \multicolumn{2}{|c|}{ DADOS GEOLÓGICOS, } & \multicolumn{2}{|c|}{ FISIOGRÁFICOS } & & \multirow{3}{*}{$\begin{array}{c}R E L . / \\
H 1 D .\end{array}$} & IMICOS \\
\hline & & & & \multicolumn{2}{|c|}{ COORO. GCOGRAF } & & & & & & & & OCHA & MANTO CO & 8हR: & & FRATURAS & & RESIOUO \\
\hline & & & & LONS & rir & & & $(m)$ & & & & & & $2 \mathrm{~L}$ & EsP & $\circ 0$ & PROF in & & $(\mathrm{mg} / \mathrm{l})$ \\
\hline & 1.243 & Capim Açu & Santo & 886,3 & 297,4 & or & $04 / 85$ & 60,00 & 7,50 & 25,60 & 1.894 & 305 & & Ten.arg & 7,0 & & 9,8 & 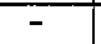 & $5.348,4$ \\
\hline & 230 & São Domingos II & $"$ & 9.8 &, 4 & Or & 80 & & - & - & & - & & & 5,0 & 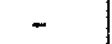 & 0 & - & \\
\hline & 236 & $\| \quad " \quad$ III & $"$ & .8 &, 4 & or & 180 & & 11,25 & 25,90 & 2.769 & 189 & $"$ & & 2 & 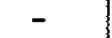 & $12,8-23,0$ & & $51.125,2$ \\
\hline & 237 & $"$ IV & $"$ & 869,8 & 9.513 .4 & Or & $06 / 80$ & $40,00)$ & 6.68 & 20,20 & 4.800 & 355 & $"$ & Arg & 6,6 & - & - & & $7.050,0$ \\
\hline & 240 & Regalia III & $"$ & 866,0 & 08.6 & $\operatorname{lor}$ & $106 / 80$ & & 7,05 & 35,00 & & 18 & $"$ & & & - & $10-18-19-20-28,5$ & - & 7.6 \\
\hline & 500 & Bico Doce & Campestrs & 861,5 & 9.285 .3 & or: & $11 / 81$ & $60,00 \mid$ & 3,20 & 8,27 & 3.000 & 591 & $"$ " " & & 0,4 & - & $6,9-15$ & - & $19.732,0$ \\
\hline & 504 & Quixaba & $" 1$ & 864,5 & $9.297,4$ & or & $11 / 81$ & & 13,74 & 32.77 & 900 & 47 & it & a arg & 2,0 & - & $7,2-33,7$ & - & 06,4 \\
\hline & 506 & Pedra Lisa & $" \quad "$ & & & Or & & & 4,00 & 25,67 & 1.074 & 49 & $"$ & & 1,4 & - & $30,8-2$ & - & \\
\hline & 511 & Toco Preto & $" n$ & 860,5 & $9.290,6$ & Or & $131 / 81$ & $48,00 \%$ & 10,15 & 20,51 & 1.500 & 345 & $"$ & El.ar.ag & 1,5 & - & $10,7-17,5$ & - & 4,0 \\
\hline & 716 & Marcaça II & $" n$ & $871,0\}$ & 05,2 & Oor & $06 / 83$ & 00 & $3,20,1$ & 19,55 & 782 & 47 & $"$ & .arg & 2,0 & - & 253 & - & 0,8 \\
\hline 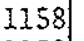 & 770 & Serra Verme & $" n$ & $|863,3|$ & & $10 \mathrm{r}$ & $08 / 83$ & & 2,90 & 10,07 & 6.545 & 912 & $" 1$ & Ars & 5,4 & . & $5-17,2-$ & - & \\
\hline & 773 & Marcaça & $" n$ & 871,8 & 9.303 .1 & Or 1 & $08 / 83$ & 60,00 & 3,13 & 13,83 & 6.545 & 611 & $"$ & Aren.arg & 6,5 & - & 14,5 & - & 5,6 \\
\hline & 780 & Curralinho & 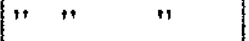 & 854,3 & 4,1 & or & $08 / 83$ & 0 & 7,00 & 24,37 & 1.384 & 80 & $"$ & 110 & 3,2 & - & 55 & - & \\
\hline & 783 & Jacu do Orfä́o & $" n$ & 853,3 & & Or & $09 / 83$ & & 5,70 & 21,84 & 2.000 & 124 & $"$ & Areîa & 4,4 & - & $11,0-13,2-22,3$ & - & 30,8 \\
\hline & 1.187 & Volta do Rio I & $" n$ & 871,3 & $9.301,3$ & Or & $01 / 85$ & 45,60 & - & - & 14.400 & - & $"$ & Aren.arg & 1,8 & - & $4-6-9-19-2$ & - & 7,0 \\
\hline & & Volta do Rio II & $" \|$ & 869,2 & & Or & $01 / 85$ & & 5,55 & 6,03 & 8.000 & 16667 & $"$ & & 5,7 & - & -18 & - & \\
\hline & 1.270 & São Geraldo & $" n$ & & & Or & 0 & & 2,00 & 16,64 & 5.142 & 364 & ". & " & 3,5 & - & 8 & - & $1.270,4$ \\
\hline & 442 & Sede & S.Paulo Poten & 859,3 & 6,4 & $0 \pi$ & $0 S / 81$ & & 18,00 & 45,10 & 27 & 12 & $"$ & Areia & 5,0 & - & & - & - \\
\hline & 686 & Boa & $11 " 11$ & 861,4 & & Ori & 102) & & & & 6.000 & 98 & $"$ & $\arg$ & 3,0 & - & $5-8-10-15,6-25,9$ & - & - \\
\hline & 1.064 & Maria & $" \|$ & 866,2 & 0 & $0=$ & $07 / 84$ & & 17,90 & 20,35 & 1.674 & 683 & $"$ & Aren.arg & 3,0 & - & 75 & - & - \\
\hline & 1.066 & Mang & $" \quad "$ & 866,3 & 7 & or & $|07 / 84|$ & & 1,55 & 33,28 & 1.028 & 32 & $"$ & & 1,0 & - & & - & $3.215,2$ \\
\hline & 691 & Sáo. & $" n$ & 862,9 & & $0 \mathrm{r}$ & 10 & & 1,00 & 15,14 & 5.5 & 392 & $"$ & Are & 6,2 & - & 7 & - & 2,4 \\
\hline & 1.067 & Caba & $" n$ & 865,4 & 6,1 & Or & $07 / 84$ & 60,00 & 3,00 & 26,04 & 2.000 & 83 & $"$ & aren & 3,0 & - & $5-2$ & - & $4.450,0$ \\
\hline & & heisco & 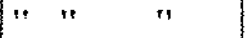 & 854,2 & 8 & or & $104 / 85$ & & - & - & 00 & - & $"$ & arg & 11,8 & - & -59 & $=$ & - \\
\hline & 7 & Santo Estevão & " & 864,5 & 3,5 & $\mathrm{Or}$ & $07 / 85$ & 34,80 & 1,00 & 5,44 & 12.000 & 2.703 & $"$ & & 3,3 & - & $9,6-15,4-26,5$ & . & 65,2 \\
\hline & 269 & II & $" n$ & 866,7 & $9.558,6$ & or: & $107 / 85$ & & 5,50 & 30,12 & 4.500 & 183 & Gran & Ars & 2,0 & - & 17 & & 2 \\
\hline & 290 & Mara & Säo Pedro & . & & Or & $09 / 80$ & & 12,00 & 18, & 8.000 & 1.159 & & & 1 & 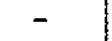 & $5-9-11-16-28$ & -32 & 8,0 \\
\hline & 334 & de Feijāo & $12 "$ & 870,5 & $9.356,5$ & or & $12 / 80$ & & 0,00 & 18,30 & 4.800 & 262 & &. $\mathrm{ag}$ & 2,8 & - & & - & 1,6 \\
\hline & 507 & do Canto & $" \quad "$ & 873,8 & & Or & 11 & & 3,80 & $7: 93$ & $4: 500$ & 1.089 & $"$ & aren. & 5,0 & - & & - & .8 \\
\hline & 500 & do $\mathrm{Ma}$ & $"$ & 871,2 & & Or & $11 /$ & & 2,20 & 3,32 & & & $"$ & Are & 3,0 & 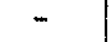 & 25,6 & - & 7,8 \\
\hline & 529 & aimeira & $"$ & 886.2 & 9.3 & 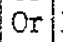 & $12 / 81$ & & 7,80 & 10,64 & 0 & 2. & $"$ & & 3 & - & & 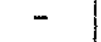 & \\
\hline & 708 & & $"$ & & & or & & & 12,85 & 17 , & 3.000 & G13 & $"$ & Aren.arg & 6,9 & - & & - & $5.700,0$ \\
\hline & 737 & ào I & џ & , 1 & & Or & 0 & & 8,37 & 18,7 & 2.1 & 21 & $"$ & & 1,4 & - & 5 & & - \\
\hline & 758 & Serr & $"$ & 880,9 & 9. & or & 07 & & 6,40 & 9,92 & 3.272 & 929 & $"$ & $"$ & 5,0 & & 4 & - &, 2 \\
\hline & 1.070 & de Sta. & São Tomé & 808,1 & & Or & & & - & - & 1. & - & $\cos$ & Areia & 0,2 & $\operatorname{Lg}$ & 22, & Talv & 006,8 \\
\hline & .250 & de Fo & $"$ & 819,2 & 9) & or & 106 & 60,00 & 2,12 & 24,28 & 1.200 & 54 & & Aren.arg & 3,0 & N.Car. & 7 & Vert. & - \\
\hline & 547 & Tano & Sen.Eloi & 872,8 & $(, 1)$ & or & $02 / 82$ & & 3,20 & 8.21 & 3.600 & 710 & & & 1,5 & 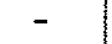 & 0 & - & \\
\hline & .134 & ira & & & & Or & & & & & 3.600 & 501 & & & 2.5 & - & 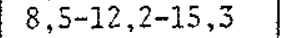 & - & \\
\hline & 440 & es & Serra & 858,1 & 0 & or & $08 / 81$ & 8. & & $64,0 d$ & 600 & 9 & Gran & en. & 3.0 & - & & - & 5,6 \\
\hline & 274 & erozinha III & Serrinhas & 876,3 & & or & $|08 / 80|$ & & 4,60 & 8,03 & 7.200 & 2.087 & & $\arg$ & 5, & - & & 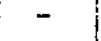 & \\
\hline & 3. & & & & & or & & & 9,602 & 22.0 & 3.150 & 250 & & ren & 4, & - & & - & \\
\hline & 3 & & $"$ & & & on & 05 & & & 22,98 & 6. & 390 & 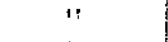 & $\therefore a g$ & 8.0 & - & 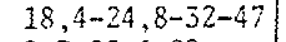 & - & \\
\hline & 423 & 30 & $"$ & 889,1 & .4 & orl & $07 / 81$ & & 2.00 & 32,00 & 2.400 & 8 & $\because$ & Aren.arg & 1.7 & - & & - & \\
\hline & $42-3 x-3$ & Ẽo & $"$ & & & orl & $07 / 31$ & & 2,30 & 14,33 & 3.428 & 27 & $"$ & & 1,7 & - & & - & \\
\hline & 429 & $\operatorname{dos} 0$ & $"$ & $89.5,0$ & & $0 \times 10$ & $|07 / 81|$ & 45,70 & 2,002 & 22,28 & $2.05 i$ & 101 & " & & 4,0 & 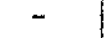 & $\Rightarrow 00.20-42$ & - & \\
\hline & 445 & Arag & $"$ & 870,4 & & 0.0 & $08 / 81$ & & 4,30 & $8,1 \mathrm{~A}$ & & 3.14 & $"$ & $"$ & 2 & 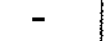 & & - & 6.99 \\
\hline & $4 A_{4}$ & in & " & $\$ 85$ & & Or & $08 / 81$ & & $-2,452$ & $26.2 f \mid$ & 6.000 & 209 & $"$ & & 0,5 & - & $2 \%$, & - & \\
\hline & 450 & m & " & 885. & & 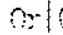 & $100 / 81$ & & 9.9 & .55 .60 & 1.5 & 6.5 & $"$ & & 2.01 & - & $15,28-47,5$ & - & \\
\hline & 452 & fanm andos & & & & $\mathrm{Or}$ & $00 / 81$ & 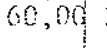 & & & & 123 & & $c n$ & & & & & \\
\hline
\end{tabular}


CADASTRO GERÁL DOS POCOS PERFURADOS NOS ESTADOS DO RIO GRANDE DONORTE E PARAIBA

\begin{tabular}{|c|c|c|c|c|c|c|c|c|c|c|c|c|c|c|c|c|c|c|c|}
\hline \multirow{3}{*}{ NQ } & \multirow{3}{*}{$\begin{array}{l}\text { NOCAO } \\
\text { EMPRESA } \\
\text { PERFUR. }\end{array}$} & \multirow[t]{3}{*}{$D A D O S$} & \multirow{3}{*}{$\frac{C A C I O N}{\text { MUNICIP10 }}$} & \multirow{2}{*}{\multicolumn{2}{|c|}{ COORD. GEOGRAF }} & & \multirow{3}{*}{$\begin{array}{l}\text { OATA } \\
\text { PERFU } \\
\text { RACAOO } \\
\text { POCYO }\end{array}$} & \multicolumn{4}{|c|}{ DADOS TÉCNICOS DO } & \multirow{3}{*}{$\begin{array}{l}P O C C O \\
V A Z \bar{A} O \\
\equiv S P E C \\
(1 / \mathrm{h} / \mathrm{m})\end{array}$} & \multicolumn{2}{|c|}{ DADOS GEOLÓGICOS, } & \multicolumn{2}{|c|}{ FISIOGRÁFICOS } & & \multirow{3}{*}{$\begin{array}{c}R E L / / \\
H I D .\end{array}$} & Micos \\
\hline & & & & & & \multirow{2}{*}{ 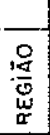 } & & PR.O- & & & & & & MANTO COB & BER: & & FRATURAS & & RESIOUO \\
\hline & & & & :ONG & $\therefore A T T$ & & & & & & & & & VATERIAL & EsP & 190 & DROF INTERSEC. & & \\
\hline 7 & 453 & acho o & Serrinha & & & $O r$ & $09 / 81$ & 47,00 & 0 , & & 00 & 831 & & Nreia & 5,3 & - & $\sqrt{1-12-2}$ & 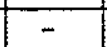 & .6 \\
\hline & 599 & nfim & & & & $O x$ & 182 & & & & & 655 & & & & & & & \\
\hline & 566 & Jacunirim & $\pi$ &, 2 & 7.2 & or & 82) & & & & & 17308 & 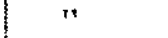 & $"$ & & & & - & \\
\hline & 630 & Amo & " & & 6.0 & Or & $07 / 82$ & .00 & 9.15 & 21 & 2.000 & 157 & & $"$ & & &, $5-2$ & - & \\
\hline & 692 & Nonte Alegre & $"$ & & 17,9 & $\mathrm{Or}$ & $02 / 83$ & & & & 750 & 29 & Mig & $"$ & & & 20 & - & \\
\hline & 813 & Ceäro & $"$ & & & Or & 83 & & & & 10.285 & 2.260 & & Areia ag & & & $5-29$ & - & \\
\hline & 859 & Jacumirim II & $:$ & 3,6 & 6,6 & Or & $11 / 83$ & & & & 535 & 18 & & $\mathrm{Ar}$ & 3,0 & 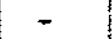 & 71 & - & \\
\hline & 1.050 & Eon & " & & & Or & $07 / 34$ & & & & 1.800 & 1.071 & &. $\operatorname{ag}$ & & 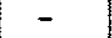 & 3 & - & 04,0 \\
\hline & & Cedr & " & & 505,4 & Or & $08 / 84$ & & & & 2.571 & 120 & & Aren.arg & 4,0 & & & - & 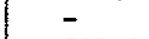 \\
\hline & 39 & Piment: & $"$ & & 310,8 & Or & $04 / 85$ & & 1,50 & & 6.545 & 371 & $"$ & & 1,0 & & $8-$ & - & 501,0 \\
\hline & 80 & Bon & $"$ & & & or & $04 / 85$ & & & & 2.571 & 164 & ' & & 2,5 & & $7=7$ & - & 813.0 \\
\hline & 760. & São pedro II & Sitio Novo & & & Or & $08 / 85$ & & & & $2.5 \pi$ & 185 & 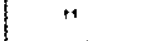 & & 5,7 & & & - & $6.109,2$ \\
\hline & 428 & Mntão & Taipú & & 4.4 & Or & $\mid 08 / 81$ & & & & $1.000\}$ & 36 & Gro & & 13, & - & 1 & & \\
\hline & 528 & Lago & & & & $\mathrm{Or}$ & $12 / 81$ & & & & 1.800 & 90 & & & 1,8 & 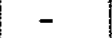 & $-35,1$ & - & 00,0 \\
\hline & 634 & Ch & $"$ & &, 3 & $\mathrm{Or}$ & 08782 & & & & 2.250 & 256 & & a. $\cos$ & 9 & - & 12 & - & 0,4 \\
\hline & 372 & II & Tangará & & & $O r$ & $|03 / 81|$ & & & & 3.600 & 329 & & $\arg$ & 1 , & - & 12, & - & - \\
\hline & 689 & ge & & & & Or & 02783 & & & & 1.894 & 80 & & & 6 & - & -37 & - & 5.4 \\
\hline & 1.037 & Baixa do Ro & $"$ & & & or & $|07784|$ & & & & 12.000 & 2.080 & 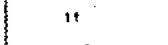 & Are & 3 & - & & & \\
\hline & 1.252 & Pas & $1 "$ & & & or & 0 & & & & 500 & 13 & Gro & $\arg$ & I, & - & $5,2-8,6-15,2$ & - & - \\
\hline & 1.272 & Preto & " & & & or & $08 / 85$ & & 15,90 & & 1.000 & 59 & 6 & & 1, & 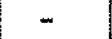 & 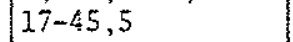 & - & 18,0 \\
\hline & 29.4 & $C_{2 j}$ & Vลarze & & & or & $09 / 80$ & & & & 2.600 & 57 & & en: & & - & & - & \\
\hline & 353 & & 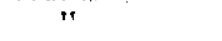 & & & $0 x$ & $02 / 81$ & & & & 3.1 & 248 & 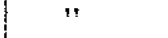 & & 3 & & $1-2$ & - & 3,2 \\
\hline & $-x=1$ & $\mathrm{M}$ & Vera Cru: & & & Or & 0. & & 15, & & 3.6 & 232 & 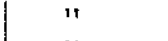 & & & - & & - & 0,0 \\
\hline & 38 & Jac & $" \quad "$ & & & $0 r$ & 03 & & & & 7.2 & 766 & & & 1 & & 0, & - & \\
\hline & 38 & do Jaca & $"$ & 7 & & $\mathrm{Or}$ & 05781 & & 14,60 & 6) & 6.5 & 980 & 1 & Arg.aren & 1,4 & & & - & 5,2 \\
\hline & $38 \mathrm{~S}$ & osê & $\bullet$ & & & Or & 105 & & & & & 750 & 1 & & 113 & - & $6,6-44$ & - & 5,0 \\
\hline & 521 & Genipapo $\mathrm{I}$ & $"$ & 1 & & Or & 12 & & & & & 194 & 1 & & 6,8 & & $6,6-3$ & - & \\
\hline & 525 & $"$ II & $"$ & 2 & & $\mathrm{Or}$ & 81 & & 3,15 & & & 236 & 1 & Aren.arg & 18 & & & - & 2 \\
\hline & & anta & in $>2>$ & & & Or & 0. & & 5 , & & & 5 & " & & 7 & - & -44 & 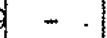 & 35,4 \\
\hline & 66 & $r^{2}$ & , & & & Or & 1] & & & & & 329 & & & & & & 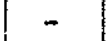 & - \\
\hline & & $a+6$ & 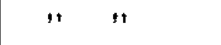 & 896,0 & & $0 x$ & 85 & & 0,50 & & & 104 & & ien & 9,4 & & & & \\
\hline & 1.196 & Ponta de Varz & & 890,3 & & $\mathrm{Or}$ & $01 / 85$ & 70 & 2,09 & 22,02 & 4.500 & 225 & & aren & & & $2=, \infty-\pi$ & & 1,6 \\
\hline & 378 & inturas & Acari & 757,0 & 5 & $O C$ & {$[0.4 / 81$} & 40,00 & 0,80 & 16,45 & 2.880 & 184 & Grani & $"$ & $(3,7)$ & & $4,8-13-14-16-19$ & Elev: & $1.418,6$ \\
\hline & 772 & & & 762,2 & & $O c$ & $08 / 83$ & $45,50+$ & $+0,90$ & 24,72 & 1.200 & 46 & & Ar. & $2, i$ & & & & 1,2 \\
\hline & 1.274 & Sol & $"$ & 765,9 & & $0=$ & $08 / 85$ & 58,70 & - & $=$ & 450 & - & Micax & & 5,2 & & & & - \\
\hline & 1.276 & Sols & $"$ & 765 & & $0 c$ & $08 / 85$ & & & & 986 & 29 & & & 4,7 & & & & - \\
\hline & 1.277 & $\mathrm{Ri}$ & $"$ & 766 & & Oc & $08 / 85$ & & & & 1.575 & 74 & & & & & $21-24$ & HTa & \\
\hline & 340 & Pelo S & Angicos & 792 & & $\alpha c$ & $01 / 81$ & 60 & 5 & & 2.250 & 114 & Grai. & & 5,5 & & & & 2,2 \\
\hline & & Cacimba de Cina III & & & & cc & $02 / 81$ & & & & 615 & 27 & & & & & & & 5,2 \\
\hline & 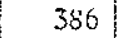 & Sẵo & $"$ & 76 & & $\infty$ & $|05 / 81|$ & 46 & & & $10.285 \mid$ & 5.240 & Micax & & 4, & & $32 \pi$ & & 3,6 \\
\hline & & & $"$ & & & oc & $12 / 81$ & & 3 & & 2.250 & 167 & & en. & 4.0 & & & & \\
\hline & & & " & & & o & & & & & & 13 & ". & & & & 7 & & 5,6 \\
\hline & 5.38 & 1 & " & it & & nc & $01 / 82$ & & & & s.mol & 114 & 6 & & 2 & & $-43-47 \mid$ & & 7.2 \\
\hline & & $\operatorname{Con}$ & $"$ & 765,2 & & $\alpha$ & $01 / S 2 !$ & & & & 1.500 & 43 & Graisse &.$a r$. & 0,9 & & & & \\
\hline & & to & $\because$ & 779,8 & & $0-1 \quad-1$ & $01 / 82$ & & & & 1.800 & 77 & & Areia & 0,8 & & $34 ; 81$ & & 4,0 \\
\hline & 342 & & $"$ & 784 & & & & & & & $1.41]$ & 55 & 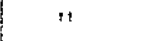 & AD: & 3.0 & & 9 & Talv. & 7,2 \\
\hline & 938 & Srosa 11 & & 778,0 & & $e^{i}$ & 02 & & 4.7. & & 3.000 & 855 & & & 0,3 & & $2-$ & s. & \\
\hline & $2 \because 3$ & 19us & Gajco & 725,3 & & & & & & & 97 & 53 & & & & & & & \\
\hline & & Aarid Alegre & & & & & & & 3,0 & & $\cdots$ & 1 & & & 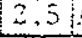 & & $2-15-30-45.3$ & & 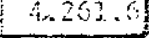 \\
\hline
\end{tabular}


CADASTRO GERAL DOS POCOS PERFURADOS NOS ESTADOS DO RIO GRANDE DO NORTE E PARAIBA

\begin{tabular}{|c|c|c|c|c|c|c|c|c|c|c|c|c|c|c|c|c|c|c|c|c|}
\hline & & $D A D O S$ & $C A C 1 O N$ & 15 & & & DATA & DADO & OS TÉ & CNICO & OS DO & POÇO & DADOS GEO & OLÓGICOS, & is & A & FICOS & $110 F$ & ROQUI & 1005 \\
\hline & NOCAD. & & & COORD. & GEOGRAF & 18 & PERFLY & P5O- & N.E. & N. 0 & $V A \bar{C} \bar{A} O$ & $A Z \overline{A O}$ & & MANTO CO & $8 E R T$ & & FRATUR & & 6 & RESIDUO \\
\hline NO & $\mid \begin{array}{l}\text { EMFRESA } \\
\text { PERFUR }\end{array}$ & & NUNICIPIO & LONG & $\{A \div 1 \%$ & 亲 & Poço & $\{\mathrm{m}\}$ & $(m)$ & $(m)$ & $(\mathrm{n})$ & & HA & $20 \div 5 \operatorname{Ri\Delta L}$ & $\operatorname{Esp}$ & $\div \because 00$ & pRok & WTERSEC & o. & $\{\mathrm{mg} / \mathrm{i}\}$ \\
\hline 1246 & 778 & Alegr & Caicó & 722,7 & $9.293,2$ & $\infty$ & $8 / 83$ & 51,60 & $8,50 \mid$ & 25,00 & 1.241 & 75 & se & Areia & 1,0 & $\overline{\text { S.fra }}$ & $5,6-9$ & $12-15-39,6$ & Elev. & $4.239,6$ \\
\hline & 779 & Riacho das & & - & 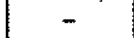 & $10 c$ & & 54,50 & 3,58 & 29 & & 345 & & & & & & & $x_{1}$ & 940,0 \\
\hline$S$ & 848 & Varzea Comp & " & - & - & loc & $11 / 83$ & 60,00 & 12,00 & 17,10 & 3.000 & 588 & & Are & 1,8 & - & 7,5 & 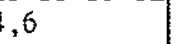 & - & $6.660,4$ \\
\hline & 851 & Caiçara do $\mathrm{C}$ & $"$ & $728,2 \mid$ & $9.280,3$ & loc & $11 / 85$ & $60,00 \mid$ & 4,00 & - & 270 & - & to & | & 1,8 & - & & & - & - \\
\hline & 354 & São Bernardo & $"$ & $722,2 \mid$ & $9.284,6$ & $10 c$ & [II/85 & & 31.00 & 37.00 & 1.285 & 214 & & $" 1$ & 10,8 & Lg.id. & $7,4<I$ & -60 & Talv. & $2.100,0$ \\
\hline d. & 857 & Carai & $"$ & 717,3 & $9.290,1$ & 100 & $11 / 83$ & 60,00 & 3,50 & 11,58 & 3.600 & 445 & & Arg.ar. & 2,0 & Tr.Tr. & 4,5 & & & 65,8 \\
\hline 2 & 857 & molu & $"$ & 716,6 & $9.292,8$ & oc & iij & 58,00 & 9.00 & {$[19,41]$} & 3.000 & 288 & $\mathrm{Ni}$ & $\operatorname{Arg}$ & 10,7 & & 3 & & $"$ & $8.319,0$ \\
\hline 0 & 887 & de Cima & " & 716,3 & $9.302,9$ & oc & $12 / 83$ & $60,00 \mid$ & 3,00 & $11,7\}$ & 3.600 & 413 & & Ar. & 4,1 & r.Tr. & 9, & & is & 436,4 \\
\hline & 891 & More & $"$ & 707,8 & $9,272,6$ & $10 c$ & $2 / 8.5$ & 40,00 & 7,00 & 16,94 & 4) 3.600 & 362 & & & 1,4 & g.Tr. & & & " & 920,5 \\
\hline & 893 & Serr & $\because$ & 4.6 & & 1oc & & & 20,10 & & 3.000 & 721 & Gna & Arei & $i, 2$ & $\operatorname{Tr} . \mathrm{Tr}$ & 20 & , & $"$ & $2.466,0$ \\
\hline & 894 & Cabo & " & 15,2 & 9 & oc & 32 & $60,00 \mid$ & 6,00 & $\mid 11,26$ & 10.285 & 1.955 & & $A r g$ & 3,7 & N.car & 15 & & $"$ & 3,8 \\
\hline & 1.011 & Cast & " & 09.5 & 4,5 & loc & 05 & 60,00 & 3,00 & 32.46 & 1 & 351 & $"$ & Are & 5,9 & & 7, & & Vert. & 690,0 \\
\hline 8 & 1.012 & Boa & $"$ & 9,4 & 9 & oc & $05 / 84$ & $60,00 \mid$ & 2,10 & 40,21 & 782 & 21 & 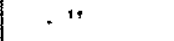 & & 0,9 & fra. & 5, & $8-44$ & Elev. & $1.664,6$ \\
\hline & & & " &, 5 & 6,3 & loc & & $600,00\}$ & 10,50 & 23,81 & 3.000 & 225 & $"$ & Arg & 1,1 & car. & & & Talv. & $1.208,8$ \\
\hline & 1.022 & Sitio Oiti & $"$ & 88,8 & & $\int_{\infty}$ & 0 & 60 & 6,50 & 35,77 & 947 & 52 & $G r$ & $" 0$ & 5,3 & N.car. & 6,3 & & $"$ & 470,4 \\
\hline & 60 & Unari & is & 8 & 9.2 & ac & b & 60,70 & 5,90 & 9,8 & 5.000 & .018 & sto & Ar.arg. & 4,9 & $\operatorname{Tr} . \operatorname{Tr}$. & $11,2-2$ & 2 & $"$ & 8,0 \\
\hline & 1.097 & Barra de Est & $+\cdots$ & 720,9 & $9.277,4$ & $10 c$ & 68 & 58,00 & 1,50 & $|22,86|$ & 2.250 & 10.5 & & & 5,0 & car. & 8, & & $: 4$ & $1.270,4$ \\
\hline 5 & 1.104 & Mulu & $"$ & 02,6 & & 10c & & 45,00 & 2,00 & 23,35 & 8.000 & 705 & & & 3,9 & $r . T r$. & $6-1$ & $4-16,4-32,1$ & :" & $1.326,8$ \\
\hline & 120 & Ales & $"$ & 1 & & Oc & & $60,00 \mid$ & 1,50 & 30,60 & 20 & 25 & & & 1,0 & . $\mathrm{Ci}$. & $2+$ & & . & 7,4 \\
\hline & 36 & Esp & $"$ & 2,4 & 5 & $10 c$ & bs & 60,00 & 1,50 & 26 & 3.384 & 56 & & Argita & 1,9 & . Fra. & & 5,2 & Vert. & $2.769,0$ \\
\hline 6 & 1.175 & iloni & $"$ & 723,3 & 9.3 & $\infty$ & 12 & $60,00)$ & 5,00 & 11,30 & 4.500 & 714 & Gin & Ar.arg. & 4,0 & g.Id. & 30 & 4,2 & TaIv. & $3.939,6$ \\
\hline & 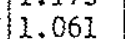 & Xic & $2 \mathrm{~m}$ & $\$ 771,0$ & 4.4 & IOc & & 60 & $+0,40$ & $13,46 \mid$ & 3.789 & 273 & ito & 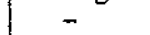 & - & $r . T 5$. & 2. & 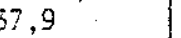 & & 6,0 \\
\hline 8 & 1.224 & Cari & & 772,9 & 5,0 & $\alpha$ & 6 & $60,60 \mid$ & 5,00 & 22,92 & 2.200 & 67 & & Areia & 3,0 & S.IInt & 11 & $33-$ & Elev. & \\
\hline 69 & 1.063 & irding & Cruzeta & 739,6 & 9. & $10 c$ & 07 & 60,60 & 9,80 & 13,41 & 4.000 & 1.108 & sto & Ar.arg. & 1,0 & Ir.Tr. & 7 , & & Talv. & 741.8 \\
\hline & 1.219 & Pau & & 742,1 & & oc & & 60 & & - & 00 & - & & & 3,0 & & & & Vert & \\
\hline 1 & 993 & Tama & larrais & 772,0 & 9. & oc & 04 & 50,00 & 4,50 & 20,82 & 20.0 & 368 & ito & $" 1$ & 0.8 & & $6-$ & -26 & & 5,8 \\
\hline & $=$ & Lago & Nit & 67,2 & & oc & & 60,00 & 5,70 & 20 & 0.0 & 627 & sto & $" 1$ & 2,5 & $r$. & & & Elev. & 8 \\
\hline & $=$ & Faz. & $"$ & 764,4 & 2 & OC & $b$ & $40 ., 00$ & 2,50 & 7,00 & 012.000 & 2.609 & & Arg.ar. & 1,0 & Tr.Tr. & 10 & 2,8 & Talv. & 5,4 \\
\hline 4 & 1.181 & Mora & " & 782,1 & 9 & Oc & 12 & $60,00 \mid$ & 8,50 & 29,40 & 1.800 & 86 & & $\operatorname{Ar}$. & 2,4 & $\mathrm{Ci}$ & & $x$ & & .8 \\
\hline & & & " & 0.1 & & oc & & & 3,00 & & 012 & 73 & G & & 15 & a. & & & Elev. & .0 \\
\hline & 84 & Cat & " & 787.2 & & 100 & 12 & 30 & 6,50 & 24 & 1. & 91 & $\mathrm{Mi}$ & Arei & 4, & ii & & & Talv. & 2,0 \\
\hline & 1.185 & aré II & in & 771,7 & 9. & 10c & 12 & 60,00 & 2,50 & 13,09 & 2.8 & 263 & to & & 1 & & & & & 0 \\
\hline & Nat & Tra & " & 768,2 & & loc & & 52,00 & 9,50 & 11,23 & 33.000 & .734 & & Ar. & 1,8 & $r$. & 13 & & Ver & 875,0 \\
\hline & 25 & Jas & Equado & 4,8 & $\overline{3}$ & $10 c$ & 02 & 60 & 0 & - & I & 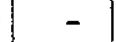 & Quartzito & Al:aren. & 3,0 & & & & Elev. & \\
\hline 0 & 673 & Sede & " & 752,2 & 8 & $O c$ & 12 & $|60,60|$ & 3,70 & 30,35 & $1.44 \mathrm{U}^{\circ}$ & 54 & Micaxisto & Ar.arg. & 5,0 & & & & & 2 \\
\hline & 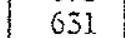 & $\cos$ & $\operatorname{lom}$ & $|742,2|$ & & $\alpha$ & & & 1,20 & & 5 & 25 & se & Al.are. & 20,5 & $\mathrm{Lg} \cdot \mathrm{Ci}$ & & & 221 &, 3 \\
\hline & 632 & Ip & 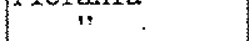 & 740.9 & 9. & oc & 67 & 301 & 0,65 & 30. & 31.6 & 58 & & "ar.a & 89,6 & $\mathrm{Ag}$ & & & & 5,0 \\
\hline & 81 & Pat & "1 & 4 & & $\alpha$ & & 60 & 1,90 & & & 59 & $"$ & Aro & 10, & & & 9. & $"$ &, 0 \\
\hline & & lat & Ips & 8 & & Oc & & & 8.09 & $33,(x)$ & 2.800 & 10 & $"$ & & 1 , & & 12 & $6-10,5$ & " &, 6 \\
\hline & 570 & San & & 745,4 & & $\alpha$ & 62 & 60.00 & 2,92 & 44,90 & 0 & 1 & $"$ & Arei & 2,0 & $A g$ & & & $"$ & $3.302,5$ \\
\hline & 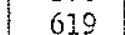 & $L=8$ & . & & & 10 & & 181 & 7,80 & 10 & 53.272 & 0 & $"$ & & 6 & & & & & - \\
\hline & 977 & $\mathrm{Ca}$ & Tpue & 693.4 & & $10 c$ & & & 2.50 & & 4.5 & 20 & , & in & & & & & & 0 \\
\hline & 079 & Wolt & . & .5 & & $10 \mathrm{c}$ & 0 & & $2 i$, & & & 4 & 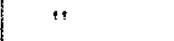 & & 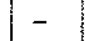 & S.rra & & $.1-52$ & Vert. & \\
\hline & & Bon & 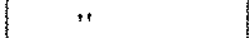 & 109 & & $\infty$ & & & $\mid 0.50]$ & & d & 2 & $"$ & & 2, & & & & & \\
\hline & & Gurr & & 752.6 & & 60 & & & 1,50 & & 7.2 & 736 & Nicax & hr. & 2,5 & Tr.Tr. & & & 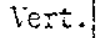 & 9,0 \\
\hline$x$ & & Goci & & 727,6 & & $10 c$ & 64 & & 2,40 & 19,59 & 2.6 & 15 & & Ars & 8,6 & $A g$ & 11 & & & \\
\hline & & $15 i$ & I & & & ec & & & 1,00 & 14.35 & 53.6019 & 20 & $"$ & Ars & 3,8 & ind & 9 & & & $2,772,8$ \\
\hline & & & & & & & & & 1.60 & $2 i$ & 27.2 & 246 & " & & - & 2 & & & & 1.0 \\
\hline & & & & & & 6 & & & 2.60 & & & & & & & & & & & \\
\hline
\end{tabular}


CADASTRO GERAL DOS POÇOS PERFURADOS NOS ESTADOS DO RIO GRANDE DONORTE E PARAIBA

\begin{tabular}{|c|c|c|c|c|c|c|c|c|c|c|c|c|c|c|c|c|c|c|c|}
\hline & & DADOS & $C A C 1 O N$ & A $1 \mathrm{~S}$ & & & DATA & DADOS & $S T E$ & CNICO & DS 00 & POÇO & DADOS & os, & FIS & OG & FICOS & f & os \\
\hline No & NOCAD. & $10094=00=$ & punuscón & COORD. & GEOGRAF & 19 & & & & & & $\overrightarrow{A Z \overrightarrow{A O}}$ & & MANTO COE & BERT: & & FRATURAS & & \\
\hline & PERFUR & LUCALIOAUE & MUNTETPOO & tons & LATIT. & \begin{tabular}{|l}
$\overline{0}$ \\
$\dot{u}$ \\
$\alpha$
\end{tabular} & POÇO & FUNO. & (m) & & & $\begin{array}{c}c \\
\mathrm{c} n\end{array}$ & A A & $N A \div E \operatorname{ESTA}$ & $\operatorname{ssp}$ & $\because 100$ & D4OF :NTE & HIO & $\{\mathrm{mg} / 1\}$ \\
\hline & 1.215 & Carnaubinha & Ouro Branco & 735,2 & 259,2 & oc & $02 / 85$ & 60,00 & 7,005 & 33,36 & 409 & 16 & Mic & Areia & 0,8 & S.Era. & $11,6-17,3-26-52$ & Elev. & 684.0 \\
\hline & 981 & acho da Mads & Parau & 705.2 & 6,1 & $0 c$ & $03 / 84$ & 57.00 & 3.701 & & 6.545 & 498 & Gra & Ar. & 1,4 & S. fra. & $5-16-19-22-41-56$ & & 99,2 \\
\hline & 407 & Varante & Parelhas & 770,5 & $9.259,0$ & $\mid$ & $06 / 82$ & 52,00 & 4,000 & 32,09 & 2.400 & 80 & $\mathrm{MiC}$ & & 1,3 & & $18-24-34$ & н & 4,0 \\
\hline & 598 & Riacho do Boi & & 772,9 & $0.261,6$ & $\infty$ & $\mid 03 / 82$ & 48,50 & 5,001 & 10,51 & 9.000 & 1.695 & Quar & Are & (1,0 & Tr.Tr. & $-10-12$ & TaIv. & 0,0 \\
\hline & 599 & Olho d'Agua do & 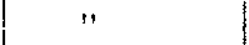 & 1,9 & & $6 c$ & $05 / 82$ & & 2,001 & & & 408 & Mic & & 1,0 & & & & 769,2 \\
\hline & 600 & Salgadinho & . & 771,6 & 3,6 & $a$ & $05 / 82$ & 45,00 & 6,569 & 13,77 & 2.181 & 292 & $f^{3}$ & Arr & 5.0 & $\mathrm{Tr} . \mathrm{Tr}$. & ii, & Talv. & 302,8 \\
\hline & 680 & Sarito Antor & 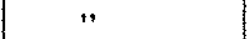 & 7,8 & 9.8 & $|0 c|$ & $01 / 85$ & 36,70 & 3,361 & 34 & 2.057 & 163 & $"$ & en. & 3,6 & $\mathrm{Ag} . \mathrm{Tr}$ & 20 & Vert. & $1.307,2$ \\
\hline & 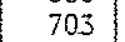 & Reti & " & 2 & & $\mid \begin{array}{l}0 \\
0\end{array}$ & $03 / 83$ & & 1,00 & & & 2.045 & $"$ & & 7,8 & & $8,8-5$ & & 994,4 \\
\hline & 727 & Volta do Rio & $\therefore$ & 1,7 & 4,4 & $0<$ & $0.6 / 83$ & 36,00 & 3,60 & 18,87 & 24.000 & 1.561 & $"$ & Are & 3,6 & $\operatorname{Tr} . \operatorname{Tr}$. & $8,7-1 I, I$ & Taly & 574,6 \\
\hline & 728 & Sobr & ( & & & oc & $06 / 83$ & & 6,500 & & & 804 & $"$ & & & Tr.Tr. & 11,2 & 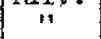 & - \\
\hline & 733 & Cachoeira I & " & 758,9 & .6 & $\left|\begin{array}{l}n \\
0<\end{array}\right|$ & $07 / 83$ & 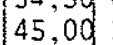 & 2,382 & 26,64 & 1.000 & 4 & Grai & & $\begin{array}{l}1,0 \\
1,0 .\end{array}$ & $\mathrm{Ag} . \mathrm{CI}$ & $22,1-41,3$ & " & \\
\hline & 841 & Sede & $"$ & & & $\infty$ & $10 / 83$ & & 12,262 & & 18.000 & 1.310 & Qua & & 2,3 & N.car. & $11-13$ & lev. & 335,4 \\
\hline & 5 & 1 & " & & & $|0 c|$ & $\mid 31 / 83$ & & 11,72 & & & 247 & & & 0,9 & & $3-9-14-21$ & $"$ & 777,0 \\
\hline & 864 & Sobradinho II & $"$ & 9 & 3,0 & oc & $11 / 83$ & & 4,55 & 15,30 & 2.570 & 239 & sto & $\mathrm{Ar}$ & 7,3 & Lg.id. & $9,6-13,9-$ & alv & 860,0 \\
\hline & 870 & Cach & $"$ & & & 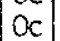 & $\mid 11 / 83$ & & 11,5003 & & 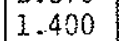 & 76 & Gra & & 1,1 & $\mathrm{Ag} \cdot \mathrm{Ci}$ & $6-1$ & & 494,2 \\
\hline & 879 & Sede & $"$ & & & $0 c$ & $12 / 83$ & & 16,402 & & 1.600 & 242 & Qua & AI. & 2,2 & Tr.Tr. & $-19-2$ & vert. & 777.4 \\
\hline & 892 & Sede VI & " & & & Oc & $12 / 83$ & & 0,8 & & 20 & 547 & & renl & 5,8 & N.car. & $-11-1$ & Elev. & 061,0 \\
\hline & 970 & Olho & $"$ & & & $\mathrm{Cc}$ & $03 / 84$ & & & & 1 & 83 & Nica & & $\mid \begin{array}{l}2,0 \\
1,5\end{array}$ & Lg.Ci. & $5,3-7,4$ & Talv. & $888 ; 4$ \\
\hline & 971 & Malnada Verme & $\because$ & 762,3 & 5 & $\alpha$ & $03 / 84$ & di & 9,505 & 58,86 & 546 & 18 & mas & & & S.fra. & $0,1-10 ; 7-19,2$ & Elev. & 3.6 \\
\hline & 973 & Prea & $"$ & & & oc & $|03 / 84|$ & & 4,705 & 54 & 3.600 & 121 & $" 1$ & $" *$ & 12 & $a$ & 19 & $\cdots$ & \\
\hline & 1.195 & Bokn & $"$ & & & oc & 01 & & 4,7 & & 42 & 48 & "1 & , & 1,5 & S.fra & $10,5-$ & $"$ & .8 \\
\hline & 1.200 & Monte II & $"$ & 2 & 0.2 & $0 c$ & $01 / 85$ & & 4,201 & 19,57 & 5.142 & 354 & $n$ & 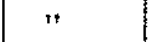 & & S.fra. & 6 & Vert & 4 \\
\hline & 11 & dos $\mathrm{Ne}$ & " & 8 & 2 & $\infty$ & $01 / 85$ & 6 & 3,004 & 10 & 2 & 340. & $"$ & en. & 4,0 & Lg.id. & & alv. &, 2 \\
\hline & 14 & Suss & "t & 7 & 7 & act & 01 & & 3,5015 & 8 & 500 & 14 & Gna & & 1,7 & Ag.Ci. & $11-19,4-35,8-46$ & Vert. & 8 \\
\hline & 1.265 & Cinz & "! & 771,9 & $9.251,8$ & $0 c$ & $07 / 85$ & & 1,455 & 5 & 1.107 & 39 & Mic & & & S.fra. & $8_{-}^{1+}$ & Elev. & $1.189,6$ \\
\hline & 73 & Noty & $"$ & 76 & 8 & $10 c$ & $0.8 / 85$ & 6 & 1,701 & 16,35 & 2.065 & 142 & & & 4,0 & $\mathrm{Ag} . \mathrm{Ci}$ &, 4 & Talv. & - \\
\hline & 75 & Jara & $"$ & & 9.2 & $a c$ & $08 / 85$ & & - & Non & 200 & & & & 4,0 & S.fra. & 18 & 12 & - \\
\hline & 78 & Riacho to Boi & $"$ & & & $0<$ & 108 & & 0.50 & 5,70 & 9.000 & 731 & Qu: & - & $\ldots$ & Tr.Tr. & 3 & $"$ & - \\
\hline & $\begin{array}{l}1.276 \\
1.279\end{array}$ & $\begin{array}{l}\text { Klacho GO BOD } \\
\text { Tapera }\end{array}$ & $"$ & 77 & 2 & $0<$ & 108 & 61 & 15,004 & 42, & 2.000 & 74 & Mica & Ar. & 3,9 & $\mathrm{Ag} \cdot \mathrm{CJ}$ & $10,6-21,2-$ & " & $7 \rightarrow$ \\
\hline & 695 & S.Jo & Pedro Avel & 1) & 2,1 & Oc & 03783 & & 2,3 & 5,52 & 3.600 & 1.055 & Onaj & & & & & , & 187,2 \\
\hline & 836 & tevāo & & & & $0 c$ & 10 & & 16, & 15,64 & $=$ & 8.034 & & & $\tilde{\sigma}$ & Tr.Tr. & 13 & " & \\
\hline & 840 & Sede & 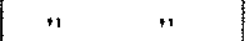 & & 0 & $0 c$ & 10 & & 2,50 & & 8 & 1.069 & & & 1,4 & Lg.Tr. & -23 & Vert. & 0 \\
\hline & 909 & Sto.F & * & & & $0<$ & 01 & & 3,50 & 5 & 4. & 2.143 & , & " & & Tr.Tr. & 5 & TaI & 4 \\
\hline & 677 & $S$ & antana S & 75 & & $\infty$ & $01 / 83$ & 6 & 2,202 & & 10 & 86 & $\mathrm{MiC}$ & & 5,0 & S. & $8,-12,9$ & Vert. & .5 \\
\hline & 532 & $\mathrm{~F}$ & - J.do Sabi & & & $a$ & 02 & & 5 & 0 & 1 & 42 & & & & & & Ta1v. &, 2 \\
\hline & - & & 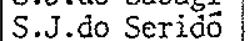 & & & oc & 10 & & 6,7 & & & 19 & $\mathrm{M}$ & & 4, & $r$. & 6. & Ve &, 0 \\
\hline & 1.076 & mua & & & & $\infty$ & 08 & 6 & I. & & 1.59 & 53 & {$\left[x^{2}-2\right)+3$} & & 2 , & & 5 & Talv. & .0 \\
\hline & 820 & $T$ & $" * n$ & 0 & 2 & oc & $10 / 83$ & 4 & 2,4 & 4 & 24.000 & 1.943 & Micaxisto & At. & 2,6 & $x$ & 6, & lert. & \\
\hline & 000 & a & São Vicente & & & Oc & & & & & & $44]$ & & & & & & & 4 \\
\hline & 806 & io & S.Negra Nort & & & 0 & 109 & 6 & 2,8 & & 3.789 & 560 & Gna & Are & 4,4 & $\mathrm{Lg}$. ind & $.2-14$ & Els & 4 \\
\hline & 810 & Saco de Feijāo & & 3 & & $0 c$ & 109 & & 4.6 & & $2 x$ & 15 & & Ar. & 7,7 & S.1 & & TaIv. & \\
\hline & 20 & II & $\because$ & & & oc & & & 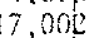 & & 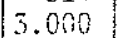 & 284 & & & 1.0 & & 6 & Nez &, 2 \\
\hline & r & $60 \mathrm{I}$ & $n$ & & & $|\alpha|$ & 02 & 4 & 8,0 & 84 & 1.800 & 112 & $\tilde{e}$ & Are & 1.5 & S.fra. & $1 i$ & Bis &, 2 \\
\hline & 948 & 20 II & 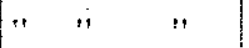 & 9 & $9 . \hat{2}$ & 0 & $02 / 84$ & & $4,00^{1}$ & & & 763 & & & 1,8 & ir.ix. & 7,2 & Talv. & \\
\hline & 952 & Solidão III & $"$ & & & $0 c$ & 02 & & 4,50 & & & 758 & & $"$ & $\left|\begin{array}{l}2,0 \\
7,0\end{array}\right|$ & $x$. & $17-21-28,1$ & jert. & \\
\hline & $1.10 \%$ & & " & & & $\infty$ & & 32 & & & 3.600 & 235 & & & 4.01 & IS.Tr. & 7.7 & Taly. & 352.0 \\
\hline & 1.250 & Sandade & " & 688.0 & 3.3 & oc & $07 / 85$ & 60 & 0.005 & & 500 & 13 & 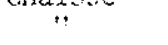 & & 4.5 & - & $-26-45$ & - & 8 \\
\hline 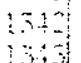 & $1.1+1$ & Arcia de Raim & $\begin{array}{l}\text { Ague Nova } \\
\text { Mexandria }\end{array}$ & $\begin{array}{r}6 \\
4 \\
4\end{array}$ & 9.5 & $\frac{\alpha}{\alpha c}$ & $\begin{array}{l}10 / 84 \\
07 / 85\end{array}$ & 48,60 & 2,270 & & $\begin{array}{l}3.272 \\
3.000\end{array}$ & $\begin{array}{l}307 \\
231\end{array}$ & "i" & $\because:$ & 1 , & 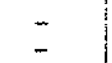 & $\begin{array}{l}6-30-13=2 \pi \\
4.8-26-28-5\end{array}$ & 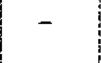 & $\begin{array}{l}574.0 \\
149.2\end{array}$ \\
\hline
\end{tabular}


CADASTRO GERAL DOS POÇOS PERFURADOS NOS ESTADOS DO RIO GRANDE DONORTE E PARAIBA

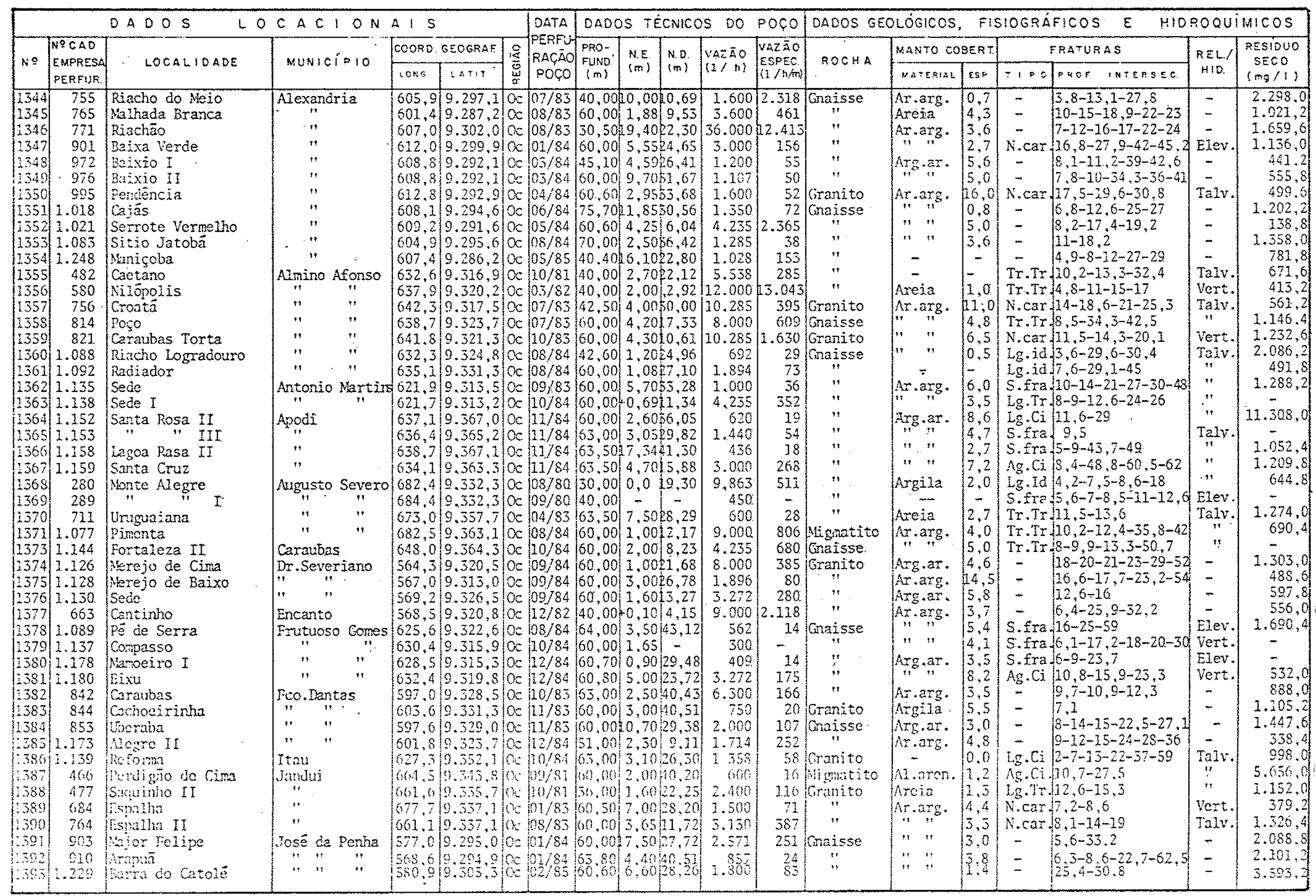


CADASTRO GERAL DOS POÇOS PERFURADOS NOS ESTADOS DO RIO GRANDE DONORTE E PARAIBA

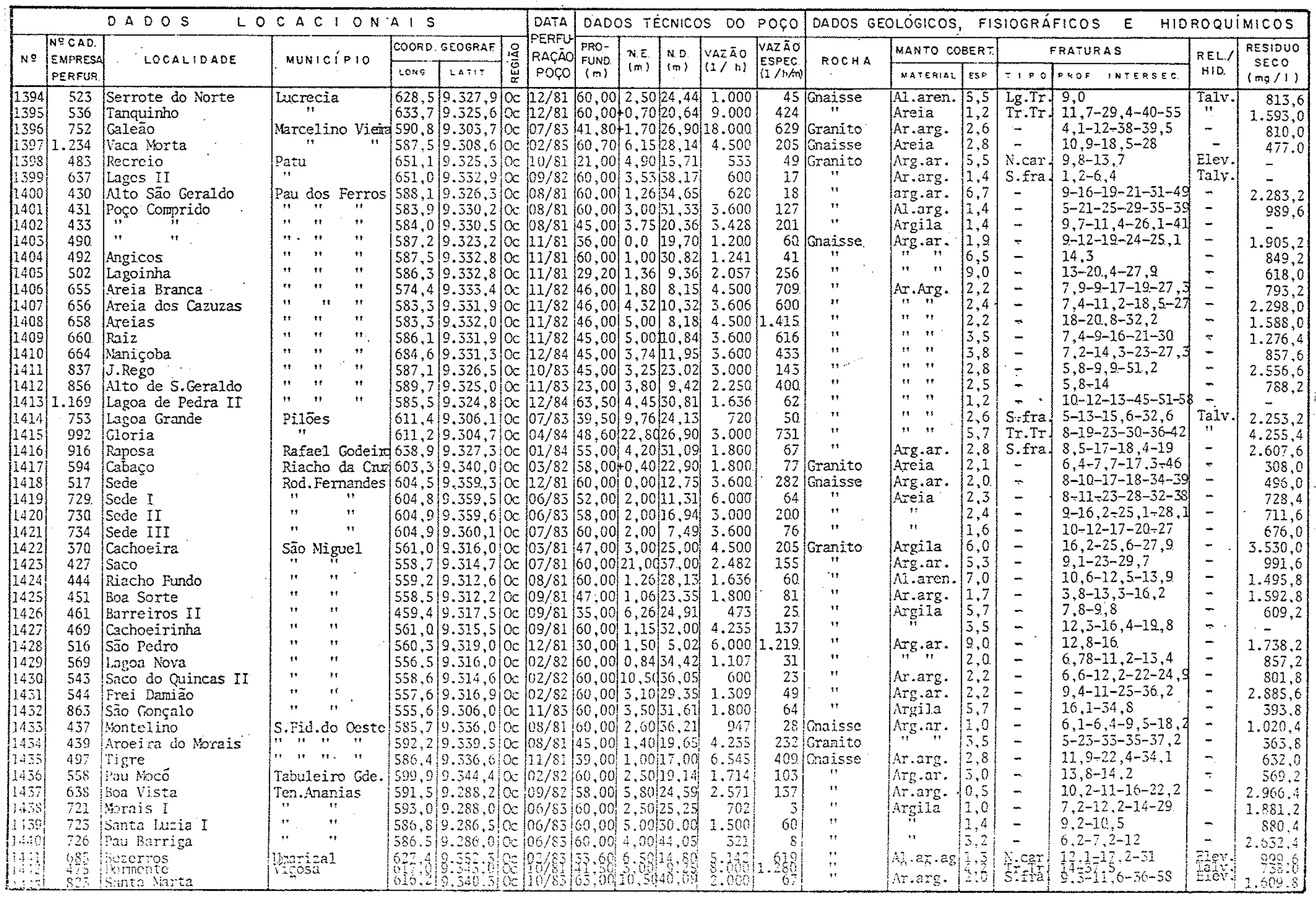


CADASTRO GERAL DOS POCOS PERFURADOS NOS ESTADOS DO RIO GRANDE DONORTE E PARAIBA

\begin{tabular}{|c|c|c|c|c|c|c|c|c|c|c|c|c|c|c|c|c|c|c|c|c|c|}
\hline \multirow{3}{*}{ NNO } & \multirow{3}{*}{$\mid \begin{array}{l}N O C A D \\
\text { EMPRESA } \\
\text { PERFUR }\end{array}$} & \multirow{3}{*}{$\begin{array}{l}A D O S \\
\text { LOCALIDADE }\end{array}$} & \multirow{3}{*}{\multicolumn{2}{|c|}{$\frac{C A C I O}{\text { MUNICIPIO }}$}} & \multirow{2}{*}{\multicolumn{2}{|c|}{$\begin{array}{l}\text { A I S } \\
\text { COORD GEOGRAF }\end{array}$}} & \multirow{3}{*}{ 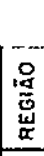 } & \multirow{3}{*}{$\begin{array}{l}\text { DATA } \\
\text { PERFU } \\
\text { RAÇAOO } \\
\text { POÇO }\end{array}$} & \multicolumn{5}{|c|}{ DADOS TEECNICOS DO POCO } & \multicolumn{8}{|c|}{ DADOS GEOLÓGICOS, FISIOGRÁFICOS E HIOROQUIMICOS } \\
\hline & & & & & & & & & \multirow{2}{*}{$\begin{array}{c}\text { PRO- } \\
\text { FUND } \\
(\mathrm{m})\end{array}$} & \multirow{2}{*}{$\begin{array}{l}N E \\
(m)\end{array}$} & \multirow{2}{*}{ N. 0} & VAZÃO & VAZÄO & & MANTO COE & BERT: & & FRATURA & As & $\dot{E} \mathrm{E}$. & $\begin{array}{l}\text { IESIOUO } \\
\text { SECO }\end{array}$ \\
\hline & & & & & LOMG. & LATHT & & & & & & $(3 / n)$ & & ( & NATERIAL & Eso & $1 \cdot 0$ & PnoF 1 & IATERSEC & & \\
\hline & 07 & Ribeirāo de Baixo II & Alagoa $\mathrm{Gr}$ & rande & - & - & Or & 181 & 22,00 & 3,15 &, 75 & 37 & 160 & & & 10,0 & & 13 & & 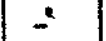 & 491,3 \\
\hline & & Pé de & $"$ & $"$. & & 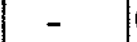 & & & & & & 8. & 845 & & & 9.0 & - & & & & 7,7 \\
\hline & PF-09 & Espalh & $"$ & $"$ & - & - -: & or & $09 / 81$ & 22,00 & 2,00 & 12,04 & 630 & 63 & $"$ & Arg.ar. & 4,0 & - & 13, & & - & $2.023,6$ \\
\hline & $R P$ & Ribeir & Alagoinha & a: & - & - & or & & & 1,92 & & 2.800 & 432 & $"$ & Silt.arg & 9,0 & - & & & & 6,0 \\
\hline & & Siti & $"$ & & & & or & & & 6,03 & 22,95 & 1.321 & 78 & Granito & 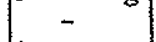 & 10,0 & - & 31,7 & & & $5.760,0$ \\
\hline & $|1 P P W-82|$ & Sap & Bananeira & & - & - & or & $12 / 82$ & 50,00 & 5,50 & 16,92 & 819 & 72 & $"$ ". & Arg.ar. & 4,8 & - & & & & 7,7 \\
\hline & WF & foiticica & " & & - & - & Or & $02 / 84$ & & 4,22 & & 2.561 & 609 & $"$ & $\arg \cdot$ & 6,0 & - & $?$ & & & 32,0 \\
\hline & RPA-72 & Cupira & Barra Sta & a. Rosa & 818,7 & 5,9 & Or & $05 / 82$ & 45,00 & $5,80)$ & 16,79 & 1.241 & 112 & Gnaisse & Arg.ar. & 3,0 & $\operatorname{Lg} . \mathrm{Tr}$. & 26,2 & & Talv. & $\begin{array}{l}6.240,0 \\
2.623,0\end{array}$ \\
\hline & RPA-145 & Sitio Inveja & Barra 5.1 & Miguel & 799,8 & & Or & 83 & & $\mid \begin{array}{l}6,97 \\
3,22\end{array}$ & & $\begin{array}{l}4.010 \\
2.647\end{array}$ & $\begin{array}{l}261 \\
500\end{array}$ & $"$ & $\begin{array}{ll}\mathrm{rg} \cdot \\
\mathrm{ar} .\end{array}$ & $\mid \begin{array}{l}1,0 \\
3,0\end{array}$ & - & $\begin{array}{l}36,9 \\
8\end{array}$ & & 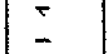 & $\begin{array}{l}2.025,0 \\
6.371,0\end{array}$ \\
\hline & & $\begin{array}{l}\text { Tanque Rosa } \\
\text { Mulungu }\end{array}$ & $"=$ & $"$ & {$\left[\begin{array}{l}814,4 \\
790,0\end{array}\right]$} & 9 & or & 81 & 00 & {$\left[\begin{array}{l}3,22 \\
2,20\end{array}\right]$} & $\begin{array}{r}8,51 \\
21,98\end{array}$ & $\begin{array}{r}2.047 \\
334\end{array}$ & $\begin{array}{r}540 \\
16\end{array}$ & $"$ & rg. & 0,5 & - & & & - & $1.135,4$ \\
\hline & RPt-71 & Olho D'Agua & Boqueirāo & & 815,6 & & or & & & & & 2.571 & 137 & $"$ & g. & 3,0 & - & 30,5 & & & $10,444,0$ \\
\hline & WBB-96 & Volta do Alcantil & 11 & & 829,0 & 5 & or & $06 / 85$ & & 1,56 & 15 , & 4.417 & 310 & "1 & Are & 3,0 & - & 21,7 & & - & 75,0 \\
\hline & $\mid \mathrm{WBO}-182$ & Lagoa Danta & Banane & & & & for & & & $7,90)$ & 21,30 & 3.272 & 244 & $"$ & ar. & 3,0 & - & 6 & & - & 827,0 \\
\hline & & Mal & Cabaceira & & 787,1 & & for & 2 & & 3,64 & & 2. & 435 & $"$ & ar: & 3,0 & - & & & 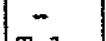 & 890 \\
\hline & & $\mathrm{Rib}$ & $"$ & & 791,5 & & for & & & 2,70 & & 5. & 40 & $"$ & & 3,0 & - & & & ialve & 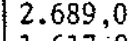 \\
\hline & & eca & $"$ & & 5,3 & & Or & & & II & & & 29 & $" 1$ & & 1,0 & - & & & & $7 ; 0$ \\
\hline & $A Q-221$ & Tat & $"$ & & 3 & & Or & $08 / 84$ & 0 & 5,25 & & 11.076 & 2.653 & $"$ & Sil & 2,0 & & & & & \\
\hline & $-97\}$ & $\mathrm{Pa}$ & " & & & & Or & & & & & 3. & 16. & $"$ & it. & 3,0 & & & & & 50,0 \\
\hline & 98 & $I T$ & $"$ & & & & Or & & & & & & 7 & 11 & AxE & 3,0 & & & & & 7. \\
\hline & $\mathrm{AQ}$ & Volta & $"$ & & 3 & & or & & & 30 & & 2. & 31 & $"$ & $1 t$ & 1,0 & & & & $"$ & \\
\hline & & nelho & $"$ & & & & $10 \mathrm{~T}$ & & & & & 5. & 61 & $"$ & $A r . s$ & 3 & & & & 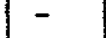 & 0 \\
\hline & & $\mathrm{Cac}$ & $"$ & & & & for & & & & & 2.8 & 209 & $"$ & - & 0,0 & & & & & \\
\hline & RPA-55 & Roça Nova & Camalau & & & & Or & & & & & 3. & 906 & & Ar & 2 , & & & & - & 0. \\
\hline & RPA-120 & Sede & $"$ & & & & Or & & & & & 2. & 94 & & & 3. & & & & - & 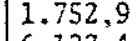 \\
\hline & & rão & $"$ & & 8 & & for & & & & & & 37 & & Ar & 2 & & & & & \\
\hline & & & $"$ & & & & for & & & & & & 110 & & Ars & 0 & & & & ( & 2,0 \\
\hline & & do 1 & $"$ & & & & Or & & & 3. & & 7. & 565 & & Aren.arg. & 3,0 & & & & - & 8. \\
\hline & & $10 i$ & $"$ & & 2 & & Or & & & 2, & & 12. & 2.575 & & Areia & I & & & & - & \\
\hline & & da Caiçara & Campis & & - & - & or & 10 & 10 & 2,87 & 11 & 4 & 37 & & Arg.ar. & 0, & & 29,5 & & - & $10.707,0$ \\
\hline & & Ami & & & & - & Or & b & 0) & 6 & & 1. & 44 & & Mr. & 10,3 & & & & - & \\
\hline & $\mathrm{AQ}$ & Candesa & $"$ & & - & - & or & & & & & & 184 & & ilt & 3 & 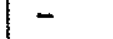 & & & - & 4.4 \\
\hline & -22 & Boa Vista & $"$ & $" 1$ & 34,2 & & for & $p$ & & & & & 27 & & Ia & I. & & & & 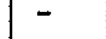 & \\
\hline & & $\mathrm{Fa}$ & $"$ & 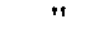 & 804,0 & & or & 1 & 0 & 6 & & 1. & 362 & & arg. & 1 & & & & & \\
\hline & & Gal & $"$ & $" 1$ & 815,0 & & no & {$[15$} & & 9 & & 0 & 110 & & Mreia & II. & - & 22,3 & & - & \\
\hline & & $\mathrm{Fa}$ & $"$ & 11 & & & for & & & & & 1.26 & 28 & Gna & & E & & & & - & \\
\hline & & Cachocira dos P & $\pi$ & " & & & or & & & & & 4 & 16 & & Ar.a & 1 & & & & - & \\
\hline & & Jucuri & $"$ & ." & & & fr & & & & & & 33 & & Argila & 1 & & & & - & \\
\hline & & & "* & $"$ & 829,2 & & for & 12 & & 4 & & 1.506 & 89 & $\mathrm{Mic}$ & - & b. & &, 3 & & & \\
\hline & RPI & pui & 10 & & 825,4 & & br & 54 & & & & 6 & 891 & & At.arg. & 3 & & & & - & \\
\hline & & Mot & $m$ & $"$ & & - & $b_{r}$ & & & & & 5 & 4 & & - & he. & & & & - & \\
\hline & $10-$ & Ciube Campestre & $"$ & & - & - & $b=$ & $64 / 85$ & 10 & 8, & & & & " & hr.a & 5 & & & & - & 40,0 \\
\hline & & Riacho do Algodão & 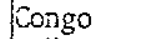 & & & & br & & & 5,80 & & 1.000 & 26 & 4 & & 1 , & - & & & 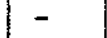 & 4,5 \\
\hline & $R p$ & $"$ " & & & 754. & & $D_{T}$ & & & 4,24 & 12 & 847 & 106 & 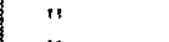 & $"$ & 2,5 & - & 11,5 & & 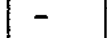 & \\
\hline & & Sitio Bate & & & & & pr & b8 & & 2,83 & & 1.406 & 86 & 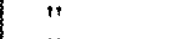 & Al.ar.ag. & 3 & & 20,6 & & - & 0,0 \\
\hline & & Santa $\mathrm{NE}$ & & & 13,3 & 9.27 & br & $0.7 / 85$ & & & & 631 & 2 & "t & Ar.silt. & 3 & 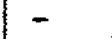 & 29,1 & & $=$ & $4.140,0$ \\
\hline & lephi & Sit & & & & - & or & $11 / 81$ & 50,00 & 7,56 & 13,94 & 847 & 132 & 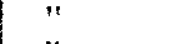 & Ar.arg. & 5,0 & - & & & Talv & $4.755,0$ \\
\hline 153 & WP & "Monsucesso & Esperanca & & & - & & $\begin{array}{l}03 / 84 \\
06 / 82\end{array}$ & & 8,50 & & $\begin{array}{l}597 \\
402\end{array}$ & $\begin{array}{l}27 \\
22\end{array}$ & Migmatit & ar.arg. & 8,0 & - & 9,7 & & $\bar{z}$ & $\begin{array}{l}19535,0 \\
4.591,0\end{array}$ \\
\hline
\end{tabular}


CADASTRO GERAL DOS POÇOS PERFURADOS NOS ESTADOS DO RIO GRANDE DONORTE E PARAIBA

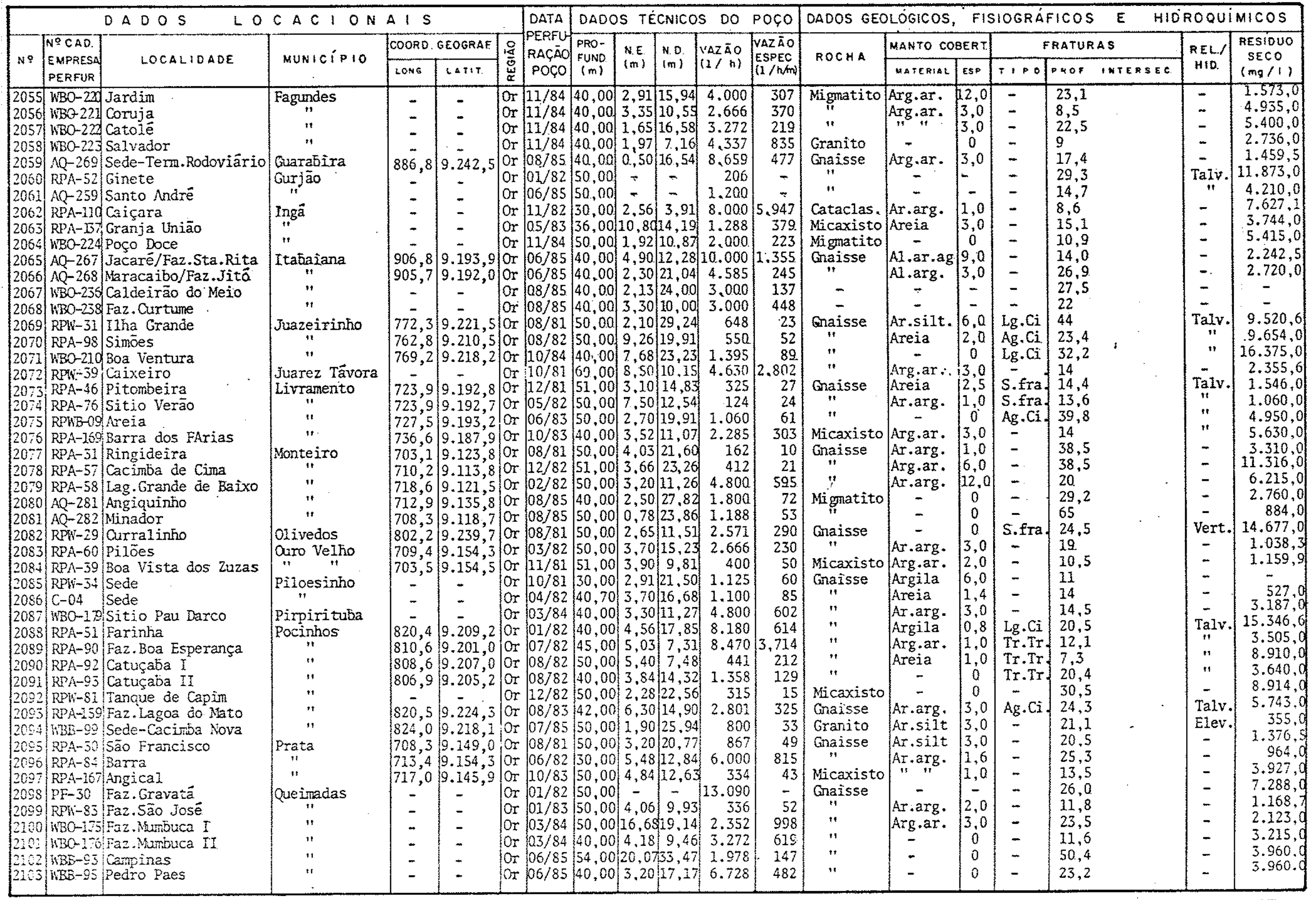


CADASTRO GERAL DOS POCOS PERFURADOS NOS ESTADOS DO RIO GRANDE DO NORTE E PARAIBA

\begin{tabular}{|c|c|c|c|c|c|c|c|c|c|c|c|c|c|c|c|c|c|c|c|c|}
\hline & & $D A D O S$ & $C A C I O N$ & $A \perp S$ & & & DATA & DADO & $D S T E$ & ENICOS & $S$ DO & POÇO & DADOS GEO & DLÓGICOS, & is & S10 GRA & ÁFICOS & HID & OQU1 & M1COS \\
\hline $0^{\circ}+2$ & NOCAD. & & & COORD. & GRAF & 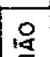 & & & N. & D. & $Z \bar{A} O$ & Traz $\bar{A} O$ & & MANTO COE & BERT: & & FRATURA & AS &.$/$ & EESIOUO \\
\hline 14 & PERFUR. & 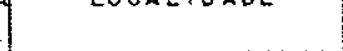 & & LONS & ATIS. & 焉 & POÇO & $(n$ & & & & & & MATERIAL & ESP & 100 & $040 \%$ & INTERSEC. & & (1) \\
\hline T & RPw-33 & Manus & S.Joäo Carixi & 018,0 & & Or & 181 & & 4 & & & 53 & & & 10 & & 1,5 & & & $.830,2$ \\
\hline & -54 & Cacho & $" \| "$ & 774,7 & & or & 82 & & & & & 362 & & & & 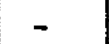 & & & 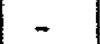 & \\
\hline & RPA-69| & Nalh & " & $772+3$ & & or & $04 / 82$ & & 12 & & 57 & 235 & & m & & $m$ & & & - & \\
\hline & RPti-74 & Forquilha d & $" 1$ & 774,3 &, 5 & or & $03 / 82$ & 5 & 11,78 & 19,97 & 470 & 57 & & $"$ & & - & 3 & & - & $.596,0$ \\
\hline & RPA-97| & Sitio Barreiro & $\because "$ & 775,3 & $9.163,2$ & Or & $08 / 82$ & 42,00 & 5,93 & 10,24 & 3.512 & 814 & & Arg & 1,0 & 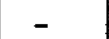 & 3,9 & & 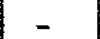 & 47,0 \\
\hline & RPUB-OS & SRiacho dos 0 & ng & 776 & & or & $05 / 83$ & & $6,37 \mid$ & 7,34 & & 231 & & & & 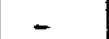 & 17,7 & & 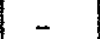 & \\
\hline 0 & $\mathrm{WBO}-172$ & Jưruçu III & in & 774,3 & & $0 x$ & $03 / 84$ & 40,00 & 7,88 & 26,76 & 911 & 48 & & - & . & - & 1, & & - & 75.0 \\
\hline & -82 & Gira & " & 771,6 & 5 & or & $\mid 07 / 84$ & 40,00 & 1,94 & $7,56 \mid$ & 8.181 & 1,455 & & Argila & 1,0 & - & 22,6 & & - & \\
\hline & & deira & " "do Tigre & 767 & & Or & $06 / 83$ & 33,00 & 3,60 & 20,96 & 649 & 39. & & Areia & & - & - & & - & $.937,0$ \\
\hline 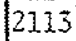 & RPA-24 & Serz & S.José Cordeiro & 733,8 & 5 & Or & $108 / 81$ & 50,00 & 3,52 & 9,18 & 2.769 & 488 & $\therefore$ & Arg.ar. & 3 & 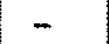 & 14,5 & & Talv. & 93,3 \\
\hline & -63 & Simão Lopes & $" 1 "$ & 746,2 & & or & $03 / 82$ & $48,00 \mid$ & 5,47 & $\mid 13,42$ & 2.250 & 283 & $"$ & & 1 & - & & & & \\
\hline & RPA-85 & Serrota de Cinn II & $1 " n$ & 747,3 & & Or & $06 / 82$ & $|38,00|$ & 3,77 & 9.60 & 7.346 & 1.258 & $"$ & Ar.: & 3,0 & 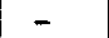 & & & t. & 0 \\
\hline & -155 & Cardoso de B & 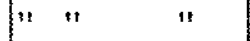 & 747,1 & $9.194,3$ & or & $03 / 83$ & 20,00 & 4,68 & 7,32 & 8.000 & 2.914 & $"$ & 11 & $1,0$. & - & \pm & & & $2.154,0$ \\
\hline & & Siti & " " & 47,2 & 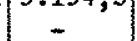 & Or & $07 / 85$ & $40,00 \mid$ & 0,85 & $|20,31|$ & 4.832 & 248 & & - & 0 & - & & & & - \\
\hline 11 & WBB-1:5 & 5 Riachão & $" 1$ & - & 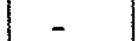 & Or & $08 / 85$ & - & 7,48 & $23,00\}$ & 600 & 39 & - & - & - & 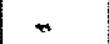 & 5 & & - & - \\
\hline 9 & PT-0I & Lagoa de & Sapé & - & - & Or & $05 / 81$ & 26,00 & $\div$ & - & 2.716 & - & - & - & - & 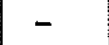 & 9 & & - & 553,4 \\
\hline & $R P A-56$ & Santana & S.Seb & 716,7 & $9.240,3$ & $o_{r}$ & 02782 & 50.00 & 3.26 & 17,25 & 3.278 & 234 & ito & Arg.ar. & 1,0 & 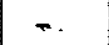 & 5 & & - & 1. \\
\hline 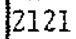 & WRB-85 & Wa Beijada & $"$ & - & - & Or & $08 / 84$ & $50,00\}$ & $12 ; 80$ & 16.49 & 1.636 & 443 & Gna & Ar. & 1, & 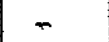 & 8,4 & & - & 815,0 \\
\hline & -86 & Deserto & $" *$ & - & - & or & 0 & & & & 60 & 106 & & $\mathrm{Si}$ & 1 & & & & - & \\
\hline & 87 & Sede I & " " " & $m$ & - & Or & 84 & 0 & 3 & 49 & 5.142 & 620 & ' & Sil & 3 & & 4 & & - & 312,0 \\
\hline & -209 & 9. Sede II & " $"$ & 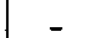 & - & Or & 0 & & 4. & 10 & 26 & 90 & ' & Ar. & 3 & 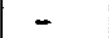 & & & - & 9.0 \\
\hline & -33 & Santa Luzia & " " & 709,5 & $9.102,5$ & $O_{x}$ & 6 & 50 & 3 & & 1.800 & 94 & ' & Ar & 3 & - & & & - & 3,4 \\
\hline o & RPA-34 & No Beijada & $" n$ & 718,3 & 1,1 & $0 x$ & $09 / 81$ & 43,00 & 3,00 & 18 & 1.200 & 63 & , & Arg.silt & 1, & +2 & , 8 & & - & 75,7 \\
\hline 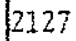 & $|R P W-09|$ & Santa Lu: & Serra Brance & 773,0 & 9.7 & or & 0 & 50 & 4,35 & 7 & 13 & 98 & & $" 1$ & 1, & _ & & & - & \\
\hline & $R P A-25$ & Cacjuba & $"$ & $740^{\circ}$ & & Or & 68 & & 2,90 & 6, & 1.285 & 420 & & $"$ & 6,0 & a & 38,7 & & - & \\
\hline 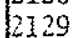 & -26 & Salo & $"$ & 745,7 & 19 & Or & & & 1,87 & 5,25 & 2.769 & 819 & & Are & 3 & 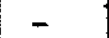 & & & - & \\
\hline & -62 & Lige & $"$ & 748,9 & & Or & & & 3,97 & 6 & 10 & 5.000 & ' & & 1 & - & & & - & 367,5 \\
\hline & 260 & San & $"$ & 762 & & or & & & 3,70 & {$[13,0]$} & 38 & 590. & ' &. $\mathrm{ag}$ & 3 & 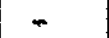 & & & 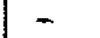 & 380,0 \\
\hline & & Agr & $"$ & & & $0 x$ & & & $I, 53$ & & & 60 & " & & 3 & 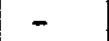 & & & & \\
\hline & 74 & Sit & $"$ & 761,2 & 9.17 & Or & 6 & 4 & 10, & 13 & 6. & 508 & " & & 3 & & & & & 70,0 \\
\hline t & WBB-6S & Sem & Serra Redonda & - & - & Or & 0 & 50 & 8,67 & 13 & 1.558 & 304 & ' & $\operatorname{Arg}$ & 1 & & & & $\tau$ & \\
\hline & RPUB-C5 & Bar & Serraria & - & & or & & & 4 & & 55 & 133 & $"$ & $r$. & 3 & - & & & - & $7 t, 9$ \\
\hline 5 & RPS-10 & Card & Sumé & 597,0 & $9.243,5$ & $\int_{\pi}$ & bi & 50 & 2,60 & 5 & 2.727 & 1.103 & $\mathrm{Mi}$ & Arg & 3 & & & & - & \\
\hline & $\left|R P P_{1}-11\right|$ & & & 721 & & lor & & & & & & 389 & & & 4 & 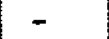 & & & - & \\
\hline & $\mathrm{R}$ & jun & & 720 & & Or & 68 & & 2 & & 7.9 & 946 & & it. & 3, & & & & - & \\
\hline & $R$ & & & 734,7 & & or & & & 6,60 & & 10 & 359 & & & 3 & 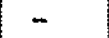 & & & - & \\
\hline & & La & " & 720,1 & & Or & & & & & 14 & 276 & & Ar. & 1 & - & & & $=$ & \\
\hline & $R P$ & Cìna & & 718,2 & & $0 x$ & p7 & & 3,00 & 9 , & 343 & 62 & & $"$ & 1,0 & & & & - & \\
\hline & & & " & & & $\operatorname{los}_{x}$ & & & & & & $-7+2+2>$ & $\mu$ & 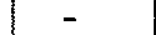 & 0 & & & & - & \\
\hline & & $s_{i}^{3}$ & & 738 & 9.1 & 1 & $p$ & & 3. & & 2.637 & 187 & & _. & 0 & - & & & - & 4,0 \\
\hline & & Capo & Tacima & - & - & br & $05 / 82$ & 0 & 3,95 & {$[12,69$} & 92 & 10 & & Arg.Ar. & 1,0 & 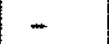 & 14 & & - & \\
\hline & & & Taperoá & 736 & & OT & & & 7 . & & 765 & 45 & & & 3, & & & & & \\
\hline & & & & 72 & & & 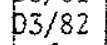 & & 3 & & 2.181 & 274 & Gna & & 1,0 & & 10 & & & \\
\hline & & Co: & $T:=$ & 723,6 & 9.19 & for & & & 6,18 & 24,48 & 585 & 31 & H 10 & Ar. & 3,0 & Ag. & 32 & & $"$ & \\
\hline & & & & - & & or & bs & $40,00\}$ & 1,82 & 11,98 & 1.039 & 138 & & & 0 & & & & & \\
\hline 634 & & Sitio & Agua Bra & & & $b c$ & $\mathrm{p} 1 / 84$ & 60,00 & 8,36 & {$[12,82$} & 59 & 13 & se & it. & 6,0 & - & 13 & & - & \\
\hline 6150 & $A 0^{2}$ & Sitio & $"$ & 63 & & be & DIJ & & 2,90 & & 1.220 & 109 & & Ar & 3 & - & & : & - & 50 \\
\hline E151 & & tajes & Aguiar & 88,9 & & & & & 5,80 & 10,21 & 128 & 29 & & & & & & & & \\
\hline
\end{tabular}


CADASTRO GERAL DOS POCOS PERFURADOS NOS ESTADOS DO RIO GRANOE DO NORTE E PARAIBA

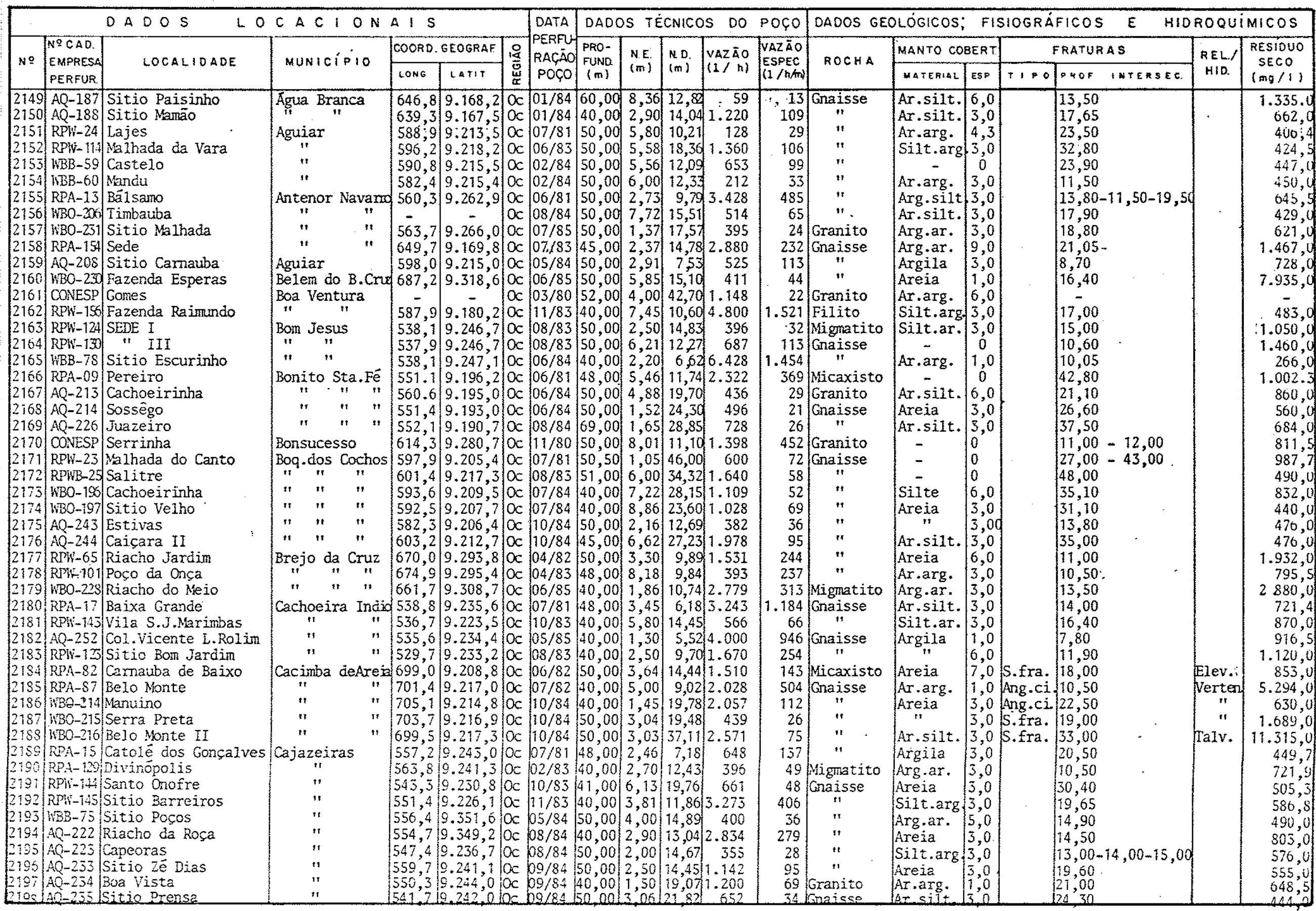


CADASTRO GERAL DOS POCOS PERFURADOS NOS ESTADOS DO RIO GRANDE DONORTE E PARAIBA

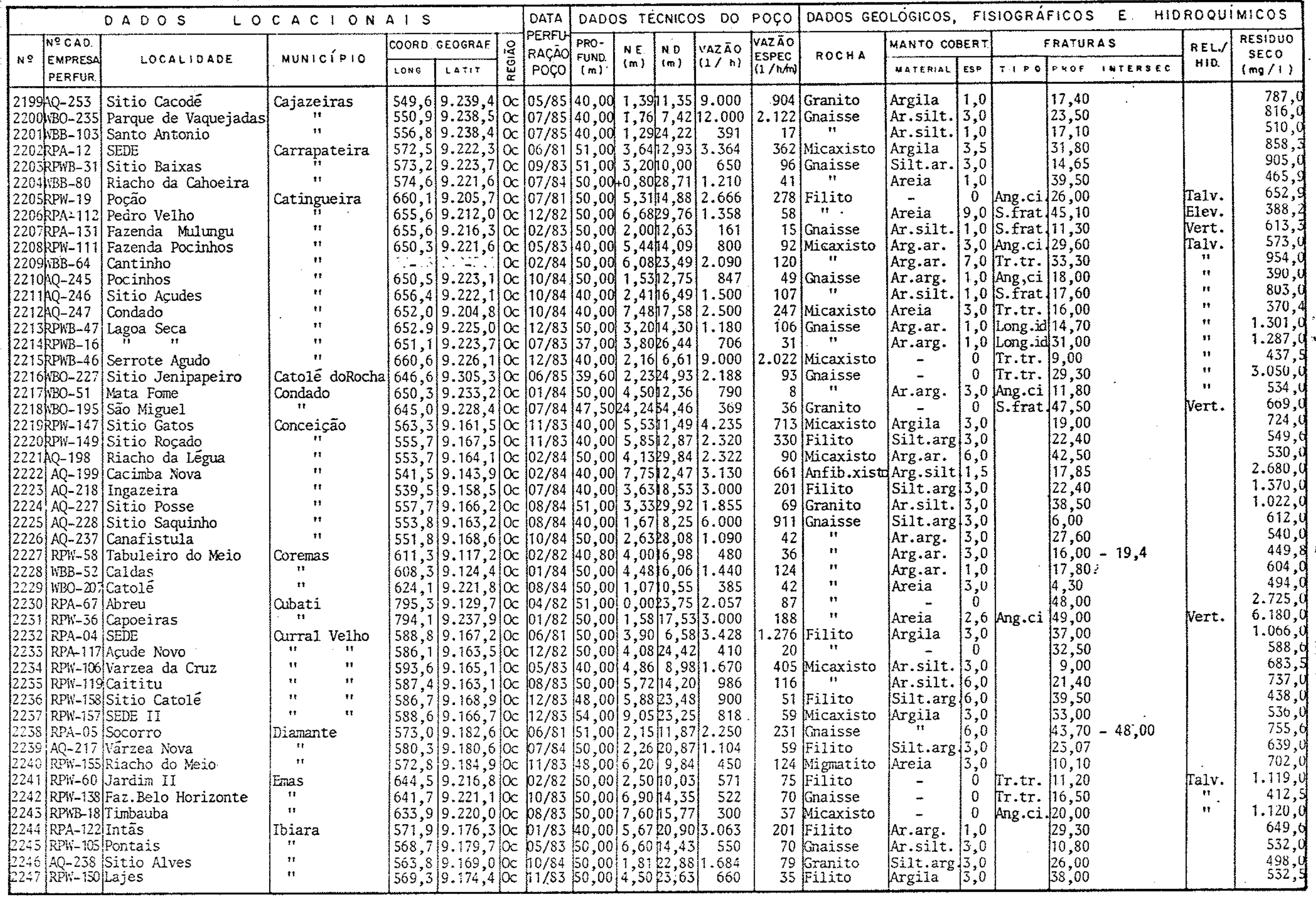


CADASTRO GERAL DOS POÇOS PERFURADOS NOS ESTADOS DO RIO GRANDE DONORTE E PARAIBA

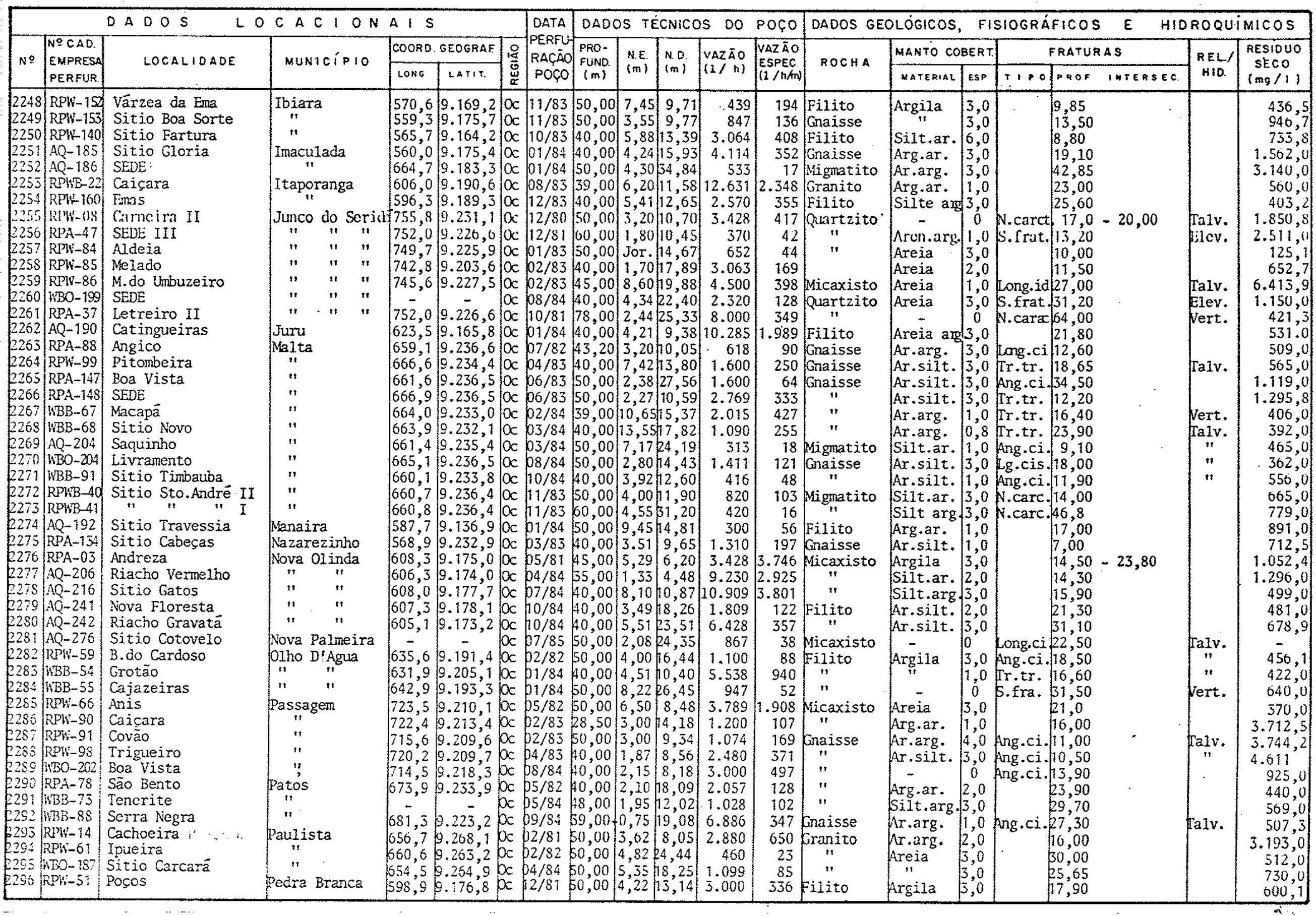


CADASTRO GERAL DOS POCOS PERFURADOS NOS ESTADOS DO RIO GRANDE DONORTE E PARAIBA

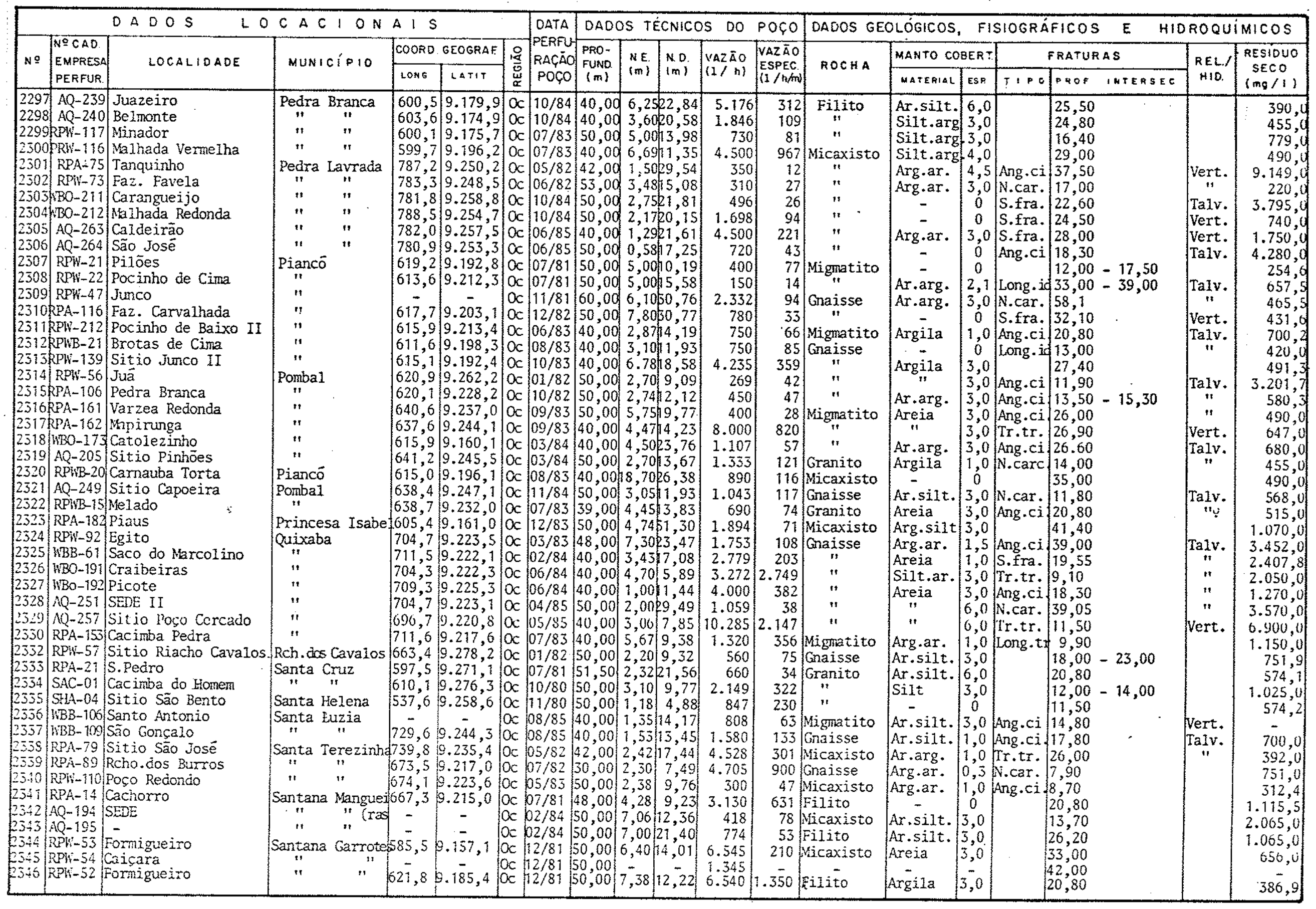


CADASTRO GERAL DOS POÇOS PERFURADOS NOS ESTADOS DO RIO GRANDE DONORTE E PARAIBA

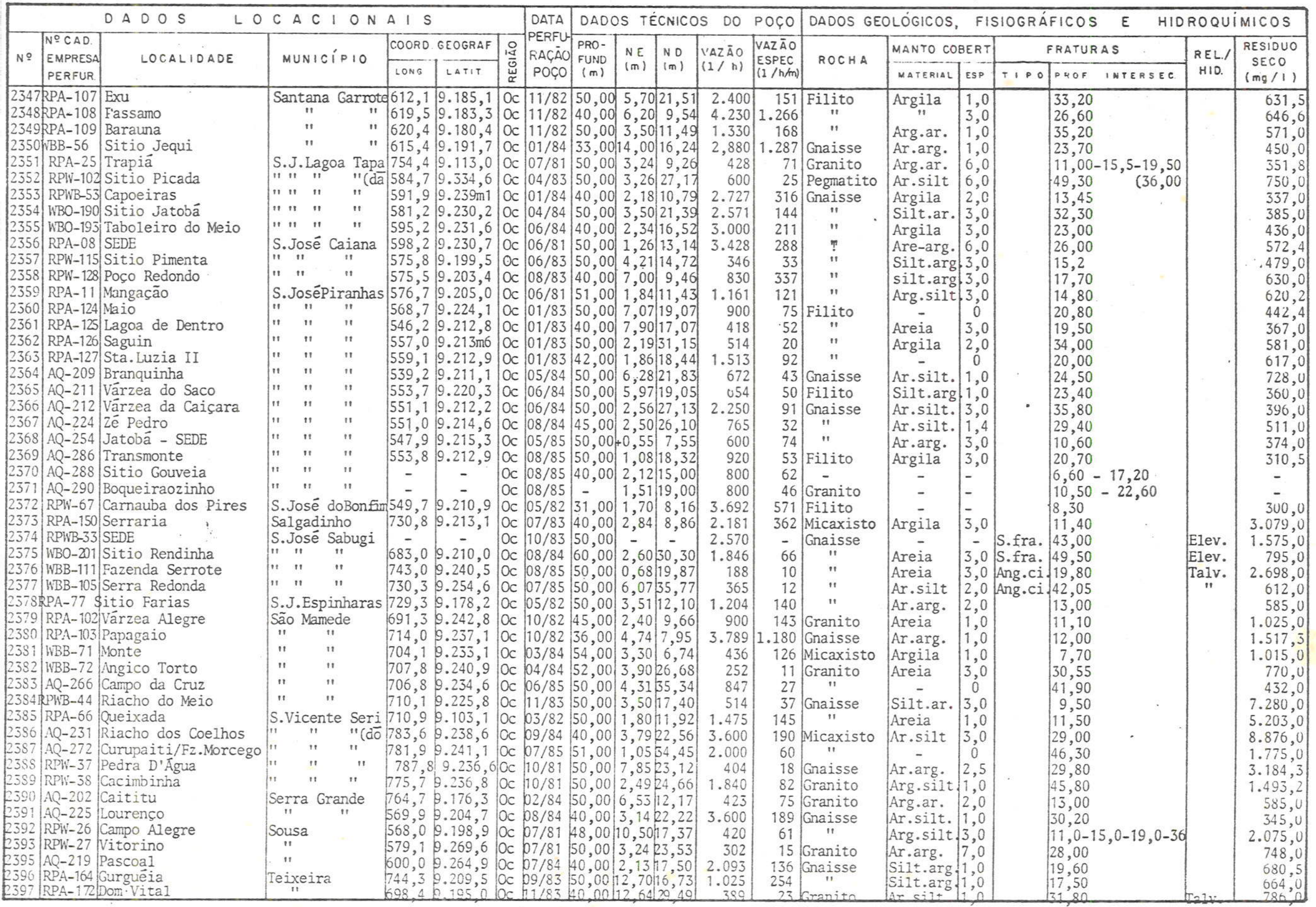


CADASTRO GERAL DOS POÇOS PERFURADOS NOS ESTADOS DO RIO GRANDE DO NORTE E PARAIBA

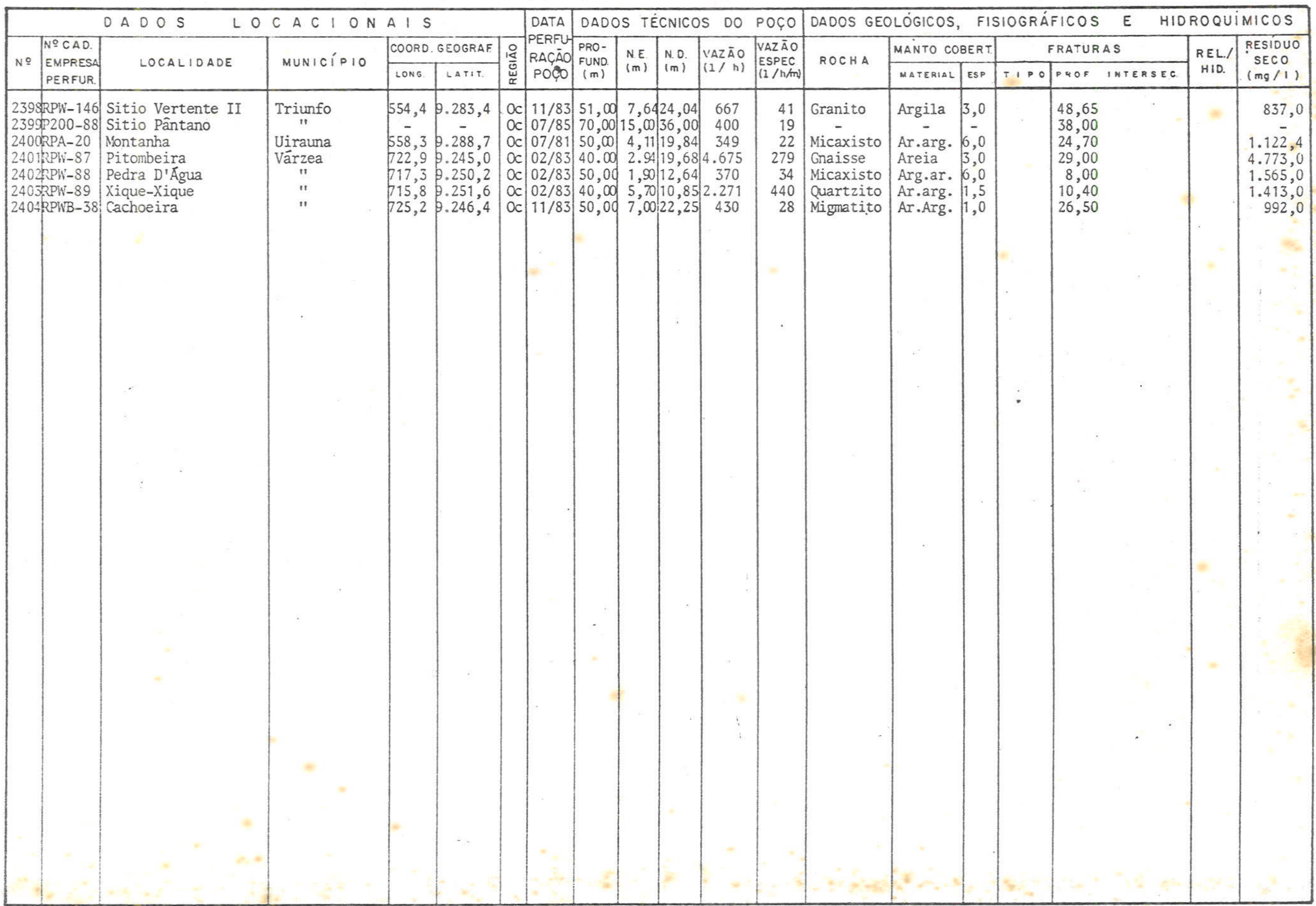





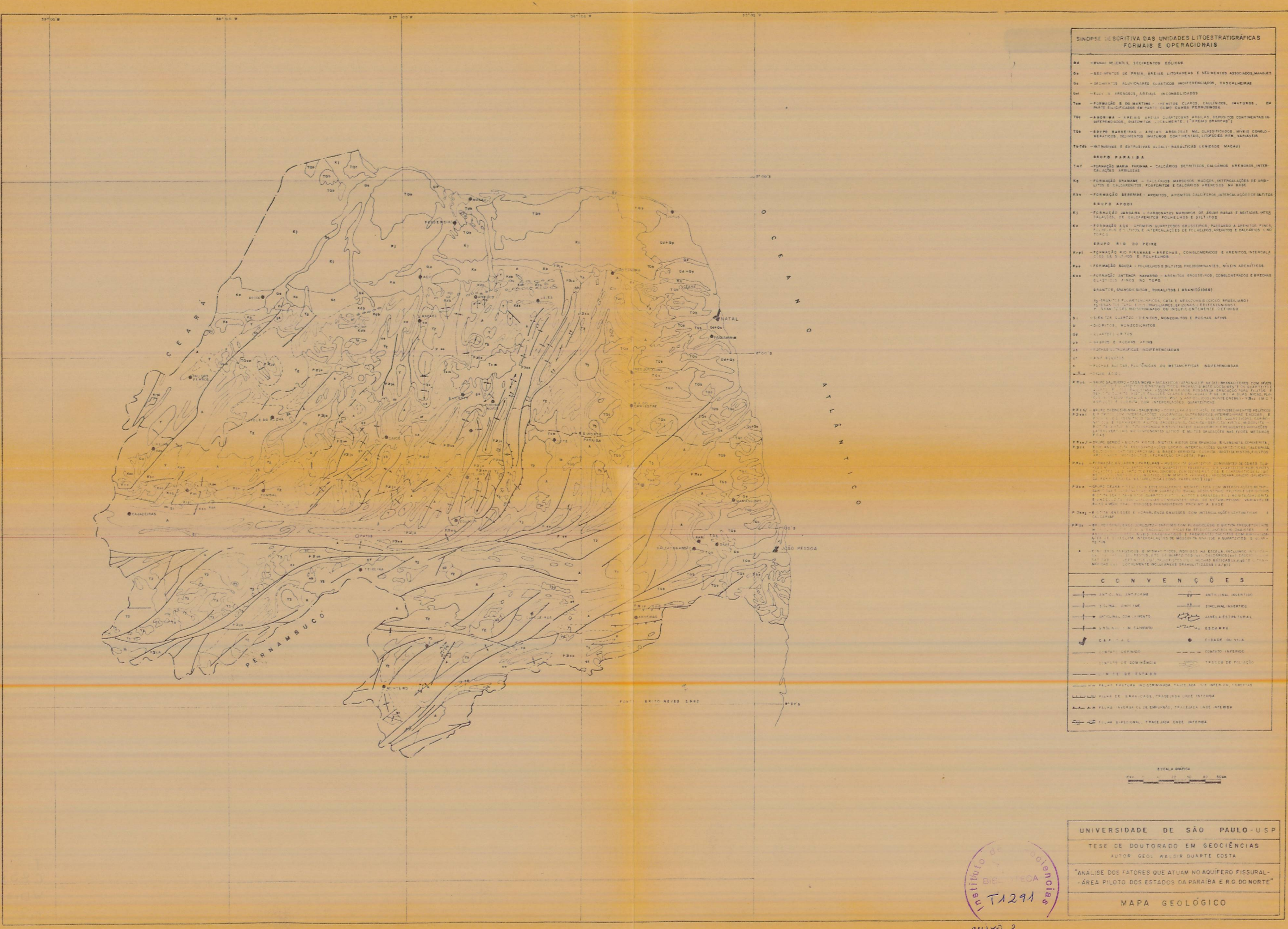

